\title{
Shenoute, Besa and the Bible
}

Digital Text Reuse Analysis of Selected Monastic Writings from Egypt

Dissertation zur Erlangung des philosophischen Doktorgrades

\author{
vorgelegt von So Miyagawa \\ aus Kobe
}

Göttingen 2021

1. Gutachterin: Prof. Dr. Heike Behlmer

2. Gutachter: Dr. Frank Feder

3. Gutachterin: Apl. Prof. Dr. Heike Sternberg-El Hotabi 
Hiermit versichere ich an Eides statt, dass ich die schriftliche wissenschaftliche Abhandlung (Dissertation) selbstständig verfasst und keine anderen als die angegebenen Quellen und Hilfsmittel benutzt habe und dass anderweitig keine entsprechende Promotion beantragt wurde und hierbei die eingereichte Dissertation oder Teile daraus vorgelegt worden sind.

Des Weiteren erkläre ich hiermit, dass diese digitale Fassung mit der schriftlichen wissenschaftlichen Abhandlung (Dissertation) übereinstimmt. 



\section{Abstract}

This study sees itself as part of the larger field of intertextuality studies and examines, using the latest digital text reuse technology, the reuse of biblical texts in the writings of two Late Antique Christian authors from Egypt, the abbots Shenoute and Besa. It explores, on the basis of selected writings by these authors, the advantages and limitations of using digital methods to study the form and function of biblical intertexts in monastic literature written in Coptic. In particular, it seeks answers to a number of specific research questions, e.g., the extent to which quotations are faithful to the original biblical sources, the influence of quotation-introducing formulae or the question how digital technologies can be used to facilitate intertextuality studies.

To pursue these topics, after an introduction to the life and works of both authors (Chapter 1), it describes the state of research for intertextuality studies with a focus on biblical and Early Christian and Coptic studies, and Shenoute in particular (Chapter 2). Text reuse detection technology, which was developed in the field of computer science, is introduced, and its practical applications are described. Specific focus is placed on the history of text reuse detection and the subtle differences between intertextuality and text reuses. In addition, the current progress in studies on intertextuality in Shenoute's works is explored.

Digital text reuse technology is described in detail (Chapter 3), in particular the technology that underpins the processing mechanisms employed by the latest text reuse detection software, TRACER, and pre-processing features such as optical character recognition, Unicode conversion, tokenization, lemmatization, and part-of-speech tagging. The case study for examining the application of digital text 
reuse technology has to focus on a limited selection of biblical texts, and specifically, on the best attested and most well-known book of the Old Testament, the Book of Psalms. Chapter 4 presents the philological and codicological information on the corpora used, the Sahidic translation of the Psalms, and the selected works by Shenoute and Besa, while Chapter 5 is dedicated to the case study and its results. It analyzes text reuses newly identified by TRACER, discusses instances of idiomatic text reuse and the question of quotation-introducing signals.

In summary, this study confirms observations by previous research that the monastic authors built on the audience's collective memory of the Bible by blending biblical phrases and concepts with their own monastic ideals. For the purpose of recontextualizing the source texts and fitting them to the current situation, unmarked changes may be applied, mostly of a grammatical nature. An interesting difference between the two monastic authors may be noted in their use of quotation-introducing signals, which merits further exploration, as does the question of the relation between the introduction of a quotation and its faithfulness. Finally, it needs to be stressed that ongoing and future digitization of the corpus of monastic authors and Coptic literature in general will very much widen the scope of digital text reuse methods and lead to new research questions and discoveries. 


\section{Zusammenfassung}

Die vorliegende Studie versteht sich als Teil des weiteren Feldes

„Intertextualitätsforschung“ und untersucht mit Hilfe neuester digitaler „Text Reuse“-Technologie die

Wiederverwendung biblischer Texte in den Schriften zweier spätantiker christlicher Autoren aus

Ägypten, der Äbte Schenute und Besa. Anhand ausgewählter Schriften dieser Autoren werden die

Vorteile und Grenzen des Einsatzes digitaler Methoden zur Untersuchung von Form und Funktion

biblischer Intertexte in der koptischen Mönchsliteratur untersucht. Insbesondere wird nach Antworten

auf eine Reihe spezifischer Forschungsfragen gesucht, z.B. inwieweit Zitate die biblischen

Originalquellen getreu wiedergeben, welchen Einfluss zitateinleitende Formeln haben oder wie digitale

Technologien im Bereich der Intertextualitätsforschung genutzt werden können.

Um diesen Themen nachzugehen, wird nach einer Einführung in Leben und Werk der beiden Autoren (Kapitel 1) der Forschungsstand zur Intertextualitätsforschung mit dem Schwerpunkt Bibel und Frühchristentum sowie Koptologie und insbesondere Schenute beschrieben (Kapitel 2). Die in der Informatik entwickelte Technologie zur Erkennung von Textwiederverwendung wird vorgestellt und ihre praktische Anwendung beschrieben. Besonderes Augenmerk wird auf die Geschichte der Erkennung von Wiederverwendungen und die feinen Unterschiede zwischen Intertextualität und Textwiederverwendung gelegt. Darüber hinaus wird der aktuelle Stand der Forschung zu Intertextualität in Schenutes Werken untersucht.

Die Methoden der digitalen „Text Reuse“-Forschung werden ausführlich beschrieben (Kapitel 3), insbesondere die Technologie, die den Verarbeitungsmechanismen zugrunde liegt, die von der neuesten Software zur Erkennung von Textwiederverwendung, TRACER, eingesetzt werden, sowie 
„pre-processing“--Funktionen wie optische Zeichenerkennung, Unicode-Konvertierung, Tokenisierung, Lemmatisierung und Part-of-Speech-Tagging. Die hier vorgelegte Fallstudie zur Untersuchung der Anwendung digitaler „Text Reuse“-Technologie muss sich auf eine begrenzte Auswahl biblischer Texte konzentrieren, und zwar auf das am besten bezeugte und bekannteste Buch des Alten Testaments, die Psalmen. In Kapitel 4 werden die philologischen und kodikologischen Informationen zu den verwendeten Korpora, die sahidische Übersetzung der Psalmen und die ausgewählten Werke Schenutes und Besas, vorgestellt, während Kapitel 5 der Fallstudie und ihren Ergebnissen gewidmet ist. Es analysiert die von TRACER neu identifizierten Textwiederverwendungen, erörtert Fälle von idiomatischer Wiederverwendung und die Frage der zitateinleitenden Signale.

Zusammenfassend bestätigt diese Studie die Beobachtungen früherer Forschungen, dass die monastischen Autoren auf dem kollektiven Gedächtnis des Publikums an die Bibel aufbauten, indem sie biblische Phrasen und Konzepte ihren eigenen klösterlichen Idealen vermischten. Um die Quellentexte zu rekontextualisieren und sie an die aktuelle Situation anzupassen, können unmarkierte Änderungen vorgenommen werden, die meist grammatikalischer Natur sind. Ein interessanter Unterschied zwischen den beiden monastischen Autoren besteht in ihrer Verwendung von Formeln, die ein Zitat einleiten, was eine weitere Untersuchung verdient, ebenso wie die Frage nach dem Zusammenhang zwischen der Einleitung eines Zitats und seiner Zitatentreue. Abschließend ist zu betonen, dass die laufende und künftige Digitalisierung des Korpus der monastischen Autoren und der koptischen Literatur im Allgemeinen den Anwendungsbereich der Methoden der digitalen „Text Reuse"-Forschung erheblich erweitern und zu neuen Forschungsfragen und Entdeckungen führen wird. 



\title{
EחNEYMd NTE חIEIOT
}

\section{Waga chichi no rei ni}

\author{
"For the spirit of my father"
}

From the dedication page of Koputogo Shōbunten [JPN: Concise Grammar of Coptic Language]

by Seitarō Okajima, the first Coptic grammar written in Japanese (Okajima 1942) 


\section{Preface}

It has taken me nearly six years to complete this dissertation. Over this time, I spent four and a half years in Göttingen, over a month in Jerusalem, three weeks in Leipzig, and over a week each in Washington, D.C.; London; Oslo; Lund; Athens; Leiden; Cairo; and more. I had often dreamed of traveling and meeting new people and learning new things, so it was exhilarating to be finally able to take these trips. As I left my native Japan and encountered new experiences, I grew even more curious, and my dedication to research was repeatedly renewed. However, the abundance of new knowledge was sometimes overwhelming, and it was important to follow the advice of my mentors and focus on my area of study. While I was improving my focus and discovering a productive path for my research, COVID-19, an employment opportunity, and concerns about my mother — who lives alone — brought me back to Japan. There, I spent a year in Osaka and a year in Kyoto, where I focused on my job and home life.

When I returned to my research notes and memos to organize five years of work from my time in Europe and beyond, I was finally able to identify a suitable structure for my project. Working under the invaluable supervision of Prof. Heike Behlmer and my co-supervisor, Dr. Frank Feder, I finally completed my dissertation. I could not have made such progress without their patient guidance and input. In particular, Prof. Behlmer's expertise on Shenoute and Besa and Dr. Feder's scholarly work on the Coptic Bible were tremendously helpful.

In addition to my supervisors, I also wish to thank the members of the Digital Edition of the Coptic Old Testament (CoptOT) project at the Göttingen Academy of Sciences and Humanities, Dr. 
Diliana Atanassova, Dr. Troy Griffitts, Dr. Suzana Hodak, Joanna Hypszer, Theresa Kohl, Dr. Chrysi Kotsifou, Dr. Uwe-Carsten Plisch, Malte Rosenau, Prof. Ulrich Schmid, Dr. Nina Speransky, Dr. Alin Suciu, and - last but not least - my Sonderforschungsbreich (SFB) 1136 project partner and best friend, Julien Delhez. In particular, the insights provided by Dr. Atanassova, Dr. Suciu, Dr. Kotsifou, Prof. Schmid, and Dr. Griffitts proved essential for my project, as did their feedback on my previous papers and their generous provision of references and manuscript photos.

Additionally, I wish to express my gratitude to Deutsche Forschungsgemeinschaft (DFG) and the collaborative research center SFB1136 "Education and Religion in Cultures of the Mediterranean and Its Environment from Ancient to Medieval Times and to the Classical Islam" for the academic and financial support that they provided to help me complete this dissertation. The members of SFB1136including the director, Prof. Peter Gemeinhardt; the project area leader, Prof. Florian Wilk; Sofia Fomicheva; Ulrike Schwartau; Dr. Maria Munkholt Christensen; Dr. Jennifer Singletary; Christoph Winkler; Dr. Dmitry Bumazhnov; Dr. Chiara Meccariello; Dr. Levke Bittlinger; Dr. Karin Gottschalk; and many others - always encouraged me and stimulated my curiosity about religion and education studies, which helped me advance as a researcher.

I wish to acknowledge many other people who made contributions to my dissertation. Firstly, at the Seminar for Egyptology and Coptic Studies, Prof. Heike Sternberg-El Hotabi offered great support in all aspects of my life and studies in Göttingen and taught me a vast amount about the field of Egyptology. Secondly, Prof. Camilla Di Biase-Dyson gave me abundant and valuable career advice and guidance on how to structure my dissertation. In addition, Naoko and Waldemar Wolze, Dr. Janne ArpNeumann, Orell Witthuhn, Anne Wolff, Nina Wagenknecht, Alberto Winterberg, Dr. Mona Sawy, and Natalia Kruglova always gave me a warm welcome at the Bibliotheca Aegyptiaca. Moreover, Ali 
Langroudi, a specialist in Iranian Studies, kept his office door open for scintillating conversations on Christianity in the Orient. Put simply, I could not have completed my dissertation without my colleagues and mentors at the Seminar for Egyptology and Coptic Studies, SFB1136, and CoptOT.

Seven years ago, before I made the decision to major in Coptic studies, I was studying historical linguistics at Kyoto University and was a student of Ancient Greek, Latin, Sanskrit, Avestan, Old Irish, Tocharian, and more. I was also teaching myself Ancient Egyptian or Coptic, the language with the longest written tradition. This was inspired by my interest in the changes that occurred in this language over time. My passion for the history of Ancient Egyptian and Coptic grew, but Japan provided limited opportunities for me to study this topic, as it was not a popular area of investigation in my country. Unsure about how to proceed, I sought out the supervisor for my master's thesis, Prof. Yutaka Yoshida, for suggestions. He said that, to become an expert in Coptic, I had to study in Europe. This sentiment was echoed by Prof. Richard Jasnow, a highly respected Egyptologist from Johns Hopkins University who visited Japan to examine the Demotic papyri of Tokai University's Suzuki Collection in 2014. Eager to act on the professors' advice, I attended a seminar on Coptic studies in Barcelona and a summer course in Egyptology at University College London. These experiences piqued my interest in papyrology. Based on what I learned, I also developed a fascination with early monasticism in Egypt and religious diversity in Late Antiquity.

Japan is a largely non-religious nation that is not affiliated with any particular faith, although festivals and rituals related to Shinto and Mahayana Buddhism are widespread, as they are part of Japanese tradition. Monotheistic Abrahamic religions, by contrast, are considered exotic and have always held an allure for me. I was especially interested in the history of these religions in the Middle East, the birthplace of the three Abrahamic faiths. With its complicated and diverse religious history, 
Egypt formed the nexus of my fascination. However, it was not until 2014 that I first encountered Coptic studies at the International Seminar for Coptic Papyrology. I took courses led by Dr. Anne Boud'hors, Prof. Sofía Torallas Tovar, Prof. Tonio Sebastian Richter, Prof. Alan Delattre, Dr. Naïm Vanthieghem, Dr. Nathan Carlig, Dr. Esther Garel, and Dr. María Jesús Albarran Martínez. I also had the chance to meet accomplished researchers such as Dr. Renate Dekker, Dr. Johanna Stolk, Julien Delhez, Prof. Barbara Egedi, Dr. Katharina Schröder, and Prof. Marina Escolano-Poveda. I would like to specially thank the two Coptic scholars who wrote recommendation letters for me: Profs. Satoshi Toda and Jacques van der Vliet.

In 2015, I attended a workshop entitled "Digital Coptic 2" in Washington, D.C., which introduced me to the potential of applying digital humanities to the field of Coptic studies. I enjoyed discussions with the esteemed Prof. Caroline T. Schroeder, Prof. Amir Zeldes, Dr. Feder, Prof. Melissa Harl Sellew, Prof. Janet Timbie, and Dr. Frederic Krueger. Profs. Schroeder and Zeldes are two of the lead researchers of the exciting Coptic SCRIPTORIUM project and had enthusiastically welcomed me into it the previous year. Since then, we have closely collaborated on the KELLIA and SFB1136 projects. Profs. Schroeder and Zeldes have always been happy to offer useful guidance on Coptic studies, computational linguistics, and the career opportunities open to doctoral students. In 2017, I was lucky enough to be reunited with Profs. Zeldes and Timbie, who made my week-long stay in Washington D.C. a motivating and productive one.

In Leipzig, I joined the DDGLC project, where I was hosted by Joost Hagen, Vincent Walter, Dr. Frederic Krueger, and Profs. Tonio Sebastian Richter and Dylan Burns. We worked together for a very busy and productive month before the headquarters for the project were moved to Berlin. I also visited Israel three times to work with Halely Harel and Profs. Orly Goldwasser and Eitan Grossman at 
the Hebrew University of Jerusalem. Prof. Grossman was instrumental in enabling me to remain in Israel for a full month that spanned 2018 and 2019 . He also gave me the opportunity to conduct research in Jerusalem for a full year starting from July 2020, but the COVID-19 outbreak forced me to rethink my plans and return to Japan to be with my mother. However, I am indebted to Prof. Grossman for his support. Moreover, while in Israel, I was invited to participate in the promotion of the digital humanities in Israel by Dr. Sinai Rusinek, Dr. Yael Netzer and Prof. Jonathan Ben-Dov.

In Sweden, at the University of Lund, I had the good fortune to be welcomed by Prof. Samuel Rubenson, Dr. Paul Linjamaa, Dr. Britt Dahlman, and Dr. Elisabet Göransson and her family during a research trip to explore Egyptian monasticism. Later, I was able to work at the Egyptian Museum and Papyrus Collection in Berlin thanks to Prof. Verena Lepper, who has been very supportive of my professional ambitions. During my stay in Oslo, I was supported by Lloyd and Kei Abercrombie, with whom I was reunited during their stay in Göttingen. Additionally, a digital curator of the British Library, Dr. Rossitza Atanassova, kindly invited me to lecture at the library. She educated me about the current status of the Coptic manuscripts at the British Library, which are managed under the guidance of Dr. Ilana Tahan. In addition, during my travels, I learned a great deal from Prof. Hugo Lundhaug, Prof. Tito Orlandi, Prof. Paola Buzi, Prof. René Falkenberg, Prof. Nils Arne Pedersen, Dr. Chris Reintges, Prof. Ruth Kramer, and Prof. Siegfried Richter. Moreover, my dissertation has directly benefited from the research and input of Prof. Stephen Emmel. Furthermore, Dr. Eliese-Sophia Lincke, Prof. Franziska Naether, Prof. Daniel Werning, Dr. Gaële Chantrain, Dr. Marwan Kilani, and Prof. Jean Winand have provided important advice on my dissertation and career.

In Göttingen, where I spent the bulk of my time, I received support from many quarters, not least the friends and fathers of the Sankt Michael Church, most notably Dr. Max and Elisabeth Teubner 
and Pater Schneider. I also extend special thanks to Cantando Praedicare, the Gregorian chant school that invited me to join and sing with them. Moreover, I would like to thank Abounas and a Tamav of the Coptic Orthodox Church who encouraged me to research St. Shenouda the Archimandrite; Bishop Damian of Germany; Fr. Morris and Fr. Sharobim from Sydney, Australia; Fr. Philemon and Fr. Maximous from St. Anthony's Monastery in Egypt; Fr. Youhanna and Fr. Eirenaios in Athens; Fr. Bishoy Lamie in the United States, and Mother Antonia from Melbourne, Australia. I am also grateful to the members of the Sunday Bible Reading Group of the Coptic Orthodox Diocese of Sydney and Affiliated Regions and to Coptic friends in Japan, Mina Tadros, Rosemary Soliman, Thomas Yano, and more for their support. In terms of my spiritual journey throughout this dissertation, I owe particular thanks to Fr. Dennis of the Order of Preachers in Teutonia, Pater Martin at the École Biblique et Archéologique Française de Jérusalem, and the pilgrims who accompanied me to Mt. Athos.

Regarding the digital humanities aspect of my studies, I could not have completed my dissertation without collaborating with the eTRAP team, especially Dr. Marco Büchler, Dr. Greta Franzini, Emily Franzini, Dr. Maria Moritz, and Kirill Bulert. In addition, the University of Tokyo's digital humanities research community (UTDH), specifically Dr. Kiyonori Nagasaki, Prof. Ikki Ohmukai, and their colleagues, were a constant source of encouragement as I embarked on my study of digital humanities and taught me about emerging technologies in this field, all of which are rapidly developing and advancing.

In writing this doctoral thesis, Dr. Korshi Dosoo and Justin Yoo proofread the English written by a non-native English speaker. Without their help, this doctoral dissertation would never have been completed. 
My gratitude to Prof. Behlmer extends beyond the purely practical. Persevering with a project over years takes a significant amount of self-discipline and commitment, and I was fortunate to receive suitable advice on how to nurture these qualities from Prof. Behlmer. I also sought insight from books on resilience and mindfulness, which helped me to find the focus and calm required to complete my dissertation. I was particularly influenced by the cognitive techniques presented by Aaron T. Beck in his books and the Pali sutras. Moreover, the serene environment cultivated by Kyoto University and the Kansai University Open Research Center for Asian Studies (KU-ORCAS) and the first-class equipment provided by these institutions helped me to remain focused on and achieve my academic goals.

While I have gained knowledge in the field of Coptic studies, digital humanities, and scholarly life thanks primarily to the many abovementioned people (as well as many others whom I have not named), any errors or shortcomings in my work are mine alone. The primary audience for this dissertation is Coptic scholars, followed by those who work in the digital humanities and are interested in the applications of digital technologies in the study of Early Christianity.

Finally, I would like to thank my parents, Junzo and Fusako Miyagawa, who have provided me with unwavering support throughout my life. Sadly, my father passed away in 2017, but his encouragement of my ambitions to become a researcher will remain with me for the rest of my life. The epigraph to this thesis is taken from the first Coptic grammar textbook to be written in Japanese. Released in 1942 during the Second World War, it was written by Seitarō Okajima, who also lost his father shortly before publishing his work.

Kyoto in the season of the red and yellow leaves, November 12, 2021

So Miyagawa 


\section{Table of Contents}

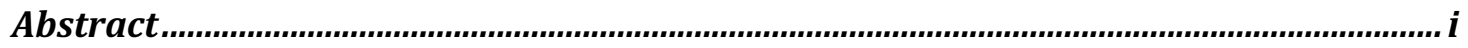

Zusammenfassung

Preface

Table of Contents ............................................................................................................. viii

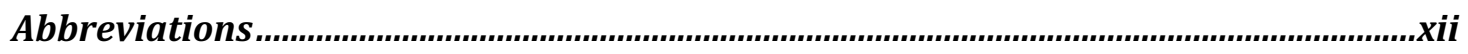

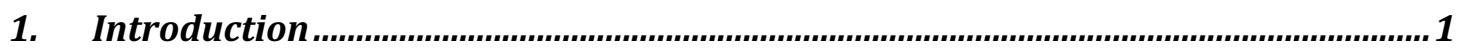

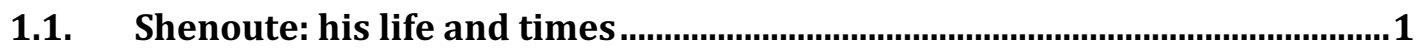

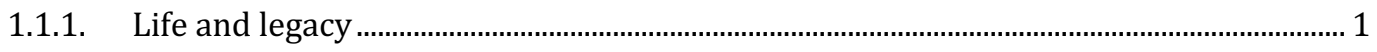

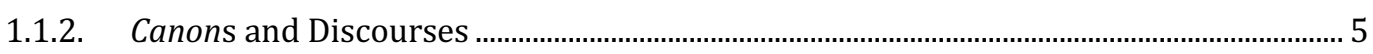

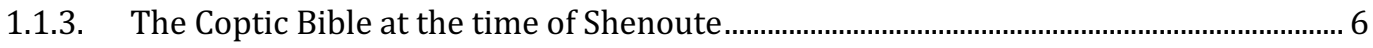

1.1.4. Hellenistic influence on Shenoute........................................................................................15

1.1.5. Appropriation of biblical figures for authority .................................................................19

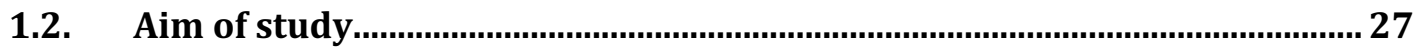

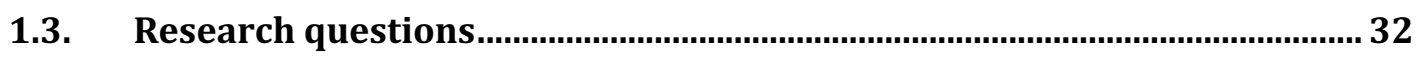

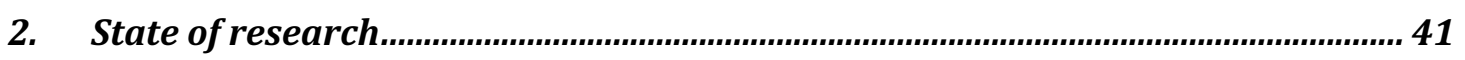

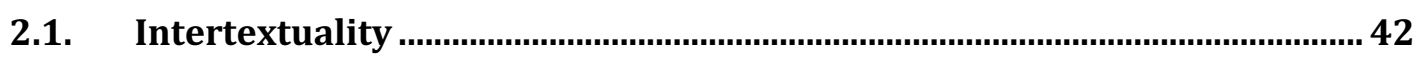

2.1.1. History and concept of intertextuality ……………....................................................... 42

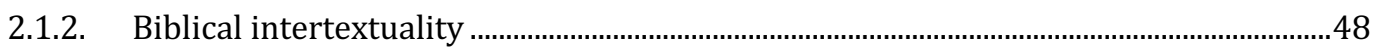

2.1.3. Intertexts from unknown sources …………………...........................................................65

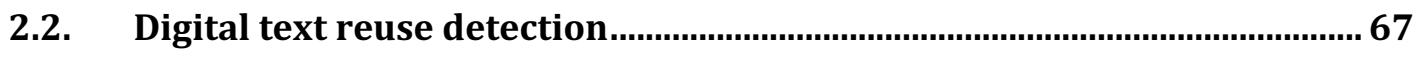

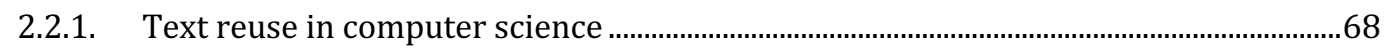

2.2.2. Digital quotation biblical database for patristic literature .................................................78 
2.2.3. Detecting ancient Jewish quotations and allusions with digital tools.

2.3. Tesserae and TRACER

2.4. History of intertext and text reuse representation methods ......................84

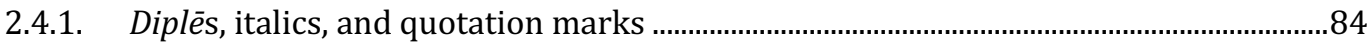

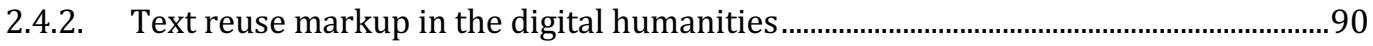

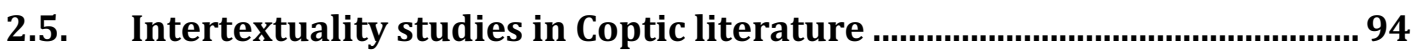

2.6. Linguistic features of text reuses in Shenoute's works ............................100

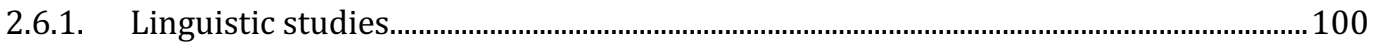

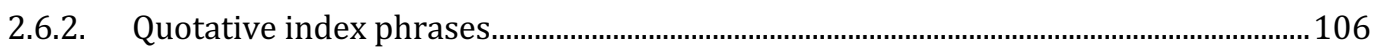

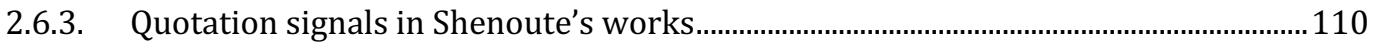

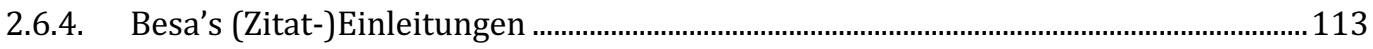

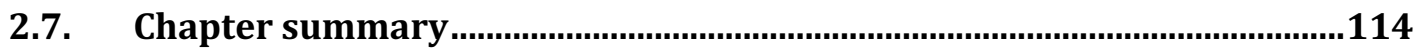

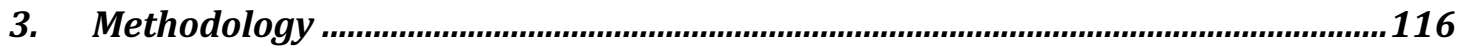

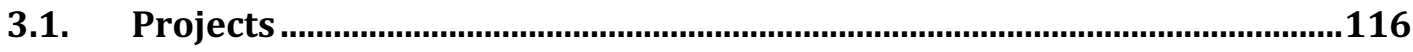

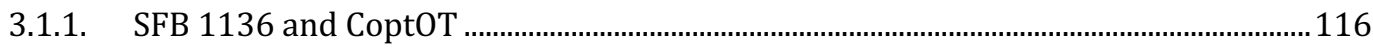

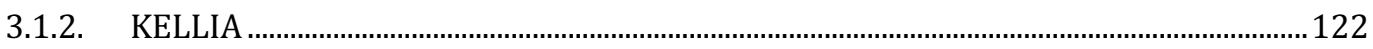

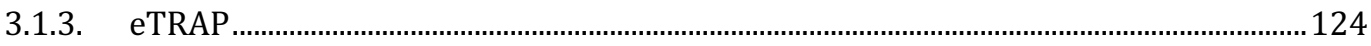

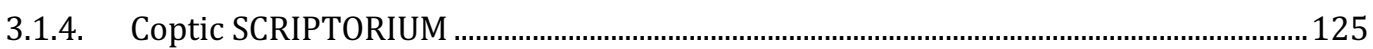

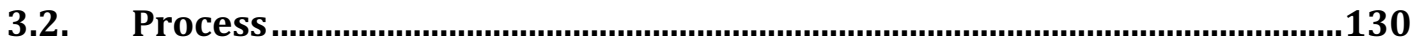

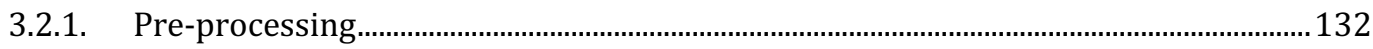

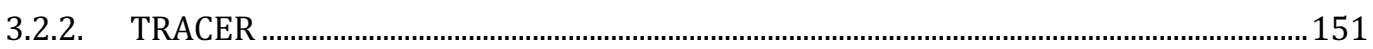

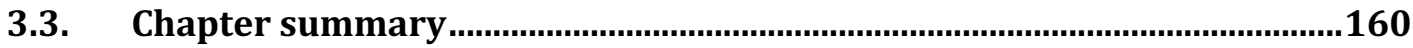

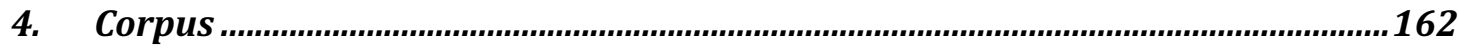

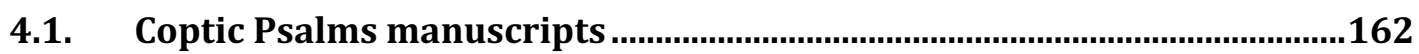

4.2. Shenoute's Canon 6 ...........................................................................................174

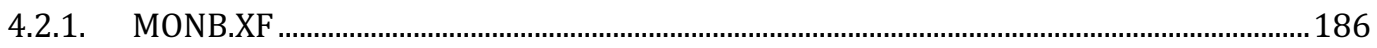




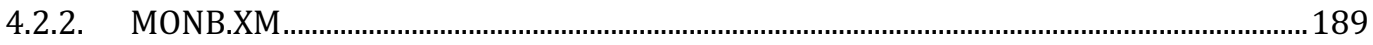

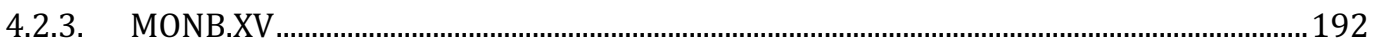

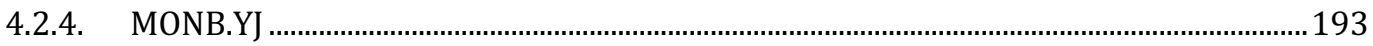

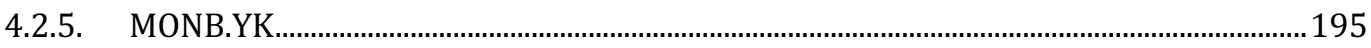

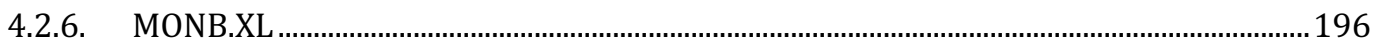

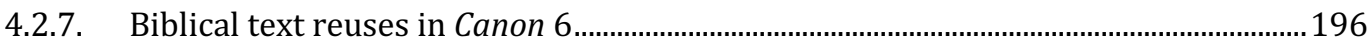

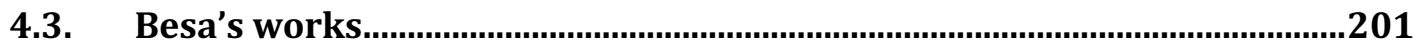

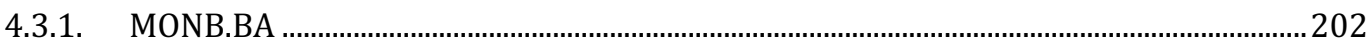

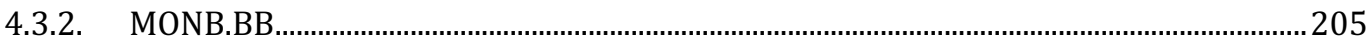

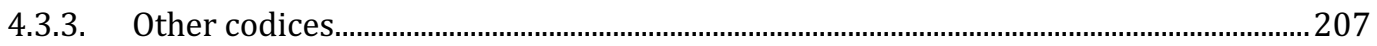

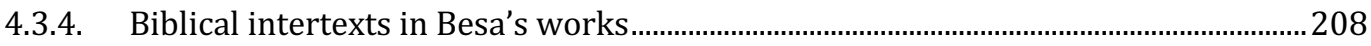

4.4. Chapter summary .....................................................................................215

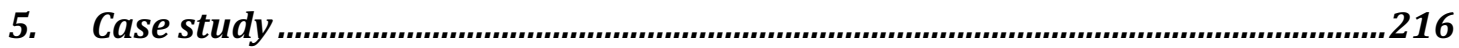

5.1. TRACER results ..........................................................................................217

5.2. Quotations vs. idiomatic text reuses......................................................220

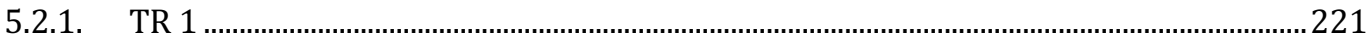

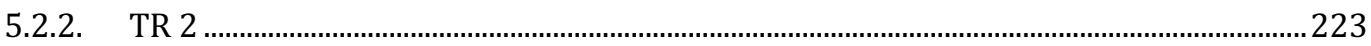

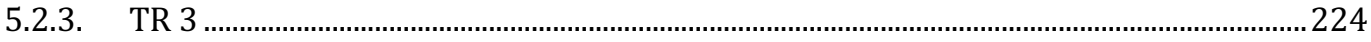

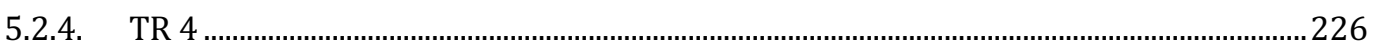

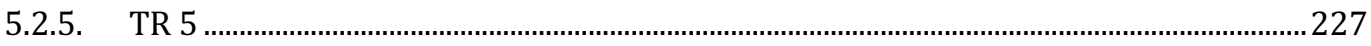

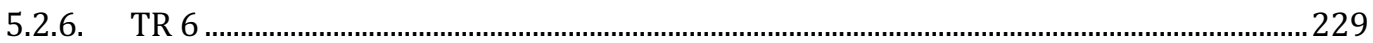

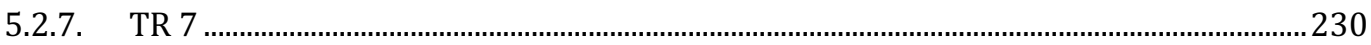

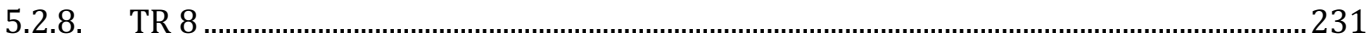

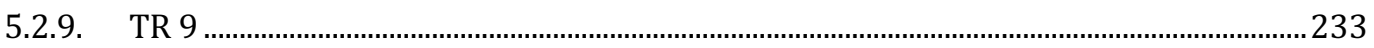

5.2.10. TR 10

5.3. Frequent idiomatic text reuses identified by TRACER ............................237

5.4. Newly identified quotations .............................................................240 
5.4.1. Levenshtein Distance .

5.4.2. New Psalm quotations found in Besa's Letters and Sermons .

5.4.3. Discussion of newly identified Psalms quotations in Besa's Letters and Sermons . 254

5.4.4. New Psalm quotations identified in Shenoute's Canon 6........

5.5. Chapter summary. 279

6. Conclusion and future perspectives... 281

6.1. Research question 1 281

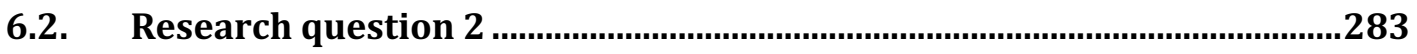

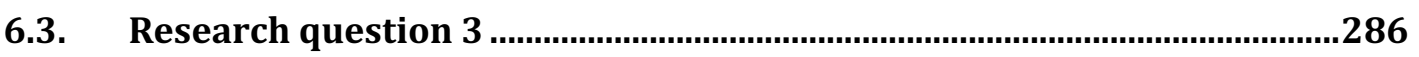

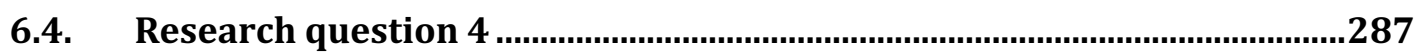

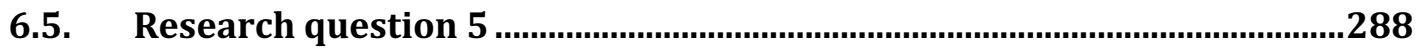

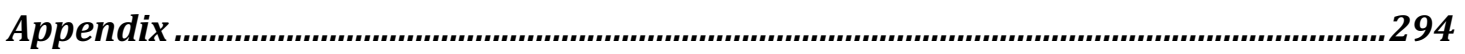

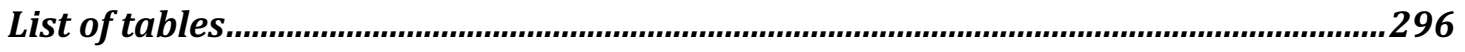

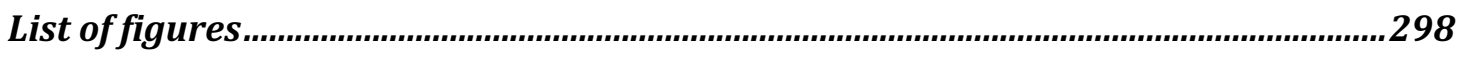

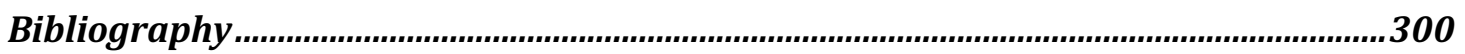




\section{Abbreviations}

\section{$\underline{\text { General terms }}$}

LD = Levenshtein Distance

$\mathrm{QIP}=$ quotative index phrase
$\mathrm{SM}=$ shared morphs

$\mathrm{TR}=$ text reuse

\section{Biblical book titles}

\begin{tabular}{|c|c|c|}
\hline NT $=$ New Testament & Sir $=$ Wisdom of Ben Sira & Rom $=$ Epistle to the Romans \\
\hline OT $=$ Old Testament & Is $=$ Book of Isaiah & 1 Cor $=$ First Epistle to the \\
\hline Gen $=$ Book of Genesis & Jer $=$ Book of Jeremiah & Corinthians \\
\hline Ex $=$ Book of Exodus & Bar $=$ Book of Baruch & 2 Cor $=$ Second Epistle to the \\
\hline Lev $=$ Book of Leviticus & Lam = Book of Lamentations & Corinthians \\
\hline Num $=$ Book of Numbers & EpJer $=$ Epistle of Jeremiah & Gal $=$ Epistle to the Galatians \\
\hline Dtn $=$ Book of Deuteronomy & $\mathrm{Ez}=$ Book of Ezekiel & Eph $=$ Epistle to the Ephesians \\
\hline Jos $=$ Book of Joshua & Sus $=$ Susanna and the Elders & Phil $=$ Epistle to the Philippians \\
\hline Judg $=$ Book of Judges & Dan $=$ Book of Daniel & $\mathrm{Col}=$ Epistle to the Colossians \\
\hline Ruth $=$ Book of Ruth & Bel $=$ Bel and the Dragon & 1 Thes = First Epistle to the \\
\hline $1 \mathrm{Kgdms}=$ First Book of Kingdoms & Hos $=$ Book of Hosea & Thessalonians \\
\hline $2 \mathrm{Kgdms}=$ Second Book of Kingdoms & Joel = Book of Joel & 2 Thes $=$ Second Epistle to the \\
\hline $3 \mathrm{Kgdms}=$ Third Book of Kingdoms & Amos $=$ Book of Amos & Thessalonians \\
\hline $4 \mathrm{Kgdms}=$ Fourth Book of Kingdoms & Oba $=$ Book of Obadiah & 1 Tim $=$ First Epistle to Timothy \\
\hline $1 \mathrm{Chr}=$ First Book of Chronicles & Jona $=$ Book of Jonah & 2 Tim $=$ Second Epistle to \\
\hline $2 \mathrm{Chr}=$ Second Book of Chronicles & Mica $=$ Book of Micah & Timothy \\
\hline
\end{tabular}




\begin{tabular}{|c|c|c|}
\hline 1 Esd $=$ First Book of Esdras & $\mathrm{Nah}=$ Book of Nahum & Tit $=$ Epistle to Titus \\
\hline 2 Esd $=$ Second Book of Esdras & $\mathrm{Hab}=$ Book of Habakkuk & Phil = Epistle to Philemon \\
\hline Esth $=$ Book of Esther & Zeph $=$ Book of Zephaniah & Heb $=$ Epistle to the Hebrews \\
\hline Jud = Book of Judith & Hag = Book of Haggai & Jam = Epistle to James \\
\hline Tob $=$ Book of Tobit & Zech = Book of Zechariah & 1 Pet $=$ First Epistle of Peter \\
\hline Ps $=$ Book of Psalms & Mal = Book of Malachi & 2 Pet $=$ Second Epistle of Peter \\
\hline Prov $=$ Book of Proverbs & Mt = Gospel according to & 1 Jn = First Epistle of John \\
\hline Eccl = Ecclesiastes & Matthew & $2 \mathrm{Jn}=$ Second Epistle of John \\
\hline Song $=$ Song of Songs & Mk = Gospel according to Mark & 3 Jn = Third Epistle of John \\
\hline $\mathrm{Job}=$ Book of Job & Lk $=$ Gospel according to Luke & Jud = Epistle of Jude \\
\hline Wis $=$ Wisdom of Solomon & Jn $=$ Gospel according to John & Rev $=$ Book of Revelation \\
\hline
\end{tabular}




\section{Introduction}

In this introductory chapter, first the Egyptian abbot Shenoute (floruit ca. 385-465), the main source for the textual corpus at the basis of this study, and his monastic federation will be introduced (1.1), then, the aim of this study will be clarified (1.2). Finally, the five research questions of this study will be presented (1.3).

\subsection{Shenoute: his life and times}

\subsubsection{Life and legacy}

Shenoute was described as "the Coptic author par excellence" by Anne Boud'hors and "the greatest of all writers in the Coptic language" by William H. Worrell. ${ }^{1}$ During his tenure as abbot of the

\footnotetext{
${ }^{1}$ Boud'hors 2017: 768 and Worrell 1945: 22 respectively. The floruit follows Behlmer 2019: 824. The
} male name "Shenoute," meaning "son of god" (originating from a compound of a)нpe "son" and Norte "god"), was common among Egyptians in Late Antiquity. Several ostraca from Western Thebes contain this name, referring to different persons; see Bacot 2009: 88, 103, 126, and 137. 
White Monastery Federation during the fourth to fifth centuries, ${ }^{2}$ his influence and political power grew. Stephen Emmel's reconstruction of Shenoute's literary legacy showed that he did not directly succeed his uncle, Pcol, the probable founder of the federation. Rather, Ebonh first succeeded Pcol as the abbot and archimandrite of the White Monastery Federation; he was then in turn succeeded by Shenoute. ${ }^{3}$

The term "White Monastery Federation" was coined by scholars ${ }^{4}$ to designate the three monasteries - two male and one female — that were under Shenoute's rule: the White Monastery, ${ }^{5}$ the Red Monastery, ${ }^{6}$ and the Nunnery (or Women's Monastery) in the temple of Atripe. ${ }^{7}$ The federation was located in the vicinity of modern-day Sohag, on the west bank of the Nile. On the opposite bank

${ }^{2}$ Cf. Emmel 2004b: 151-74 and Behlmer 2019, for an overview of Shenoute's career. For Shenoute's biography, see also Davidson 2018, Timbie 2015, and Krawiec 2013.

${ }^{3}$ See Canon 1, MONB.ZB, fragment 2v; Emmel 2004c: 9-10 and 569-70.

${ }^{4}$ The term "federation" was first used in Layton 2002, followed by, among others, Brooks Hedstrom et al. 2011: 333-64, and Brakke and Crislip 2015: 1ff.

${ }^{5}$ Arabic: ad-Dayr al-' Abyaḍ or Dayr al-'Anbā Šinūdah. For more information on the White Monastery, see Coquin et al. 1991a: 761-70. The monastery is located about 10km from modern Sohag, on the opposite bank from Akhmim, the city of Panopolis in Shenoute's time.

${ }^{6}$ Arabic: ad-Dayr al-'Aḥmar or Dayr al-' Anbā Bīšūy. See Coquin et al. 1991b: 736-40.

${ }^{7}$ See El-Sayed and El-Masry 2012; El-Sayed and Lakomy 2017; and Blanke 2019. 
stood Panopolis (modern-day Akhmim), one of the most prosperous Hellenistic cities in Upper Egypt during the late Roman and early Byzantine periods. ${ }^{8}$

It is a modern consensus that Shenoute himself did not live in his monasteries while he directed the federation but in a nearby cave in a cliff in the Nile Valley. ${ }^{9}$ From there, he sent written instructions to the monasteries, which he only visited to preach sermons at quarterly general assemblies. ${ }^{10}$ Many of these letters and sermons were compiled by Shenoute himself into Canons, Discourses, and other letters. This tripartite division of Shenoute's literary corpus was reflected in the Life of Shenoute (Vita Sinuthii) ${ }^{11}$

${ }^{8}$ See Egberts and van der Vliet (eds.) 2002 for more details on this city. The locations of Atripe and Panopolis in Egypt are shown on the map of López 2013: xii, and the locations of the three monasteries of Shenoute in and around Atripe are shown on the map of Brakke and Crislip 2015: xiv.

${ }^{9}$ See Bolman 2016: 31-32; López 2013: 1-2; and Schroeder 2013: 25.

${ }^{10}$ Leipoldt 1903: 132, n.4.

${ }^{11}$ This division is reflected in the Life of Shenoute; see Leipoldt and Crum 1906: 13, 1. 6-10. Emmel 2004c: 4, n. 3 explains, "Such a tripartite division of Shenoute's corpus is reflected in the Life of Shenoute 11 [...] Shenoute 'spoke a multitude of sermons (єзнгісіс) and holy discourses (入огос) full of commandment, and he set down canons (канюN) for the monks, and spicy letters (епістолн) fearful and comforting to the souls of the people.' For additional evidence that the Letters were regarded as a distinct component of Shenoute's corpus $[\ldots]$. 
Emmel summarized the discussion on the dates of Shenoute's birth and death. ${ }^{12}$ According to Emmel, Shenoute was probably not born until 361 or 362 at the latest $;{ }^{13}$ he is most commonly believed to have died in $465 .{ }^{14} \mathrm{He}$ was buried in a tomb in the White Monastery. ${ }^{15}$

To this day, the Coptic Orthodox Church of Alexandria reveres Shenoute as a saint. Important figures, monasteries, and groups related to Coptic Christianity were named after him, including figures such as Pope Shenouda III (1923-2012), places such as the Coptic Monastery of St. Shenoute near Rochester, New York, ${ }^{16}$ and organizations such as St. Shenouda the Archimandrite Coptic Society of Los Angeles. ${ }^{17}$ Moreover, according to Caroline T. Schroeder, the feast day of Shenoute is "one of the most popular Christian festivals in Egypt today."

${ }^{12}$ Emmel 2016: 937-44.

${ }^{13}$ According to Emmel 2004c: 11, Shenoute "was at least nine when he became a monk, which would mean that he was born not later than 361/362."

${ }^{14}$ Emmel 2016: 937.

${ }^{15}$ See Grossmann 2004 and Bolman et al. 2010.

${ }^{16}$ See the web article on St. Shenouda the Archimandrite Coptic Orthodox Monastery of Henrietta, New York by Gorman Jr. 2020.

${ }^{17}$ See the website of the St. Shenouda the Archimandrite Coptic Society at http://www.stshenouda.org (last accessed on March 9, 2021).

${ }^{18}$ Schroeder 2013: 163. 


\subsubsection{Canons and Discourses}

The Life of Shenoute ${ }^{19}$ is preserved in Sahidic Coptic, Bohairic Coptic, and several other languages and attributed to Shenoute's successor, Besa. However, it cannot be considered a historically accurate source.$^{20}$ Rather, Shenoute's own writings are considered the primary sources for a scientific reconstruction of his life. Moreover, they are crucial to the study of life at his monastic federation while he was the abbot.

This study focuses on Shenoute's Canon 6 and the works of his successor, Besa. According to Emmel's reconstruction, the 9 Canons (letters to monks and nuns about monastic discipline) and 8 Discourses (mostly homilies to general audience) are transmitted in codices, which are not preserved

\footnotetext{
${ }^{19}$ For the Bohairic version, see the work of Johannes Leipoldt with assistance from Walter E. Crum:
} Leipoldt and Crum 1906. In addition, there are Sahidic (fragmentary), Ge'ez, and Arabic versions of the Life of Shenoute. For a comprehensive study of these versions, see Lubomierski 2007a. Traditionally, the Life of Shenoute is considered to have been written by Besa (see Bell 1983: 3 and Cain 2016: 168). However, there has always been some doubt about its historical accuracy. In particular, Emmel 2004c: 7, fn. 7, stated, "In the chronological analysis that follows, I have tried to rely only on information from Shenoute's own writings and, in one instance, a work of his successor Besa. I exclude from consideration here the Life of Shenoute that is attributed to Besa.” Recently, the authorship of Besa has also been questioned by Lubomierski 2007a, 2007b, and 2008, whose results have been accepted, among others, by Brakke and Crislip 2015: 2 and Layton 2014: 28, who calls the author of the Life of Shenoute "pseudo-Besa."

${ }^{20}$ Lubomierski 2007a: 119. 
completely, but only in (groups of) pages or fragments. ${ }^{21}$ Canon 6 is attested by six codices: MONB.XF, MONB.XM, MONB.XV, MONB.YJ, MONB.YK, and MONB.XL. ${ }^{22}$ These modern sigla were established by the Corpus dei Manoscritti Copti Letterari (CMCL) ${ }^{23}$ For codices found at the White Monastery, where most of Shenoute's works were preserved, the siglum MONB (Monastero Bianco) is used, followed by two letters designating the individual codex.

The codices MONB.XF, MONB.XM, and MONB.XV only contain Canon 6, while MONB.YJ is questionably a codex representing Canon 6. The other two codices, namely MONB.XL (the so-called Florilegium Sinuthianum) and MONB.YK are Varia selected from Canons, Discourses, and others.

\subsubsection{The Coptic Bible at the time of Shenoute}

The most influential text in the White Monastery Federation and in Coptic monasticism in general was the Bible. Scripture was the source of almost all quotations and allusions in Shenoute's works. As David Brakke and Andrew Crislip observed,

\footnotetext{
${ }^{21}$ For basic information on the Canons and Discourses, see Emmel 2004c: 3-5. For detailed information
} of them and other works by Shenoute, see Emmel 2004c: 553-694. For a history of efforts to reconstruct the codices, see Emmel 2004c: 24-28.

\footnotetext{
${ }^{22}$ For codicological information about each codex, see Section 4.2.

${ }^{23}$ See Orlandi 1990, where he described the goal, process, and results of the CMCL project.
} 
[...] most of his works are saturated with biblical citations and allusions, and even Shenoute's own diction and vocabulary mimic that of the Coptic Bible so that it is difficult at times to differentiate between the voice of the Bible and that of Shenoute. These two elements - revelations from God and mastery of the Bible - fashioned Shenoute as a prophet, modelled on those of the Old Testament. ${ }^{24}$

Shenoute thus channeled the language of the Bible and thus incorporated the highest authority in Christianity into his monastic discourses, as if he had been a prophet from the Old Testament (OT). But which Bible did Shenoute use? Which books were officially part of the Bible in his lifetime, which books had been translated and were available in the White Monastery library, ${ }^{25}$ and was the text of the Bible similar to that preserved in later manuscripts from the same monastery?

Christianity was transmitted to Egypt in the middle of the first century and probably reached Alexandria first. ${ }^{26}$ However, the New Testament (NT) canon did not become stable or fixed until the fourth century. Marcion made one of the earliest attempts to establish an authoritative selection of texts in the so-called Marcion Bible of the second century. It consisted of the Gospel of Luke and the Pauline Epistles, but not the Letters to Timothy and Titus; it also included Marcion's own additions and

\footnotetext{
${ }^{24}$ Brakke and Crislip 2015: 4.

${ }^{25}$ For the overview of the White Monastery library, see Emmel and Römer 2008.

${ }^{26}$ Behlmer 2016: 145.
} 
modifications. ${ }^{27}$ After Marcion, several versions of the canons of the Bible appeared, such as the Canon Muratori. ${ }^{28}$

Decisive evidence for the canonization of the OT and NT canons was the Thirty-Ninth Festal Letter by Athanasius of Alexandria in $367 .{ }^{29}$ Shenoute's letters and sermons do not directly indicate whether he followed Athanasius' distinction between "canonical" and "to be read" biblical books, ${ }^{30}$ but he introduced the deuterocanonical books with the same formulae as the rest of Scripture. ${ }^{31}$ However, the Thirty-Ninth Festal Letter itself was well-known to Shenoute. According to Janet Timbie, he cited it in I Am Amazed, stating, "The great teacher of the faith, Apa Athanasius, said in his writings, "it is because of heresy that I wrote these things; but even more, (because of) the wretched Melitians, priding

${ }^{27}$ Schmid 1995: 59.

${ }^{28}$ Sundberg, Jr. 1973: 1 stated, “[t]he list of New Testament books [which] contains a collection of tracts and creeds that appeared between the second and fifth centuries and that seem to have been collected and transcribed in the eighth (or seventh) century."

${ }^{29}$ For the canonization of the Bible and the Thirty-Ninth Festal Letter, see Brakke 1994 and Pedersen 2009.

${ }^{30}$ Timbie 2007: 627. For an overview of Shenoute's quotations from the deuterocanonical books, see Feder 2020a: 225.

${ }^{31}$ For example, Crislip 2009: 259 shows a quotation from Sir 31:25 by Shenoute. 
themselves on that which is called apocrypha." ${ }^{32}$ Besides Athanasius, according to Timbie, the Festal Letter of 401 written by Theophilus of Alexandria was also inserted into I Am Amazed and was described as "writings of the blessed archbishop Apa Theophilus." Timbie stated that Shenoute's allegiance to Cyril of Alexandria is shown in Only I Tell Everyone Who Dwells in this Village; she concluded that "these references demonstrate Shenoute's knowledge of teaching in regard to scripture and his acceptance, in some manner, of episcopal guidance."33

Amongst the books of the Bible, Psalms was read aloud on many occasions and often learned by rote memorization in Christian monasteries in both the East and the West in Late Antiquity. This practice was observed in the White Monastery, ${ }^{34}$ as the Rules of Pachomius influenced members of the White Monastery Federation. ${ }^{35}$ Examples such as the Bohairic Life of Pachomius suggest that

${ }^{32}$ The translation comes from Timbie 2007: 626. The original Coptic text can be found in MONB.HB, p. 22. The source that Timbie translated was Lefort 1955a: 21.

${ }^{33}$ Timbie 2007: 626.

${ }^{34}$ Lundhaug 2010a: 146, also acknowledged the importance of Bible memorization in Shenoute's monastery, citing Layton 2007: 71: “[...] in Shenoute's White Monastery the practice of memorizing and internalizing Scripture was important enough to be included among the monastic rules."

${ }^{35}$ This is discussed in Section 4.1. 
Pachomian monks frequently chanted Psalms. ${ }^{36}$ Scholars such as Timbie argued that the White Monastery Foundation - the establishment of which was probably influenced by the monasteries of Pachomius — inherited comparable rules from the Pachomian monastic federation. ${ }^{37}$ She discussed this in her article on the function of the Song of Songs in the Pachomian and Shenoutean monastic traditions and Origen, comparing the Testament of Horsiesios, the Life of Pachomius, and Shenoute and Origen's works. ${ }^{38}$

The Life of Antony (Vita Antonii), which is attributed to and was likely written by Athanasius, features a scene in which Antony listens to the Gospel of Matthew as a young man (Mt 19:21). ${ }^{39}$ Peter

${ }^{36}$ According to Veilleux 1980: 40 and 50, Pachomian brothers read and sang around a dead brother and while preparing to bury a dead nun. Moreover, when Athanasius went to the south and visited Pachomius, Pachomius and his monks escorted him while chanting Psalms; see Veilleux 1980: 51.

${ }^{37}$ See Timbie 2013.

${ }^{38}$ In Timbie 2011: 510, she also makes an important statement on Shenoute's use of Scripture: "Shenoute seems to make less use of a 'mental dictionary'. In the Canons he confronts problems of discipline and argues with opponents in the White Monastery community by drawing on his deep familiarity with scripture. There is less use of key words to make connections and more use of themes or imagery from scripture."

${ }^{39}$ Mayer 1950: 20-21 translated the passage into English: "And it so happened that the Gospel was being read at that moment and he heard the passage in which the Lord says to the rich man: If thou wilt be perfect, go sell all that thou hast, and give it to the poor; and come, follow me and thou shalt have treasure in Heaven. As 
Nagel deduced that, since Antony could only understand Coptic, he must have listened to a Coptic translation of the biblical passage. ${ }^{40}$ Thus, Nagel concluded that a translation of the Gospel of Matthew must have existed around 270. Samuel Rubenson disagreed, however, and claimed that Antony had knowledge of Greek. ${ }^{41} \mathrm{He}$ argued that the sources that previously indicated that Antony could not read Greek were "not as unequivocal as earlier research implies." 42 The Historia Lausiaca is the only source to report that Antony did not know Greek and needed an interpreter for non-Coptic-speaking visitors. ${ }^{43}$

though God had put him in mind of the saints and as though the reading had been directed especially to him, Antony immediately left the church and gave to the townspeople the property he had from his forebears - three hundred arurae, very fertile and beautiful to see.” For the latest German translation by Peter Gemeinhardt, see Gemeinhardt 2018, and for a comprehensive study on Antony, see Gemeinhardt 2013.

${ }^{40}$ Nagel 1991: 1836 mentions that the Life of Antony by Athanasius is part of the evidence that a Coptic translation of the Bible - or, at least, of the Gospel of Matthew - existed around $270 \mathrm{CE}$ at the latest. Nagel deduced that the Gospel of Matthew that Antony heard must be a Coptic translation, since Life of Antony emphasizes that Antony knew only Coptic, not Greek. However, as Rubenson argued in Rubenson 1995, it is more likely that Antony could in fact read Greek, judging from his Letters. Rubenson 1995: 185, stated that “[...] contents of the letters indicate that Antony knew some Greek, a comparative analysis of all the versions preserved shows that the letters were composed in Coptic." For thoughts on Greek literacy among commoners in Egypt at the time, see Rubenson 1995: 109-11. For the letters of Antony, also see Garitte 1937.

\footnotetext{
${ }^{41}$ Rubenson 1995: 185.

${ }^{42}$ Rubenson 1995: 41.

${ }^{43}$ See Rubenson 1995: 41-42.
} 
In the Historica Lausiaca, the interpreter is named as Kronios. However, according to Rubenson, there are scenes in the same source in which Antony communicates with leading theologians and secular authorities and engages in discussion with philosophers. Therefore, Rubenson argued that "it seems unlikely that he had no background in Greek, even if he is likely to have preferred to speak in his own mother tongue, and that of his disciples. ${ }^{, 44}$ Rubenson added that, among Coptic speakers of Antony's time, partial knowledge of Greek was probably more common than previously assumed. Therefore, he believed that it was highly plausible that Antony listened to the Gospel of Matthew in the original Greek. Consequently, it is highly questionable whether the Gospel of Matthew had already been translated by the time of the episode in the Life of Antony. By the time Shenoute assumed office around 385, however, all books in the Athanasian canon of the Bible appear to have been translated into Coptic. Shenoute quoted nearly all the biblical books in his works, and most of the verbatim quotations are close to the existing Sahidic translations. In addition to mentioning the Thirty-Ninth Festal Letter by Athanasius, ${ }^{45}$ Shenoute quoted the festal letter of 410 by Theophilus of Alexandria. According to Emmel, he only slightly reworded the original text. ${ }^{46}$ Therefore, according to Alberto Camplani, ${ }^{47}$

\footnotetext{
${ }^{44}$ Rubenson 1995: 41-42.

${ }^{45}$ Pedersen 2009: 168. In addition, see Feder 2016: 331.

${ }^{46}$ Timbie 2007: 627.

${ }^{47}$ Camplani 2003: 49.
} 
Shenoute could in fact read Greek and probably translated the original text of Theophilus's festal letter from Greek to Coptic himself. ${ }^{48}$

Although it is likely that Shenoute was able to read Greek, he quoted verbatim or near verbatim from Coptic translation(s) of the Bible. ${ }^{49}$ The White Monastery was one of the most important centers of Bible production in Late Antique Egypt. The biblical manuscripts produced there form one of the two most significant groups of sources for the reconstruction of the Sahidic Bible ${ }^{50}$ the other being from the

${ }^{48}$ For more on Shenoute's Greek ability, see Emmel 1995: 93-99, 2007: 90-91, 2008: 41. In addition, Bagnall 2008: 29 stated, "[...] that Shenoute had an excellent education, particularly in rhetoric, is by now widely accepted, and he, like other writers, must be taken as part of a much larger phenomenon of Mediterranean antiquity with heirs in much later periods as well. I do not, in saying this, mean to suggest the existence of uniformity in Christianity across time any more than in antiquity; far from it. But some types of argument seem deeply embedded in Christianity and to survive differences in time, place, and doctrines. One of them is precisely the presumption that in fact Christianity is essentially characterized by doctrinal uniformity and that maintaining such uniformity is of vital importance. Deviations are then treated as aberrant. Far from being merely an 'ideal in Coptic sermons', as Frankfurter dismissively put it, the drive for unity and uniformity is a central ideological tenet and motive force in the history of Christianity. The fact that in reality Christianity as a movement has, from its earliest days, been characterized by diversity of doctrine in no way negates the centrality of debate that takes for granted that there is only one true set of doctrines." In addition, see Nasim 1991: 931, who considers the Catechetical School of Alexandria the earliest form of Coptic education.

${ }^{49}$ For the state of research on the Coptic translation of the Bible, see Feder 2020a.

${ }^{50}$ Feder 2016: 335 estimates that the White Monastery alone possessed about 100 biblical codices. 
Monastery of the Archangel Michael at Phantoou (al-Hamuli) in the Fayyum. ${ }^{51}$ However, as with the manuscripts of Shenoute's works, the biblical codices from the White Monastery were dispersed from the 18th century onwards. They were acquired as single leaves, blocks of leaves, or mere fragments by European dealers or missionaries and were eventually scattered across several museums and libraries, mainly in Europe and North America. ${ }^{52}$ The study of the Coptic OT has been recently advanced by various scholars, such as Karlheinz Schüssler, ${ }^{53}$ Peter Nagel, ${ }^{54}$ Hany Takla, ${ }^{55}$ and Frank Feder ${ }^{56}$ A digital edition of the Sahidic Coptic OT is currently being prepared by the Göttingen Academy of Sciences and Humanities under the leadership of Heike Behlmer and Feder, ${ }^{57}$ while the Coptic NT is being studied at the Institut für Neutestamentliche Textforschung in Münster as part of the Editio Critica

${ }^{51}$ Feder 2016: 335.

${ }^{52}$ Feder 2016: 335

${ }^{53}$ Schüssler 1995, 1996, 1998, 2000, 2001, 2003, 2004, 2006, 2007, 2009, 2010, 2011, 2012, and 2015.

${ }^{54}$ Nagel 1960, 1974, 1983, 1984a, 1984b, 1987, 1988, 1989, 1991, 1994, 1999, 2000, 2002, and 2016.

${ }^{55}$ Takla 1996, 2005, 2007, 2008, and 2010.

${ }^{56}$ Feder 1998, 2001, 2002, 2007, 2016, 2017, 2020a, and 2020b.

${ }^{57}$ See Behlmer and Feder 2017. The URL of the project is http://coptot.manuscriptroom.com, last accessed on November 22, 2021. 
Maior of the Greek NT. ${ }^{58}$ This will enable, e.g., text reuse studies like the present research to be carried out on an improved data set and be a solid basis for future studies on all aspects of the Coptic Bible.

\subsubsection{Hellenistic influence on Shenoute}

Tito Orlandi, speaking about Shenoute's monastery, states that under his leadership, "the monastery became, inter alia, the center of the Coptic literary culture, as Shenoute himself became by far the greatest Coptic writer, and also promoted a vast work of translation of Greek patristical texts." Greek was used as a literary tool by the Egyptian elites from the conquest of Egypt by Alexander the Great in $332 \mathrm{BCE}$ until the Arab Conquest of Egypt in the seventh century. ${ }^{60}$ Upper-class citizens in Egyptian urban areas, including Panopolis, the closest city to Shenoute's monasteries, received a complete Hellenistic education. ${ }^{61}$ Nevertheless, reading Coptic was taught in the bilingual Greek-

${ }^{58}$ See the Institut für Neutestamentliche Textforschung's website: https://ntvmr.uni-muenster.de, last accessed on November 4, 2021.

${ }^{59}$ Orlandi 2002: 211.

${ }^{60}$ The enormous influence of Greek dates back to the Saite period, according to Bagnall et al. 2004: 12.

${ }^{61}$ In addition to the Hellenistic influence, Aufrère 2006 discusses the possible influence of the Demotic tradition on Shenoute. Becker 2008: 46-49 argues the Hellenistic and Ancient Egyptian influences on Shenoute, who was very well educated in Christian literature as well. 
Egyptian milieu of Pachomian and later monasticism, ${ }^{62}$ and Coptic was the language of translation for culturally significant texts written in Greek and, occasionally, Syriac. ${ }^{63}$

Although Shenoute most likely did not use Greek as his everyday language, the scholarly consensus assumes that he was able to understand key Christian texts originally written in Greek as well as Greek rhetorical techniques. ${ }^{64}$ The writings and theology of Alexandrian patriarchs, such as Athanasius, Cyril, ${ }^{65}$ Dioscorus, ${ }^{66}$ and (Pseudo-)Clement had an enormous influence on Shenoute's monastery federation. Shenoute quoted the letters of Antony, whom he considered the great forerunner

${ }^{62}$ For relics of Coptic writing education in Upper Egypt, such as ostraca of Coptic writing exercises, see Cromwell 2013 and 2015. For more on the use of Coptic as a communication vehicle in early monasticism in Egypt, see Choat 2013, Choat and Giorda 2017, and Bagnall and Cribiore 2006.

${ }^{63}$ For example, some Manichaean literary texts from Kellis are considered to have been translated from Syriac into Coptic. Examples can be found in Gardner (ed.) 2007 and 2008.

${ }^{64}$ Emmel 2007: 91.

${ }^{65}$ See Dilley 2017: 78: “This is particularly significant for the study of writing practices in the White Monastery Federation, as Cyril was Shenoute's epistolary correspondent, and he included the monk in his entourage to the Council of Ephesus in 431.” The relationship between Shenoute and Cyril was also mentioned by Griggs 1990: 230.

${ }^{66}$ As for the correspondence between Shenoute and Alexandrian patriarchs such as Dioscorus, see Moawad 2008: 107-19, Lundhaug 2013: 249-52, Davis 2008: 62-64, Brakke and Crislip 2015: 8-9, and Feder 2020a: 214. 
of monastic life ${ }^{67}$ and works by other authoritative Christian writers, such as Athanasius. Shenoute also quoted works, the authorship of which is doubted in modern times, such as Pseudo-Clement.

A comparison of Shenoute's writing style and that of other Late Antique Christian authors reveals both similarities and differences. For example, whereas Clement of Alexandria often quoted the Gospel of John, Greek philosophers, and writers from the classical period while mentioning the names of quoted authors, ${ }^{68}$ Shenoute rarely named the sources or authors of the texts that he quoted. This is not surprising insofar as his audience — monks and nuns — were expected to be familiar with only his main source text, the Bible.

The polemics against heresies, which are found in works by the Alexandrian fathers, are reflected in the writings of Shenoute. For example, he referred to Athanasius's Thirty-Ninth Festal Letter from 367 in Who Speaks Through Prophets and claimed that he learned how to distinguish heresies

${ }^{67}$ See Garitte 1937: 20-22; Rubenson 1995: 16, 36, 99, and 125.

${ }^{68}$ For example, Clement of Alexandria, The Stromata, or Miscellanies, Book V, Chapter XII, Roberts and Donaldson 1885: 463: “Accordingly Solon has written most wisely respecting God thus:- 'It is most difficult to apprehend the mind's invisible measure. Which alone holds the boundaries of all things;' for 'the divine,' says the poet of Agrigentum,--'Is not capable of being approached with our eyes, or grasped with our hands; but the highway, of persuasion, highest of all, leads to men's minds."” 
such as Manichaeans from it. ${ }^{69}$ Although Origenism was officially considered to be a heresy only in 553

CE, Shenoute followed several Egyptian Christian leaders in their condemnation of Origen and his followers, such as in I Am Amazed (also known as Contra Origenistas). ${ }^{70}$ The same holds true for Shenoute's polemic against Manichaeans. ${ }^{71}$

Thus, we can assume that Shenoute knew most of the anti-heretical writings of contemporary Greek fathers. ${ }^{72}$ In his lifetime, the monastery was a center for the translation of Greek texts into Coptic. It is probable that Shenoute had already made or rather commissioned Coptic translations of these writings.

${ }^{69}$ Who Speaks Through the Prophet, MONB.ZM p. 44, the Bibliothèque Nationale de France (Paris), $131^{4}$ f. 158, according to Emmel 2004c: 682 . Using the same work, Shenoute's stance against Origen was clearly highlighted by Lundhaug 2017: 218-20. In addition, according to Lundhaug 2017: 218 and Timbie 2007: 62728, Shenoute quoted Epiphanius and thus read his writings.

${ }^{70}$ See Cristea 2011, which is a complete re-edition of this work. Another well-known title, Contra Origenistas, was given by Orlandi 1985, which is an incomplete edition of I Am Amazed. However, according to Moussa 1998/1999: 20, the title Contra Origenistas was not attested anywhere. Thus, the title is misleading. Lundhaug 2012b clarified that Shenoute indiscriminately used terms of condemnation for his opponents. For more on this topic and Shenoute's opposition to Origenists, see Lundhaug 2013: 224-28. In addition, for more on Shenoute's attitude towards apocryphal books, see Lundhaug 2012b: 261.

${ }^{71}$ Shenoute also showed indiscriminate condemnation to Manichaeans; see Richter 2008: 127

${ }^{72}$ More detailed proposals were made by Hugo Lundhaug; see Lundhaug 2012a. 


\subsubsection{Appropriation of biblical figures for authority}

Several scholars, including Emmel, ${ }^{73}$ Schroeder, ${ }^{74}$ Krawiec, ${ }^{75}$ López, ${ }^{76}$ and Brakke, ${ }^{77}$ have highlighted Shenoute's self-identification as an OT prophet or the Apostle Paul, as mentioned briefly already. In Canon 6, he often called himself a sinner rather than a prophet or an apostle. The act of

${ }^{73}$ Emmel 2004c: 8 .

${ }^{74}$ In Canon 1, according to Schroeder 2013: 38, Shenoute acted as a prophet "in the role of a new Jeremiah.” In addition, Schroeder 2013: 40-41 highlighted various other scenes in which Shenoute acts as a prophet and "invokes the language of the biblical prophets." Schroeder stated that, as both an ascetic and a prophet, Shenoute possessed greater perceived authority than anyone else in his monastic federation (Schroeder 2013: 49).

${ }^{75}$ Krawiec noted that Shenoute developed "self-presentation as a prophet" (Krawiec 2002: 54) and explored in detail the prophetic role that he played (Krawiec 2002: 55-66). She concluded her argument on Shenoute's discourse of monastic power by stating that "Shenoute based his claims on a variety of arguments, all of which were designed to convince his followers that he was like an Old Testament prophet: inspired and guided by God, totally obedient, accepting of suffering, humble and yet authoritative in his leadership" (Krawiec 2002: 71).

${ }^{76}$ López 2013: 2-3 also stressed that Shenoute was “at once Desert Father and biblical prophet” and that he had a "prophetic self-understanding" and used "prophetic language." He even mentioned "Shenoute's 'prophetic' life."

${ }^{77}$ Brakke 2009a: 97-124. 
calling oneself a sinner echoes the prophets' lamentation of their own sins in Penitential Psalms. ${ }^{78}$ That the later monastic tradition considered Shenoute a "prophetic father" can be seen in the Life of Shenoute by Pseudo-Besa ${ }^{79}$ and On Christian Behaviour by Pseudo-Shenoute. The latter, which was written on a manuscript found in the Monastery of the Archangel Michael at Phantoou (al-Hamuli) in the Fayyum, ${ }^{80}$ called him "our holy father, the prophet, Apa Shenoute":

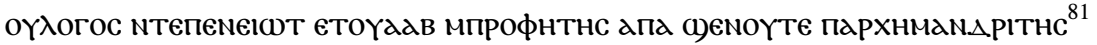

${ }^{78}$ Ps 6, 31, 37, 50, 101, 129, and 142 (LXX).

${ }^{79}$ See Section 1.1.1.

${ }^{80}$ This codex is now preserved at the Pierpont Morgan Library, New York as M604. There are two editions of this work: (1) Kuhn 1960a (English translation: Kuhn 1960b) and (2) Kosack 2013.

${ }^{81}$ From Kuhn 1960a: 2. In this dissertation, the spacing style of Coptic text follows Layton 2011: 25-26, who recommended the use of spaces between prosodically bound unit called "bound groups." Layton categorized Coptic morphemes into initial, non-terminal, medial, terminal, and unbound. The morphs except the last consist of a bound group. This grouping is based on the position of the morph and the prosody, such as stress, phonological boundness, and grammatical dependence (e.g., the possible insertion of discourse enclitic particles such as rap, ¿є. oYN). Haspelmath 2014 calls this bound group the "stress group." When the source editions cited in this dissertation used other spacing styles for Coptic, such as Till 1942 (one of the most common styles), I converted them to Laytonian spacing, which is required for the use of Coptic SCRIPTORIUM tools. For Coptic SCRIPTORIUM's tools, see Subsections 3.1.4 and 3.2.1.3. Punctuation, diacritical signs, and paratextual 
A sermon of our holy father the prophet, Apa Shenoute, the archimandrite ${ }^{82}$

It is worth discussing in greater detail this identification of the later tradition and of Shenoute himself. Shenoute's sermons and letters, the only witnesses we have of his interactions during his lifetime, often displayed the language and prophetic style of the OT. In López' study of the political and social role of Shenoute among the rural poor in Upper Egypt, he suggested that Shenoute used the sexual language of the OT to rebuke Panopolis: its sins were presented in the gendered metaphors of female fornication, ${ }^{83}$ of which the male OT prophets accused the female-identified cities of Jerusalem and Babylon - and which Shenoute ${ }^{84}$ applied to the city across the Nile. For example, López noted that Shenoute used the word anomia in the OT sense:

Anomia is a central concept in the language of the Old Testament prophets and the Psalms, where it refers to sinfulness, idolatry, immorality, etc. As Shenoute uses it, it seems to have both this Old Testament meaning and a contemporary, more concrete one: behavior that violates Roman Christian laws. ${ }^{85}$

Moreover, López simultaneously described Shenoute as a Desert Father —one of the early Christian hermits that usually solitarily dwelled in the desert practicing asceticism-and a biblical

ornaments are not shown in this study unless they are significant to an argument. Throughout this study, punctuation, diacritical marks, and paratextual ornaments are not shown unless they are significant.

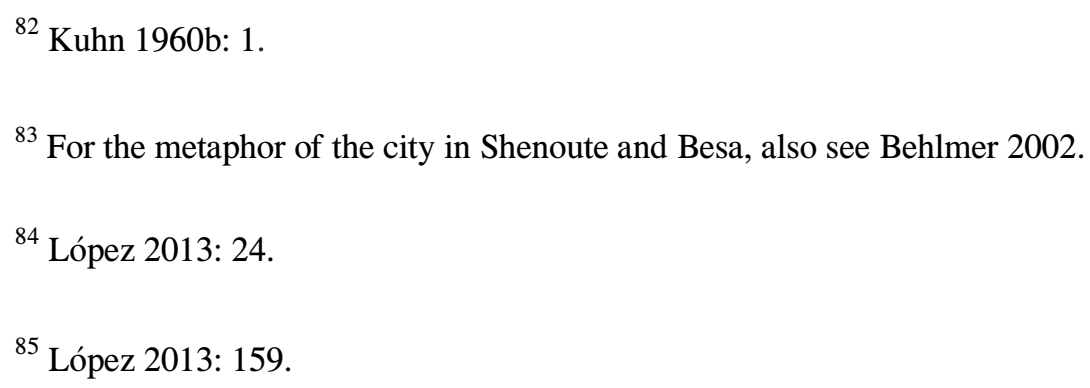


prophet, to whom the desert is a refuge from a sinful world and "a platform from which the powers of the world could be challenged and confronted with irrefutable evidence of their injustice." ${ }^{96}$ Likewise, Schroeder observed that

his every move, be it rhetorical through his exegesis of Jeremiah, or physical through his semianchoritic withdrawal to the desert outside the monastery, puts Shenoute in a position of greater perceived authority as both an ascetic and a prophet in the biblical mold. ${ }^{87}$

A question that warrants further discussion is how Shenoute's self-identification as a prophet can be linked to the rhetorical violence and descriptions of actual physical violence found in his works. ${ }^{88}$ This link can be made in relation to different aspects of his time as abbot. One of the most effective strategies that Shenoute used to govern a large number of monks and nuns was to display the authority conferred on him by God by harnessing the authoritative language of the Bible and assuming the authority of certain figures named in Scripture.

For example, Shenoute appeared as the prophet who, from his cave, chastised the sins of Panopolis and his monastic community. He distanced himself from these two societies, which were

\footnotetext{
${ }^{86}$ López 2013: 2.

${ }^{87}$ Schroeder 2013: 49.

${ }^{88}$ Bell 1983: 9 stated, "He was a self-confident autocrat and a dictator, and a man who had no hesitation
} in inflicting grievous bodily harm on those who transgressed his commands." Griggs 1990: 230 described Shenoute as "an autocratic and violent leader." For a more in-depth discussion of Shenoute and violence, see Hahn 2004: 223-69. 
worldly to his eyes, and reprimanded them. Moreover, López embedded Shenoute's prophetic rhetoric into a wider macro-social perspective on Late Antique Egypt:

Shenoute's "prophetic" life did not take place in a social vacuum, but against the background of major social and cultural transformations in Late Antique Egypt. These transformations need to be spelled out clearly if we are to understand the significance of Shenoute's actions and what made them possible in the first place. ${ }^{89}$

Shenoute's vehemence and violent rebukes have been interpreted as oppression of his monks and nuns. ${ }^{90}$ Krawiec highlighted that Shenoute's self-understanding as head of the monastery was shaped by his two self-presentations: a prophet who related wisdom received from God and a suffering servant. ${ }^{91}$ She stated that Shenoute's self-identification as a prophet in his monastic leadership role was typical in Late Antique Egypt — both anchoritic and cenobitic — and that monastic leaders at the time would have been required to develop characteristics such as Shenoute's to lead monks and nuns to salvation. ${ }^{92}$

${ }^{89}$ López 2013: 3. This political view of Shenoute as an advocate for the poor was first taken by Leipoldt 1903: 161 in his pioneering monograph on the abbot.

${ }^{90}$ Christian Casey compared this with the anti-intellectualism seen in the United States during the presidency of Donald Trump. See Casey 2016.

${ }^{91}$ Krawiec 2002: 51.

${ }^{92}$ Krawiec 2002: 52. 
Shenoute's appropriation of the language of OT prophets, the Psalmist, and Paul makes him a composite prophetic figure who harshly rebuked humankind and lamented the state of the community in which he lived. Notably, the prophetic figure was not limited to the OT prophets but also the poet of the Psalms. Several NT figures played a prophetic role, such as Jesus, Stephen, and Paul.

Jesus himself is depicted as the Son of God and the Messiah in the Gospel of Matthew, not a prophet. In Mt 24:1-2, he foretold the destruction of the Temple of Jerusalem just as prophets foretell future events told by God. The figure of a prophet in the Hebrew Bible was transmitted from the OT to the NT and, ultimately, to early Egyptian monasticism.

Shenoute himself, however, told monks and nuns (e.g., in Canon 6) that he was neither an apostle nor a prophet, but a sinner. ${ }^{93}$ This assertion did not contradict his self-image as an apostolic prophet because being a sinner is a general prerequisite for Christians and a literary topos used by even the most exalted figures in Christendom. The theme of sin is omnipresent among the prophetic figures, particularly the poet of the Psalms, whom Shenoute - like other biblical figures - revered as a saint. In

${ }^{93}$ For examples in Canon 6, євод хеамгоүрєчрмове ("because I am a sinner"; Then Am I Not Obliged,

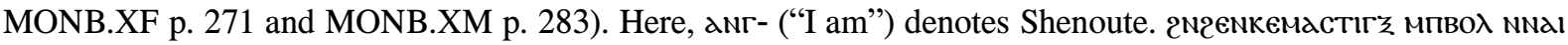
мтакпацлєүє мпарєчрповє мгнтоҮ (“in addition to those sufferings you have already punished me, a sinner?"; Then Am I Not Obliged, MONB.XF, p. 265 and MONB.XM, p. 278), and мн оүпрофнтнс пє н оүапостодос пє

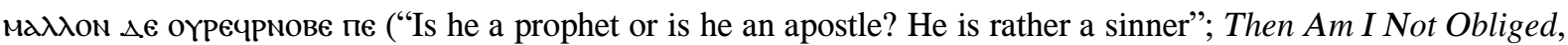
MONB.XF p. 333). Here, $\pi є$ ("he is") probably denotes Shenoute. Thus, Shenoute calls himself as a sinner from time to time. 
the following passage, Shenoute quoted from Psalms with the quotation signal mec)ak pळ nтапєтоүaגB $\chi$ ooc $\chi \in$ ("perhaps it itself is what the Saint said"):

\section{Shenoute's Canon 6, Remember O Brethren, MONB.XV pp. 73-74}

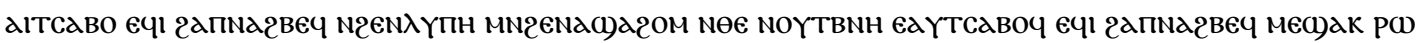

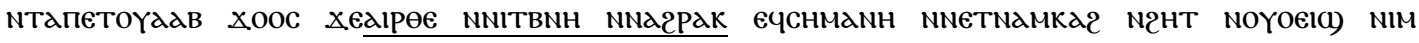

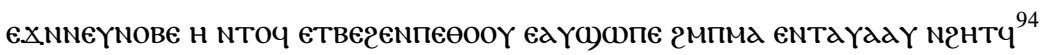

I learned to bear the yoke of sorrows and groans, like a beast which has been taught to endure the yoke; perhaps even when the saint said, 'I was like those beasts in your presence!' did he mean those who are afflicted by their sins at all times, or rather evil things that have occurred where they have been done $?^{95}$

${ }^{94}$ MONB.XV, pp. 73-74. As noted in fn. 20, all the punctuations and diacritical marks are omitted unless necessary. They will be shown in the digital diplomatic edition of Shenoute's Canon 6 manuscripts, which Julien Delhez and the present author are working on under the supervision of Heike Behlmer at Subproject B05 ("Biblical Interpretation and Educational Traditions in the Coptic-speaking Egyptian Christianity of Late Antiquity: Shenoute, Canon 6") in Sonderforschungsbereich (SFB) 1136 ("Education and Religion in Cultures of the Mediterranean and Its Environment from Ancient to Medieval Times and to the Classical Islam”). For detailed information about SFB 1136 and Subproject B05, see Section 3.1.1.

${ }^{95}$ Amélineau 1914: 321, fn. 3 indicates that this is a quotation from "Psalm., LXIII, 23." However, the chapter number must be a typo of LXXIII. 


\section{Source: Ps $72: 22$}

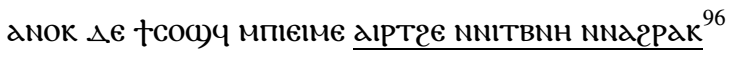

As for me, on the other hand, I was despised and ignorant. I was like those beasts in your presence.

As noted by Krawiec, Shenoute often played the role of the "suffering servant" in Canon 6 rather than the bolder prophetic figure of Canon $1 .{ }^{97}$ Since OT prophets such as Jeremiah, Isaiah, Hosea, and Elijah were also depicted as suffering servants, these two characteristics are not necessarily mutually exclusive. Krawiec quoted Shenoute as saying, "How have the prophets and the apostles been servants to the Lord but that they chose to suffer with others and that they died for the name of the Lord?"98 This was Shenoute's main point repeated numerous times throughout his letter, Abraham, Our Father from Canon 3, on a crisis in which a monk refused a promotion. ${ }^{99}$

${ }^{96}$ From the "base text", of the Sahidic OT provided by the Digital Edition and Translation of the Coptic-Sahidic Old Testament project at the Göttingen Academy of Sciences and Humanities; http://coptot.manuscriptroom.com, last accessed on November 22, 2021. For more on this base text, see Subsections 3.1.1 and 3.2.1.2

${ }^{97}$ Krawiec 2002: 66.

98 Amélineau 1907: 30, translated by Kraweic 2002: 211.

${ }^{99}$ This passage is quoted from Krawiec 2002: 211. At the end of the passage, Krawiec references Amélineau 1907: 30-32, enclosing the name of the source in parentheses. I modified her parenthetical references into footnote references. 
The images that Shenoute appropriated thus merged into that of a figure who suffered from the disobedience of his audience, conceptualized as fornication. He cared for the world but suffered from its refusal to listen to him despite his divine authorization to speak; therefore, to obey him was to obey God. According to Shenoute, to observe discipline, repent when reproached, and obey his instruction, which was a mandate from God, was to follow God himself. To return to the central theme of this study, quotations from the Bible were carefully selected to support Shenoute's composite role. He lamented and reproached the monastic community to elicit its repentance; at the same time, he chastised himself and implored God to help him in his agony. Reproaches from the prophets, Psalms, Proverbs, Ecclesiastes, the Letters of Paul, and the sayings of Jesus were selected to reprimand the monastic community (in Coptic: тсүмагогн). Here, the monastic community is substituted for the original addressees of the biblical reproaches. As will be seen in more detail, Shenoute often slightly changed the original text of the Bible to fulfil this purpose; for example, references to the people of Israel (masculine in Coptic) became references to the community (тсүмагогн; feminine in Coptic). ${ }^{100}$

\subsection{Aim of study}

The main aim of this study is to examine in how far digital text reuse technology can contribute to clarifying biblical quotations and allusions in Canon 6. By skillfully using quotations from and allusions to the Bible, he played the role of a Mosaic figure who variously presented himself as (1) the

100 Schroeder 2013: 28. 
righteous sufferer, (2) an OT prophet, and (3) the apostle Paul. The key to a study of quotations in Shenoute is how he used these biblical phrases to remind monks and nuns of his biblical role and divinely mandated authority. Hence, it would be valuable to identify all the quotations and allusions that have not been discovered in previous studies of Shenoute's Canon 6. In this work, Shenoute highlighted his role as a righteous man who suffered from his own sins and those of his monastic community. This is comparable with Canon 1, in which Shenoute often used a prophetic style of discourse, as indicated by Schroeder.

In her monograph on Shenoute's monastic discipline, Schroeder raised several important questions on quotations from and allusions to the Bible in Canon $1 .{ }^{101}$ The latter consists of letters mainly composed in what Schroeder called "a prophetic style." She continued, "The letters are so steeped in scriptural quotes or a scriptural writing style that the reader is faced with the question of how to relate these biblical passages to Shenoute's particular context." ${ }^{, 102}$ Any interpretation of Shenoute's writings requires an interpretation of the abundance of quotations and allusions that he used. For example, Schroeder quoted the following passage from Canon 1:

But know this: A voice came three times around our congregation saying, 'The destroyer came among you; the destroyer ruled over a portion of you, and he took it prisoner to a distant land; the destroyer overturned the enclosing wall of your congregation, and he destroyed the choice bunches of fruit of the grapevine, and he stripped its twigs; he crushed the fig trees; he destroyed the pomegranate trees

${ }^{101}$ Schroeder 2013.

${ }^{102}$ Schroeder 2013: 26. 
and the apple trees and the olive trees; he gathered or he collected their fruit; he caused them to fall down to the earth; he chopped down the choicest of the tall trees in your midst (cf. Joel 1:7, 12); he destroyed the lambs of the fold; he destroyed the mature rams. For apart from the fact that among us a remainder exists from the Lord, we would become like Sodom and those of Gomorrah' (Is 1:9). ${ }^{103}$

Schroeder raised several questions about the quotations from and allusions to the Bible in this passage: ${ }^{104}$

1. "Are the passages metaphors for the situation in the monastery?"

2. "Do references to biblical events and characters provide examples of the kinds of activities that are actually going on in the community?"

3. "Or are they unspecified admonitions to pursue virtue and avoid vice?"

4. "For example, how does one interpret the reference to Sodom and Gomorrah in the passage quoted above?"

a. "As a reference to sins of sexual indiscretion or inhospitality that have occurred in the community?"

b. "As an example of the destruction facing the monastery?"

${ }^{103}$ For Codex MONB.XC of Shenoute, Canon 1, see Leipoldt 1908: 195-96 and the translation by Schroeder 2007: 25. Cf. Emmel 2004b: 165-66.

${ }^{104}$ Schroeder 2013: 27. 
c. "As a generalized warning of the potential of God's retribution against sinners?"

d. "Or as all of these options?"

According to Schroeder, Shenoute took the role of the "literary and anthropological model of the biblical "peripheral prophet." 105 This "peripheral prophet" has many facets. First, he stands outside the "primary religious and political authority system" and warns the community from "a marginal, but not wholly outside, position." Second, he mediates between the community and God "by claiming to receive direct revelations from God." Third, he takes "the role of a Mosaic figure who reveals and interprets God's law for his community." Fourth, he calls “on the community's leadership to enact reforms, especially concerning their adherence to God's law." Finally, he experiences "opposition, persecution, and/or isolation from the community's centers of religious and political power." To have authority over monks and nuns, Shenoute had to act as this "Mosaic figure," drawing on various biblical exempla in the process.

Schroeder's questions about Canon 1 can also be asked about Canon 6. However, according to her, Shenoute wrote Canon 6 in a less prophetic style than Canon 1. He wrote the letters in Canon 6 as a sinful and suffering righteous rather than a self-declared prophet. In fact, he quoted sentences from Psalms or Isaiah in Canon 6, which underscored his status as a sinner as well as a persecuted and righteous man. In his canons and discourses, Shenoute also frequently quoted Paul's letters (and Deuteropauline letters) from the NT, frequently using language such as "as the Apostle said." However,

${ }^{105}$ In this paragraph, all the quotations are from Schroeder 2013: 27. 
in Then Am I Not Obliged from Canon 6, his self-identification as Paul was foregrounded far less than his identity as a suffering righteous. In fact, he wrote,

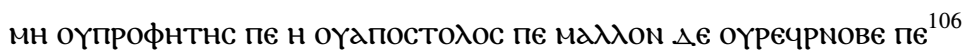

"Is he a prophet or is he an apostle? He is rather a sinner."

In this passage, Shenoute refers to пєто)дхє ммме ("the one who speaks with you"; the monastic community $=$ тсүмагогн), namely himself. Moreover, he wrote the following in the same work:

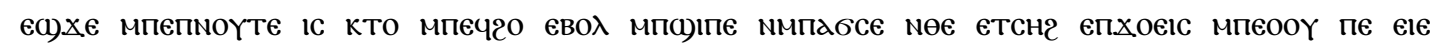

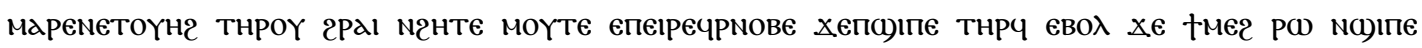

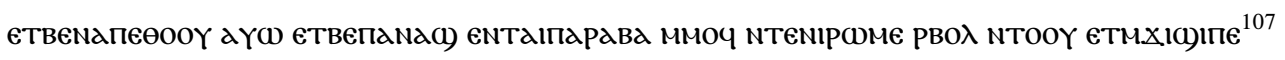

"If the God, Jesus, did not turn his face from the shame of spittle, as it is written, 'even if he is the Lord of glory, then let all who dwell in you call this sinner: All shame, for I am as ashamed because of my sins and my oath that I have transgressed, and that these men escape shame."

In the two passages above from Then Am I Not Obliged in Canon 6, Shenoute confesses his sins and shame. However, he also issued many cautions to the monastic community, or specific recipients of his letters, such as Tapolle and other women at the end of Then Am I Not Obliged. In this sense, he

\footnotetext{
${ }^{106}$ MONB.XM p. 333, col. 2, 1. 25-30.

${ }^{107}$ Then Am I Not Obliged, MONB.XF pp. 272-73. This sentence has a parallel in MONB.XM pp.
} 284-85. 
was a person who admonished the monastic community but, at the same time, was ashamed of his sins.

The image Shenoute presents in Canon 6 is closest to the "suffering servant of God" expressed in many of the Psalms. In the latter, the poet confesses his sins while accusing others of being responsible for injustice in the world and imploring God to protect him. This is also particularly characteristic of the fourth work in Canon 6, Then Am I Not Obliged. In He Who Sits Upon His Throne and Is It Not Written, the word "sinner" (речрмове) often refers to an evildoer in the monastic community or the world. In Then Am I Not Obliged, it mainly refers to Shenoute himself, who is probably playing the role of the suffering righteous one.

\subsection{Research questions}

The central goal of this study is to elucidate how Shenoute reused biblical language in his writings. To this end, several research questions were formulated: ${ }^{108}$

- Research Question 1: Do the textual findings indicate quotations from memory rather than from books or excerpts?

- Research Question 2: How accurate is the quotation? How can discrepancies be explained?

- $\quad$ Research Question 3: What contextual signals were employed to mark quotations?

${ }^{108}$ These research questions were also asked in the Subproject B05 proposal for SFB1136. For detailed information on SFB1136 and Subproject B05, see Section 3.1.1. 
- Research Question 4: Is there a connection between the introduction of a biblical argument and the faithfulness of a quotation? In other words, is an adoption marked as a quotation more literal than an unmarked adoption?

- $\quad$ Research Question 5: What are the opportunities and limitations of digital tools?

Shenoute's biblical quotations and allusions potentially provide a valuable case study of how leading monks used the authority of the Bible in their educational discourse in Coptic-speaking Christianity in Late Antique Egypt. Until recently, such research was hampered by the dispersal and fragmentation of Shenoute's literary production. It has now been greatly facilitated by Emmel's codicological reconstruction of the manuscript tradition. ${ }^{109}$

Even in Late Antiquity, Shenoute was not well-known outside the Coptic-speaking Egyptian Christian world. Shenoute himself indicated that he had attended the First Council of Ephesus. ${ }^{110}$ In the Bohairic Life of Shenoute, he accompanies Archbishop Cyril to the council. It is elaborately narrated that he punched Nestorius in the chest and was thus instrumental in the council's condemnation of the latter as a heretic. ${ }^{111}$ The Acts of the Council of Ephesus, however, does not mention anything about Shenoute's presence. ${ }^{112}$ In addition, Shenoute was not mentioned in the Historia Lausiaca by Palladius, the Historia Monachorum in Aegypto, or other contemporary Greek or Latin sources.

\footnotetext{
${ }^{109}$ Emmel 2004c.

${ }^{110}$ In his work I Have Been Reading the Holy Gospels, cf. Moussa 2010: 117.

${ }^{111}$ See Bell 1983.

112 See Price and Graumann 2020. There is also a Coptic version of The Acts; see Kraatz 1904.
} 
Due to the lack of non-Coptic sources and the fragmentation of Coptic sources, Shenoute was long underrepresented in Western scholarship. Before Emmel's reconstruction of his works, studies of Shenoute's letters and sermons were rare and more difficult to conduct. With very few exceptions, such as Leipoldt's study, ${ }^{113}$ this was also true of studies on monastic education in Shenoute's federation. However, as Shenoutean studies began to gain momentum following Emmel's work, the study of monastic paideia — the intersection between monasticism and Greek education—also gained newfound interest and importance. Both advances have been an indispensable foundation for the present study.

Recent research on monastic paideia has been connected, in particular, with the research program "Early Monasticism and Classical Paideia" directed by Samuel Rubenson at Lund University. ${ }^{114}$ A recently published conference volume dedicated to this topic shows the breadth of approaches and sources. ${ }^{115}$ Other studies have focused on the educational system, ${ }^{116}$ such as the use of Homer and Menander in teaching writing and grammar (e.g., Anastasia Maravela's paper on school

${ }^{113}$ Leipoldt 1903.

${ }^{114}$ For more information, see the dynamic library and research tool Monastica: https://monastica.ht.lu.se, last accessed on December 7, 2021.

${ }^{115}$ Edited by Lillian L. Larsen and Samuel Rubenson under the title Monastic Education in Late Antiquity: Larsen and Rubenson (eds.) 2018. For the social situation of Shenoute's education and the Hellenistic influence on it, see Timbie 2016.

${ }^{116}$ For the overview of the schools and education in Egypt around Shenoute's time, see Timbie 2016: $37-39$. 
exercises from Western Thebes). ${ }^{117}$ However, while the authors of the volume discussed topics such as grammatical education, rhetorical education, and classical education, intertextuality and the authority of the intertexts in educational writings produced by monastic environments such as Shenoute's remain under-discussed.

Moreover, progress in studying biblical intertextuality in Shenoute's works was hindered by missing or inaccurate identifications of quotations and allusions. Émile Amélineau's work on half of the corpus of Canon 6 was conducted nearly a century ago during the early 20th century and is now outdated. ${ }^{118}$ Furthermore, his identifications of the quotations were incomplete; he often overlooked quotations or committed errors in the identification of biblical verses. In addition, in the Catholic tradition, he used the Latin Vulgate instead of the Septuagint or the often-incomplete Sahidic Coptic translation

Subsequently, Hermann Wiesmann translated Johannes Leipoldt's edition of some portions of Shenoute's works into Latin, ${ }^{119}$ which Timbie stated "may have slowed the modern study of

\footnotetext{
${ }^{117}$ Maravela 2018.

${ }^{118}$ Amélineau 1907 and 1914. For more detailed information on these volumes from his edition of
} Shenouteana, see Section 4.2.

${ }^{119}$ According to du Bourguet 1991: 2321, his manuscripts were mainly held in the Borgia Collection. 
Shenoute. ${ }^{, 120}$ However, her argument might be an oversimplification; in Germany or in France, it is more likely that anti-clericalism caused a lack of interest in Coptic studies in general, which slowed the development of Shenoutean studies, a sub-field of Coptic studies. Despite Timbie's criticism, Wiesmann's rich annotation of the sources of biblical quotations and allusions has provided a sound basis for the current study of intertextuality. However, the portion of Shenoute's works covered by Leipoldt's edition, and, consequently, Wiesmann's translation is relatively small compared to Amélineau's two volumes.

After Amélineau (1907 and 1914) and Wiesmann (1931 and 1936), a few scholars identified quotations and allusions in Canon 6. For example, in 2000 and 2002, Dwight Young's publications of unpublished pages from Shenoute's Canon 6 revealed intertextual relations through a high level of precise identification and annotation. Once again, however, the results were limited by his selection of

120 Timbie's 2015: 190 evaluation of the editions prepared by Amélineau 1907 and 1914 was as follows: “This edition has many mistaken transcriptions, grammatical mistakes, and misidentification of biblical quotations and allusions, yet it is still valuable because some of the texts have not been republished and because it has a modern language translation. Amélineau had previously published (with translation) a set of Coptic and Arabic texts related to Shenoute, but without analysis of the issues of authorship, historical accuracy, and so on [...]." Her judgment of Leipoldt and Wiesmann was more positive: "Leipoldt published many texts from the Borgia and Paris collections, correcting some defective readings while footnoting the text as it appears in the manuscript. This was very useful at an early stage in the study of literary Coptic and Coptic codicology. But only a Latin translation was published, and at a later date by Wiesmann 1931-1936, which may have slowed the modern study of Shenoute." 
texts. ${ }^{121}$ Finally, published in 2014, Bentley Layton's study of the Rules in the Shenoutean Monastic Federation only recorded outstanding intertexts in the footnotes, not all the intertexts ever found. ${ }^{122}$

It is only recently that the potential of related research has been reevaluated. In a study of quotations and allusions in He Who Sits Upon His Throne in Canon 6, Behlmer stated that, "in fact, Shenoute's consummate rhetorical mastery is most visible when he takes creative reuses of biblical texts. This appropriation of Scripture has long passed almost unnoticed." ${ }^{23}$ Schroeder made a similar point, which is discussed in more detail below. ${ }^{124}$

Recent studies of quotations and allusions found in Shenoute's works by Timbie and Behlmer covered only a fraction of the available texts. Behlmer explored Shenoute's rhetorical strategy in the first seven pages of MONB.XF, which encompasses the beginning of one of his works, He Who Sits Upon His Throne (i.e., the first work in Canon 6). ${ }^{125}$ She suggested that

[t]he quotations from the Psalms in He Who Sits Upon His Throne show once more the permanent interpretative actualization and recontextualization of Scripture that is characteristic of Shenoute's and

\footnotetext{
${ }^{121}$ Young 2000 and 2002.

${ }^{122}$ Layton 2014.

${ }^{123}$ Behlmer 2017: 320.

${ }^{124}$ Schroeder 2013: $20 f$.

${ }^{125}$ Behlmer 2017.
} 
many of his contemporaries' rhetorical repertoire. To understand the impact of the quotations we need to look at both their selection and their adaptation to the rhetorical needs of the situation. ${ }^{126}$

In addition, Behlmer concluded that,

[...] in summary, He Who Sits Upon His Throne once again shows how a skillful integration of the biblical text into the argument can seamlessly align Scripture along the main tenets of Shenoute's monastic ideology and interpretation of monastic discipline. ${ }^{127}$

In this limited extract from He Who Sits Upon His Throne, the language of the Bible was interwoven into Shenoute's educational rhetoric, as in his other works.

A larger study of quotations and allusions in Shenoute is required, possibly using a computational method of text reuse detection for scholars who have not thoroughly studied the Bible. For them, such a computation approach is less time-consuming and more effective than manual quotation and allusion detection relying on memory or concordances. Moreover, with the availability of new digital methods of detection and analysis, it seems a promising time to initiate a new search for quotations and allusions, and find new perspectives for their study. ${ }^{128}$ However, the chief advantage of digital tools is not that they are much more accurate than a trained biblical scholar but rather that the data is infinitely reusable. In other words, they can be used to integrate an ever-growing corpus of texts and discover every string of words, thus making it easier to discover idiomatic uses. Gaps in Shenoutean

\footnotetext{
${ }^{126}$ Behlmer 2017: 325 .

${ }^{127}$ Behlmer 2017: 327

${ }^{128}$ See Section 2.2.
} 
research can be thus addressed by applying the latest text reuse detection tools from digital humanities. $^{129}$

To have a solid basis for a further examination of the questions presented above, I utilized a digitally aided approach by running TRACER, the latest program for detecting text reuses (e.g., quotations, allusions, and more) on digital texts of Canon 6 and the Bible. Discovering unknown quotations and allusions also has valuable "side effects." Shenoutean Coptic is the largest source of Coptic texts written by a single author who was a native speaker of the language. Hence, these texts have a greater importance for the study of Coptic linguistics than other literary Coptic texts, which were translated from Greek. However, since Shenoute's works contained such a large number of quotations from the Bible (i.e., the Coptic translation of the OT and NT), it is important for linguists to distinguish between quotations and allusions on the one hand and Shenoute's own words on the other. Thus, this study is also expected to contribute to the field of Coptic linguistics in general.

A benefit from the study of quotations and allusions in Shenoute's writings can be gained for the study of the Coptic Septuagint. Various verses from the Sahidic Coptic translation of the Septuagint are attested only in quotations by Shenoute. As Boud'hors stated, the 16 verses of Lev 14:33-48 are only attested in Canon 8. In a discussion of monastic purity in the latter, Shenoute identified himself as

\footnotetext{
${ }^{129}$ See Miyagawa et al. (forthcoming).
} 
the priest of Leviticus. ${ }^{130}$ Horn listed quotationes (biblical quotations) as an essential source for reconstructing the Coptic biblical books. ${ }^{131}$ As such, Feder reconstructed Jer 2:21, 36; 9:19-21; 18:12; 23:9-10a, 28, and 40 based on quotations by Shenoute and Besa. ${ }^{132}$

Thus, the first step of this study-detecting all quotations and allusions - is expected to contribute to related fields, such as linguistics and Septuagint studies. The next chapter explores the development of the current study on intertextuality theories and text reuse detection technology as tools for studying biblical quotations and allusions in Shenoute's works.

${ }^{130}$ Boud'hors 2017: 769. In this work, Boud'hors also compared Shenoute and Besa's quotation style with that of Gnostic literature. For example, the Gnostic treatise Exegesis of the Soul quoted directly from the Greek Bible (translated into Coptic from Greek).

\footnotetext{
${ }^{131}$ Horn 2000: 103-04.

${ }^{132}$ Feder 2002a.
} 


\section{State of research}

This chapter presents an overview of current research on phenomena related to the research questions of this study, ${ }^{133}$ which ranges from methodologies to study intertextuality and text reuse to a more specific review of studies on intertextuality in biblical, patristic, and Coptic literature and, specifically, Shenoute's works. First, this chapter discusses types of intertextuality and their historical development, then reviews research on intertextuality and text reuse, its current state, general applications, classifications, systems of markup employed, and applications in biblical and patristic literature. Subsequently, the chapter discusses how intertextuality and text reuse research have been historically used in Coptic Studies, then specifically examines the same question in Shenoutean studies. Finally, the chapter explores how biblical quotations in Shenoute's works have been classified and how their characteristics have been described. Moreover, it discusses signal phrases for intertextuality and text reuse. Overall, the chapter introduces the defining features of Coptic and Shenoutean intertextuality, particularly with regard to quotations from the Bible.

${ }^{133}$ See Section 1.3. 


\subsection{Intertextuality}

\subsubsection{History and concept of intertextuality}

In general, to examine the ways in which people use quotations and the most common, popular, and usual forms of text reuse and intertextuality, inspiration may be taken from the works of Jorge Luis Borges (1899-1986), one of the 20th century's great Latin American writers who was at the same time highly influential in the fields of textual theory, narrative theory, and modern philosophy. His short story "Utopía de un Hombre que Está Cansado"134 contains a fascinating section about humans' use of quotations. In it, an English history professor named Eudoro Acevedo encounters a man who has supposedly been living in a house on the Pampas for 400 years. The man says to Eudoro Acevedo (who is the "I" in the following passage),

"[...] Man is master of his life. He is also master of his death."

"Is that a quotation?" I asked.

"Of course. Quotations are all we have now. Language is a system of quotations."

${ }^{134}$ Translated as "A Weary Man's Utopia" in English, this short story is included in the collection $E l$ Libro de Arena (Borges 2011), published in English as The Book of Sand (English translation: Borges 1977, 1979, and 2001).

${ }^{135}$ From an English translation by Norman Thomas di Giovanni; Borges 1979: 66. 
Such remarks could have been made by Borges directly. They clearly reflect his theory that every creative work is simply a patchwork that recycles previously created works.

Julia Kristeva, a Bulgarian-French philosopher, first used the term "intertextuality" in the 1960s. ${ }^{136}$ This term is rooted in the work of Russian textual theorist Mikhail Bakhtin, ${ }^{137}$ Ferdinand de Saussure's anagram studies, ${ }^{138}$ and Sigmund Freud's theories of psychology. Kristeva's theory of intertextuality states that no text is written or arises from nothing; it represents an amalgamation of various sections of extant works written by others. In a well-known passage, Kristeva explained her notion of intertextuality:

[...] tout texte se construit comme mosaïque de citations, tout texte est absorption et transformation d'un autre texte. ${ }^{139}$

Thus, in intertextuality theory, texts are regarded as a collage of parts of other texts. In intertextuality research, an analysis of the relationship between source texts and target texts and how

${ }^{136}$ Kristeva 1969. For the history of diverse studies on intertextuality, see Allen 2000.

${ }^{137}$ Bakhtin 1984 (an English translation of the Russian original). Kristeva was especially influenced by the concept of polyphony (Russian: полифония), which was developed in Bakhtin's analysis of Dostoevsky's poetics. For Dostoevsky, ways of seeing mirrored ways of conceptualizing. Bakhtin explored Dostoevsky’s "visual polyphony" and argued that, in polyphonic works, characters dialogued in various voices that echo and re-echo in a complicated and never-ending manner.

\footnotetext{
${ }^{138}$ See Juvan 2008: 100.

${ }^{139}$ Kristeva 1969: 84-85.
} 
the latter use the former is undertaken. A source text denotes the quoted, alluded to, or reused text, while the target text is the text that quotes from, alludes to, or reuses the source text. ${ }^{140}$

Kristeva was a student of Roland Barthes. In La Mort de l'Auteur ${ }^{141}$ (1967), Barthes proposed that no texts stemmed from an author's abilities or talents. Rather, they were created from extant works by other authors. This idea had a significant influence on Kristeva's theory of intertextuality. ${ }^{142}$ Although Kristeva's initial theory was novel and thought-provoking, it was too generic to cover every aspect of human creativity. By contrast, theories of intertextuality by various scholars who followed Kristeva (e.g., Gérard Genette, among others), offered greater detail and more abstract ways to clarify. ${ }^{143}$ Jean Ricardou examined the relationships between authors and texts, distinguishing between intertextualité générale, which denotes that Text 1 was written by Author A and that Text 2 was written by Author B, and intertextualité restreinte, which denotes that Text 1 was written by Author A and that

\footnotetext{
140 The distinction between source and target is a prevailing one in the field of cognitive linguistics,
} including conceptual metaphor theory (CMT). The terms "source" and "target" were introduced by Lakoff and Johnson in 1980; see Lakoff and Johnson 1980.

${ }^{141}$ In English, “The Death of the Author.” As its title indicates, Barthes's thesis in the book was influenced by Kristeva's definition of intertextuality.

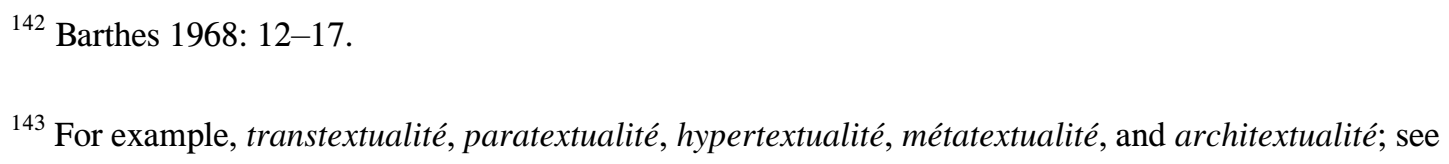


Text 2 was written by Author A. ${ }^{144}$ To these, Lucien Dällenbach added the concept of intertextualité autarcique, which represents intertextuality present in a single text. ${ }^{145}$

However, philologists whose field is the literature of the Bible may not regard such philosophical enquiries as suited to practical applications. For example, Per Rönnergård stated that he does not use intertextuality theory but conceded that certain concepts, such as Bakhtin's dialogic and polyphonic and Genette's hypertext and hypotext, have assisted his research. ${ }^{146}$

After Kristeva's study of intertextuality, scholars have developed many alternative descriptions, theories, and classifications related to this concept. Nevertheless, when intertextuality is considered in the practical arena, it is generally regarded as designating the hypertext of a quotation, an allusion, a paraphrase, a textual imitation, etc. This definition uses "intertextuality" and explores text reuse in a rather more basic and practical way in comparison with the complex and intellectually dense concepts

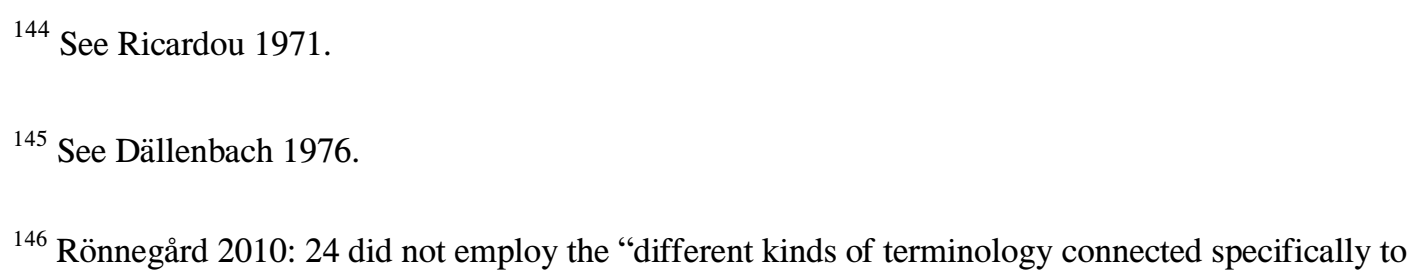
theorists of intertextuality." Thus, he stated that "[o]ne reason is that Julia KRISTEVA, the scholar who coined the term 'intertextuality' and whose work is the basis for much of the theory employing intertextuality which has followed, herself claims that it is at the end of the nineteenth century that 'the problem of intertextuality (intertextual dialogue) appears as such' [...] However, the proliferation within modern scholarship of concepts such as 'dialogic' and 'polyphonic' (Bakhtin), 'hypertext and hypotext' (Genette) and the use of the word 'text' as the meaning generated by intertextual relationships, has put its marks also on the present study." 
outlined above. Such practical types of intertextuality research are extremely useful for those who study literature, including biblical literature, and have ultimately become commonplace in digital humanities projects. Rather than pursuing further explorations of the theoretical study of intertextuality, this is the approach taken in the present study.

For example, searching abstracts from the meeting of the Society of Biblical Literature (SBL) held in San Antonio in 2016 using the text mining technique of frequency analysis reveals that there were 56 mentions of the term "intertextuality" and 173 mentions of the term "intertext."147 Additionally, it is clear that both terms were more frequently used from 2004 onwards. ${ }^{148}$

${ }^{147}$ This technique is also employed in the "distant reading" approach used in digital humanities. See Moretti 2000 and Jockers 2013.

${ }^{148}$ The following table contains the data used to make Figure 1. All of it was taken from https://www.sbl-site.org/meetings, last accessed on December 19, 2021. The meetings in 2020 and 2021 were excluded from this table because their numbers of the presentations are small due to the outbreak of COVID-19.

\begin{tabular}{|c|c|c|}
\hline Meeting & Frequency of "intertext" & Frequency of "intertextuality" \\
\hline SBL 2019 San Diego & 147 & 62 \\
\hline SBL 2018 Denver & 160 & 58 \\
\hline SBL 2017 Boston & 137 & 56 \\
\hline SBL 2016 San Antonio & 173 & 57 \\
\hline SBL 2015 Atlanta & 135 & 30 \\
\hline SBL 2014 San Diego & 98 & 30 \\
\hline SBL 2013 Baltimore & 110 & 26 \\
\hline SBL 2012 Chicago & 78 & 36 \\
\hline SBL 2011 San Francisco & 92 & 37 \\
\hline SBL 2010 Atlanta & 97 & 21 \\
\hline SBL 2009 New Orleans & 58 & 17 \\
\hline SBL 2008 Boston & 60 & 18 \\
\hline SBL 2007 San Diego & 52 & \\
\hline
\end{tabular}




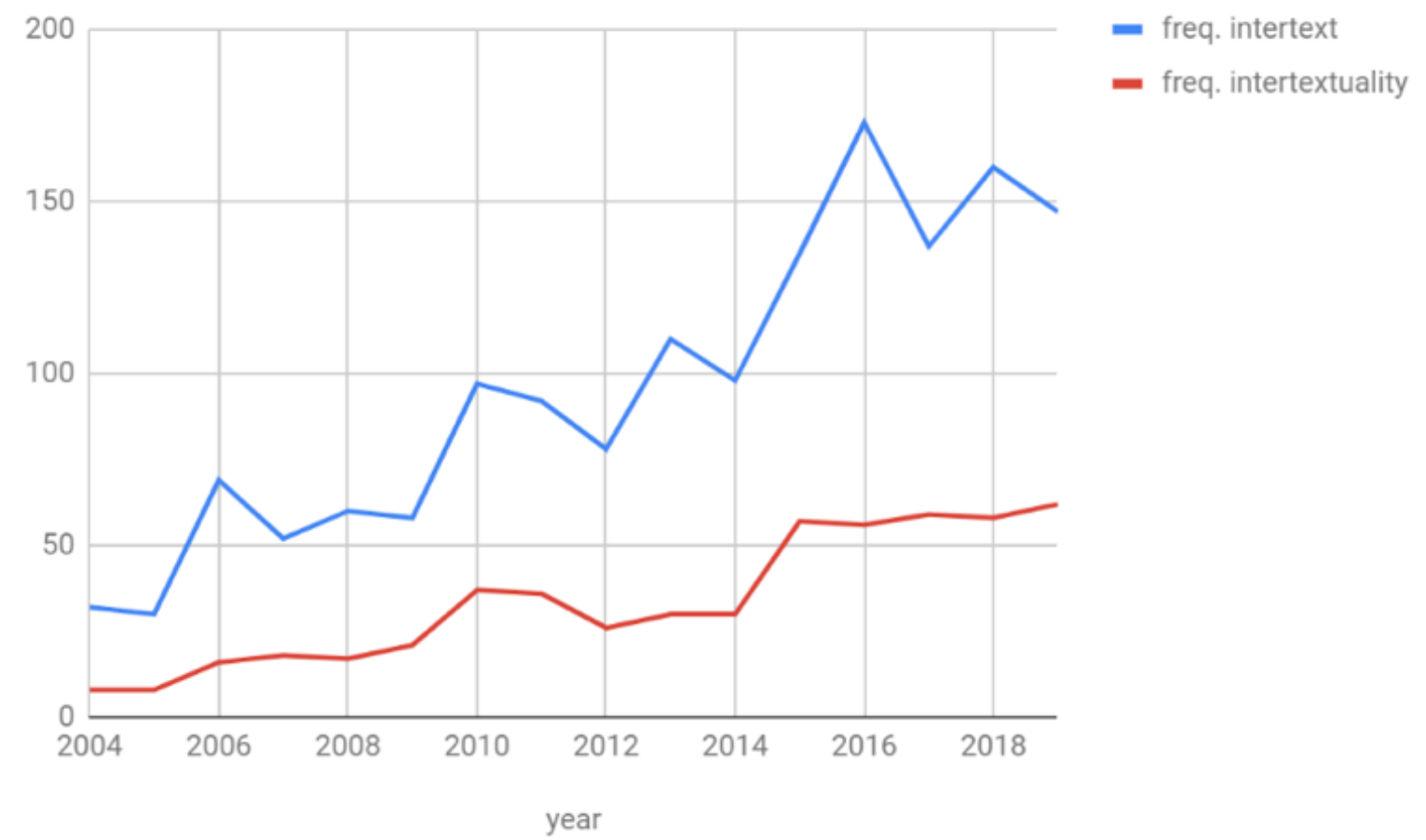

Figure 1: Gradual increase in the frequency of the term "intertextuality" in SBL meeting abstract books.

In addition, Google Books' Ngram Viewer shows that, while the term "intertextuality" rarely appeared in 1960s, it became increasingly common from the end of the 20th century onwards. While Figure 1 shows absolute frequency, Figure 2 shows relative frequency.

\begin{tabular}{|c|c|c|}
\hline SBL 2006 Washington, D.C. & 69 & 16 \\
\hline SBL 2005 Philadelphia & 30 & 8 \\
\hline SBL 2004 San Antonio & 32 & 8 \\
\hline
\end{tabular}




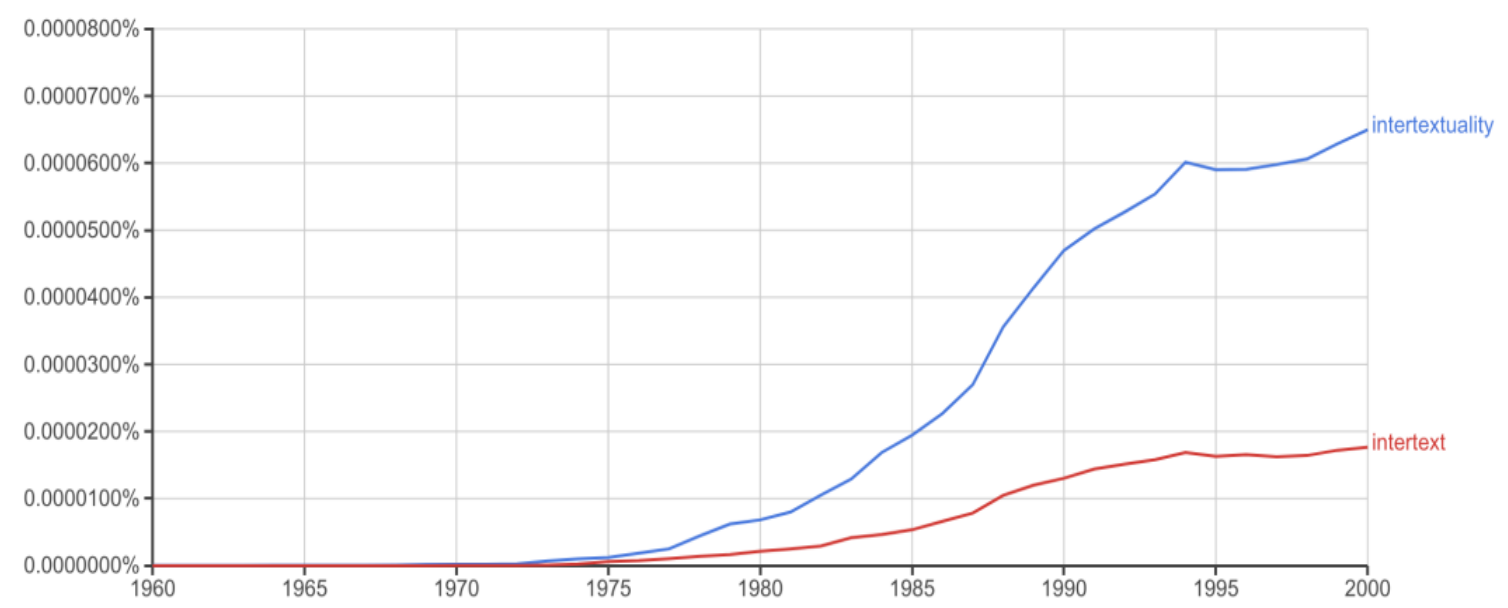

Figure 2: Increase in relative frequency of the terms "intertextuality" and "intertext" on Google Books. ${ }^{149}$

Both Figures 1 and 2 demonstrate that the terms "intertextuality" and "intertext" have become more common over the past few decades. This may indicate that intertextuality studies have also become more popular.

\subsubsection{Biblical intertextuality}

This subsection explores types of biblical intertextuality and initiates a discussion of early Coptic monastic literature, which extends over the next few subsections. Two main types of intertextuality are examined: intra-biblical (Subsection 2.1.2.1) and extra-biblical (Subsection 2.1.2.2). Extra-biblical intertextuality refers to any types of intertext from the Bible in non-biblical texts by a

${ }^{149}$ The link to the Google Books N-gram analysis can be found at https://books.google.com/ngrams/graph?content=intertextuality\%2Cintertext\&year_start=1960\&year_end=2000 \&corpus=15\&smoothing=3\&share=\&direct_url=t1\%3B $\% 2$ Cintertextuality $\% 3 \mathrm{~B} \% 2 \mathrm{Cc} 0 \% 3 \mathrm{~B} .11 \% 3 \mathrm{~B} \% 2 \mathrm{Cintertex}$ t\%3B\%2Cc0, last accessed on May 1, 2019. 
myriad of writers, including Shenoute. Both Manichaean texts (Subsection 2.1.2.2.1) and the Apophthegmata Patrum (Subsection 2.1.2.2.2) are used as examples in a scholarly discussion of extrabiblical intertextuality.

\subsubsection{Intra-biblical intertextuality}

This subsection focuses on typical examples of intertexts, such as quotations and allusions. First, it explores typical cases of intertexts in biblical books, which are among most studied works in intertexuality studies. ${ }^{150}$ In the NT, both allusions and quotations are frequently employed to reference the OT. The ways in which intertexts can be marked in modern translations of the Bible is illustrated in Figure 3.

${ }^{150}$ For example, reference of intertexts in the Bible is usually shown in footnotes or sidenotes of various annotated Bible editions, such as Figure 3. In addition, various works in this field have been published in anglophone Bible studies [e.g., see Schnittjer 2021 for intra-OT intertextuality, Dell and Kynes (eds.) 2016 for intra-biblical intertexuality in Ecclesiastes, Stead 2009 for Zechariah 1-8, Lee 2016 for Zechariah 9-10, Hibbard 2006 for Isaiah 24-27, Dell and Kynes (eds.) 2018 for Proverbs, Kynes 2019 for Job, Kynes 2012 for intertexts in Job from Psalms, New 1993 for quotations from the Septuagint in the Synoptic Gospels, Hays 2017 for intrabiblical intertextuality in the Gospels, Porter and Land (eds.) 2019 for intra-biblical intertextuality in the Pauline Letters, Bird and Willitts (eds.) 2011 for intertexts from the Gospels in the Pauline Epistles, and Crisler 2021 for intra-biblical intertextuality in the Letter to the Romans]. Recently, Evans et al. (eds.) 2020 focused on the concept of "textual interplay." 
offenbart?« 39Darum konnten sie nicht glauben, denn Jesaja hat wiederum gesagt (Jesaja 6,9-IO): $\mathbf{4 0}$ »Er hat ihre Augen verblendet und ihr Herz verstockt, damit sie nicht etwa mit den Augen sehen und mit dem Herzen verstehen und sich bekehren und ich ihnen helfe. « ${ }^{a}{ }^{41}$ Das hat Jesaja gesagt, ${ }^{a}$ weil er seine Herrlichkeit sah und redete von ihm. 42 Doch auch von den Oberen glaubten viele an ihn; aber um der Pharisäer willen bekannten sie es nicht, um nicht ${ }^{a}$ aus der Synagoge ausgestoßen zu werden. ${ }^{43}$ Denn ${ }^{a}$ sie hatten lieber Ehre bei den Menschen als Ehre bei Gott.

44 Jesus aber rief: Wer an mich glaubt, der glaubt nicht an mich, sondern an den, der mich gesandt hat. ${ }^{45}$ Und ${ }^{a}$ wer mich sieht, der sieht den, der mich gesandt hat. $46 \mathrm{Ich}$ bin in die Welt gekommen als ein ${ }^{a}$ Licht, damit, wer an mich glaubt, nicht in der Finsternis bleibe. 47 Und wer meine Worte hört und bewahrt sie nicht, den werde ich nicht richten; denn ${ }^{a}$ ich bin nicht gekommen, dass ich die Welt richte, sondern dass ich die Welt rette. 48 Wer mich verachtet und nimmt meine Worte nicht an, der hat schon seinen Richter: Das Wort, das ich geredet habe, das wird ihn richten am Jüngsten Tage. ${ }^{49}$ Denn ich habe nicht aus mir selbst geredet, sondern der Vater, der mich gesandt hat, der hat mir ein Gebot gegeben, was ich tun und reden soll. 50 Und ich weiß: sein Gebot ist das ewige Leben. Darum: was ich rede, das rede ich so, wie es mir der Vater gesagt hat.

\section{JESU ABSCHIEDSREDEN}

(Kapitel 13,I-I 7,26)

\section{Die Fußwaschung}

13 Vor dem Passafest aber erkannte Jesus, ${ }^{a}$ dass seine Stunde gekommen war, dass er aus dieser Welt ginge zum Vater; und wie er die Seinen geliebt hatte, die in der Welt waren, so liebte er sie bis ans Ende. 2 Und beim Abendessen, als schon ${ }^{a}$ der Teufel dem Judas, Simons Sohn, dem Iskariot, ins Herz gegeben hatte, ihn zu verraten, 3 Jesus aber wusste, dass ihm ${ }^{a}$ der Vater alles in seine Hände gegeben hatte und dass er bvon Gott gekommen war und zu Gott ging, ${ }^{4} \mathrm{da}$ stand er vom Mahl auf, legte sein Obergewand $a b$ und nahm einen Schurz und umgürtete sich. 5Danach goss er Wasser in ein Becken, fing an, den Jüngern die Füße zu waschen, und trocknete sie mit dem Schurz, mit dem er umgürtet war.

6Da kam er zu Simon Petrus; der sprach zu ihm: Herr, solltest du mir die Füße waschen? 7Jesus antwortete und sprach zu ihm: Was ich tue, das verstehst du jetzt nicht; du wirst es aber hernach erfahren. ${ }^{8} \mathrm{Da}$ sprach Petrus zu ihm: Nimmermehr sollst du mir die Füße waschen! Jesus antwortete ihm: Wenn ich dich nicht wasche, so hast du kein Teil an mir. ${ }^{9}$ Spricht $\mathrm{zu}$ ihm Simon Petrus: Herr, nicht die Füße allein, sondern auch die Hände und das Haupt! 10Spricht Jesus zu ihm: Wer gewaschen ist, bedarf nichts, als dass ihm die Füße gewaschen werden; denn er ist ganz rein. Und ${ }^{a}$ ihr seid rein, aber nicht alle. 11Denn er kannte seinen Verräter; darum sprach er: Ihr seid nicht alle rein.

$12 \mathrm{Als}$ er nun ihre FüBe gewaschen hatte, nahm er seine Kleider und setzte sich wieder nieder und sprach zu-ihnen: Wisst ihr, was ich euch getan habe? ${ }^{13} \mathrm{Ihr}$ nennt mich Meister und Herr und sagt es mit Recht, denn ich bin's auch. ${ }^{a}$ 14 Wenn nun ich, euer Herr und Meister, euch ${ }^{a}$ die FüBe gewaschen habe, so sollt auch ihr euch untereinander die $\mathrm{FüBe}$ waschen. ${ }^{15}$ Ein Beispiel habe ich euch gegeben, damit ihr tut, wie ich euch getan habe. ${ }^{a}{ }^{16}$ Wahrlich, wahrlich, ich sage euch: ${ }^{a}$ Der Knecht ist nicht größer als sein Herr und der Apostel nicht größer als der, der ihn gesandt hat. ${ }^{17}$ Wenn ihr dies wisst - selig seid ihr, wenn ihr's tut. ${ }^{a}$

18Das sage ich nicht von euch allen; ich weiß, welche ich erwählt habe. Aber es muss die Schrift erfüllt werden (Psalm 4I,IO): wDer mein Brot isst, tritt mich mit Füßen.« 19Jetzt sage ich's euch, ehe es geschieht, damit ihr, wenn es gesche-

I2,40: $a$ Mt 13,I4-15 I2,41: $a$ Jes 6,I I2,42: $a$ Kap 9,22 12,43: $a$ Kap 5,44 12,45: $a$ Kap I4,9 I2,46: $a$ Kap 8,12 I2,47: $a$ Kap 3,17; Lk 9,56 I3,I: $a \cdot \operatorname{Kap} 7,30 ; 17, \mathrm{I} \quad$ 13,2: $a$ Lk 22,3 I3,3: $a$ Kap 3,35; $b$ Kap I6,28 I3,10: a Kap 15.3 13,I3: $a$ Mt 23,8.10 13,I4: $a$ Lk 22,27 r3, r5: $a$ Phil 2,5; I. Petr 2,21 r3, r6: $a$ Mt ro,24 13,17: a Mt 7,24

Figure 3: Page 125 (John 12:39-13:19) of the Luther Bible (Deutsche Bibelgesellschaft 2008). 
There is a modernized translation of the Luther Bible published in $2017 .{ }^{151}$ The quotation of $\mathrm{Jn}$ 12:40, which will be discussed in Subsection 2.1.2.1.1, is divided by pages in the 2017 version, but not in the 2008 version. Therefore, the latter was chosen for Figure 3.

\subsection{Quotations}

In modern editions of the Bible, quotations or allusions are indicated in a footnote or a side note or directly referenced in the text, as illustrated in Figure 3. In John 12:37-40, Jesus avoids his audience after a sermon, and the writer states that the audience did not believe in him even though he had given them numerous signs. The author then quotes from the Book of Isaiah to show Isaiah's prophecy on Israelite infidelity had come to pass. In the following passage, John quotes Isaiah in two places:

$\underline{\text { Jn } 12: 37-40}$

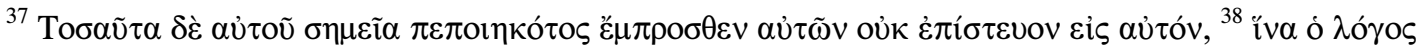

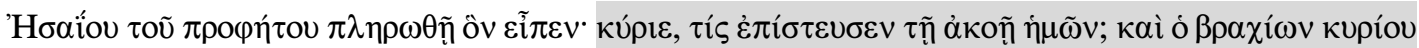

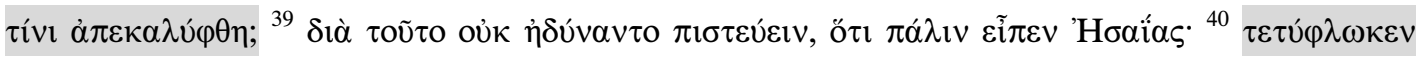
$\alpha$

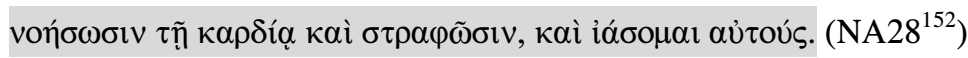

${ }^{151}$ Deutsche Bibelgesellschaft 2017: 125-26

${ }^{152}$ Aland et al. (eds.) 2012. 
${ }^{37}$ Though he had done so many signs before them, they still did not believe in him, ${ }^{38}$ so that the word spoken by the prophet Isaiah might be fulfilled: 'Lord, who has believed what he heard from us, and to whom has the arm of the Lord been revealed? ${ }^{39}$ Therefore they could not believe. For again Isaiah said, ${ }^{40}$ 'He has blinded their eyes and hardened their heart, lest they see with their eyes, and understand with their heart, and turn, and I would heal them.' $\left(\mathrm{ESV}^{153}\right)$

In this passage, there are two quotations highlighted in gray in the Greek text and the English translation. The author indicates that he is using a direct quotation from the Book of Isaiah by employing

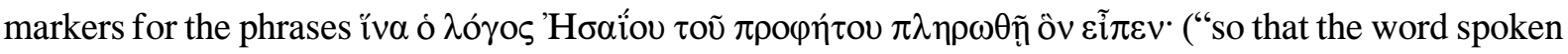

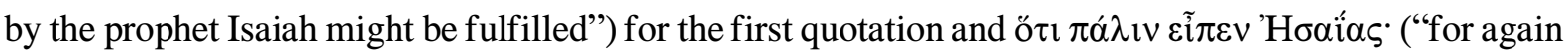
Isaiah said"). The markers indicate that this is, to all intents and purposes, a direct quotation. Nevertheless, the quotations have different characteristics. Jn 12:38, the first quotation in Jn 12:37-40, and its source text (Is 35:1) are as follows:

$\underline{\text { Jn } 12: 38}$

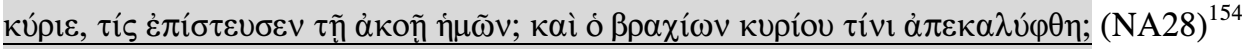
Lord, who has believed what he heard from us, and to whom has the arm of the Lord been revealed? $(\mathrm{ESV})$

${ }^{153}$ ESV Bible Translation Committee 2009; hereafter, this English translation of the Bible (the English Standard Version) is referred to as ESV.

${ }^{154}$ A quotation and the corresponding source are highlighted in gray. The shared morphs by the quotation and the source text are underlined. 


\section{Source: Is 53:1}

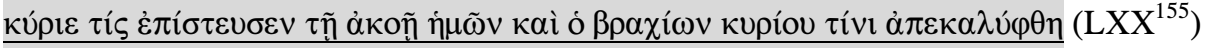

Lord, who has believed our report? And to whom has the arm of the Lord been revealed? (NETS ${ }^{156}$ )

The passage above shows text from the Septuagint and a translation. There is an exact match between the quotation and its source; thus, it can be inferred that the gospel author used a direct quotation. This type of quotation, in which the target and source texts exactly match, ${ }^{157}$ is commonly referred to as a verbatim quotation.

By contrast, Is 6:10, the source text of the second quotation (Jn 12:40) does not represent a

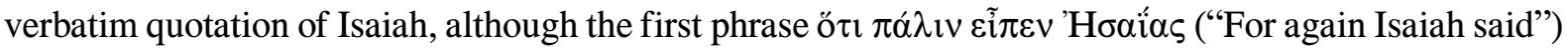
demonstrates that Isaiah should be identified as the source text.

$\underline{\text { Jn } 12: 40}$

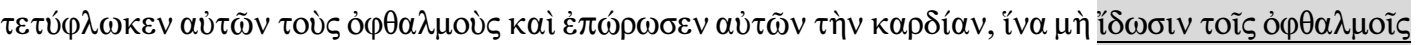

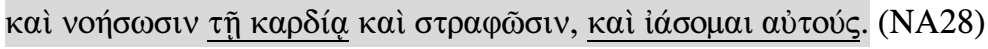

${ }^{155}$ The Septuagint (LXX) text was taken from Rahlfs and Hanhart eds. 2014. The original edition of Rahlfs and Hanhart eds. 2014 is Rahlfs ed. 1931.

${ }^{156}$ NETS stands for the New English Translation of Septuagint (Pietersma and Wright eds. 2007).

${ }^{157}$ Jn 12:40-41 and the Septuagint Greek translation for Is 53:1. 
"He has blinded their eyes and hardened their heart, lest they see with their eyes, and understand with their heart, and turn, and I would heal them." (ESV)

\section{Source: Is 6:10}

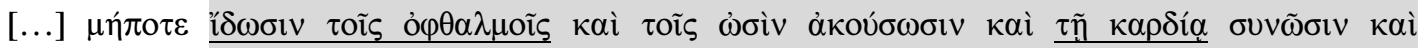

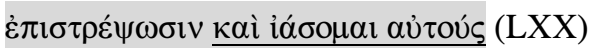

"[...] so that they might not see with their eyes and hear with their ears and understand with their heart and turn - and I would heal them.” (NETS)

Both quotations feature the same content, referring to those who cannot hear the voice of God because of their hard hearts and blind eyes, but the morphs shared by Jn 12:40 and Is 6:10 are í $\delta \omega \sigma \mathrm{vV}$

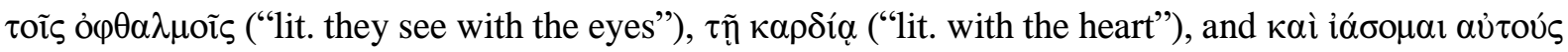
("lit. and I would heal them"). There are three synonymous alternations: $\mu \eta \dot{\pi o} \tau \varepsilon$ ("lest") in Is $6: 10 \rightarrow$

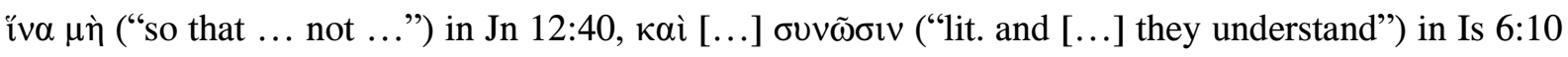

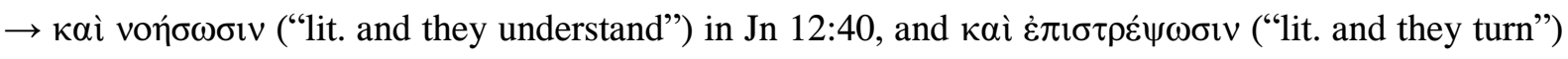

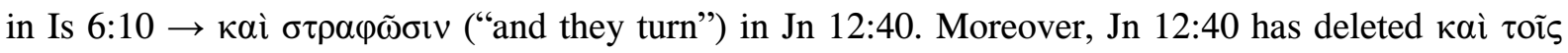

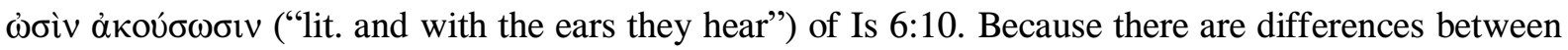
the quotation and the source, Jn 12:40 is not a verbatim quotation of Is 6:10, but rather a near-verbatim quotation. 


\subsection{Allusions}

After the quotation, the second most common type of intertext is the allusion. Many examples of allusions can be found in every part of the Bible. The English Standard Version, as many other versions of the Bible, states that Hebrews 11:5 contains an allusion to Gen 5:24:

\section{Heb 11:5}

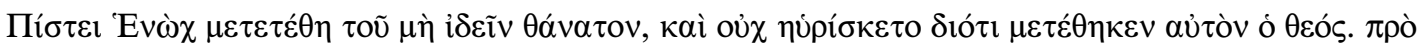

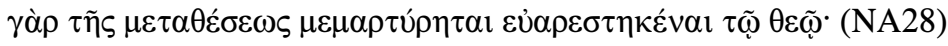

By faith Enoch was taken up so that he should not see death, and he was not found, because God had taken him. Now before he was taken he was commended as having pleased God. (ESV)

\section{Source: Gen 5:21-24}

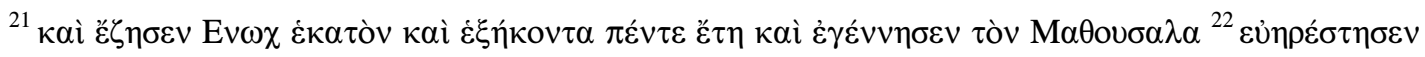

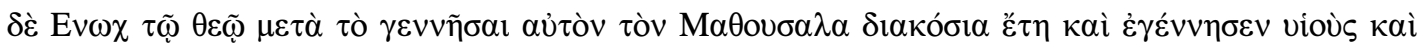

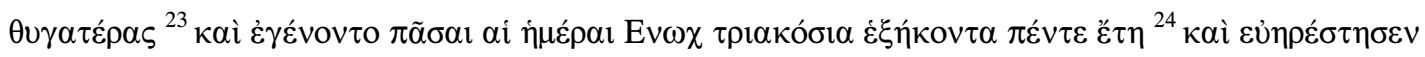

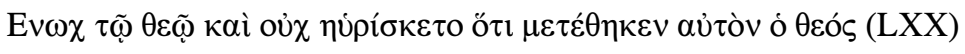

${ }^{21}$ And Henoch lived one hundred sixty-five years and became the father of Mathousala. ${ }^{22}$ Now Henoch was well pleasing to God after he became the father of Mathousala, for two hundred years, and had sons and daughters. ${ }^{23}$ And all the days of Henoch amounted to three hundred sixty-five years. ${ }^{24}$ And Henoch was well pleasing to God, and he was not found, because God transferred him. (NETS) 
In this case, the author of Hebrews is alluding to the story of Enoch. Nevertheless, unlike with quotations, the source text for an allusion is not always clear. Regarding Enoch, the source text may be Genesis 5:24 but it could also be the Book of Enoch or oral traditions about this figure. When a quotation is lifted more or less entirely from a known parallel text, its source can be confidently identified. By contrast, it is much more difficult to determine this if a text contains an allusion to a lost or obscure source. Moreover, allusions frequently neglect to mention the source text.

When a quotation is almost verbatim and the source text can be found, it can be said with some confidence that the latter is most likely the source of the quotation. This is not always the case with allusions, as the target text does not have a parallel source. Ambiguous sources are one of the features of allusion. As in the allusion to Gen 5:21-24 in Heb 11:5, they differ from quotations in that they do not credit their sources, even when they have been lifted from a text written by another author.

\subsubsection{Extra-biblical intertextuality}

The next two subsections consider two examples of extra-biblical intertextuality from Manichaean literature (Subsection 2.1.2.2.1) and the Apophthegmata Patrum (Subsection 2.1.2.2.2). The Bible is undoubtedly the most quoted book in the Christian literature, including those of Late Antiquity. Moreover, biblical intertextuality has been studied in both Christian and non-Christian writings. 


\subsection{Manichaean literature}

In two recent books, Nils Arne Pedersen, René Falkenberg, Claudia Leurini, and John Møller Larsen listed biblical intertexts in Manichaean literature, covering sources with links to Manichaeism in New Persian, Arabic, Middle Persian, Parthian, Syriac, Greek, Sogdian, and Coptic. ${ }^{158}$ Alongside texts of Manichaean authorship, the books also covered anti-Manichaean writings (e.g., Islamic and Christian authors). Pedersen et al. distinguished only three forms of intertext: allusion (A), vague allusion (A?), and quotation (C). Vague allusions were found to be the most frequent type. ${ }^{159}$ Most cases of A? were extremely doubtful and, in numerous instances, may not have been allusions at all. There are two types of questionable allusions: (1) possible allusions to more than one source and (2) general idiomatic usage.

Below is an example of a quotation from the Manichaean Psalm-Book II 66,14-15, which Pedersen et al. categorized it as a vague allusion (A?), recognizing two possible sources: Ps 17:32 (18:32) and Is 44:6.

$\underline{\text { A? Psalm-Book II 66,14-15 }}{ }^{160}$

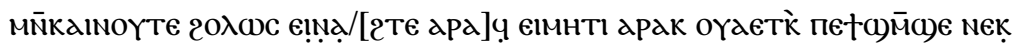

${ }^{158}$ Pedersen et al. 2017 listed all possible intertexts from the OT in the Manichaean literature, and Pedersen et al. 2020 did the same for the NT.

${ }^{159}$ Pedersen et al. 2017.

${ }^{160}$ The classification of the vague allusion to Ps 17:32 (18:32) are taken from Pedersen et al. 2017: 111. 
There is no other god at all in whom I believe, except you alone whom I serve. ${ }^{161}$

$\underline{\text { Possible allusion source: Ps 17:32 (18:32) }}^{162}$

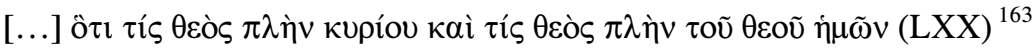

[...] because, who is god except the Lord? And who is god besides our God? (NETS)

\section{Another possible allusion source: Is 44:6}

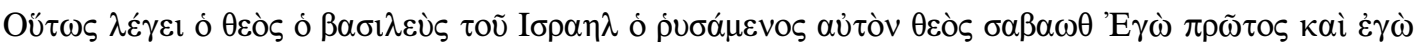

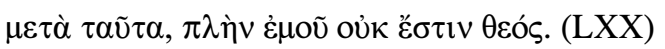

"Thus says God, the king of Israel, who delivered him, God Sabaoth: I am first, and I am after these things; besides me there is no god." (NETS)

Although Pedersen et al. identified Psalm-Book II 66,14-15 as a possible allusion to Ps 18:32 or Is $44: 6$, the source could also be Dtn 32:39. As such, the Bible itself contains various intra-biblical intertexts, and it is difficult to determine the ultimate source. Thus, modern readers cannot confidently determine the exact source of the quotation if the source itself quotes another part of the Bible.

${ }^{161}$ Text and translation adapted from Allberry 1938: 66 by Pedersen et al. 2017: 111.

${ }^{162}$ Pedersen et al. 2017: 11. The chapter and verse numbers are given according to the Septuagint. The numbers in parentheses are the chapter and verse numbers of the Masoretic Text.

${ }^{163}$ Pedersen et al. 2017 used the Revised Standard Version (RSV) of the Bible throughout their work. However, for the OT sections, this English translation of the Bible is based on the Hebrew Bible. The phrase from Psalm-Book II 66,14-15 is closer to the Greek Septuagint. 
The next example from Pedersen et al.'s study is also a problematic case in which the source of the quotation could not be decisively identified because condemning worshipers of celestial bodies was common in Judeo-Christian literature. Because the author neither specified that the passage was a quotation nor the title of the source text, researchers cannot be confident that the source is the Bible.

\section{A? Short Renunciation Formula 290}

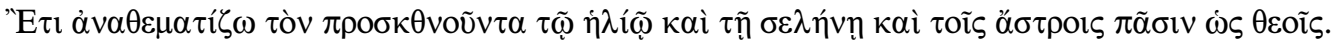

"Furthermore, I anathematize him who worships the sun and the moon and all the stars as gods."

$\underline{\text { Less plausible allusion to Gen } 1: 16^{165}}$

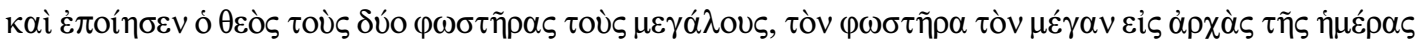

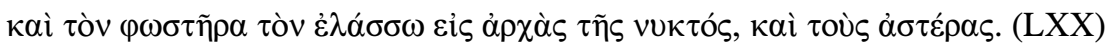

"And God made the two great luminaries, the great luminary for rulership of the day and the lesser luminary for rulership of the night, and the stars." (NETS)

The second passage may not actually contain an allusion, as the text on which it is supposedly based only mentions those who worship celestial bodies. By contrast, Genesis only refers to the creation of celestial bodies.

${ }^{164}$ Pedersen 2017: 5; the Greek text was taken from Ficker 1906: 447. The English translation was adapted from Lieu 1999: 299.

${ }^{165}$ Pedersen et al. 2017: 5. 
The biblical intertextuality taxonomy employed by Pedersen et al. is quite rudimentary compared to the one used by Per Rönnegård in his study on the Apophthegmata Patrum, which is more refined and features an extended range of categories.

\subsection{Apophthegmata Patrum}

Rönnegård created a system for categorizing biblical allusions and quotations in the Apophthegmata Patrum. He established four categories of biblical intertextuality: quotations, paraphrases, allusions, and unclear uses. Allusions and quotations were further divided into subcategories, which primarily depended on the presence or absence of an indicator. Rönnegård's taxonomy is as follows: ${ }^{166}$

1. Quotation

a. with a biblical quotation indicator such as "as it is written"

b. without a biblical quotation indicator, with distinctly biblical wording, longer than just a phrase of two or three words

c. liturgical quotation with an indirect biblical quotation indicator (e.g., “... so that you may be able to say: 'Forgive us our trespasses ...”’)

2. Paraphrase: ${ }^{1}$ a biblical text (a narrative or a statement) freely retold, not using the biblical wording but indicating a specific Bible passage

a. with a biblical paraphrase indicator (e.g., "... as was promised through the prophet Isaiah”)

\footnotetext{
${ }^{166}$ This list is an abridged summary of the classification of Rönnegård 2010: 26-28. The examples are
} Rönnegård's. 
b. without a biblical paraphrase indicator

3. Allusional use of a proper noun or a distinctly biblical concept, indicating a biblical event, monologue, or dialogue without directly describing it (e.g., "the words of the tax-collector")
a. with a biblical allusion indicator (e.g., "Scripture says...")
b. without a biblical allusion indicator

4. Less clear use of the Bible:

a. Other types of biblical allusions using words or structures from a specific Bible passage

b. Vague allusions to a biblical concept or metaphor (e.g., "the King's Highway")

c. Other types: biblical ideas, patterns, expressions, or concepts inspired by the Bible (e.g., "You have heard ... but I tell you").

While Rönnegård's work may be regarded as referring to intertextuality, he does not specifically mention it as being foundational to his research and indeed only uses the term six times on a single page. $^{167}$

In contrast to Pedersen et al. and Rönnegård, who primarily classified biblical intertextuality from a formal perspective while employing indicators or measurements of whether a text is a verbatim match, Frances Young offered a classification from a functional perspective and argued for the importance of context. She proposed that scholars have frequently ignored perfect integrity with a quotation's original context and viewed the original theme signposted by the quotation as a symbolic token or mimesis. Thus, Young offered a classification of biblical quotations in accordance with the role

\footnotetext{
${ }^{167}$ Rönnegård 2010: 24.
} 
that they play in discourse. ${ }^{168}$ This mimetic reading differs from readings that categorize intertextuality in a formal manner. The following list represents Rönnegård's summary of Young’s classification: ${ }^{169}$

(1) Paraenetic reading; (2) Oracular exegesis; (3) Lexical analysis; (4) Explanatory comment; (5) Deductive expansion; (6) Mimetic reading: (a) for exemplary paraenesis; (b) to provide prophetic "types"; (c) to see how the text mirrors reality iconically; ${ }^{170}$ (d) to uncover the underlying truth symbolically.

Paraenetic reading refers to the use of biblical texts as a part of moral teaching, oracular exegesis to the use of biblical text as a riddle or an oracle, and mimetic reading refers to the form that Young most heavily focused on - namely, that a biblical quotation is read in such a way that it reflects the reader's reality.

\footnotetext{
168 Young 1997: 212.

${ }^{169}$ Young 1997: 212. Also, Rönnegård 2010: 20-21 discussed this classification.

${ }^{170}$ Originally, Young 1997 uses the spelling “ikonically" and "ikonic" throughout her book (Young 1997: 157, 161, 162, 165, 169, 175, 184, 200, 210, 211, 212, and 295). Young 1997: 184 states, "Ikonic
} exegesis, I suggest, implies some kind of genuine representation, by contrast with symbolic exegesis where the symbols are signs and tokens." 


\subsubsection{Biblical intertextuality in non-textual formats}

Intertextuality is not only present in "texts" in the rigid sense but can also be applied more widely to film, music, art, and industrial design. Indeed, it is present in all human creative activities. ${ }^{171}$ Modern creative works that contain biblical allusions widely vary, and intertextuality is globally present, even in countries without substantial Judeo-Christian traditions (e.g., Japan). For example, the stillpopular anime series Neon Genesis Evangelion, a television series with several manga and film spinoffs, contains allusions to apocryphal literature and the Bible. ${ }^{172}$ In this series, an apocalyptic being is driven by Judeo-Christian moral considerations and religious principles such as the search for salvation, and there are numerous references to stories from the same tradition. Annette Y. Reed stated, ${ }^{173}$

Names of angels, demons, and otherworldly realms have been culled from NT apocrypha and OT pseudepigrapha for reuse in and across story lines about imagined futures and cosmic realities-

${ }^{171}$ For example, Franzini et al. 2016 gave the example of a modern reproduction of Vermeer's 1655 painting "Girl with a Pearl Earring" in the 2003 film version, in which the actress Scarlett Johansson poses like the girl in the original painting.

${ }^{172}$ Neon Genesis Evangelion was produced by GAINAX and directed by Hideaki Anno. It was broadcast on TV Tokyo from 1995 to 1996. Its popularity persisted after its original broadcast run; new movies were released in 2007 [Evangelion: 1.0 You Are (Not) Alone], 2009 [Evangelion: 2.0 You Can (Not) Advance], 2012 [Evangelion: 3.0 You Can (Not) Redo], and 2021 (Evangelion: 3.0+1.0 Thrice Upon a Time).

${ }^{173}$ Reed 2015: 419. 
sometimes alongside fresh twists on Japanese folklore about foxes, forest spirits, and hungry ghosts, and sometimes entwined with modern mythologies of robots and aliens.

In the Evangelion series, giant robotic human clones created by an organization called NERV fight the angels that attack NERV headquarters; the organization is independent but operates with United Nations funding to defend humanity against the angels. ${ }^{174}$ In this narrative, NERV keeps the Fruit of the Tree of Life underground in its headquarters. SEELE, an underground organization that controls the angels, attempts to steal it. During the series' culmination, an Evangelion obtains the Tree of Life and becomes a God-like supreme being. Clearly, the Fruit of the Tree of Life alludes to Gen 2:4-3:14. Even if the show's biblical subtext is not made explicit, such phrases tap into viewers' broader common knowledge to create a story with a different cultural horizon but that uses familiar motifs.

Allusions can be made not only to a textual passage but also to a genre. For example, there is an illustrated collection of translations from the Apophthegmata Patrum called Desert Wisdom: Sayings from the Desert Fathers. ${ }^{175}$ In this book project from 2001, the Desert Fathers and Mothers are portrayed as Buddhist monks and nuns who wear the typical kesa dress of Japanese Zen Buddhists rather than Egyptians living alone or in ascetic communities in the desert or the Nile Valley. Their depictions closely

\footnotetext{
${ }^{174}$ In the original Japanese, the Angels are called shito ("Apostles"), not tenshi ("angels").

${ }^{175}$ Nouwen and Nomura 2001. Yushi Nomura translated these from Migne's Greek edition, taking
} inspiration from a lecture by Henri Nouwen (1932-1996) at Yale Divinity School. Nouwen was a Dutch catholic priest who held professorships at the University of Notre Dame, Yale Divinity School, and Harvard Divinity School. As for the "Desert Fathers and Mothers," see Ward 2003. 
resemble Japanese Zen paintings. Thus, the characters in the book are - living in Egypt from the third to the mid-fifth centuries - portrayed as if they are Buddhist monks and nuns from koan and zenna, ${ }^{176}$ short stories used by Zen Buddhist instructors and educators. ${ }^{177}$ The illustrations allude to famous historic Zen masters and create the impression that the Desert Fathers and Mothers possessed a similar wisdom to the Oriental philosophy held by these masters.

It is only recently that intertextuality has begun to be extensively, almost opening what might be called a new field within literary and cultural studies. However, the recognition of intertextuality existed before the development of the modern concept. Indeed, intertextual marking dates back many centuries.

\subsubsection{Intertexts from unknown sources}

Sometimes, the source text of a quotation is unknown. For example, in the upper left-hand corner of a painting by Paul Gauguin from 1897-1898, there is a written title: 'D'où Venons Nous/Que

\footnotetext{
${ }^{176}$ Some typical examples of this style are Mumonkan ("The Gateless Gate") or Hekiganroku ("The
} Record of Blue Cliff").

${ }^{177}$ This analogy was also discussed by Harmless 2004: 471-72. For a comparison between Early Christianity and Buddhism, see Boisvert 1992. 
Sommes Nous/Où Allons Nous. ." 178 According to Kenji Tsutsui, this title echoes ancient texts by writers such as the first-century poet Persius and the late second-century Valentinian Gnostic philosopher Theodotus. ${ }^{179}$ Clement of Alexandria also quoted the following passage from Theodotus's Excerpts:

God made us, having previously no existence. For if we had a previous existence, we must have known where we were, and how and why we came hither. But if we had no pre-existence, then God is the sole author of our creation. As, then, He made us who had no existence, so also, now that we are made, $\mathrm{He}$ saves us by His own grace, if we show ourselves worthy and susceptible; if not, He will let us pass to our proper end. For He is Lord both of the living and the dead. ${ }^{180}$

The line "we must have known where we were, and how and why we came hither" has parallels with the inscription on Gauguin's painting. However, according to Kenji Tsutsui, it is unlikely that Theodotus was the origin of the question. Persius (34-62 CE) made a similar argument in Satires 3:66-

178 This painting is preserved at the Museum of Fine Arts, Boston, Acc. no. 36.270, under the English title "Where Do We Come From? What Are We? Where Are We Going?"

${ }^{179}$ Tsutsui 2004: $§ 1$.

${ }^{180}$ Theodotus, Excerpts from Theodotus, paragraph 17 (this work has no chapter). The quoted English translation is from Wilson 1886. 
72. ${ }^{181}$ Furthermore, the same phrase is cited in Augustine's De Civitate Dei 2:6. ${ }^{182}$ Tsutsui contended that the specific source text cannot be identified and that the similarities result from the general philosophical background of the first and second centuries CE. In such instances, it may be impossible to identify the source texts for allusions or even direct quotations.

\subsection{Digital text reuse detection}

Intertextuality studies generally employ concepts such as quotation and allusion, developed by scholars in the humanities. This study combines practical text reuse detection methodology with computational tools and humanistic intertextuality analysis, as is often seen in research on digital

${ }^{181}$ From Tsutsui 2004: §1. Perseus, Satires, 3:66-72: “Listen, you poor unfortunates, and learn the purpose of human existence — what we are, what kind of life we are born to live; which is our lane, where the turn, and when to begin it; how much money's enough, what prayers are right, what advantage are crisp notes, how much should be set aside for the state and for your nearest and dearest; what role the lord has asked you to play, what post you have been assigned in the human service" (translated by Niall Rudd; see Rudd 2005: 146).

${ }^{182}$ From Augustine, De Civitate Dei, Book II, chap. 6:"'Be taught, ye abandoned creatures, and ascertain the causes of things; what we are, and for what end we are born; what is the law of our success in life; and by what art we may turn the goal without making shipwreck; what limit we should put to our wealth, what we may lawfully desire, and what uses filthy lucre serves; how much we should bestow upon our country and our family; learn, in short, what God meant thee to be, and what place He has ordered you to fill" (translated by Marcus Dods; see Dods 1887). 
humanities. While Chapter 2 discusses the history of both these methods, Chapter 3 explains the method used in this study more in detail. The following section briefly clarifies the taxonomy used for this dissertation and compares it with those of Pedersen et al. ${ }^{183}$ and Rönnegård ${ }^{184}$ (see Subsections 2.1.2.2.1 and 2.1.2.2.2).

\subsubsection{Text reuse in computer science}

As demonstrated in the examples from Subsection 2.1.2.2, various humanities scholars, including Rönnegård and Pedersen et al., have produced classifications of intertexts from a formal perspective. Instead of "intertext," computer scientists have used the term "text reuse." The intertext and text reuse are synonyms of different origins with a slight difference. Text reuse is a parallel text between two texts, but it does not necessarily specify the directionality of the reuse from the source to the target, whereas the intertext assumes the source and the target. That is, text reuse is a broader concept than the intertext, even covering idiomatic phraseology shared by two texts such as "beat around the bush." It is possible that one text in a text reuse pair quotes the other, or vice versa; that both texts have a common source (i.e., a different, third text); or that the text reuse is an idiom (which computer scientists call an "idiomatic text reuse") that is frequently used in a language or culture.

\footnotetext{
${ }^{183}$ See Pedersen et al. 2017.

${ }^{184}$ See Rönnegård 2010.
} 


\subsubsection{Text reuse taxonomy for the digital humanities used in}

\section{TRACER}

In computer science, text reuse detection technology was developed independently from intertextuality studies, mainly to detect plagiarism. ${ }^{185}$ Nevertheless, the concepts and range of text reuse and intertextuality overlap. ${ }^{186}$ Therefore, text reuse has been regarded as a synonym of intertextuality. ${ }^{187}$ Studies of text reuse in computer science have produced useful taxonomies in formative examples of reusing existing text. Research on the detection of text reuses arose from investigations on data mining in computer science, in which it was necessary to create categories of text reuse to assist computation.

One example is TRACER, ${ }^{188}$ which provides categories for types and subtypes of text reuse that can be used for detailed analyses (see Figure 4).

\footnotetext{
${ }^{185}$ See Bär et al. 2012.

${ }^{186}$ See Coffee et al. 2012.

${ }^{187}$ Forstall and Scheirer 2019: 55-56 regarded "[t]ext reuse as intertextuality."

${ }^{188}$ For details about TRACER, see Subsection 3.2.2.
} 


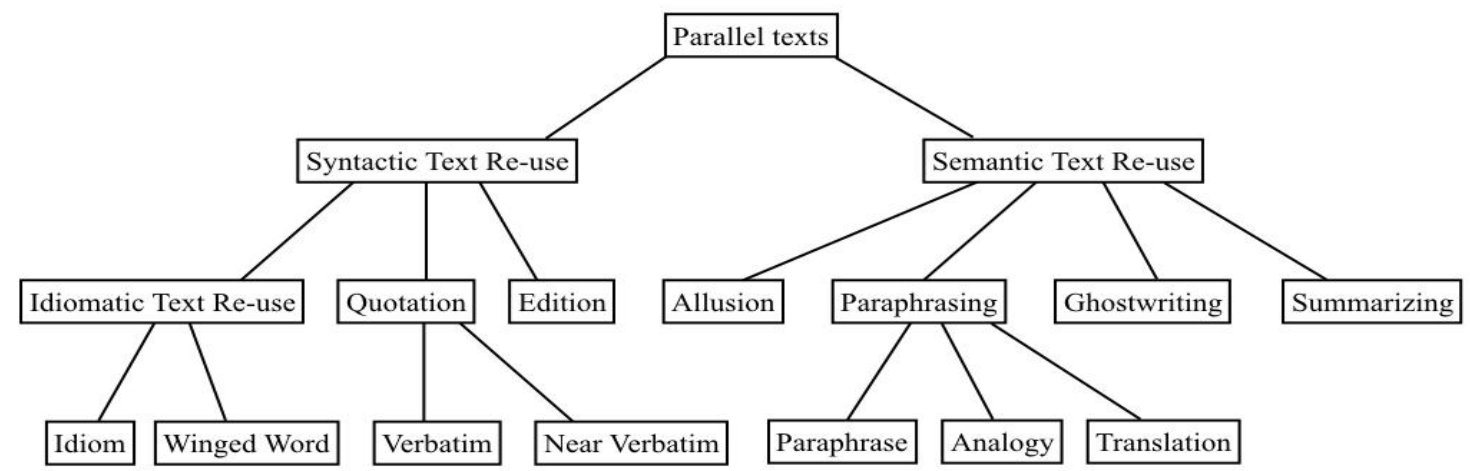

Figure 4: Taxonomy of text reuse in TRACER. ${ }^{189}$

TRACER categorizes paraphrases as semantic text reuses and quotations as syntactic text reuses. ${ }^{190}$ This appears to be an accurate categorization, because a quotation employs a source text in its original form, while a paraphrase conveys the same general meaning as the source text but in a different form. Nevertheless, the semantics of a quotation are identical in both target and source texts, although pragmatics may be different. Additionally, morphology, phonology, and syntax fall under the same category of syntactic text reuse. By contrast, semantic text reuses imply various forms of phonology, morphology, and syntax that differ from the original source. Therefore, syntactic text reuses are more visible and more easily identifiable than semantic text reuses.

189 This figure is based on Büchler 2013: 77, modified by Franzini et al. 2016, also adjusted in Miyagawa et al. (forthcoming).

190 TRACER's text reuse taxonomy and biblical text reuses in Shenoute and Besa were also discussed in Miyagawa and Behlmer (forthcoming a and b), and Miyagawa et al. (forthcoming). 
The taxonomic tree of text reuse forms shown in Figure 4 has its antecedents in Marco Büchler's doctoral thesis (Figure 5), ${ }^{191}$ which provided the basis for the work of Franzini et al. ${ }^{192}$ Additionally, Büchler categorized ciphering and patchwriting as parts of syntactic text reuse. ${ }^{193}$ This is not explored in this study, as syntactic text reuse is not its focus. Büchler offered additional types of text reuse and described their distinguishing features. ${ }^{194}$

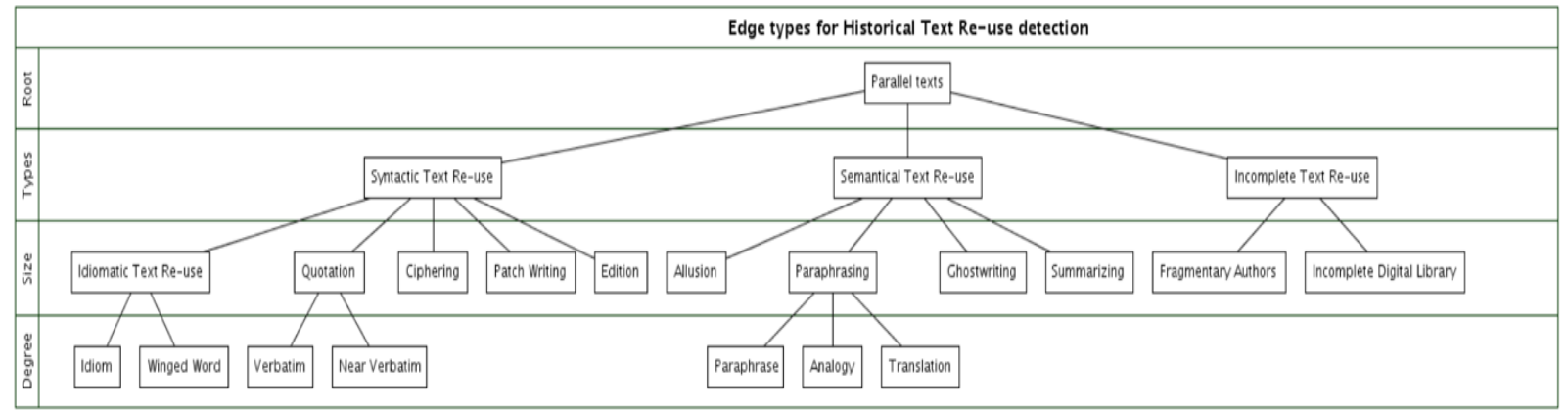

Figure 5: Büchler's original taxonomy of major text reuses. ${ }^{195}$

\footnotetext{
${ }^{191}$ Büchler 2013: 77.

${ }^{192}$ Franzini et al. 2016.

${ }^{193}$ Büchler 2013: 77.

${ }^{194}$ There are 43 additional types of text reuse. For more detail and a complete list of types, see Büchler
} 2013: 71-72.

195 Büchler 2013: 77. 


\subsubsection{Before TRACER - text reuse detection studies for non-}

\section{humanist uses}

Potthast, as well as Kirner-Ludwig and Zimmerman, have also suggested taxonomies of text reuse or reference, with an emphasis on plagiarism. Potthast's taxonomy is more computer scienceoriented text (see Figure 6) compared to Franzini et al.'s taxonomy, which targets both computer science and intertextuality studies as a digital humanities approach (see Figure 4).

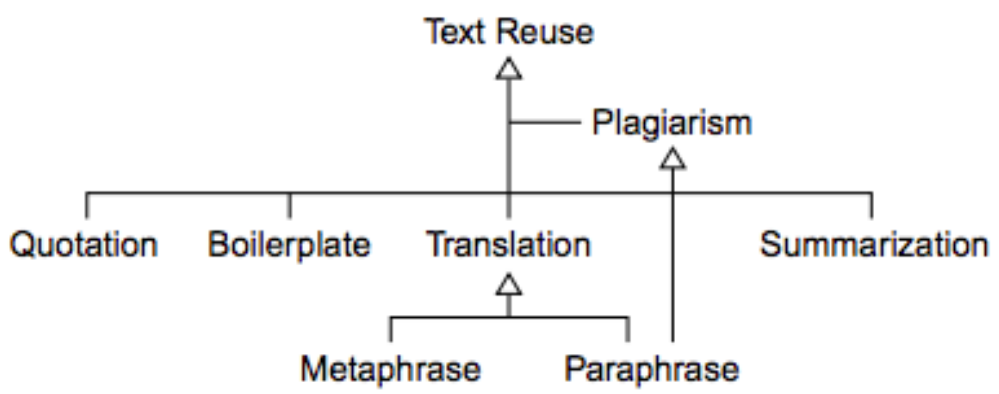

Figure 6: Potthast's taxonomy of text reuse. ${ }^{196}$

Potthast's taxonomy places plagiarism above all other text reuses. As such, Potthast's research relates to the practical detection of text reuse on the Internet to identify plagiarism. He mentioned that quotations, translations, paraphrases, metaphrases, summaries, boilerplate text, and plagiarism can be grouped under the term "text reuse." Moreover, he highlighted that many text reuses are often generally

196 Potthast 2012: 2. 
overlooked because of a lack of tools to detect them. ${ }^{197}$ This argument is especially true for texts written in ancient or medieval languages such as Coptic, while text reuses in modern languages with large speaker populations tend to be easily identified through plagiarism detection technology.

Potthast, who does not consider consistencies of form and semantics, offers a much less complex taxonomy of text reuse than TRACER. This makes it less useful for the purposes of this study; the same applies to Kirner-Ludwig and Zimmerman's taxonomy. They do not employ the term "text reuse" but rather "reference." For comparison, their taxonomy is shown in Figure 7.

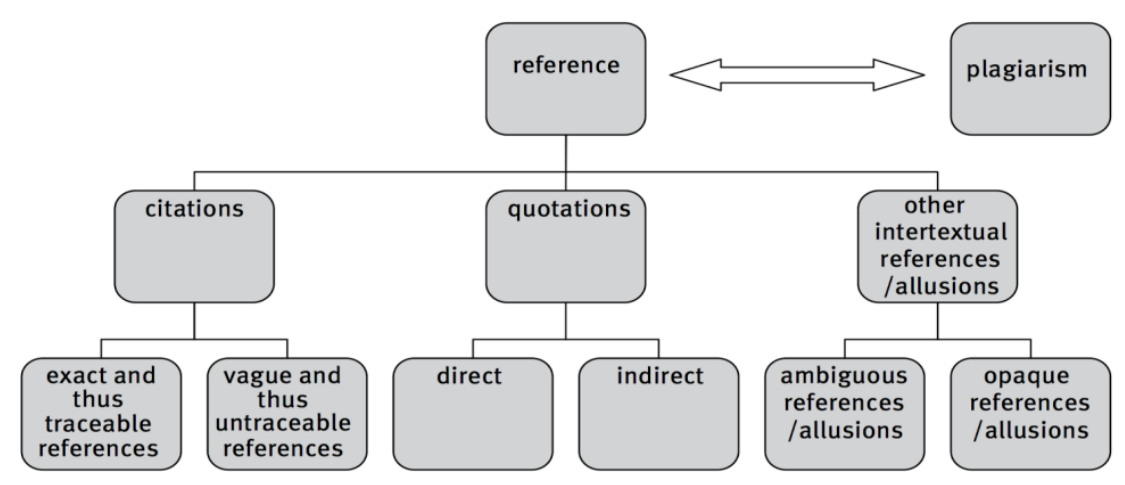

Figure 7: Kirner-Ludwig and Zimmerman's taxonomy of text reuse. ${ }^{198}$

${ }^{197}$ Potthast 2012: 1 stated, “Better known are things like quotations, translations, paraphrases, metaphrases, summaries, boilerplate text, and plagiarism, all of which can be grouped under the term 'text reuse' [...]. Reusing text is an integral part of writing in many genres so that the above kinds of reuse are widespread. The extent to which text is reused today, however, is still largely unknown, which is partly due to a lack of tools to study the phenomenon at scale."

${ }^{198}$ Kirner-Ludwig and Zimmermann 2015: 291-93. 
Originally, text reuse detection technology was developed from informatics (i.e., broadly, engineering for the practical purpose of identifying plagiarism, etc.) and intertextuality studies were developed in a wider sense from textual theory in the humanities for literary criticism. In recent years, as more investigations have been undertaken to detect text reuse in literary texts, text reuse and intertextuality have overlapped in the same fields and been combined in the emerging area of digital humanities. ${ }^{199}$

Research on the computational detection of text reuses (i.e., allusions, quotations, etc.) can be enriched by considering humanistic intertextuality analysis (i.e., how different authors and texts are related). Traditionally, studies on the use of technology to detect text reuse were conducted under the banner of text mining, an offshoot of data mining. ${ }^{200}$ Data mining refers to the use of technology to extract reusable information from unsorted raw data. In its early stages, it was primarily used to analyze numerical data through statistical methodology. "Knowledge discovery in database" (KDD) - another important term in computer science — and data mining are frequently used interchangeably. ${ }^{201}$

199 Berry 2012: 1-20.; also see Burdick et al. 2012: 121-36.

${ }^{200}$ For a more detailed history of data mining, see Fayyad et al. 1997. For current practical usages of data mining techniques, see Berry and Linoff 2004.

${ }^{201}$ Shi 2015: 2. In addition, for a more detailed definition of KDD from computer science, see Fayyad et al. 1996. 
Around 1990, which marked the beginning of the "information society," ${ }^{202}$ significant improvements in computer hardware and software enabled the development of text mining technology ${ }^{203}$ particularly in the area of natural language processing (NLP), which rapidly expanded. Although NLP is not text mining per se, text mining is dependent on NLP and cannot function without it. Text mining could be used to analyze textual data, while data mining could only be used to analyze numerical data. The costs of computer hardware steadily fell, and their capacity for storing data expanded. In the late 1990s, text mining grew rapidly, and research on the use of technology to detect text reuse expanded, initially to identify plagiarism in scientific papers. Companies began to offer plagiarism detection software; an early example was MOSS, which was created in 1994 by Alex Aiken. ${ }^{204}$

As previously noted, research on the detection of text reuse was an offshoot of research on text mining. ${ }^{205}$ The computational power required for this process was not available prior to the 1990 s. During the 1980s and earlier, it was only possible to analyze large quantities of data if it was in numerical form. From the 1990s onwards, the digital revolution enabled substantially larger quantities of data to

${ }^{202}$ See "A concise guide to developing regional information society initiatives" (http://ec.europa.eu/regional_policy/archive/innovation/pdf/risig/risig_en.pdf, last accessed on August 6, 2021). See also Karvalics 2007.

203 See Srivastava and Sahami (eds.) 2009.

${ }^{204}$ For a description and history of the software, see Aiken 2010-2018.

${ }^{205}$ See Aggarwal and Zhai 2012. 
be analyzed. This advanced the analysis of textual data, as far greater storage capacity is needed for the latter than for numerical data. Text mining technology can now be used to detect text reuse and analyze a textual corpus. The digital revolution gave rise to another aspect of text mining; developments in encoding technologies and universal encoding systems (e.g., Unicode) meant that technology could be applied to languages across a multitude of writing systems. Unicode, a universal encoding system, attempted to incorporate every character from every system of writing; it is now the standard encoding system and will be able to incorporate any future developments in writing. ${ }^{206}$

In the 21st century, data storage capacity has grown exponentially, and the Internet has become a global phenomenon. It is now the age of big data, which has had an enormous influence on text mining technology. With the highly improved processing power of computers, historical text mining has developed as an area of research. Unlike other areas of academia (e.g., medicine or physics), the humanities were traditionally regarded as the least appropriate academic field for the application of computer techniques. However, in 1949, the Jesuit Roberto Busa created the Index Thomisticus, ${ }^{207}$ a joint endeavor with IBM that digitized the works of Thomas Aquinas. ${ }^{208}$ Subsequently, journals and societies were formed to promote the use of digital technologies in the humanities. The first edition of the journal Computers and the Humanities was published in 1966. In 1973, the Association for Literary

${ }^{206}$ See Unicode Staff, CORPORATE 1991 and Graham 2000. Unicode is controlled by the Unicode Consortium (https://unicode.org, last accessed on August 6, 2021).

${ }^{207}$ See Burdick et al. 2012 and Busa 1951.
${ }^{208}$ For the collaboration of Busa and IBM, see Masoner 2018. 
and Linguistic Computing (ALLC) was founded, followed by the establishment of the Association for Computers and the Humanities (ACH) in 1978.

Simultaneously, technology that allowed researchers to analyze encoded texts exponentially improved. This led to the requirement of a unified standard to tag texts in digital humanities. To this end, the Text Encoding Initiative (TEI) was established during the mid-1980s. ${ }^{209}$ It created standard protocols using Extensible Markup Language (XML) technology ${ }^{210}$ and currently provides a standardized XML tag set. ${ }^{211}$ Most digital humanities projects use this tag set to mark up textual and para-textual information in transcriptions, texts, and documents.

${ }^{209}$ Text Encoding Initiative (http://www.tei-c.org/index.xml, last accessed on August 6, 2021).

${ }^{210}$ XML was sometimes regarded as an acronym for "eXtensive Markup Language" but has recently been spelled Extensive Markup Language. See the W3C consortium's description on XML at https://www.w3.org/XML, last accessed on November 2, 2021.

${ }^{211}$ The latest version of the tag set is written in P5 Guidelines (https://tei-c.org/guidelines/p5, last accessed on August 6, 2021). 


\subsubsection{Digital quotation biblical database for patristic}

\section{literature}

The hard copy version of Biblia Patristica, a publication series on biblical quotations and allusions in patristic literature, comprises seven books, ${ }^{212}$ with a supplementary volume on the works of Philo of Alexandria. The series spans the first, second, third, and fourth centuries. It is an important resource for the examination of text reuse in Late Antiquity, ${ }^{213}$ as it catalogs every biblical quotation found in the texts examined.

${ }^{212}$ Allenbach et al. (eds.) 1975, 1977, 1980, 1987, 1991, and 1995, and Pautler and Allenbach 2000.

Volume 1 contains extracanonical literature up to Clement of Alexandria and Tertullian. Volume 2 contains the third-century patristic texts, except Origen, whose work is featured in Volume 3. Volume 4 is dedicated to fourth century writers, including Epiphanius of Salamis, Cyril of Jerusalem, and Eusebius of Caesarea. Volume 5 covers the works of Gregory of Nyssa, Gregory of Nazianzus, Basil of Caesarea, and Amphilochius of Iconium. Volume 6 covers the Latin Fathers (e.g., Hilary of Poitiers, Ambrosiaster, and Ambrose of Milan). Finally, Volume 7 covers the work of Didymus the Blind.

${ }^{213}$ For intertextuality in patristic texts, see Osburn 2005; Mellerin and Houghton (eds.) 2013. Details of the biblical quotations in patristic texts referred to in Mellerin and Houghton (eds.) 2013 were published as the seven volumes of Allenbach (ed.) 1975, 1977, 1980, 1987, 1991, and 1995, Pauler and Allenbach (eds.) 2000, which has the intention of not simply being an electronic version of the data contained in its predecessor, cf. Mellerin 2013. 
Biblia Patristica went online on the BiblIndex platform in 2009. ${ }^{214}$ BiblIndex, an online database developed by the Sources Chrétiennes project, ${ }^{215}$ contains the entire electronic data of the quotations and allusions included in Biblia Patristica. BiblIndex has become the best-known database for examining patristic authors' reuse of biblical text. Currently, it only contains the works of Church Fathers from the third and fourth centuries, but it ultimately aims to cover the works of all Fathers and Mothers from Late Antiquity.

As seen on BiblIndex, earlier norms of acknowledging quotations do not meet the level of precision expected by the modern scholarship. Often, writers from Late Antiquity did not indicate the source of quotations. Even when they provided information about the quotations, it often lacked the author's name in cases where the source title was given or the source title in cases where the author's name was given. If page numbers were provided, they often differed from manuscript to manuscript, and the concepts of the publication and the publisher were different from what we have today. Thus, there is no easy path to identifying the exact source of the intertext. To address this issue, Biblia Patristica aims to identify the exact source of biblical intertexts in patristic literature. Moreover, the data of source information was described in the manner of the modern scholarly discipline of Patristics.

${ }^{214}$ For the website and its web database of BiblIndex, see http://www.biblindex.info, last accessed August 6, 2021.

${ }^{215}$ This institute is a member of HiSoMA (Histoire et Sources des Mondes Antiques), one of the CNRS (Centre National de la Recherche Scientifique) laboratories in Lyon II University. 
On BiblIndex, Biblia Patristica's data is tagged with TEI XML, which is widely considered the standard for textual mark-up in digital humanities. ${ }^{216}$ The database was intended to incorporate TRACER, but this has not yet been achieved.

\subsubsection{Detecting ancient Jewish quotations and allusions}

\section{with digital tools}

Early variant readings are occasionally preserved in allusions and quotations. By providing early evidence relating to the existence of their original text, this fact can help scholars improve their understanding of textual history and the different texts that were available in each book of the Bible. ${ }^{217}$ The University of Vienna Institute for Jewish Studies has conducted research in this area via a project called "The Meaning of Ancient Jewish Quotations and Allusions for the Textual History of the Hebrew Bible. ${ }^{218}$ Lange et al. examined allusions to and quotations from the Hebrew Bible in Second Temple literature by conducting manual searches for them. To this end, they employed the INFER command,

\footnotetext{
${ }^{216}$ Mellerin 2013:11.

${ }^{217}$ Lange and Weigold 2011.

${ }^{218}$ See Lange and Weigold 2011:15, 17.
} 
which only works in one language, in OakTree's Accordance software. ${ }^{219}$ Accordance contains all literature from the Second Temple period and digitized texts of several OT manuscripts.

Several computer programs can facilitate searches of the Bible and biblical literature, including Accordance, BibleWorks, and Logos Bible Software. Accordance and Logos Bible Software encompass the NT from J. Warren Wells' Sahidica and Bohairica, ${ }^{220}$ but their texts contain imperfect segmentation of words. Thus, it would be problematic to use quotation detection tools provided by Accordance and Logos Bible Software to search for allusions and quotations because thorough word segmentation is a pre-requisite for using these tools. According to the BibleWorks website, ${ }^{221}$ it is possible to add Sahidica to BibleWorks, but the same problem would remain.

\footnotetext{
${ }^{219}$ https://www.accordanceBible.com, last accessed on August 6, 2021.

${ }^{220}$ Sahidica is an edition of Wells's Sahidic translation of the NT; it is distributed in electronic and
} paperback formats. Bohairica is the Bohairic equivalent of Sahidica. Both are under their unique license, which allows users to reproduce these editions. As a result, several computer programs such as Logos Bible Software and Accordance, online corpus projects such as Coptic SCRIPTORIUM [see Subsection 3.1.4], and the STEP Bible by Tyndale House (https://www.stepbible.org, last accessed on October 27, 2021) make use of Sahidica.

${ }^{221}$ For more on the use of Sahidica in BibleWorks, see https://www.Bibleworks.com/forums/archive/index.php/t-2663.html, last accessed on August 6, 2021. For more on its use in Logos Bible Software, see https://www.logos.com/product/8024/sahidica-the-new-testamentaccording-to-the-sahidic-coptic-text, last accessed on November 2, 2021. For more on its use in Accordance, see https://accordancebible.com, last accessed on November 2, 2021. 


\subsection{Tesserae and TRACER}

Towards the end of the last decade, researchers in the field of digital humanities began to use programs to detect text reuse in original classical literature texts. The main programs used for this task were Tesserae and TRACER. Tesserae was launched in 2006 and was one of the earliest programs used to detect text reuses in Latin texts and not modern languages. Tesserae revealed many examples of intertexts that had previously been missed by scholars. For example, it identified 93 intertexts, out of which 46 were previously unknown text reuses, from Vergil's Aeneid in Lucan's Civil War. ${ }^{222}$

While Tesserae can only detect intertexts in Latin texts, TRACER can do so in multiple languages and across two or three languages concurrently (multi-lingual text reuse detection). It represents the cutting edge of technology that can be used to detect text reuse in historical texts. TRACER was created by the eTRAP research group. ${ }^{223}$ It can uncover a variety of text reuses including intertexts (i.e., text reuses from source texts), as Figure 4 illustrates. The latter demonstrate methods used in TRACER. For example, it divides text reuse into two categories, (i.e., syntactic and semantic),

${ }^{222}$ See Coffee et al., 2012: 401. In addition, Coffee et al. specified, "These works were chosen because they were long enough to give representative results, and well studied enough to allow comparison with traditional approaches. Each of our two tests was conducted with a different algorithm" (Coffee et al. 2012: 387).

${ }^{223}$ For details on this project, see Subsection 3.1.3. 
which makes it the most accurate program for identifying subtypes of text reuse. This is why TRACER was selected for the present research. ${ }^{224}$

The main advantage of employing text reuse software for intertextuality research is the fact that searches can be applied to any quantity of data. With a small corpus, a researcher who knows the Bible by heart may be able to effectively and swiftly identify examples of intertextuality. However, with a more substantial dataset that could be labeled as "big data" (e.g., the complete works of Besa, Shenoute, and, if we extend the scope, the rest of Coptic literature), even an expert may take several years to identify all instances of intertextuality. By using text reuse software, they could detect every example of intertextuality in a very short time period, perhaps in less than a day. ${ }^{225}$ Even then, the computational method has its merits, in that the corpus created for text reuse detection analysis can be reused as a searchable and easily browsable web corpus visualized for general users. To date, the field of Coptic research has yet to produce a collection of digital texts large enough to be considered big data. Nevertheless, projects such as Coptic SCRIPTORIUM and CoptOT have begun to produce more digitized Coptic texts, primarily digital editions, or transcriptions.

${ }^{224}$ For details on TRACER processing to detect text reuses between Psalms and Shenoute's Canon 6 and between Psalms and Besa's Letters and Sermons, see Subsection 3.2.2.

${ }^{225}$ Dependent upon processor performance. 


\subsection{History of intertext and text reuse}

\section{representation methods}

\subsubsection{Diplēs, italics, and quotation marks}

In a monograph titled Why Do We Quote? ${ }^{226}$ Ruth H. Finnegan examined historic uses of quotation marks and contended that they originated in the diplē. However, the diple seen in Coptic manuscripts is generally not reproduced in modern editions unless the editor provides an exact reproduction of the original manuscript, as in Munier's work in the Bulletin de l'Institut Français d'Archéologie Orientale ${ }^{227}$ Ancient authors sometimes drew attention to the fact that they were quoting

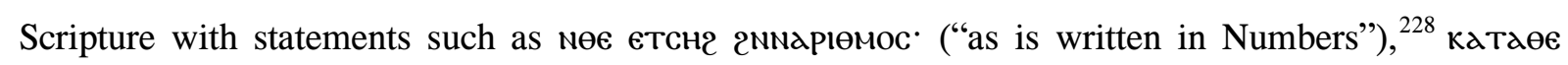
емтапапостолос хоOc ("according to what the Apostle said"), ${ }^{229}$ or simply nөє етснг ("as it is written"). ${ }^{230}$ However, they did not detail the quotation's precise location in the Bible. This is at least partly because the bibles of the time did not contain systems that enabled the precise location of any

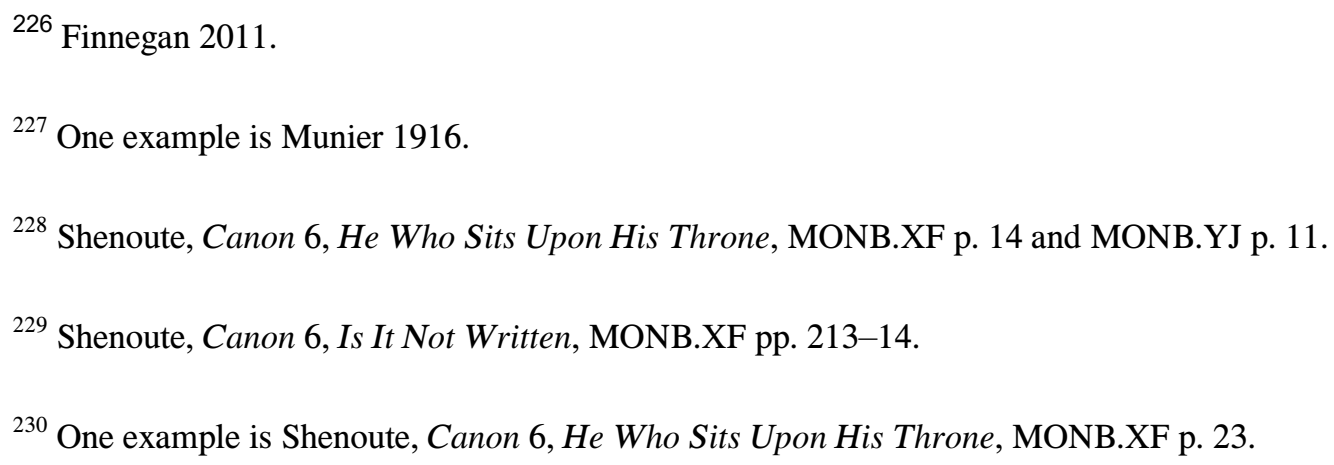


chapter and verse to be found; the now-familiar chapter or verse numbers were only added to European bibles between the 13th and 16th centuries.

In the ancient world, Greek, Latin, and Coptic texts use the diple to indicate the presence of a quotation. It is generally placed one on each side of a line that contains a quotation. The diple has been represented in several ways over time. According to Finnegan, the position and shape of the diple were highly dependent on the language used, the region in which the manuscript was produced, or even which individual scribe wrote the text. The diplē has been S-shaped, R-shaped, Y-shaped, V-shaped, cruciform, a single stroke, a double stroke, and more. ${ }^{231}$ The use of signs to indicate quotations clearly began with Greek writing; they either signposted a correction or important sections of the text. Keith Houston stated that this use of the diple began at the Library of Alexandria. ${ }^{232}$ This punctuation mark was inherited by Christian writers. One of the earliest examples of its use to indicate a quotation in a Christian text was in P. Oxyrhynchus 405. In this manuscript, Matthew 3:16-17 is quoted in Irenaeus's Against Heresies,

${ }^{231}$ Finnegan 2011: 88-89.

${ }^{232}$ Houston 2013: §6. Ptolemy II appointed Zenodotus of Ephesus, a grammarian, as its first librarian in the third century BCE. Zenodotus conducted revisions of the Homerian epics and created a sign called the obelus used for marking spurious lines. His successors — Eratosthenes, Aristophanes, and Aristarchus — invented several signs, including the diplē and diplē periestigmenē. Aristarchus used the diplè to highlight important elements of a text and the diplē periestigmen $\bar{e}$ (or dotted diplēe to mark passages in which his edition differed from Zenodotus's. Therefore, the original diple was used to highlight important sections of text, including quotations. 
and the quotation is indicated with diplēs. ${ }^{233}$ The diple is used to signal quotations in some of the first biblical codices (e.g., the Codex Alexandrianus and the Codex Sinaiticus). By contrast, quotations in the Codex Bezae are signaled through indented paragraphs.

Quotation marks in margins are commonly found in biblical publications, including Gregory the Great's Cura Pastoralis manuscript (sixth century CE), in which both OT and NT quotations are marked. ${ }^{234}$ During the seventh century CE, Isidore of Seville described the diplē, stating that Christian scribes used them in books for churchmen to indicate biblical citations. Thus, diplēs frequently appear in Latin, Greek, and Coptic manuscripts. Sometimes, the manuscripts of works by Shenoute and Besa contained diplēs to indicate quotations (e.g., Figure 8). Many Coptic manuscripts also featured this punctuation mark. For example, p. 49 of MONB.BA contains "Fragment 1: On Vigilance" 1:1-2:2, in which diplēs are clearly visible.

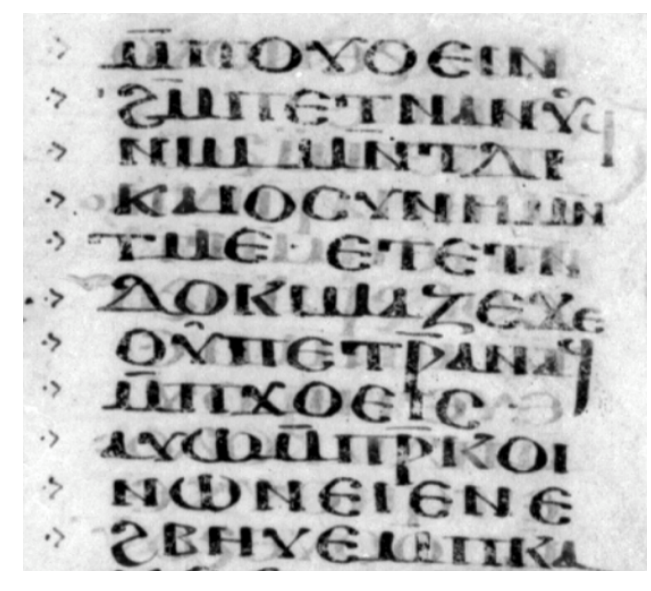

Figure 8: MONB.BA p. 49, col. 2, 1. 1-11 with diplēs shown to the left of each line.

\footnotetext{
${ }^{233}$ For a paleographical examination of the NT manuscripts, including instances of the diplēe, see
}

Comfort 2005: 25-26.

${ }^{234}$ Parks 1992: 170-71. 
Nevertheless, it is unclear what the diplēs in Figure 8 indicate. Although the lines marked with diplēs indeed contain quotations, other similarly marked lines do not.

As is sometimes the case today, a quotation could also be indicated by changing the formatting of the text (e.g., in the High Renaissance, italics frequently indicated quotations). ${ }^{235}$ After the Renaissance, the comma- and inverted comma-shaped quotation marks familiar to modern readers became a standard part of the writer's toolbox and became established as the standard quotation marks (although it should be noted that the original Gutenberg Bible and Tyndale's translation of the Bible do not use quotation marks). According to Finnegan, ${ }^{236}$ the first printed book to use quotation marks was De Vitis Sophistarum by Philostratos, which was printed in Strasbourg by Matthias Schürer in $1516 .^{237}$ In De Vitis Sophistarum, quotation marks are found in the left margin, similar to the diplē's position in Late Antique Christian manuscripts. In addition, the Olde and Newe Testament from Geneva (1560) features very early examples of the marginal side notes commonly found in modern Bibles, indicating intra-biblical quotations, as seen in Figure $9 .^{238}$

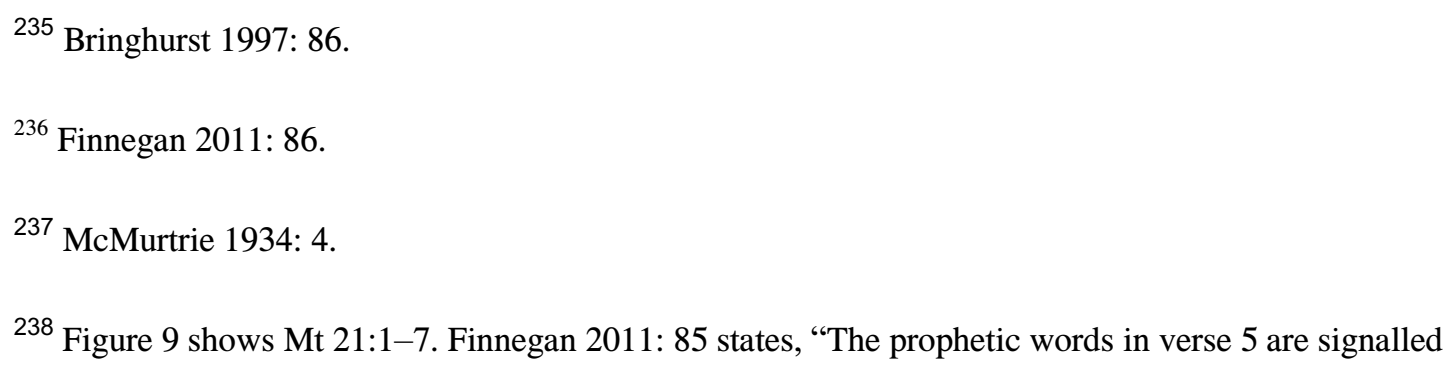
not by quotation marks but by a marginal reference to the earlier OT passages where they were first spoken (in Isaiah 62,11, Zachariah 9,9), and to a parallel passage in John's gospel 12,15 in the NT.” 


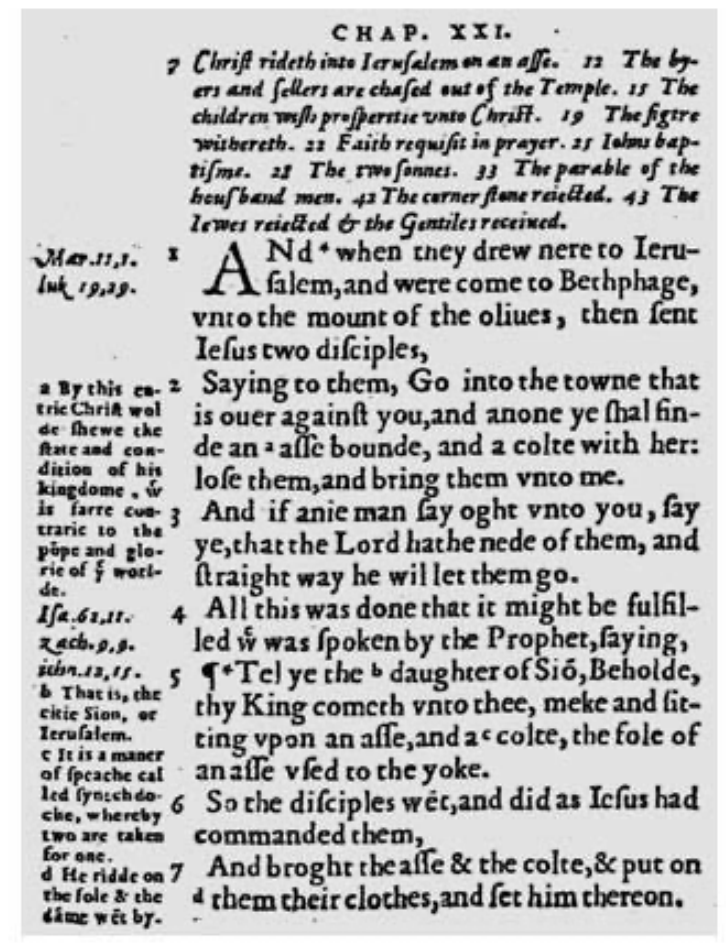

Figure 9: The Olde and Newe Testament (also known as the "Geneva Bible”), Geneva, 1560 (Finnegan

2011:85)

Gradually, quotation marks evolved from marginal use to indicating the beginning and end of a

quotation in the main text. Quotations could also be signaled through footnotes, side notes, indented

text, different fonts, and hyphens, all of which are still used in European publications today.

Not only the modern tradition in the Western churches, but also modern Coptic authors frequently use quotations - not in the same way as Late Antique authors but rather using modern biblical citation styles. Figure 10 is an example from an English translation of a treatise written by Pope Shenouda III. 
So God is fearful to the wicked. The righteous, however, are the friends of God who rejoice with Him. When Saint Antony the Great said to his disciples, "My sons, I do not fear God," they were amazed at this statement and answered, "Our father, these are difficult words." He then said to them, "This is because I love Him, and there is no fear in love, for "love casts out fear"” (I John 4.I 8). ${ }^{1}$

Imagine with me, my brothers, that God has now come into our midst. How many of us do you think will rejoice at His coming and embrace Him? And how many will be afraid, and try to escape? Sinners fear meeting God, and therefore they are afraid of death and tremble before it. They fear the great hour of judgment, when they will be exposed before everyone: in front of their enemies, who become malicious toward them, and in front of their friends, who thought that they were pure and righteous. When this hour comes, they shall "say to the mountains, 'Fall on us!' and to the hills, 'Cover us!' (Luke 23.30; Hosea ro.8). These people will seek death and will not find it; they will desire to die, and death will flee from them (Revelation 9.6).

Figure 10: An upper half of a page from Pope Shenouda III 2016: 76.

Thus far, this chapter has examined the ways in which quotations were indicated in Mediterranean and European writings from Greco-Roman Antiquity onwards. In addition, it has explored how quotation sources are usually signaled in the rapidly developing field of digital humanities - namely, within the framework of TEI XML. The following section explains how BiblIndex records quotations in XML. ${ }^{239}$

${ }^{239}$ Morlock et al. 2017. 


\subsubsection{Text reuse markup in the digital humanities}

Thesaurus Linguae Graecae (TLG) was founded in 1972 with the aim of digitizing all classical Greek literary texts, from Homer in the eight century BCE to the fall of Byzantium in 1453 CE. Between 1985 and 1992, TLG produced CD-ROMs containing ancient Greek texts that totaled 42 million words. ${ }^{240}$ The complete corpus has been available online since 2020 . On its website, TLG offers an Ngram intertextual phrase matching function that allows users to search for text reuses in Classical and Medieval Greek texts.

Before TLG released CD-ROMs, the Perseus Digital Library was established at Tufts University in 1985 by a team led by Gregory Crane and rapidly became a model for digital communities. ${ }^{241}$ It contains online corpora of Latin and Greek literature, with digital tagging, and includes works in other classical languages such as Arabic and Old Norse. All words in the Perseus corpus have been tagged using TEI XML. When a user clicks on a word, they are taken to a word form analysis page with a definition of the word, which comes from trusted lexicons (e.g., Liddell-ScottJones for Greek ${ }^{242}$ and Lewis and Short for Latin) ${ }^{243}$ and a detailed description of its morphology.

${ }^{240}$ See “The Thesaurus Linguae Graecae ${ }^{\circledR}$ : Our Mission and our Projects,"

http://stephanus.tlg.uci.edu/tlg.php, last accessed on August 6, 2021.

\footnotetext{
${ }^{241}$ See Smith et al. 2000.

${ }^{242}$ Liddell et al. 1996.

${ }^{243}$ Lewis and Short 1956.
} 
Together, TLG and the Perseus Digital Library became cornerstones of the digital humanities landscape in the area of literature from the classical period. The Perseus Digital Library provides quotation information through the simple "<quote>" TEI XML tag.

By contrast, as shown in Figure 11, the BiblIndex quotation marking methodology is extremely sophisticated, as the project exclusively focuses on text reuses from the Bible in patristic literature. Thus, it uses more elaborate and diverse ways to mark up text reuses than the Perseus Digital Library.

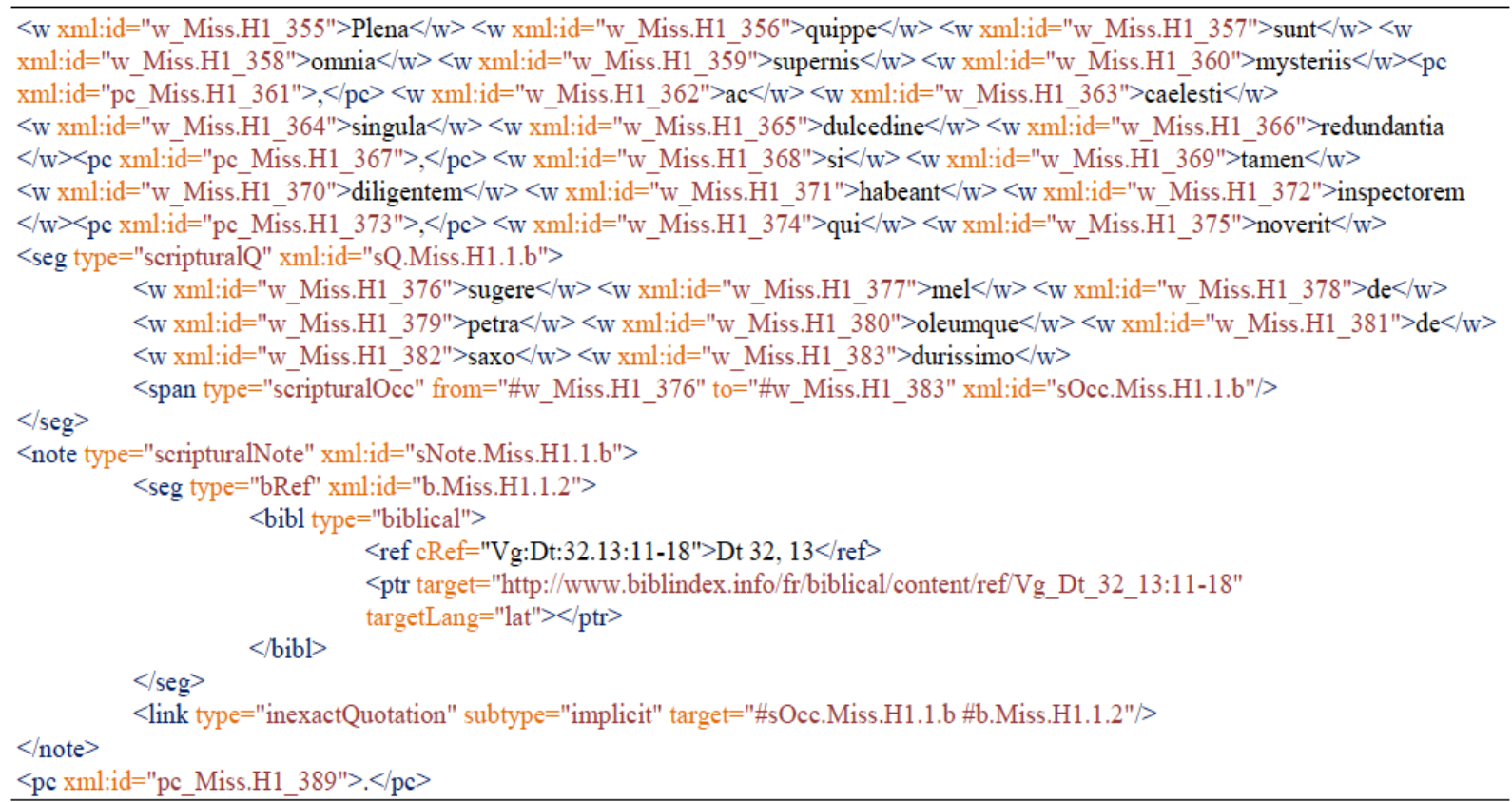

Figure 11: Quotations marked with XML tags in BiblIndex (taken from Hue-Gay et al. 2017: 13)

Figure 11 demonstrates how the BiblIndex team marks up biblical quotations. The quotation is bracketed by "<note>" and "</note>" tags. Figure 11 shows a biblical quotation from Dtn 13:11-18 cited by Bernard of Clairvaux in Homiliae in laudibus Viriginis matris I, 1. The markup for the quotation is as follows:

<note type="scriptura.Note" $\mathrm{xml}: \mathrm{id}=$ =" b.Miss.H1.1.2"> 


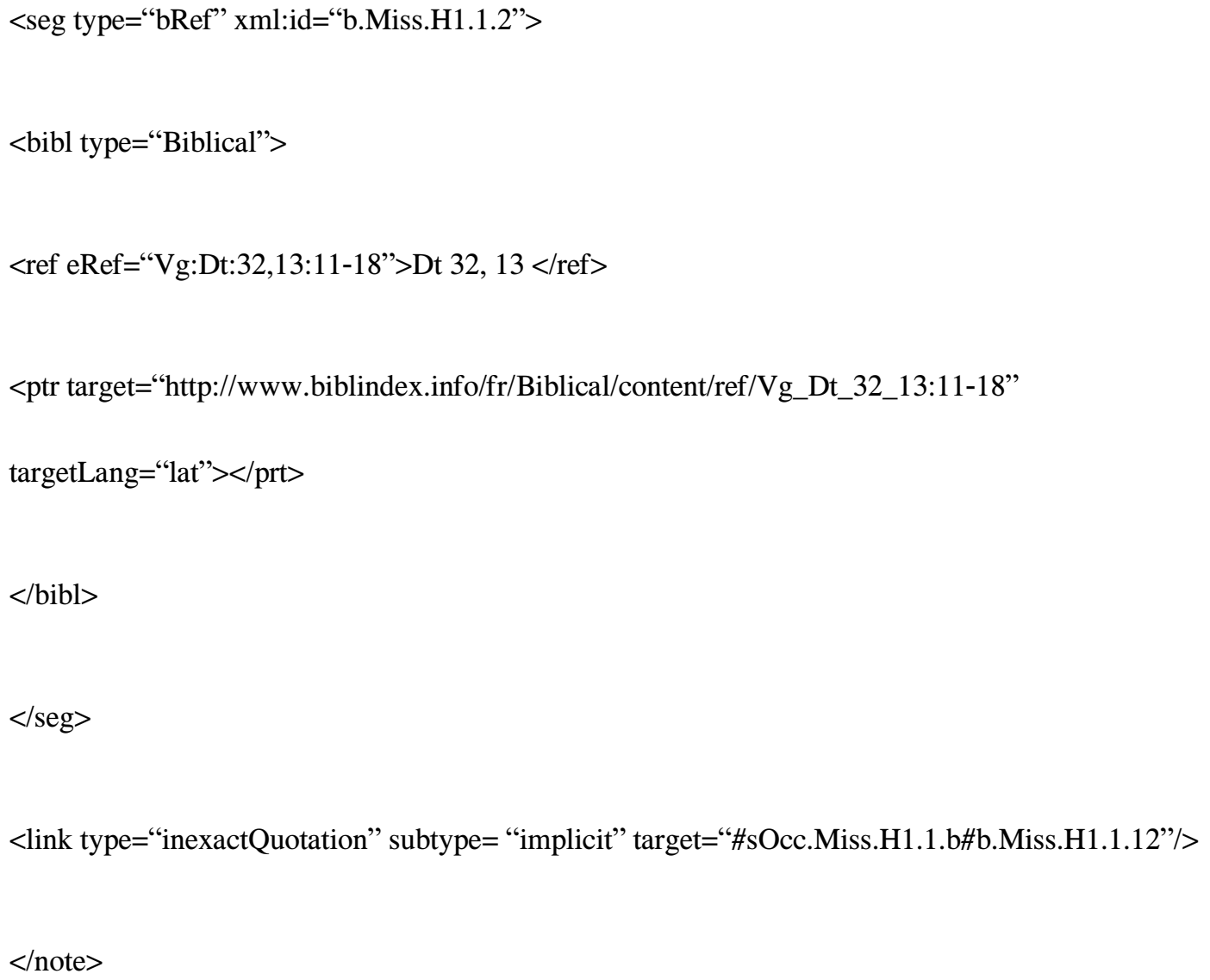

The text that represents the quotation is marked in eRef with the " $<$ ref $>$ " attribute as “eRef="Vg:Dt:32,13:11-18”>Dt 32, $13</$ ref $>$." The quotation type is also marked —in this case, with the "<bibl>" tag to indicate a biblical quotation. All intertextuality is indicated with the BiblIndex URL in the "@target” attribute in the "<ptr>" tag, such as "http://www.biblindex.info/fr/Biblical/ content/ref/Vg_Dt_32_13:11-18" in the example above. The quality of the quotation (e.g., how verbatim it is and any alterations it may contain) is indicated using the "<link $>$ " tag. In the above example, it is marked as "<link type="inexactQuotation" subtype="implicit" target="\#sOcc.Miss.H1. 1.b\#b.Miss.H1.1.12"/>." Quotations can be indicated in many more ways, such as by using the "<quote>" 
tag. This can be seen in following passage from the TEI Consortium, which exemplifies the use of the "<quote>" and "<ref $>$ " tags to tag quotations in TEI XML: ${ }^{244}$

Lexicography has shown little sign of being affected by the

work of followers of J.R. Firth, probably best summarized in his

slogan, <quote $>$ You shall know a word by the company it

keeps $</$ quote $>$

$<$ ref $>$ (Firth, 1957) $</$ ref $>$

In addition, the following example shows how the "<cit>," "<quote>," and "<bibl>" tags can be used to mark quotations in TEI XML: ${ }^{245}$

$<\mathrm{cit}>$

$<$ quote $>$ and the breath of the whale is frequently attended with such an insupportable smell, as to bring on disorder of the brain.</quote>

<bibl>Ulloa's South America</bibl>

$</$ cit $>$

${ }^{244}$ http://www.tei-c.org/release/doc/tei-p5-doc/de/html/ref-quote.html, last accessed August 6, 2021.

${ }^{245}$ http://www.tei-c.org/release/doc/tei-p5-doc/de/html/ref-cit.html, last accessed August 6, 2021. 
With XML, texts can be displayed with information about text reuses in margins, footnotes, pop-up windows, or bars at the bottom of the window. Another way to display information about text reuses is to convert the XML file into the HTML format by employing an XSLT converter. ${ }^{246}$ Additionally, a TEI XML environment facilitates the exchange of data between researchers and the reuse of data for different projects. ${ }^{247}$

\subsection{Intertextuality studies in Coptic literature}

This section reviews the marking of biblical text reuse in Coptological text editions and related publications. The works of Alastair Hamilton ${ }^{248}$ and Stephen Emmel $^{249}$ provide useful background information about the history of Coptic studies in early modern Europe. Hamilton's work explores the entirety of this history from 1439 to $1822 \mathrm{CE}$, while Emmel examines the history of Coptic research prior to Athanasius Kircher through scholars such as Joseph-Juste Scaliger (1540-1609) of Leiden

\footnotetext{
${ }^{246}$ XSLT stands for eXtensible Stylesheet Language Transformations.

${ }^{247}$ See Morlock 2014.

${ }^{248}$ Hamilton 2006.

${ }^{249}$ Emmel 2004a.
} 
University and his book Opus de Emendation Temporum. ${ }^{250}$ Although Scaliger's book was published on printing presses, they did not incorporate printed Coptic texts. ${ }^{251}$

It could be argued that Athanasius Kircher (1602-1680) was the first individual to use the new printing technology to publish Coptic texts using Coptic script and Coptic typesetting. Kircher was an early researcher of the Coptic legacy and is still remembered and respected for his grammar of the Coptic language. Although he did not live in the Renaissance, he was in many ways a Renaissance man, producing works on astrology, geology, physics, musicology, biology, sinology, and more. Kircher had the advantage of receiving enormous quantities of information in the form of reports by other Jesuits from every part of the world, which certainly helped his work.

Kircher's Prodromus Coptus sive Aegyptiacus ${ }^{252}$ was the first comprehensive Coptic grammar to be published in the West. While the book uses many examples to demonstrate how the Coptic language is structured, Kircher did not note their sources. After the publication of Prodromus Coptus sive Aegyptiacus, he turned his attention to other areas. Although he sometimes returned to Egyptian, it

\footnotetext{
${ }^{250}$ Scalinger 1598.
}

${ }^{251}$ Scaliger lived most of his life in the 16th century, when the Protestant Reformation was driven by crusaders such as Martin Luther, John Calvin, and Huldrych Zwingli, and movable type enabled the rapid and economical printing of books. Although modern movable type printing was invented in Europe by Johannes Gutenberg in the 15 th century, it only became commonplace in the 16 th century.

${ }^{252}$ Kircher 1636. 
was not to study Coptic texts: his later interests involved Pharaonic Egypt and deciphering the hieroglyphs.

After Kircher, a more academic Coptic grammar was produced by Guillaume Bonjour (16701714). ${ }^{253}$ If we turn from Coptic texts used as examples in grammars to full printed edition, we find a pioneer in Rafael Al-Tukhi (1701-1787), a significant early Copticist who converted to Catholicism from a non-Chalcedonian faith. ${ }^{254} \mathrm{He}$ produced Bohairic Coptic texts that were primarily employed in the liturgy (e.g., Psalms and Euchologion) using Coptic type with the new printing technology. However, they did not usually contain indications on text reuse even though part of their content was copied from the Bible or certain elements of the Psalms matched other books from the OT. The omission of any notations on intertext is a practice that persists in modern Coptic liturgical texts.

Al-Tukhi taught Coptic at an Egyptian catholic seminary and produced a textbook called Rudimenta Linguae Coptae sive Aegyptiacae $e^{255}$ aimed at those who wished to learn the language. It contains many quotations, especially from the Bible. Unlike Kircher's work, the book provides detailed acknowledgements of source material. However, the quoted parts were used to demonstrate the structure of Coptic or to help students practice the language.

\footnotetext{
${ }^{253}$ Bonjour 1698. See Bosson and Aufrère 2015 and Takla 2014: 188-89.

${ }^{254}$ See the article on Rafael Al-Tukhi written by Rushdi Al-Tukhi in the Coptic Encyclopedia (Al-
} Tukhi 1991).

\footnotetext{
${ }^{255}$ Tuki 1778.
} 
Jørgen (Georgius) Zoëga (1755-1809) was a Danish scholar who studied ancient cultures with Christian Gottlob Heyne at the University of Göttingen. In 1783, he journeyed to Rome and, under the patronage of Cardinal Borgia, researched the Coptic manuscripts that were available in the city. ${ }^{256}$ This led to the production of Catalogus Codicum Copticorum Manuscriptorum qui in Museo Borgiano Velitris Adservantur ${ }^{257}$ in 1810. It was more than an inventory, containing many transcriptions of the manuscripts held in the Borgia Collection, which included works by Shenoute. However, these transcriptions do not incorporate any references to allusions or quotations. While Copticists in the 16th, 17th, and 18th centuries did not appear to habitually mark quotations or allusions in any text that they studied or produced, this would change in the 19th century.

During the latter half of the 19th century, Dutch Egyptologist Willem Pleyte (1836-1903) and a younger colleague, Pieter Adriaan Aart Boeser (1858-1935), published several Coptic texts. Their book, Manuscrits Coptes du Musée d'Antiquités des Pays-Bas à Leide (1897), ${ }^{258}$ was an edition of Coptic manuscripts and incorporated notes on text reuse, particularly quotations. It is now preserved at

${ }^{256}$ One of the largest convolutes (more than 2,300 pages and fragments) from the White Monastery library was acquired by Borgia in 1778. Zoega's cataloguing of Coptic manuscripts in this collection represents a masterpiece of early cataloguing work. After Borgia's death, the manuscripts were divided between the Biblioteca Vaticana (biblical manuscripts) and the Biblioteca Nazionale in Naples (literary manuscripts: Buzi 2009). In addition, see Buzi 2015.

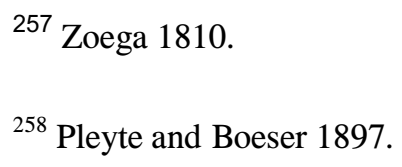


Rijksmuseum van Oudheden in Leiden. Most text reuses in this edition were biblical quotations, but the version or translation of the Bible used was not indicated. There was only the most basic information given about a quotation, simply comprising the abbreviated name of the biblical book, chapter, and verse. In this book, Pleyte and Boeser published Shenoutean texts, including some from Canon 6, held by Dutch institutions.

Émile Amélineau (1850-1915), a contemporary of Boeser, published several Coptic texts, including an edition of Shenoutean manuscripts from the Bibliothèque Nationale de France, a monumental work that remains in use today despite containing errors. Although Amélineau provided footnotes on intertexts and text reuses, he seemingly investigated quotations using the Vulgate and the Septuagint. ${ }^{259}$ In his edition, the pages are divided into three sections: Coptic transcriptions, French translations, and footnotes. It is the French translations that contain the footnotes. There were frequent errors in transcriptions, and text reuse was often incorrectly identified, as noted by Emmel. A key feature of Amélineau's work was that he distinguished between allusions and quotations in the footnotes; allusions were frequently marked as "Cf."

At the beginning of the 20th century, a subseries called "Scriptores Coptici" was added to the series "Corpus Scriptorum Christianorum Orientalium" dedicated to the literature of the Christian Near East. The initial publication in this collection was Leipoldt's Sinuthii Archimandritae Vita et Opera

\footnotetext{
${ }^{259}$ For examples, he cited both the Vulgate and the Septuagint; see Amélineau 1907: 280: fn. 11, 283:
} fn. 6, 351: fn. 14 . 
Omnia, I. Sinuthii Vita Bohairice ${ }^{260}$ which was created with the assistance of Walter Ewing Crum. Subsequently, Leipoldt and Crum edited Sinuthii Archimandritae Vita et Opera Omnia, III ${ }^{261}$ and Sinuthii Archimandritae Vita et Opera Omnia, $I V{ }^{262}$ They contained an apparatus with the readings in parallel manuscripts, but no marking of text reuse. However, this information was provided by Hermann Wiesmann, who published Latin translations of Sinuthii Archimandritae Vita et Opera Omnia, III and Sinuthii Archimandritae Vita et Opera Omnia, IV in 1931 and 1936 respectively. ${ }^{263}$ Wiesmann's footnotes contained more identifications of text reuse than those of either Amélineau ${ }^{264}$ or Pleyte and Boeser. ${ }^{265}$ Based on the versification, he undoubtedly used a version of the Septuagint.

In contrast to Pleyte and Boeser (1897), Amélineau (1907 and 1911) and Wiesmann (1931 and 1936) noted information about intertexts in Shenoute's works in the modern translations of the texts rather than in the editions of the original Coptic, which remains the standard scholarly practice. The same applies to most recent publications (e.g., Anne Boud'hors' edition of MONB.XO, a codex including Canon $\left.8^{266}\right)$.

\footnotetext{
${ }^{260}$ Leipoldt and Crum 1906.

${ }^{261}$ Leipoldt and Crum 1908.

${ }^{262}$ Leipoldt and Crum 1913.

${ }^{263}$ Wiesmann 1931 and 1936.

${ }^{264}$ Amélineau 1907 and 1914.

${ }^{265}$ Pleyte and Boeser 1897.

${ }^{266}$ See Section 4.2.
} 
As a result, previous editions of Shenoute's works — specifically, those that cover large parts of Canon 6 - either do not identify text reuses at all (e.g., Wessely ${ }^{267}$ and Munier ${ }^{268}$ ) or include some indication of text reuses but contain errors (e.g., Amélineau ${ }^{269}$ ). Moreover, editions that note text reuses in detail only cover small sections of Shenoute's works (e.g., Wiesmann ${ }^{270}$ ). For researchers who did not know the Bible, primary strategies for identifying quotations previously included searching for linguistic features and using quotation alert formulae, which are reviewed in more detail in Section 2.6.

\subsection{Linguistic features of text reuses in Shenoute's}

\section{works}

\subsection{1. $\quad$ Linguistic studies}

The identification of biblical text reuses plays an essential role in Coptic linguistics. Thus, it is vital that methods should be developed for identifying them in Shenoute's works, which constitute the

\footnotetext{
${ }^{267}$ Wessely 1909, 1911, 1912, 1914, and 1917.

${ }^{268}$ Munier 1916.

${ }^{269}$ Amélineau 1907 and 1914.

${ }^{270}$ Wiesmann 1931 and 1936.
} 
preeminent corpus of Coptic original literature. As Shisha-Halevy stated, Shenoute's writings are viewed as outstanding among Coptic literary sources because their corpus "constitutes the single most extensive homogenous and authentic testo di lingua for Sahidic and Coptic in general."271

Accordingly, linguists must separate text reuses and Shenoute's own words to ensure they are only studying his original language. As Behlmer (among others) showed, there is a plethora of biblical quotations in Shenoute's corpus, ${ }^{272}$ which Shisha-Halevy described as "the SUB-CORPUS OF QUOTATIONS, mainly Biblical, interwoven in the text." ${ }^{, 273}$ This sub-corpus of biblical quotations causes problems for the linguistic study of idioms used by Shenoute. Until now, it was impossible to state with certainty which parts of the text came from the L1 source, ${ }^{274}$ which is extremely valued by linguists, and which represented a Greek-to-Coptic biblical translation. Any researcher who engages in a linguistic study of Shenoute's works must be able to distinguish between biblical quotations and the native speaker's original composition.

${ }^{271}$ See Shisha-Halevy 1992: 202-04. Also, Schroeder 2006: 81 states, “The writings of the fourth and fifth century Egyptian monastic leader Shenoute of Atripe have often been cited as unparalleled resources for the study of the Coptic language [...]."

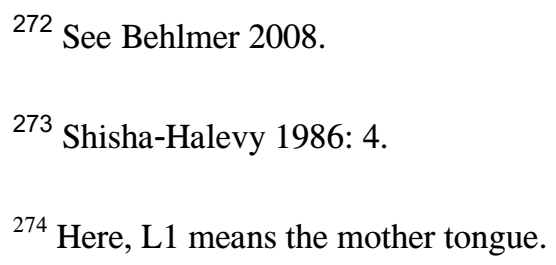


Shisha-Halevy described the syntax of Shenoute's Coptic idiolect ${ }^{275}$ as that of an L1 speaker ${ }^{276}$ whose writing is littered with biblical quotations and reminiscences, which he only identified if necessary for his linguistic study. ${ }^{277}$ Shisha-Halevy provided examples of the characteristics of quotation and non-quotation in Shenoute's works, describing in detail some of the distinguishing features of quotations and his own style of writing. Nevertheless, as he stated, it is difficult to distinguish between the two unless quotations are indicated by чснг $\chi_{\epsilon-}$ "it is written," мөє єтснг $\chi_{\epsilon-}$ "as is written,"

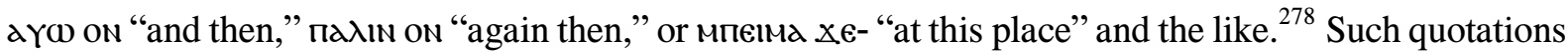
provide "a glimpse into an extraneous system of grammar." 279 Shisha-Halevy provided the example of

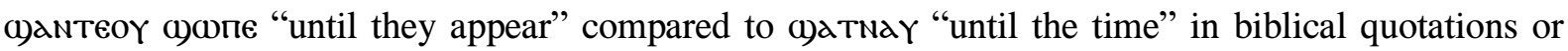
тарєчсотм "and he will hear" with Shenoute's paradigm of post-imperatival forms. In addition, he stated, "Shenoute's own awareness of this contrast of norms is evident, since he puts it to rhetorical use, switching now and again to the Scripture diasystem, ringing diaphasic changes, achieving archaic, pathos-carrying, authoritative effects." 280

\footnotetext{
${ }^{275}$ See Shisha-Halevy 2016a: 1333 and Shisha-Halevy 1986: 9.

${ }^{276}$ See fn. 274

${ }^{277}$ Shisha-Halevy 1986: 53.

${ }^{278}$ Shisha-Halevy 1986: 4.

${ }^{279}$ Shisha-Halevy 1986: 4.

${ }^{280}$ Shisha-Halevy 1986: 53.
} 
Shisha-Halevy undertook a thorough investigation of maגıN $(\lambda \epsilon)$ on, which is "a premodifier, introducing (often in a series of predications, quotations or in reporting) an additional predication." With

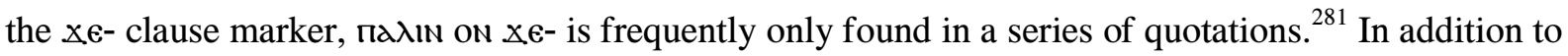
"חג入In on," Shisha-Halevy mentioned that the Second Tense, which is often used to quote a discredited subjective claim, thought, or statement, can be another indicator of a quotation. ${ }^{282}$

According to Shisha-Halevy, the most significant way to grammatically distinguish between quotations and non-quotations is the difference between the first-person singular Conjunctive $T d-$ or NTd- ${ }^{283} \mathrm{He}$ noted, "Indeed, Tapєฯ- is an unmistakable sign of a biblical quotation or reminiscence in

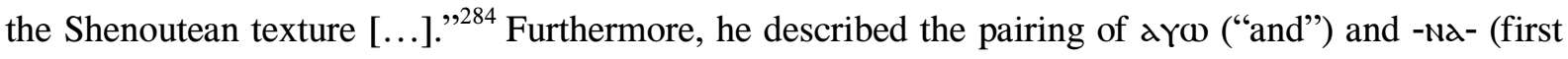
future) as a biblical style and an indication of quotation use. ${ }^{285}$ The following list summarizes ShishaHalevy's findings on quotation indicators:

${ }^{281}$ Shisha-Halevy 1986: 58 mentioned that חג入IN $(\lambda \epsilon)$ on [(and/but) again, "but then," and "alternatively"] can introduce an additional predication in a series of quotations as well as in a series of predications or reporting.

${ }^{282}$ Shisha-Halevy 1986: 77: "The Second Tense used in quoting or attributing a subjective claim, thought or statement that is thereby more or less strongly discredited ('... so they say' would approximately convey this meaning); Second Present (very rarely, Sec. Perfect); all persons; affirmative only?”

283 "Variation status for NTd-/Td- in Shenoute immediately identifies the non-Shenoutean grammatical system of quotation [...]." (Shisha-Halevy 1986:187).

${ }^{284}$ Shisha-Halevy 1986: 195.

${ }^{285}$ See Shisha-Halevy 1986: 198 for examples. 


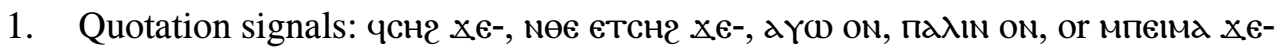

2. Combination of a $\gamma^{0}$ and Future I

3. Conjunctive Td- or $\overline{\mathrm{N} T d}-$

4. Future Conjunctive Tapeq-

Shisha-Halevy also attempted to categorize the ways in which Shenoute reused biblical texts. He established two main criteria: ${ }^{286}$ how authentically the texts are and the level of biblical intertexts that they contained. For the first criterion, Shisha-Halevy suggested a strategy to evaluate "Shenoutianity" through the assessment of idioms, style, grammar, and lexicon. ${ }^{287}$ The second criterion was more challenging to address, given that the texts hold "the countless phraseological, lexical-idiomatic and even grammatical segments of the Scripture language" ${ }^{288}$ and that Shenoute's use of quotations was "more or less faithful to the received Scripture text but in great detail, to Scriptural episodes." ${ }^{289}$ The aforementioned elements (i.e., quotation signals, a $(\omega)+$ Future I, Td-/NTd-, and Tapeq-) should be of assistance to distinguish Scriptural quotations in Shenoute.

\footnotetext{
${ }^{286}$ Shisha-Halevy 1976: 55.

${ }^{287}$ Shisha-Halevy 1976: 54: "The question of the authentic and provable Shenoutianity of a given text
}

(where the author is not named or otherwise immediately identifiable) [...] has, I think, a linguistic solution, almost totally reliable, and none other."

${ }^{288}$ Shisha-Halevy 1976: 55.

${ }^{289}$ Shisha-Halevy 1976: 55. 
According to Shisha-Halevy's arguments, it is possible to separate quotations from direct writing through linguistic signs that are typically found in biblical quotations. Nevertheless, solely relying on such criteria to identify the biblical text reuses is problematic. Firstly, these linguistic measures can only be relied on to examine verbatim quotations, not paraphrases, allusions, or significantly adapted quotations. Secondly, there are only a small number of grammatical indicators that are typical for the Sahidic Bible, but even these do not appear consistently. Thus, it is impossible to fully rely on grammatical indicators.

Instead, other search strategies must be used to identify biblical text reuses. It is possible to conduct keyword searches in available Coptic biblical works, but this was an arduous process without digital transcriptions of the texts. Such pursuits were rare until the Packard Humanities Institute created digital transcriptions of the Sahidic Scriptures in 1991, which were either taken directly from the manuscripts or extant editions. An earlier edition of the Sahidic NT edited by David Brakke was available, but it was less accessible. ${ }^{290}$ Subsequently, the Saint Shenouda the Archimandrite Coptic Society produced a digitized version of the NT in 1998; the most recent edition was released in 2007 .

${ }^{290}$ On the history of this version of the Coptic NT, the website of the STEP Bible — an online Bible study application developed and duplicated by the Tyndale House — states, "Sahidica was initially based (by permission) on the Coptic NT, which is an electronic publication, which was edited by David Brakke.” (https://www.stepBible.org/version.jsp?version=CopSahidica, last accessed on August 6, 2021). The electronic publication edited by Brakke was distributed as a CD published by the Packard Humanities Institute, Los Altos, in 1991. 
In addition, J. Warren Wells used the Packard Humanities Institute version of the Coptic NT to work on Sahidica from 2000 to 2008 . The books of the Sahidic OT were only made available as digital transcriptions after the NT had been digitized. To the best of the author's knowledge, the version of the INTF created by Christian Askeland and Matthias Schulz represents the first digital publication that includes a substantial proportion of the OT books. ${ }^{291}$

\subsubsection{Quotative index phrases}

The primary categories in intertextuality are quotations and allusions. Before the modern era, it was not general practice to precisely identify their source. Early Christian authors occasionally used idiomatic phrases or subordinate clauses to indicate a source (e.g., "as X wrote" or "as it is written"). Dietrich-Alex Koch $^{292}$ separated quotations into two types: those that have an introduction and those that do not. The introduction most frequently used in Greco-Roman Antiquity and Late Antiquity was "as it is written." Often (but not always), Shenoute prefaced quotations from Scripture with this phrase (or a variation of it): Nөє етсн2 ("as it is written").

${ }^{291}$ The version called Sahidic Bible 2.0 is available on the CrossWire Bible Society's website. See https://www.crosswire.org/study/fulllibrary.jsp?show=SahidicBible, last accessed on October 31, 2021. It includes the entire base text of CoptOT and will be updated as the project progresses. For more technical details on this version, see Subsection 3.1.4.

${ }^{292}$ Koch 1986: 11-12. 
There was no specific way to introduce a quotation during Late Antique Egypt, except for verbal introductions and the diple ${ }^{293}$ In the modern era, a quotation is usually signaled by an introductory or post-positioned phrase, such as "X put forward the argument that" or "as X suggests," and the quotation is bracketed by some form of quotation mark [e.g., single or double quotation marks in English or German, pointing double angle quotation marks («») in French, or corner brackets $(\ulcorner 」)$ in Chinese, Japanese, and Korean]. However, these marks were not generally used to indicate quotations in GrecoRoman Antiquity and Late Antiquity. Except for a small number of cases using diplēe, verbal signals were used to indicate intertexts. Rönnegård called such a verbal signal "an indicator of quotation, paraphrase or allusion." ${ }^{294}$ In addition, in Coptic Studies, Janet Timbie and Heike Behlmer referred to them as "signals"295 and (Zitat)Einleitung, respectively.

In this dissertation, these expressions are subsumed under the term "quotative index phrase" (QIP) which indicates all types of introductions to a quotation. ${ }^{296}$ "Quotative index phrase" alludes to the term "quotative index," which is used in linguistics to indicate a verb phrase with a complementary introduction, such as "I said." The quotative index generally shows the main clause in a sentence by prefixing it with a quotative clause (e.g., "I said, 'I am leaving."”). The term "quotative index" originated

\footnotetext{
${ }^{293}$ For a history of the diple, see Subsection 2.4.1.

${ }^{294}$ Rönnegård 2010: 26.

295 Timbie 2007: 629.

${ }^{296}$ For a more detailed discussion of QIP, see Miyagawa and Behlmer (forthcoming a and b).
} 
in the works of Tom Güldemann, ${ }^{297}$ an expert on African languages. The next paragraph discusses how QIPs are used in Shenoute's works and why he used it for specific quotations and not others. This is highly pertinent for examining his rhetoric style. Such phrases were frequently used in ancient Christian writing, such as in the letters of Paul. The study of QIPs may also provide insight in why Shenoute sometimes used QIPs and other times not.

Shenoute's monasteries followed an adapted version of the Pachomian Rules. Thus, monks and nuns in the White Monastery Federation would have been compelled to commit biblical passages to memory, particularly Psalms. ${ }^{298}$ Timbie demonstrated that the rules of both the White Monastery Federation and the Pachomian Federation echoed rules expressed in the Pentateuch. ${ }^{299}$ If monks and nuns were obliged to continuously read the Bible and to commit sections to memory, as established in the Pachomian system, monks and nuns would have been highly familiar with numerous quotations used by Shenoute. Therefore, they may not have felt the need to specifically identify them using QIPs. Nevertheless, Shenoute used quotations from different parts of the Bible, some of which may not have been common in daily use or in the liturgy. It can be hypothesized that, when he used a QIP, it was because he was referring to a lesser-known quotation that his audience may not have immediately

\footnotetext{
${ }^{297}$ Güldemann 2008.

${ }^{298}$ Rules 139 and 140; Boon 1932: 49-50. For the English translation, see Timbie 2016: 35.

299 Timbie 2011.
} 
recognized. However, this hypothesis does not hold up under scrutiny, as Shenoute frequently employed QIPs when quoting from the Psalms, texts that his audience would have been extremely familiar with. ${ }^{300}$

Shenoute not only used QIPs for biblical quotations but also for other types of quotations, even - as in one example - non-Christian source texts. The QIP in question is "as it is written in your books," which can be seen in the following passage that refers to the worship of Kronos-Petbe: ${ }^{301}$

Where is Kronos, namely Petbe? He is the one who waylaid his parents, while they were with one another. He cut off the private parts of his father with a sickle, according to what is written in your

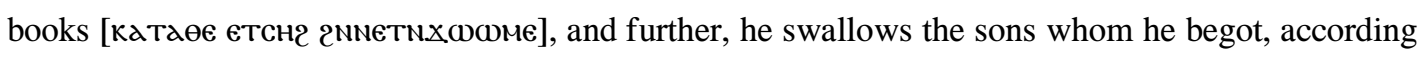
to your fables. ${ }^{302}$

The phrase "your books" may refer to Hesiod or another specific but unnamed work of pagan literature, or to pagan writings or mythology in general ("your fables"; Coptic: мєTn()ахє N()B()). A specific source text cannot be extrapolated. The addition "your books" makes it clear that, although Shenoute used a QIP, he did not consider the books in question to be authoritative. Instead, he "others" them, establishing a hierarchy between an inside and an outside group. Thus, this example is quite different from Shenoute quoting from authoritative Christian texts.

\footnotetext{
${ }^{300}$ Miyagawa and Behlmer (forthcoming a and b).

${ }^{301}$ This point is further discussed in Miyagawa and Behlmer (forthcoming a).

${ }^{302}$ The Lord Thundered, Discourses 4, Work 1 (MONB.DU, pp. 55-56): Amélineau 1907: 383-84,
} translated by Timbie and Zaborowski 2006: 116. The Coptic QIP (in square brackets) was added to Timbie and Zaborowski's translation by the present author. 


\subsubsection{Quotation signals in Shenoute's works}

Timbie analyzed the ways how Shenoute signaled quotations. ${ }^{303}$ According to Timbie,

[t]he signaling formula may be based on a phrase with « as it is written » (based on cнг), on a reference to « the scriptures » (меграфн) or « words » ( ()גхє), or on the simple « as it is said » (based on $х \omega$ $\bar{M}$ MOc). The quote, either exact or slightly adapted, may precede, follow, or bracket the signaling formula. ${ }^{304}$

When these signaling formulae are combined with references to a particular name or pronoun, such as "wisdom," "the apostle," or "the prophet," Timbie claimed that "specific text of Scripture is being cited, though it may be modified in tense or number to fit the discourse."305

Timbie proposed that the reason why Shenoute used these formulae to signal specific quotations and not others is that "anonymous scriptural citations generally have introductory or signaling formulae

\footnotetext{
303 Timbie 2007.

304 Timbie 2007: 629.

305 Timbie 2007: 629.
} 
that are flags warning the reader to dig deeper and identify the specific text that Shenoute has in mind."306 The following list represents Timbie's taxonomy, with examples to accompany her translations: ${ }^{307}$

1. Using снг, as in "as it is written/it is written":

a. From I Am Amazed: "For it is written (чсн2), 'The Lord will not do a thing that he did not reveal to his servants, the prophets' (Amos 3:7).” The formula precedes the quotation.

b. From The Lord Thundered: "'This is your portion and this is your lot' (Wis 2:9), as it is written

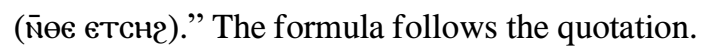

c. From I Am Amazed: “'An abomination to the Lord is the sacrifice of the impious', as it is written (катдөє єтсн2), 'for they are offered up unjustly' (Prov 21:27)." The formula is enclosed by the quotation.

2. Using меграфн, as in "according to the Scriptures":

a. From The Lord Thundered: "'The sun will turn to darkness and the moon to blood' (Joel 2:31), according to the Scriptures (катд меграфн), and further, 'the stars will fall from heaven like grape leaves' (Is 34:4).” The formula is enclosed by quotations from the Scripture.

3. Using $\chi \omega \bar{M} M O C$ as in "as it is said":

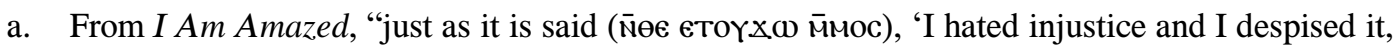
but your law I loved' (Ps 118:163 [119:163]); and also. 'I hated every unjust way' (Ps 118:104 [119:104]); just as also it is prayed (єтоү()גн入), 'Let no lawlessness rule over me' (Ps 118:133

${ }^{306}$ Timbie 2007: 629.

${ }^{307}$ Timbie 2007: 629-30. The accompanying translations were produced by Timbie. This taxonomy itself was developed by her from Shisha-Halevy's analysis on Shenoute's quotation signaling phrases (ShishaHalevy 1975: 55). 
[119:133])." Adjacent quotations from Psalms are linked and follow the formula.

b. From De Indicio: "As it was said (ката пемтаYхоoч), 'this (one) who will change the body of our humility to the image of his glory' (Phil 3:21)"

4. Using Neic)dxe as in "these words":

a. From Righteous Art Thou: "For we care not for these words, namely, 'You shall not do an unjust act in judgments, in ephah, in measures, in balances' (Lev 19:35)"

In some cases, lengthy biblical quotations lacked any signaling formulae. In other cases, $x e^{-}$ was used to indicate the quotation that preceded it: ${ }^{308}$

b. From The Lord Thundered: "But as for the Christians, 'it is a single God who exists for them, the Father, and a single Lord, Jesus the Christ"”

c. From The Lord Thundered: "And you will realize that ( $\mathrm{x} \in \mathrm{e}$ 'your mind is ashes' (Wis 15:10)"

d. From Righteous Art Thou: “ $\chi \in \in$ 'Now who is my steadfastness? Isn't it the Lord? And my strength, isn't it with you?' (Ps 38:8 [7 Budge $\left.{ }^{309} ; 39: 7\right]$ ), as if you belong to the one who wrote these things"

Timbie proposed that the presence of a signal formula indicated that the quotation was from Scripture and not simply an allusion. She also noted that, when "Scripture" is signaled, Shenoute may

${ }^{308}$ The following examples and translations were taken from Timbie 2007: 630.

${ }^{309}$ Budge 1898. The edition of the London Psalter by Budge 1898 uses sometimes a different verse number from the CoptOT base text and LXX (sometimes different chapter and verse numbers). In this case, Budge's verse number is also shown as well as different chapter and verse numbers of the Masoretic Text. For the London Psalter, see Section 4.1. 
mean not only the canonical Bible but also other authoritative writings such as the Didache. ${ }^{310}$ In addition, "stock phrases" from the Bible (e.g., "fear and trembling" and "day of wrath") were frequently quoted without signaling formulae..$^{311}$

\subsubsection{Besa's (Zitat-)Einleitungen}

Behlmer examined the use of quotation signals (which she coined Einleitung) in Besa's works. ${ }^{312}$ Table 1 shows signals that appeared more than twice. Behlmer's research is wider-ranging than Timbie's and covers signals that Timbie omitted. She examined QIPs in the first 70 pages of the Kuhn edition as a case study. Certain QIPs were used very frequently, but there were many others.

\begin{tabular}{|c|c|c|}
\hline Einleitung & Translation & Frequency \\
\hline aYco ON $X \epsilon$ & and again: & 48 \\
\hline $\operatorname{ar\omega } x \in$ & and: & 40 \\
\hline$\overline{\text { N}} \Theta \epsilon \in$ єтсн $2(\chi \epsilon)$ & as is written(:) & 36 \\
\hline$\epsilon в о \lambda x \epsilon$ & Because & 14 \\
\hline Катапетснг Хє & according to what is written: & 12 \\
\hline $\bar{N} \Theta \epsilon \in$ enTAYXOOC $X \epsilon$ & as he said: & 11 \\
\hline
\end{tabular}

\footnotetext{
310 Timbie 2007: 630.

${ }^{311}$ Timbie 2007: 630.

${ }^{312}$ Behlmer 2004 (unpublished).
} 


\begin{tabular}{|c|c|c|}
\hline$(a Y \omega) \bar{N} \Theta \epsilon \in$ enTaYXXoc $X \epsilon$ & (and) as is said: & 10 \\
\hline Kal гар & for, namely & 6 \\
\hline 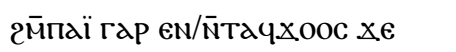 & for about this, he said: & 5 \\
\hline 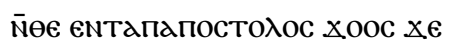 & as the Apostle said: & 5 \\
\hline КатапеNтаYХOOY ХE & according to what is said: & 5 \\
\hline aYo ON C)ayXOOC Xe & and he said again: & 5 \\
\hline 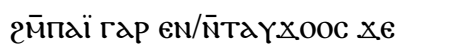 & for, about this it is said: & 4 \\
\hline КАТАחENTAYХOOY ХE & according to what he said: & 3 \\
\hline дуХOOC $\triangle \epsilon$ ON $\triangle \epsilon$ & he, however, said also/again: & 3 \\
\hline aYXOOC $\triangle \epsilon$ ON $X \epsilon$ & it was, however, said also/again: & 3 \\
\hline
\end{tabular}

Table 1: Einleitungen used by Besa to indicate quotations.

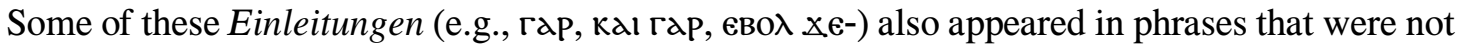
quotations. Such QIPs provided a useful way to detect quotations in Besa and Shenoute, but they were not infallible since they were not always used.

\subsection{Chapter summary}

The primary aim of this study is to clarify how Shenoute reuses texts. Chapter 2 established the two main types of research in this area: studies of text reuse and studies of intertextuality. Intertextuality research grew out of literature and philosophy research, while text reuse research originated from the field of computer linguistics. More recently, text reuse and intertextuality were combined into a single 
area of research: the digital text reuse analysis. Chapter 2 reviewed how both text reuse and intertextuality are approached in both research in general and Shenoute's works in particular.

In the latter, two types of signals used to indicate quotations were identified: quotation signals, quotation indicators, or quotative index phrases and particular grammatical forms. Additionally, dipless may be added to a text. However, these signals are insufficient for identifying all quotations, as Shenoute frequently incorporated passages from the Bible into his own works without giving any indications to his audience. ${ }^{313}$ Potentially, highly experienced biblical scholars would be able to recognize most or all intertexts of this type. The current research relies on cutting-edge technology that allows a wider group of scholars with less detailed knowledge on the Bible to investigate Shenoute's works through text reuse identification computer software. For this research, the TRACER software was selected to digitally detect text reuse. TRACER's effectiveness in parsing texts from the Bible and by Shenoute and Besa depends on thorough pre-processing and preparation of the electronic text corpus. The next chapter details how this can be achieved.

\footnotetext{
${ }^{313}$ Paul Dilley noted that Shenoute very likely dictated his works to a secretary. He cited a passage in
} Canon 2, where Shenoute states that he is weeping as he speaks and the brother who is writing down the words is also weeping (Dilley 2017: 79). 


\section{Methodology}

This chapter explains the approach used in the current research to detect intertextuality and text reuses.

\subsection{Projects}

\subsubsection{SFB 1136 and CoptOT}

The present research is part of a subproject of the Sonderforschungsbereich (SFB; Collaborative Research Centre) 1136 “Bildung und Religion in Kulturen des Mittelmeerraums und seiner Umwelt von der Antike bis zum Mittelalter und zum Klassischen Islam (Education and Religion in Cultures of the Mediterranean and Its Environment from Ancient to Medieval Times and to the Classical Islam)." SFB 1136 was funded from 2015 to 2020 by Deutsche Forschungsgemeinschaft (DFG; German Research Foundation) to study the intersection of religion and education in the Mediterranean sphere from Greco-Roman Antiquity to the Classical Islamic period in West Asia and North Africa and to the Medieval period in Europe. The period covered by SFB 1136 ranges from the fifth century BCE to the

\footnotetext{
${ }^{314}$ For more information about SFB 1136, the project website can be accessed at http://www.sfb1136.uni-
} goettingen.de/en/index.html, last accessed on October 13, 2021. 
16th century CE. The aim of the Coptological subproject, which was titled "Schriftauslegung und Bildungstraditionen im koptischsprachigen ägyptischen Christentum der Spätantike: Schenute, Kanon 6 (Biblical Interpretation and Educational Traditions in Coptic-speaking Egyptian Christianity of Late Antiquity: Shenoute, Canon 6)" was to produce a case study in which digital text reuse analysis is applied to Coptic monastic texts to clarify the function of quotations from and allusions to the Bible in Shenoute's Canon 6 and their possible role in monastic education. This work was based on the digital diplomatic edition of the relevant codices and involved gathering and digitizing photos of the manuscripts and transcribing and digitally annotating the texts of Canon $6 .{ }^{315}$

The images of the manuscripts were mainly taken from two photo collections of Coptic manuscripts of Corpus dei Manoscrtti Copti Letterari (CMCL) and Biblia Coptica, which are now kept by the Digital Edition of the Coptic Translation of the Old Testament project at the Academy of the Sciences and Humanities in Göttingen.

In this section, CMCL is first discussed, followed by Biblia Coptica. Around 1975, the CMCL project initially aimed to digitally reconstruct only the manuscripts from the White Monastery. However, it evolved to encompass all Coptic literature. ${ }^{316}$ In the 1980s, CMCL launched the digital version of its

${ }^{315}$ This study was funded to focus on a component of this larger project. In this capacity, the present author was formally working on this edition with Julien Delhez, and both of us were under the overall supervision of Heike Behlmer. The photos for the digital edition were gathered with help from Diliana Atanassova.

${ }^{316}$ See Orlandi 1990: 397-405. 
database, which was machine-readable. It became one of the foundational projects in codicological studies of Coptic literature, such as Emmel's reconstruction of Shenoute's literary corpus. ${ }^{317}$ Even today, the web version of the database provides essential information on the reconstruction of Coptic codices. It will eventually be superseded by a new project called PAThs (Tracking Papyrus and Parchment Paths: An Archaeological Atlas of Coptic Literature), which integrates its data. ${ }^{318}$

Initiated by Karlheinz Schüssler, Biblia Coptica was a project that aims to catalog and reconstruct the manuscripts of the Coptic Bible. ${ }^{319}$ After Schüssler passed away in 2013, Frank Feder and Hans Förster published the final volume in $2015 .{ }^{320}$ Subsequently, Feder and Siegfried Richter developed a new numbering system for Coptic manuscripts of the Bible. ${ }^{321}$ Biblia Coptica will be

${ }^{317}$ Emmel 2004c.

${ }^{318}$ Data from CMCL has now been moved to the PAThs project. The database and atlas can be found at the following URL: http://paths.uniroma1.it, last accessed on September 22, 2019.

${ }^{319}$ Schüssler 1995, 1996, 1998, 2000, 2001, 2003, 2004, 2006, 2007, 2009, 2010, 2011, and 2012.

${ }^{320}$ Schüssler 2015.

${ }^{321}$ See https://coptot.manuscriptroom.com/community/vmr/api/projects/coptot/lcbm/get/?format=html \&editClicks=true, last accessed on October 10, 2021. This webpage contains a table that shows the List of Coptic Biblical Manuscripts (LCBM) number, collection call number, content, CoptOT number, Schüssler's Biblia Coptica number, SMR (Schmitz-Mink-Richter) number, Horner sigla, and codex type/lectionary type of each Coptic OT manuscript. The SMR's (Schmitz-Mink-Richter; named after its creators) database can be found 
superseded by new digital projects in Coptic biblical studies. The Digital Edition of the Coptic Old Testament project (which is subsequently referred to as "CoptOT" in this study) is funded by the German Academy program and based at the Academy of Sciences and Humanities in Göttingen to create digital editions of all OT manuscripts in Sahidic Coptic. ${ }^{322}$ CoptOT will produce a critical edition of the Coptic Septuagint with translations in English, German, and Arabic. It is part of a network of digital initiatives in the field of Coptic studies. ${ }^{323}$ The Coptic NT is also being researched as part of the Editio Critica Maior of the Greek NT in Münster. ${ }^{324}$ Superseding Schüssler's numbering system for biblical manuscripts, ${ }^{325}$ both projects have led to the creation of a new shared system.

at SMR-Datenbank koptischer neutestamentlicher Handschriften des Projektes Novum Testamentum GraecumEditio Critica Maior der Nordrhein-Westfälischen Akademie der Wissenschaften und der Künst, http://intf.unimuenster.de/smr, last accessed on October 10, 2021. For the complete LCBM, see https://coptot.manuscriptroom.com/documents/10231/23535/LCBM_1.0_2021.pdf/dec4f073-dbfa-4af6-99713b2bace 5b3eb, last accessed on October 15, 2021.

322 The homepage of the Digital Edition of the Coptic Old Testament Project can be found at http://coptot.manuscriptroom.com, last accessed on October 10, 2021.

${ }^{323} \mathrm{http}: / /$ coptot.manuscriptroom.com/project-partners; http://kellia.uni-goettingen.de/partners.html, last accessed on October 10, 2021.

${ }^{324}$ The URL of the Editio Critica Maior homepage is https://www.uni-muenster.de/INTF/ECM.html, last accessed on October 15, 2021.

${ }^{325}$ As well as another previous system for the NT, see SMR — Datenbank koptischer neutestamentlicher Handschriften, http://intf.uni-muenster.de/smr, last accessed on October 15, 2021. 
The Coptic Old Testament project was the most important resource of the SFB 1136 subproject.

It currently holds the most extensive collection of digital surrogates of manuscripts in the field. Therefore, members of the SFB 1136 subproject could find nearly all photos of the manuscripts in Canon 6, except for a few fragments. ${ }^{326}$

For the diplomatic transcription and the philological annotation, the SFB subproject team used the Virtual Manuscript Room (VMR). The VMR was first developed by Troy A. Griffitts and Ulrich Schmid for a digitization project of manuscripts from the NT that involved the Institut für Neutestamentliche Textforschung (INTF) from the Faculty of Protestant Theology at Westfälische Wilhelms-Universität Münster and the Institute for Textual Scholarship and Electronic Editing (ITSEE)

${ }^{326}$ The present author made several trips abroad to look for manuscripts held at the British Library in London and in Washington, D.C., where he was permitted to go through Henri Hyvernat's photo collection at the Department of Semitic Studies at the Catholic University of America. The aim of my visit to the British Library and Henri Hyvernat's photo collection was to produce better transcriptions of MONB.XF pp.47-48. The SFB 1136 subproject only possessed unclear photos of MONB.XF pp. 47-48. This single folio is fragmentary, separated into two parts. The upper fragment is preserved at the British Library as Or. 6954(11). The bottom half of MONB.XF p.47-48 is in the Coptic Museum, Cairo (the inventory number is unknown), but Henri Hyvernat's photo collection contains the photos of the recto and verso pages as photos 87 and 88 respectively. Moreover, the photo collection has photos of the pages of Fragment 1a (the inv. 2631/111, Coptic Museum, Cairo, C.G. 9255 f. 1) as photos 7 and 8 . The SFB 1136 subproject did not have photos of this fragment. The photos from Henri Hyvernat's photo collection are approximately one century old, and were photographed by Henri Hyvernat. 
at the University of Birmingham. ${ }^{327}$ For the purposes of the SFB 1136 subproject, a subsite was established within the VMR. If older printed editions existed, the team extracted digital texts through optical character recognition (OCR). If old transcriptions of texts existed but were compiled using older ASCII fonts for Coptic, ${ }^{328}$ a Unicode converter was used to convert the ASCII transcriptions into Coptic Unicode. ${ }^{329}$ Both were then checked against photos of the original pages. This process is not fully complete at present, as some difficult-to-read pages are still awaiting collation. However, the overall results of this case study are not dependent on a complete diplomatic edition of every single fragment. Figure 12 shows a sample diplomatic edition of p. 13 of MONB.XV, which contains Shenoute's Canon 6 , in the VMR.

${ }^{327}$ For INTF, see http://ntvmr.uni-muenster.de, last accessed on October 12, 2021. For ITSEE, see https://www.birmingham.ac.uk/research/itsee/index.aspx, last accessed on October 12, 2021. For the development and methodology of the New Testament Virtual Manuscript Room using the VMR, see Schmid 2010 and Griffitts 2017.

${ }^{328}$ The digital transcription of Amélieneau's edition of Shenouteana was performed by Karl-Heinz Brune under the supervision of Stephen Emmel in Münster for the International Shenoute Translation Project, which is led by Emmel (p.c., Stephen Emmel). The SFB 1136 subproject used this digital transcription as the base text of some parts of Canon 6 after converting it into Unicode.

${ }^{329}$ It is called "recode_coptic.pl." See https://github.com/CopticScriptorium/converters/blob/master/ recode_coptic.pl, last accessed on September 22, 2019. 


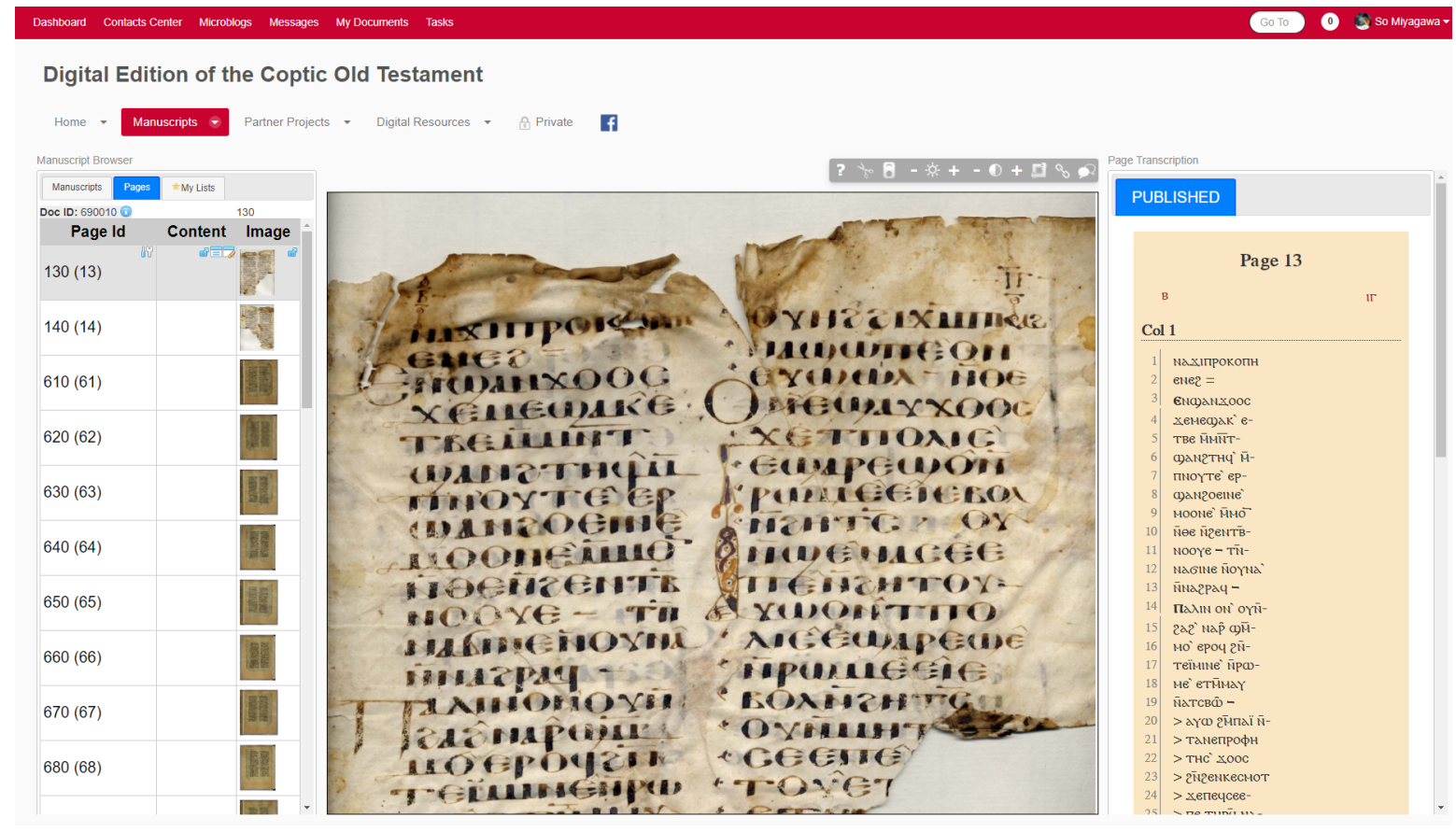

Figure 12: Representation of MONB.XV p. 13 on the Virtual Manuscript Room of the CoptOT project ${ }^{330}$

In fact, the creation of digital diplomatic editions of codices for Shenoute's Canon 6 and Besa's works was necessary for the SFB 1136 subproject. Still, its ultimate goal was to evaluate the value of digital text reuse analysis for the study of Coptic literary texts and the function of text reuses in Shenoute's educational discourse.

\subsubsection{KELLIA}

The tools and data used in SFB 1136 were made available by or adapted from various digital projects. The use of their tools and data was enabled by the collaboration of these projects, facilitated

\footnotetext{
${ }^{330} \mathrm{http}$ //coptot.manuscriptroom.com/manuscript-workspace/?docID=690010, last accessed on October
} 15, 2021 (access permission required). 
by the Koptische/Coptic Electronic Language and Literature International Alliance (KELLIA) umbrella project, which aimed to promote cooperation between digital linguistic and philological projects in Coptic Studies, establish common standards, and develop new digital humanities tools for the field. KELLIA was funded from 2015 to 2018 as a bilateral project by the DFG in Germany and the National Endowment for the Humanities from the United States. ${ }^{331}$

KELLIA produced several open-source products that are available on its GitHub repositories, such as Coptic Dictionary Online, Coptic NLP Service, and KELLIA E-ditions. ${ }^{332}$ KELLIA's main partner projects are SFB1136, CoptOT, eTRAP, ${ }^{333}$ INTF, the Database and Dictionary of Greek Loanwords in Coptic (DDGLC), ${ }^{334}$ and Coptic SCRIPTORIUM. Among them, the most important projects for the current research are eTRAP, Coptic SCRIPTORIUM, and CoptOT. Therefore, they are described in detail in the following subsections.

${ }^{331}$ The URL of the KELLIA project is http://kellia.uni-goettingen.de, last accessed on October 15, 2021. The present author coded and designed the webpage of the KELLIA project.

\footnotetext{
${ }^{332}$ For KELLIA’s products, see http://kellia.uni-goettingen.de, last accessed on October 12, 2021.

${ }^{333}$ eTRAP stands for Electronic Text Reuse Acquisition Project. For more on eTRAP, see Subsection
} 3.1.3.

${ }^{334}$ This lexicological project is currently based at the Free University of Berlin. For more details on DDGLC, see https://www.geschkult.fu-berlin.de/en/e/ddglc/index.html, last accessed on October 12, 2021. 


\subsection{3. $\quad$ eTRAP}

The Electronic Text Reuse Acquisition Project (eTRAP) was funded as an Early Career Research Group by Bundesministerium für Bildung und Forschung (BMBF) from March 2015 to December 2019 and hosted by the Institute of Computer Science in Göttingen. This group aimed to study text reuses as a literary and linguistic phenomenon using the TRACER software that it had been developing and to make this tool available to other digital humanities projects that could benefit from automatic detection (e.g., due to limited time, human resources, or massive amounts of data).

The development of TRACER as part of the eTRAP project began with Marco Büchler's 2013

doctoral thesis at the Faculty of Mathematics and Informatics at the University of Leipzig. ${ }^{335}$ The software was initially developed for Greek. TRACER and its high-performance computer, which can be remotely manipulated, were made available for the current research. ${ }^{336}$

${ }^{335}$ See Büchler 2013.

${ }^{336}$ See Büchler et al. 2008 for text reuse in the eAQUA project in detail. In addition, see Büchler 2008, Büchler and Geßner 2009, Büchler et al. 2010, and Büchler et al. 2014 for results or descriptions of TRACER processing in various projects. 


\subsubsection{Coptic SCRIPTORIUM}

Coptic SCRIPTORIUM, which stands for "Sahidic Corpus Research: Internet Platform for Interdisciplinary Multilayer Methods, ${ }^{, 337}$ is a project to produce multi-layered Coptic corpora that are linguistically and philologically richly annotated. ${ }^{338}$ It aims at creating "an open-source, open-access platform for interdisciplinary and computational research on texts in the Coptic language, particularly the Sahidic dialect. ${ }^{, 339}$ Coptic SCRIPTORIUM produces SGML and XML data for Coptic texts with linguistic and philological annotations and visualizes it on the corpus visualization platform ANNIS,

${ }^{337}$ The principal investigators of Coptic SCRIPTORIUM project are Caroline Schroeder and Amir Zeldes. For the concept and overview of the project, see Schroeder 2015 and Schroeder and Zeldes 2018.

${ }^{338}$ For multi-layer corpus method used in Coptic SCRIPTORIUM, see Zeldes 2018.

${ }^{339}$ Coptic SCRIPTORIUM's homepage can be found at http://copticscriptorium.org/, last accessed on October 15, 2021. First, it published fully linguistically annotated works by Shenoute and Besa online, such as Abraham Our Father and To Aphthonia, with parts of speech, columns, lines, page numbers on the manuscripts, and translations. Then, it added the Sahidica version of the NT by J. Warren Wells, which was automatically tagged; works by another monastic author, Apa John; more Besa texts; and Sahidic Bible 2.0's version of the Sahidic OT. See the Chrome addon for the versions of the Sahidic NT and OT edited by Askeland and Schulz at https://chrome.google.com/webstore/detail/sahidic-bible-askeland-sc/mbhdolnomjodfmgihfajipihojajgdjk, last accessed on September 22, 2019. 
which stands for "ANNotation of Information Structure." ${ }^{340}$ On ANNIS, users can see diplomatic editions like those of VMR, normalized transcription, parts of speech, the origins of words, translations, pages, columns, lines, and syntactic trees on the various layers. Furthermore, other layers can be added. Syntactic trees in Coptic SCRIPTORIUM are based on Universal Dependencies ${ }^{341}$ which is in turn based on the Stanford Dependency of Stanford University, ${ }^{342}$ the "universal part-of-speech tagset" developed by Google,${ }^{343}$ and the Interset interlingua for morphosyntactic tagsets. ${ }^{344}$ Universal Dependencies and Stanford Dependencies are dependency grammars that trace the dependency relation between two words. A dependency grammar does not presuppose phrases and units beyond the relation between two words. This point is crucially different from constituency grammars such as phrase structure grammar, ${ }^{345}$

${ }^{340}$ ANNIS can be downloaded at https://corpus-tools.org/annis, last accessed on October 15, 2021. For more details about the functioning, history, and methodology of ANNIS, see Krause and Zeldes 2016 and Zeldes et al. 2009.

${ }^{341}$ For details on Universal Dependencies, see http://universaldependencies.org, last accessed on October $15,2021$.

${ }^{342}$ See de Marneffe et al. 2006; de Marneffe et al. 2008a; de Marneffe et al. 2008b; de Marneffe et al. 2014.

\footnotetext{
${ }^{343}$ See Petrov et al. 2012.

${ }^{344}$ Zeman 2008.

${ }^{345}$ See Chomsky 1956: 117.
} 
generative grammar, ${ }^{346}$ head-driven phrase structure grammar, ${ }^{347}$ or categorial grammar, ${ }^{348}$ which admit larger units than a relation between two words, such as phrases with nodes.

On the ANNIS platform (see Figure 13), it is possible to search a specific word, a part of speech (POS), a type of word, ${ }^{349}$ combinations of words, constructions, and word of origin. In addition, statistical analysis can be performed.

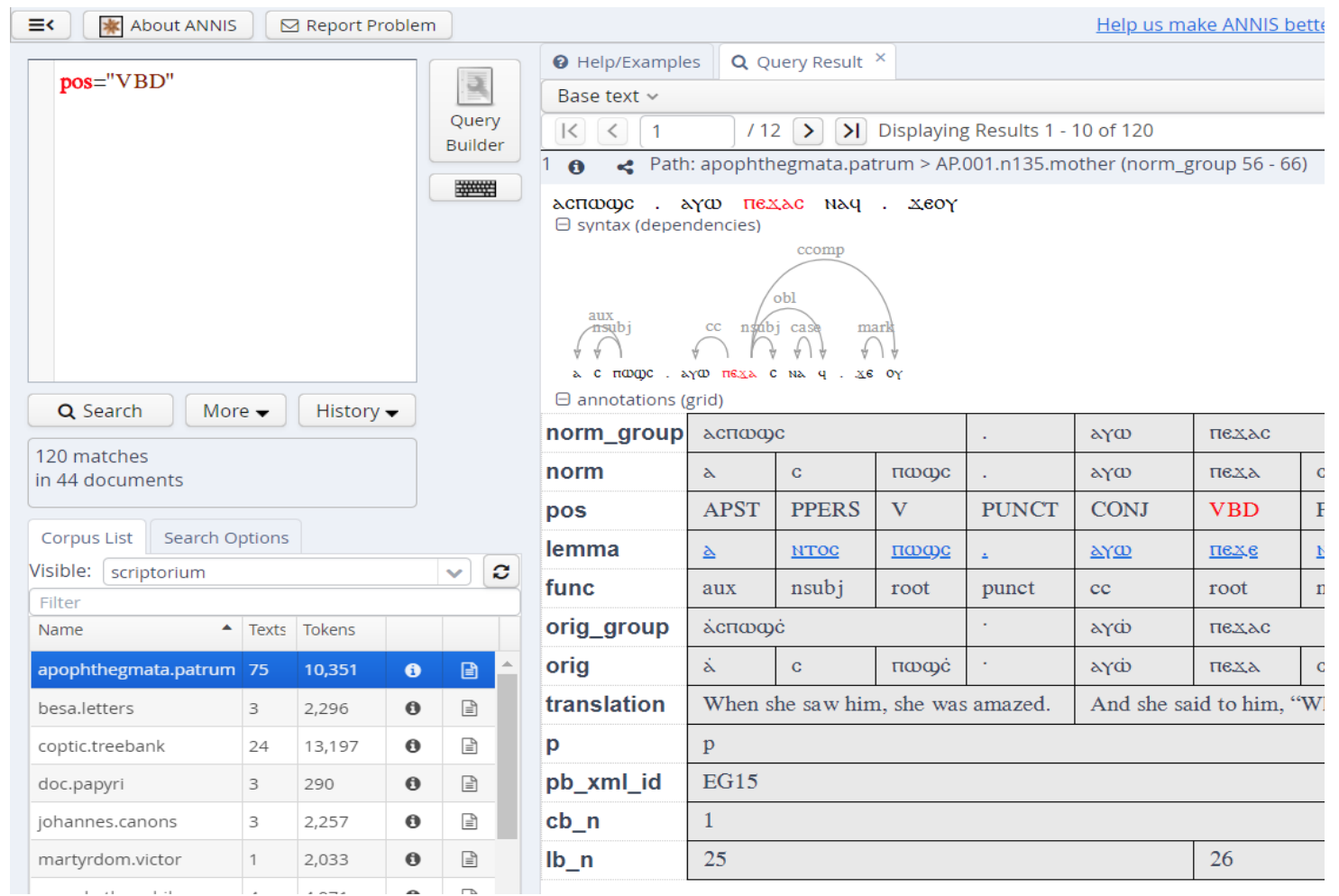

Figure 13: The corpus of Apophthegmata Patrum on the ANNIS portal. Users can search all verboids in the corpus using the ANNIS query language.

${ }^{346}$ See Chomsky 1965.

347 See Chomsky 1956: 117.

${ }^{348}$ Pollard and Sag 1994.

${ }^{349}$ Examples include Greek and Hebrew loanwords. 
Most data in Coptic SCRIPTORIUM is licensed under a Creative Commons (CC) BY license. ${ }^{350}$ Thus, users can reuse the resources that Coptic SCRIPTORIUM offers for free if they provide proper attribution. Furthermore, the project provides an online collaboration working platform called GitDox (see Figure 14), ${ }^{351}$ which allows multiple users to edit data from Coptic SCRIPTORIUM with a version

350 "BY" means "attribution." Under a CC BY license, users can reuse a product in their own work, but they must specify who made it. See an example of CC BY 4.0 on https://creativecommons.org/licenses/by/4.0/deed.en, last accessed on November 15, 2021. According to Coptic SCRIPTORIUM's GitHub repository (which can be found at https://github.com/CopticScriptorium/corpora, last accessed on October 15, 2021), all Coptic SCRIPTORIUM documents are licensed under CC BY 3.0 (https://creativecommons.org/licenses/by/3.0/us, last accessed on October 15, 2021) or CC BY 4.0 (https://creativecommons.org/licenses/by/4.0, last accessed on October 15, 2021). Some corpora also use a CC BY-SA license. "SA" means "shared alike." Users can reuse a product licensed under CC BY-SA in their own work, but they must provide the same license for their work. Corpora licensed under CC BY-SA in Coptic SCRIPTORIUM include the Canons of Apa Johannes (licensed under CC BY-SA 3.0, https://creativecommons.org/licenses/by-sa/3.0, last accessed on October 15, 2021) and the Sahidic OT (licensed under CC BY-SA 4.0, last accessed on October 13, 2021). Lastly, one exception does not have a CC license: the Sahidica New Testament, which has its own specific license. See http://www.copticscriptorium.org/download/corpora/Mark/coptic_nt_sahidic.html, last accessed on October 15, 2021.

${ }^{351}$ GitDox can be found at https://corpling.uis.georgetown.edu/gitdox, last accessed on September 22, 2019. 
management system called Git. On GitDox, the data can be directly edited on XML or on a spreadsheet using EtherCalc, ${ }^{352}$ as Figure 15 shows.

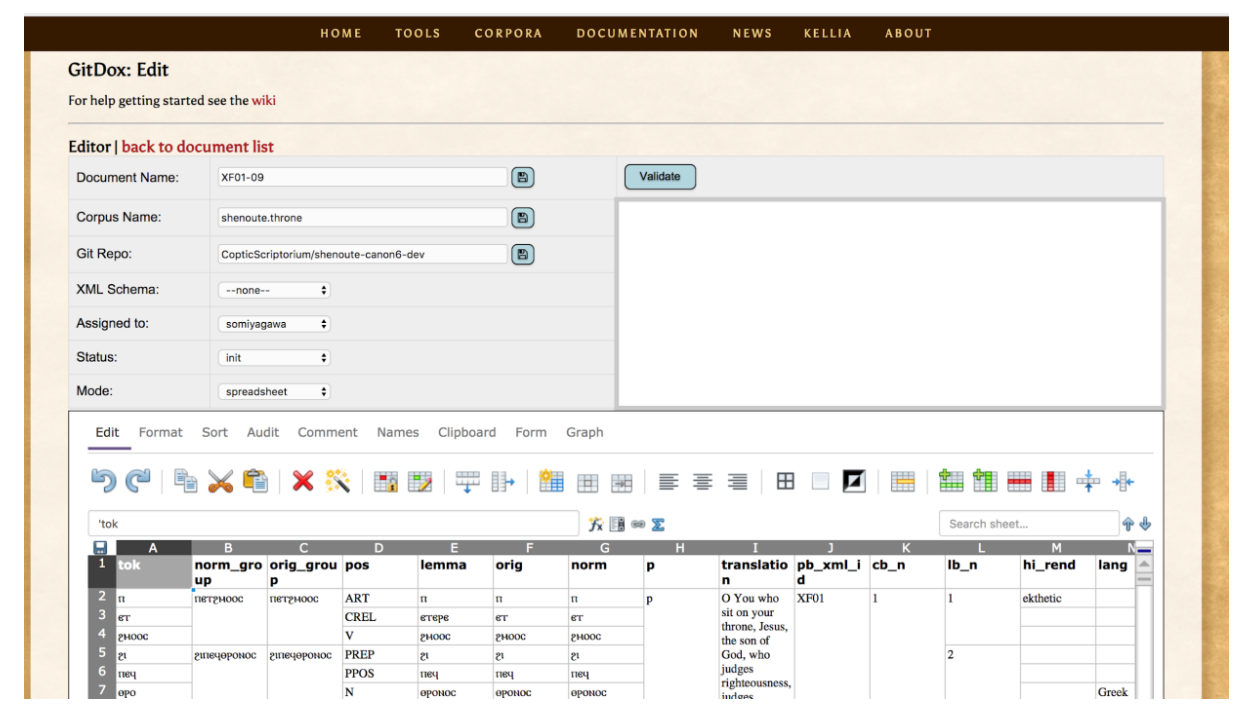

Figure 14: The GitDox user interface.

Using layers, Coptic SCRIPTORIUM can incorporate information about text reuses. Figure 15 show an attempt to display information about text reuses on the ANNIS platform. In the future, the text reuses found in the current research will also be displayed on Coptic SCRIPTORIUM.

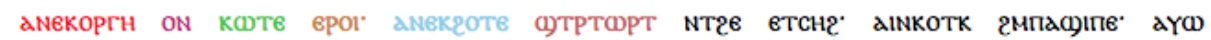

\begin{tabular}{|c|c|c|c|c|c|c|c|c|c|c|c|c|c|c|}
\hline \multicolumn{3}{|c|}{ aNEKOPTH } & \multirow{2}{*}{$\frac{\mathrm{ON}}{\mathrm{ON}}$} & \multirow{2}{*}{$\begin{array}{l}\text { кФTе } \\
\text { кळTе }\end{array}$} & \multicolumn{3}{|c|}{ epor" } & \multicolumn{3}{|c|}{ aneKrote } & \multicolumn{2}{|c|}{ Фтртсрт } & \multicolumn{2}{|c|}{ NT26 } \\
\hline a & NEK & оргн & & & 8 & pol & · & a & NeK & готе & Фтртюр & $T$ & $\mathrm{~N}$ & $\mathrm{~T}$ \\
\hline \multicolumn{3}{|c|}{ АNEKOPГH } & ON & кФTе & \multicolumn{3}{|c|}{ єpoï } & \multicolumn{3}{|c|}{ ANEKROTE } & \multicolumn{2}{|l|}{ 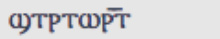 } & \multicolumn{2}{|c|}{ ผ̄ยย } \\
\hline \multirow[t]{2}{*}{ a } & NEK & оргн & ON & кФTе & 6 & poï & $\cdot$ & a & NeK & готе & Ф)тртюр̄ & $\bar{T}$ & $\overline{\mathbf{N}}$ & $\theta$ \\
\hline & & Greek & & & & & & & & & & & & \\
\hline
\end{tabular}

vrath has also surrounded me, your fears have troubled me, as it is written: I fell asleep in my shame and $\varkappa$, on the occasion of men who are not satisfied with sinning against their souls, from their beginning un

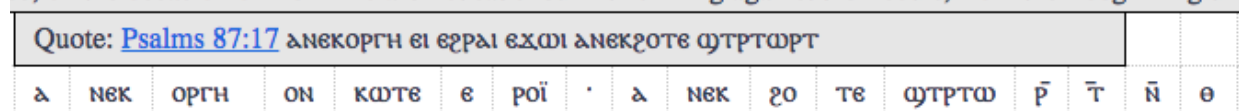

Figure 15: Importing TRACER results into ANNIS (taken from Miyagawa et al. 2018).

352 The URL of EtherCalc is https://ethercalc.net, last accessed on September 22, 2019. 
In addition, Coptic SCRIPTORIUM provides various tools that can be used to perform corpus linguistic analyses and the pre-processing needed for TRACER processing in the current research, which are described in more detail in Subsection 3.2.2.

\subsection{Process}

Generally, the application of digital tools to textual data takes place in three steps: preprocessing, processing, and post-processing. "Pre-processing" means preparation for processing. For this research, pre-processing consisted of preparation, cleaning, and normalizing plain texts generated from TEI XML files. As shown in Figure 16, the pre-processing stage included digitization through OCR processing, Unicode conversion, transcription, tokenization, normalization, and lemmatization. "Processing" refers to the main operation (i.e., running TRACER), while "post-processing" indicates any processes completed after the processing stage, such as visualization and correction.

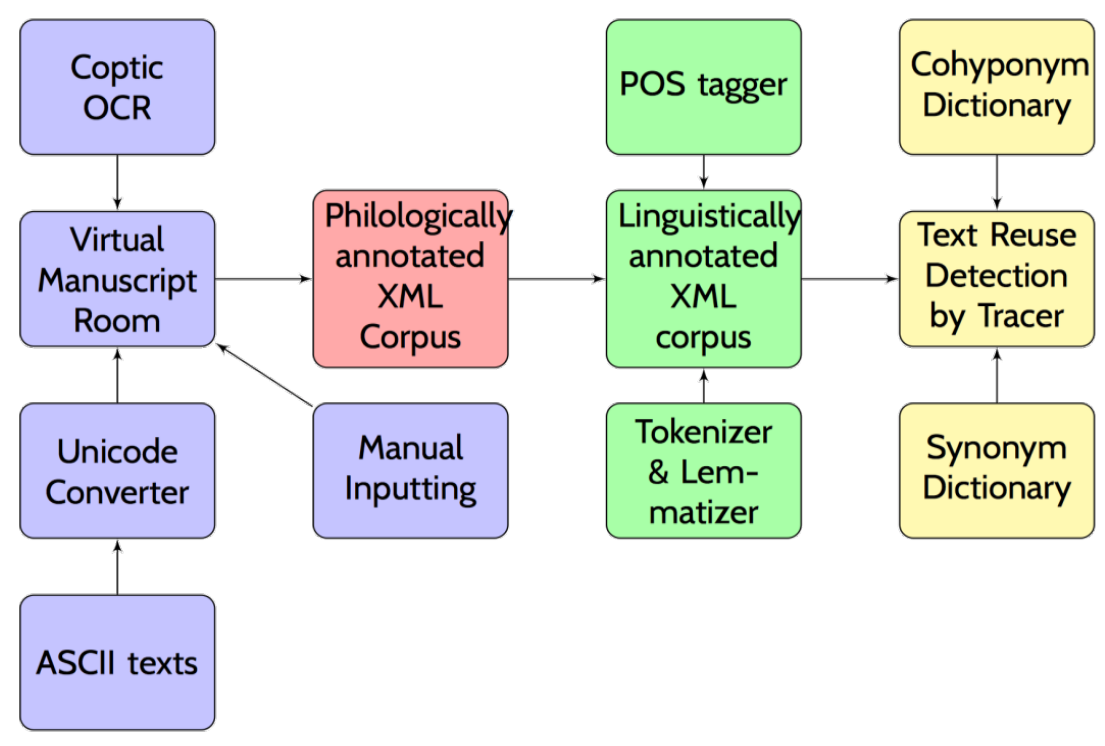

Figure 16: Outline of the pre-processing and processing stages. 
Before running TRACER, various pre-processing tasks had to be completed. They are colorcoded as follows in Figure 16:

(1) Blue: preparation and modification of digital transcriptions (Coptic OCR, Unicode Converter, and manual input) based on photographs of the manuscripts

(2) Red: editing of the transcriptions with philological tagging in the VMR

(3) Green: completion of linguistic analysis using the part of speech (POS) tagger, tokenizer, and lemmatizer tools provided by Coptic SCRIPTORIUM

(4) Yellow: use of co-hyponym and synonym dictionary data and TRACER to detect quotations in the tagged text corpus

Before describing each of the above steps, the projects that enabled this digital humanities procedure were examined. In this study, text reuse detection is performed on the target objects, namely the selected works of Shenoute, the works of Besa, and the Sahidic Bible. Pre-processing consisted of preparing transcriptions of texts from Shenoute's Canon 6, Besa, and the Coptic Bible with word segmentation. More specifically, OCR and Unicode Converter were used to compare the base text of the transcriptions with photographs of the manuscripts. Through OCR (see Subsection 3.2.1.1), Unicode texts of Kuhn's transcriptions of Besa's works and Leipoldt's transcription of parts of Shenoute's Canon 6 were created. Using the Unicode converter (see Subsection 3.2.1.3.1), the old ASCII transcriptions of parts of Shenoute's Canon 6 in Amélineau's edition, which were provided by Karl-Heinz Brune, were converted into Coptic Unicode text. The remaining transcriptions were manually inputted from printed editions. 
Through these three methods (i.e., OCR, Unicode conversion, and manual input), base texts were produced and imported into the VMR (see Subsection 3.2.1.2). Then, they were modified by examining and checking photos of the manuscripts, which were uploaded to the VMR server in a dedicated workspace provided by CoptOT. After modifying the base texts with philological information, a tokenizer, normalizer, and lemmatizer provided by Coptic SCRIPTORIUM (see Subsection 3.2.1.3.2) were used on the texts. Finally, the parsed texts were processed using TRACER. This TRACER process is discussed in more detail in Subsection 3.2.2.

\subsubsection{Pre-processing}

\subsubsection{OCR}

Uwe Springmann et al. demonstrated that OCR models can be developed for fonts or languages that do not yet have an OCR model by using only open-source programs. ${ }^{353}$ Springmann et al. laid the groundwork for examining the potential use of OCR on existing printed Coptic fonts, which could facilitate the transcription of manuscripts and text-based Coptological digital humanities work in general.

Kirill Bulert — who worked as a computer scientist in the eTRAP research group at the Institute of Computer Science - and the author of this dissertation aimed to develop a way to automatically produce Coptic text in Unicode from printed editions such as those in the Corpus Scriptorum

${ }^{353}$ See Springmann et al. 2014: 71-75. 
Christianorum Orientalium (CSCO) ${ }^{354}$ OCR is technology that can recognize and extract data from encoded digital characters in printed or handwritten texts. ${ }^{355}$ It seems to have first been attempted by Tito Orlandi in the 1980s. ${ }^{356}$ More recently, attempts to apply OCR to Coptic texts were undertaken by Moheb Mekhaiel. He focused on liturgical Bohairic texts using Tesseract, ${ }^{357}$ but OCR had not yet been applied to Sahidic texts. Amir Zeldes conducted a trial with OCRopus after an encounter with Uwe Springmann but did not develop it further. ${ }^{358}$ After participating in Springmann's OCR workshop in $2015,{ }^{359}$ Marco Büchler challenged Bulert and the author of the present dissertation to create OCR technology for Sahidic Coptic.

${ }^{354}$ For more information in the eTRAP project, see https://www.etrap.eu/team, last accessed October $12,2021$.

${ }^{355}$ OCR can be used for handwritten texts, but a new technology that specializes in the recognition of handwritten texts recently emerged: handwritten text recognition (HTR), which includes the recognition of ligatures and handwritten text alignments. The most successful and frequently used HTR software is Transkribus. See https://transkribus.eu/Transkribus, last accessed on October 15, 2021.

${ }^{356}$ P.c., Stephen Emmel.

${ }^{357}$ The Tesseract model trained by Moheb Mekhaiel can be downloaded at http://www.moheb.de/.

${ }^{358}$ Amir Zeldes mentioned his attempt to use OCRopus for Coptic during his conference presentation at Digital Coptic 2 at Georgetown University in Washington D.C. on March 12, 2015.

${ }^{359}$ A workshop called "OCR und Nachkorrektur alter Drucke für die Geisteswissenschaften / OCR and postcorrection of early printings for digital humanities" took place at the Centrum für Informations- und Sprachverarbeitung (CIS) Ludwig-Maximilians-Universität München on September 14 and September 15, 2015. 
Typically, there are two ways to recognize printed text and produce digital text from it. The first is to create an algorithmic model of the characters and match them to the characters in the image. The second is to use machine learning. For OCR, requirements for machine learning are (1) an original image, (2) so-called "ground truth" (i.e., data for training) and (3) a machine learning algorithm. Through the algorithm, the computer "learns" to match the characters in the original image and the Unicode characters in ground truth. After this period of learning, the computer can "read" an unknown text with experience from the "trained" model and produce a digital transcription. The advantage of this machinelearning approach is that it can recognize even noisy data and requires less preparation than nonmachine-learning approach.

The size of the Coptic alphabet is not a challenge for OCR: 24 Greek letters; an additional three numeral letters; and six, seven, or eight letters derived from Demotic, excluding the unique letters attested in Old Coptic and Proto-Theban or Dialect "P." ${ }^{, 360}$ In addition, diacritics include superlinear strokes, trema, circumflex, and punctuation marks such as the middle dot, comma, and an apostrophelike sign, which functions as a syllable divider. All these symbols (except for some unique signs used in documentary sources) are already available in Unicode Standard. The font used for this research was Antinoou due to its consistency with Unicode. ${ }^{361}$ For that, signs that only appear in documentary texts,

\footnotetext{
${ }^{360}$ For linguistic details about Dialect “P," see Kasser 1991.

${ }^{361}$ The Antinoou font is downloadable from the following webpage, which belongs to Michael Everson's
} website named EverType: “Antinoou: A standard font for Coptic," https://www.evertype.com/fonts/coptic, last accessed on October 15, 2021. 
it is advisable to use IFAO Grec Unicode ${ }^{362}$ because they are included in the Unicode Private Usage Area. However, since literary texts such as Shenoute and Besa's works do not have them, Antinoou is sufficient for transcribing them.

Improvements in the application of OCR programs to Coptic, which are described in the next subsection, are useful not only for the present study but also other Coptic digital humanities projects, which require the digitization of Coptic texts in Unicode. Thus, the use of OCR in Coptic texts contributes to the field of Coptic Studies as a whole.

\subsection{OCR engine}

At the beginning of their work on Coptic OCR, Bulert and the author compared and evaluated two available open-source OCR programs: Tesseract and OCRopus. Both are being extensively developed through crowdsourcing. Therefore, algorithms for recognition can quickly change.

Tesseract was created by Ray Smith at Hewlett Packard Labs in Bristol in the 1980s and 1990s. ${ }^{363}$ By 2006, its development was sponsored by Google. Tesseract underpins the OCR engine on

${ }^{362}$ The IFAO Grec Unicode font can be downloaded from https://www.ifao.egnet.net/publications/ outils/polices/\#grec, last accessed on October 15, 2021.

${ }^{363}$ For a comparison of Tesseract and OCRopy, see Miyagawa et al. 2019. The entire OCR program was run on ROEDEL, a high-performance computer of the Institute for Computer Science in Göttingen. ROEDEL has a 16-core processor, $128 \mathrm{~GB}$ of RAM, and a $42 \mathrm{~TB}$ hard disk drive. Its operating system is Debian 7, a Linux distro. 
Google Books. Initially, in December 2015, Bulert and the author found that Tesseract's recognition algorithm (Tesseract's version was 3.0.0 at that time) was font-based and needed detailed information input of character boxes consisting of the letter shape and Unicode code point. However, in the latest beta version, Tesseract began to incorporate artificial neural networks such as OCRopy. It now has a more sophisticated interface that uses VietOCR, ${ }^{364}$ while OCRopy and OCRocis use a terminal or command line interface.

OCRopus is an OCR package that uses recurrent neural networks. There are several variants or derivatives, such as OCRopy, the Python-based OCRocis, ${ }^{365}$ the simplified OCRopus package, and Kraken, which can be used for right-to-left languages such as Arabic. ${ }^{366}$ OCRopus was released by Thomas Breuel on April 9, 2007, as a project sponsored by Google. ${ }^{367}$ OCRopus itself uses an artificial neural network model based on deep learning architecture. It uses machine learning technology with algorithmic modeling of characters and matches them to characters in the target texts. OCRopus is also used for Google Book Search and was formerly funded by the Andrew W. Mellon Foundation and BMBF. It was originally written in $\mathrm{C}++$ but was rewritten in Python; this version is known as OCRopy.

${ }^{364} \mathrm{http}: / /$ vietocr.sourceforge.net/, last accessed on September 22, 2019.

${ }^{365} \mathrm{http}: / /$ cistern.cis.lmu.de/ocrocis/, last accessed on September 22, 2019.

${ }^{366}$ https://github.com/mittagessen/kraken, last accessed on September 22, 2019.

${ }^{367}$ As of October 2021, Breuel was working at NVIDIA Research. 
The latter is licensed under Apache License v2.0 and is available for download and collaboration on GitHub. $^{368}$

As discussed in a 2019 journal article by the present author, Bulert, Büchler, and Behlmer, ${ }^{369}$ OCRopus achieved better results than Tesseract, especially in its ability to recognize diacritical marks such as superlinear strokes. In addition, it benefited from a short setup time and ease of setup for Coptic. ${ }^{370}$ Mekhaiel's model had difficulty with Coptic texts, which contain diacritics, punctuation, and editorial signs. Tesseract (until ver. 3) needed manual input of letter shapes and corresponding Unicode code points beforehand, while OCRopus did not need any a priori information input, only training or practice with the font using its neural network model. Both tools are still under extensive development, and algorithms for recognition and analysis may change. Until now, Tesseract has used a font-based recognition approach, while the newest beta version can also incorporate artificial neural networks.

Coptic editions generally contain many diacritical signs such as superlinear strokes. Due to this and OCRopus' relative ease of use, this program was chosen to further develop the Coptic OCR. Recent development of Coptic OCR has been conducted by Eliese-Sophia Lincke, who used the latest version of OCRopy at the time. The accuracy rate of the model produced by OCRopy reached over $97.5 \%$ based

${ }^{368}$ OCRopy can be downloaded from its GitHub repository at https://github.com/tmbdev/ocropy, last accessed on October 15, 2021.

\footnotetext{
${ }^{369}$ Miyagawa et al. 2019.

${ }^{370}$ See Miyagawa et al. 2019.
} 
on validation data. ${ }^{371}$ Currently, Lincke is training Calamari, ${ }^{372}$ an OCR engine produced with TensorFlow based on the structure of OCRopus and the collaborating OCR4all project. ${ }^{373}$

For OCR of a mixed printed text of Coptic, Latin, and Greek alphabets, the author is currently training CITlab's HTR+ engine, ${ }^{374}$ which is based on PyTorch, a deep learning development program. The HTR+ engine was developed by the CITlab team at the University of Rostock. This engine is available with a graphical user interface using Transkribus developed by the University of Innsbruck. ${ }^{375}$

\subsection{Image and ground truth}

In 2015-2016, the present author and Bulert attempted to apply deep learning OCR technologies to Coptic printed texts. First, images of a part of Karl Heinz Kuhn's edition of Besa's works were processed. ${ }^{376}$ They were scanned in $600 \mathrm{dpi}$ and saved as TIFF images. Then, the scans comprising two pages of the book each were divided into single pages, and the pages were deskewed, the black-white

${ }^{371}$ See Lincke et al. 2019: 87.

${ }^{372}$ Calamari can be downloaded from its GitHub repository at https://github.com/Calamari-

OCR/calamari, last accessed on October 15, 2021.

${ }^{373}$ For adaptation of Coptic OCR models to OCR4all, see Lincke 2020.

${ }^{374}$ See https://readcoop.eu/glossary/htr-plus, last accessed on October 15, 2021.

${ }^{375}$ See https://readcoop.eu/transkribus, last accessed on October 15, 2021.

${ }^{376}$ Kuhn 1956a. 
balance was adjusted, and dust and meaningless dots were removed. On ScanTailor, the margins were set to yield OCR results. ${ }^{377}$

To use OCRopus, a ground truth must be produced; it consists of a baseline or guidance value, wherein a manual transcription of a few pages from a publication is compared with the original printed text. OCRopus includes a program that can create a template for ground truth data files from the image of the printed Coptic text. First, it binarizes the files into black and white and segments each line of the texts. However, it seemed preferable to use ScanTailor, an open-source tool that is suitable for processing image data into the most appropriate format for an OCR program. ScanTailor allows images to be binarized into black and white. It can also make margins, adjust the deskew of lines on images of texts, and reduces dust on images.

Then, after the images processed by ScanTailor are imported into OCRopy, OCRopy arranges the identification number to each line and creates text boxes under each line in a HyperText Markup Language (HTML) file called "correction.html." In this phase, one can also use OCRocis instead of OCRopy. OCRocis is a variant of OCRopus; it features a shortened process and more straightforward and integrated commands. Therefore, it was given preference for the preparation of Coptic data from the base text of Besa's Letters and Sermons edited by Kuhn. ${ }^{378}$

\footnotetext{
${ }^{377}$ The URL ScanTailor's website is https://scantailor.org/, last accessed on October 15, 2021.

${ }^{378}$ Kuhn 1956a.
} 


\subsection{Training}

After the segmentation of each line and inputting ground truth training data into "correction.html," OCRopy must be trained on the ground truth data. In this process, OCRopy learns the matching pattern between the Unicode characters and the characters that appear in the lines of printed text. The number of iterations in the training process is also essential. In the author's experience, the best number of iterations for Coptic is between 30,000 and 50,000. ${ }^{379}$ By default, OCRopy and OCRocis save a model after every 1,000 iterations of the training.

\subsection{Prediction and evaluation}

After the training process, images of all pages of the publication must be prepared for processing; all pre-processing tasks, such as binarization, splitting the original two-page scans into single pages, setting margins on the images, using ScanTailor, ${ }^{380}$ and segmenting lines of the text, must be completed. Then, the processing command must be used to run OCRopy or OCRocis with an already trained model. ${ }^{381}$ First, ocrevalutf8, an evaluation tool for OCR accuracy, was used to evaluate the

${ }^{379}$ Reul et al. 2018: 11 stated that there is usually no improvement of accuracy rate after 30,000 iterations for the automatic training process.

${ }^{380}$ ScanTailor is available at https://scantailor.org, last accessed on November 25, 2021.

${ }^{381}$ All models created in these sequences are open source and available on the KELLIA project's GitHub repository under a CC BY-SA 4.0 license: https://github.com/KELLIA/CopticOCR, last accessed on September $22,2019$. 
models' accuracy rate. ${ }^{382}$ The OCR results are shown in the same format as "ground truth" training data. The accuracy of diacritical marks, Roman alphabets, and punctuation marks were not considered (reproduced in gray in Figure 17).

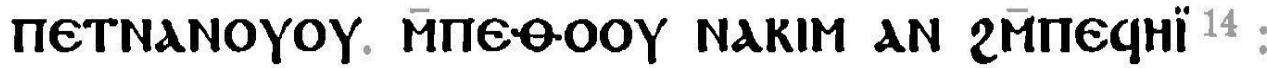 ATI BHCA}

\section{[Fragment 35̃] A DENUNCIATION OF AN ERRING NUN

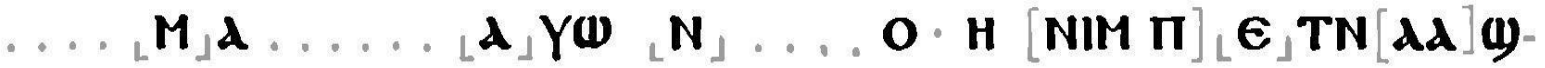

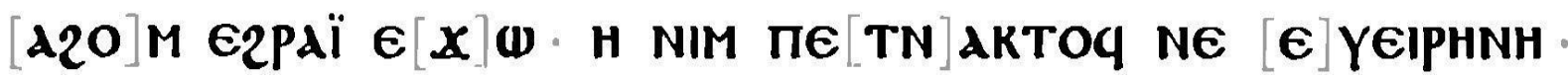

Figure 17: Recognized letters by OCRopy in a processed image from Kuhn 1956a: 115

(Miyagawa et al. 2019: i137).

The recognition model was trained to avoid the gray parts in Figure 17, which are superlinear stokes, editorial marks or non-Coptic letters.

Next, Figure 18 shows OCRopy results for some lines from Leipoldt and Crum's edition of the Bohairic Life of Shenoute. ${ }^{383}$ The additional $\mathrm{T}$ in program.

\footnotetext{
382 ocreval is available at https://github.com/eddieantonio/ocreval, last accessed on November 25, 2021.

${ }^{383}$ Leipoldt and Crum 1906: 7.
} 
output/0001/010001.bin.png

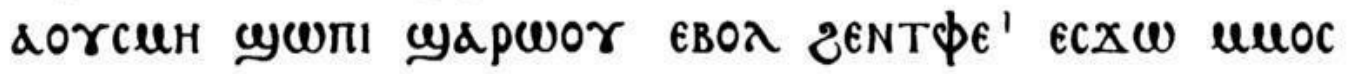

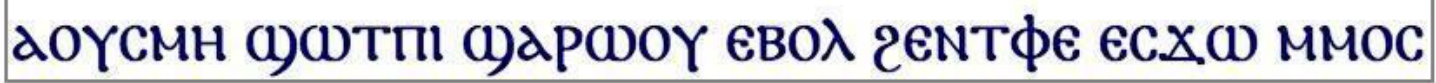

output/0001/010002.bin.png

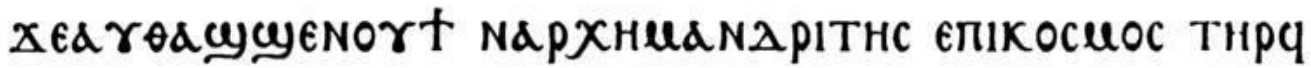

хеגYөגа)

output/0001/010003.bin.png

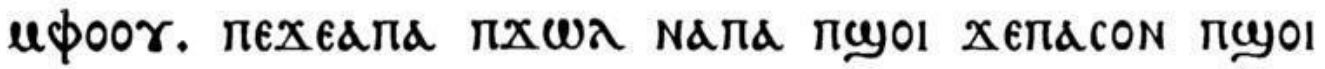

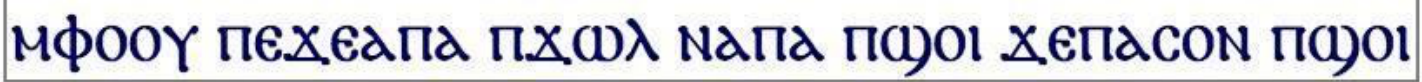

Figure 18: Sample OCRopy results.

In addition, Figure 19 shows how OCR accuracy changes with the amount of training. After 3,000 training iterations, the accuracy rate stayed fairly constant at over $90 \%$, with some minor exceptions. $^{384}$

${ }^{384}$ This training process was conducted in 2015 and 2016. In 2021, the accuracy rates shown in Figure 19 are considered relatively low in light of rapid and drastic developments in more recent machine learning technology. Results from 2016 and 2017 were described in Miyagawa et al. 2019. The latest and most accurate model was trained from 2018 to 2019 by Eliese-Sophia Lincke; see Lincke et al. 2019. 


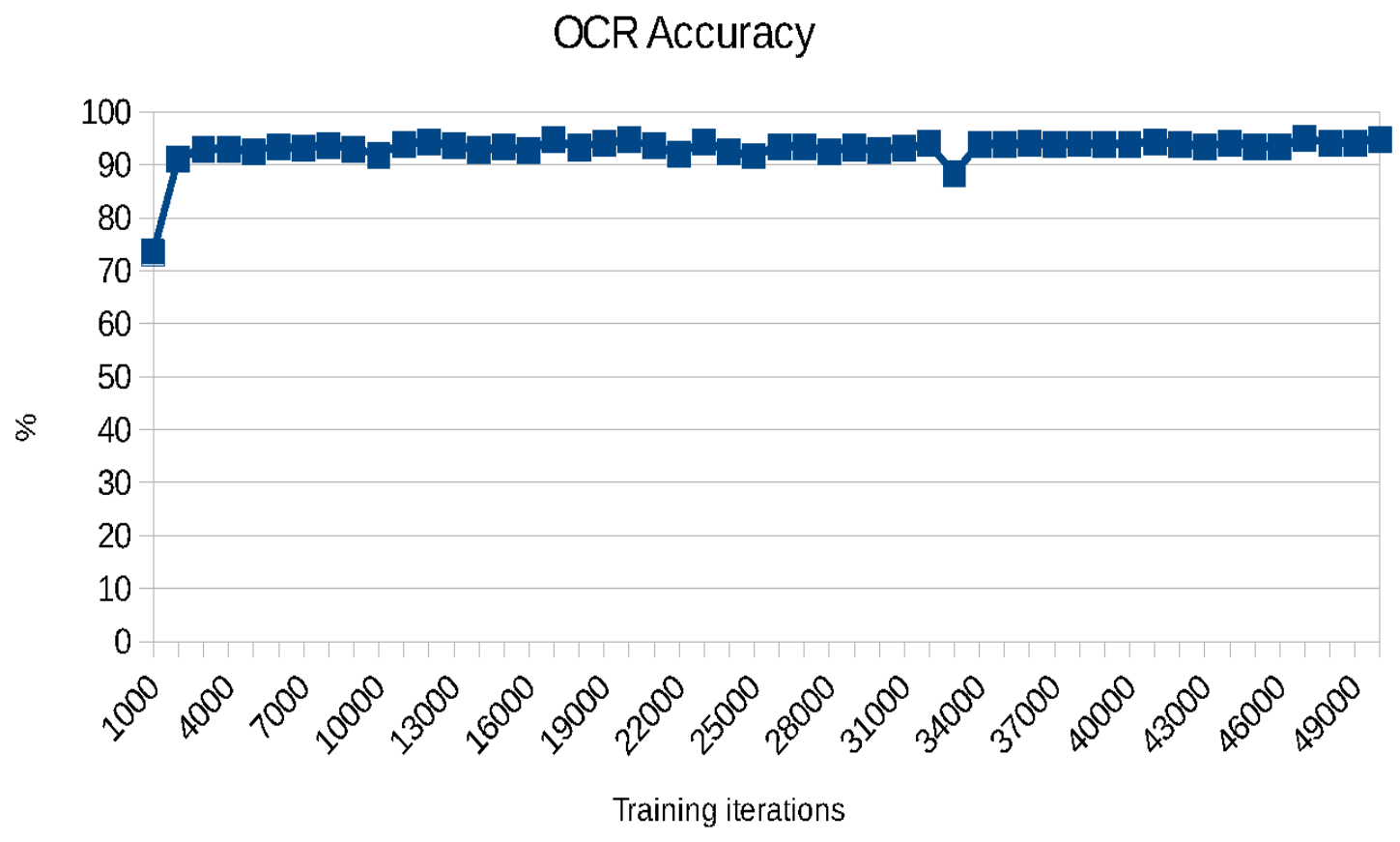

Figure 19: Results of OCR accuracy against training iterations (courtesy of Kirill Bulert).

Using either OCRopy or OCRocis, digital transcriptions were automatically extracted from parts of the text editions of Besa and Shenoute's works edited by Kuhn and Leipoldt, respectively. ${ }^{385}$ They were added to previously prepared manual transcriptions of large parts of Kuhn's edition.

\subsubsection{Virtual Manuscript Room}

To validate the results of the digital Unicode texts created by OCR or Unicode Converter and to correct them after comparisons with photographs of the manuscripts, the author used the Virtual

${ }^{385}$ See Kuhn 1956a for Kuhn's transcription of Besa’s Letters and Sermons. See Leipoldt and Crum 1908 and 1913 for Leipoldt's transcription of Shenoute's Canon 6. 
Manuscript Room (VMR). ${ }^{386}$ The VMR is a collaborative virtual research environment that contains several tools for transcription, annotation, and digital editing. It was originally developed by Troy Griffitts for the Greek NT and adapted for use with the Coptic Bible. ${ }^{387}$

Digitally generated manuscripts were added to the VMR on CoptOT's server using a specific API written in a special description format tagged with page numbers. The digital transcriptions were converted into this format through regular expressions. The VMR was chosen over another annotation tool called GitDox, ${ }^{388}$ which is also available for free online, ${ }^{389}$ and optimized for correcting linguistic annotations. However, since the current research only required validation and modification based on the manuscripts, the VMR was sufficient for its purposes.

The Unicode transcriptions produced using OCR, the font converter, and manual transcription were used as base texts. Then, in the VMR, errors generated through OCR, the Unicode converter, the transcribers of the published texts, or the original editor were modified. Philological information (e.g., page number, quire number, column number, line number, line break, column break, lacunae, and unclear letters) was tagged throughout this process.

${ }^{386}$ For details on the VMR, see Griffitts 2017. For details on CoptOT's VMR, see http://coptot.manuscriptroom.com, last accessed on October 11, 2021.

${ }^{387}$ The Virtual Manuscript Room Collaborative Research Environment (VMR-CRE) can be downloaded at https://vmrcre.org/, last accessed on October 15, 2021.

${ }^{388}$ See Zhang and Zeldes 2017.

${ }^{389}$ https://corpling.uis.georgetown.edu/gitdox/, last accessed on October 15, 2021. 
The VMR contains an editor that enables a team to collaborate on the transcription of Coptic texts, preferably using high-resolution digital images of manuscript pages and fragments. Photos of the manuscripts used in this research were mainly provided by CoptOT with help from Diliana Atanassova. ${ }^{390}$ When manuscript photos were missing, the author directly sought information from the holding institutions - in some cases, through autopsy of the originals. During the phase of transcribing Coptic manuscripts in the VMR, in addition to the correction process, philological information that is appropriate for Coptic and Greek manuscripts can also be tagged in the VMR and the data can be exported in TEI XML format.

The VMR contains several tiers. First, in the backend side (server side), it uses Git; this enables the VMR to retain each user's version history and effective collaborative work. Through the VMR interface, a user can see previous versions of the transcription and stages of the editing process saved on Git by team members. Griffitts, the server administrator, allowed the author to customize the layout of the editing apps. He created a portal called "SFB 1136 'Bildung und Religion' and KELLIA.” Then, the author created a new page called "Check." Here, the apps used on the VMR were called "gadgets." The present author arranged the one labeled "Catalogue-Browse and Search" on the upper left corner of the page. There, a user can select the codex and then the manuscript page. When one selects the manuscript page on the gadget "Catalogue-Browse and Search," the image of the manuscript page pops

${ }^{390}$ The CoptOT project's large archive of digital surrogates is based on photographic materials from the CMCL and the Biblia Coptica projects and is supplemented with purchased and freely accessible photos from manuscript collections around the world. 
up. Then one can transcribe it on the manuscript transcription editor on the upper right corner of the page, looking at the manuscript image.

The manuscript transcription editor was based on TinyMCE. ${ }^{391}$ The latter is "what-you-see-iswhat-you-mean" (WYSIWYM) ${ }^{392}$ and based on a TEI schema that uses a version of EpiDoc finetuned by ITSEE for the Editio Critica Maior (ECM). ${ }^{393}$ In addition, the VMR contains a visualization tool called CollateX for collations of variant readings. This function can be used to show the differences between parallels texts of Canon 6. However, since chapters and verses in Canon 6 have not been indexed, the potential of CollateX for Canon 6 has not yet been fully realized. ${ }^{394}$

${ }^{391}$ TinyMCE was developed by the Kompetenzzentrum Trier Center for Digital Humanities. See Kompetenzzentrum Trier, “Workspace for Collaborative Editing,” Universität Trier, 2018, http://kompetenzzentrum.uni-trier.de/de/projekte/projekte/collaborative-editing, last accessed on December 2, 2021. Trier's team and their work is based on the TinyMCE HTML editor working online, developed by the team led by Martin Sievers and Yu Gan, in collaboration with the ITSEE in Birmingham.

${ }^{392}$ For the definition of WYSIWYM, see Tom Mark 2002.

${ }^{393}$ This special EpiDoc schema was developed by Hugh Houston of ITSEE and adopted for the ECM. For more information on this editor, see Griffitts $2017, \S 4.5$.

${ }^{394}$ According to https://collatex.net (last accessed October 13, 2021), "CollateX is a software to read multiple ( $\geq 2$ ) versions of a text, splitting each version into parts (tokens) to be compared, identify similarities of and differences between the versions (including moved/transposed segments) by aligning tokens, and output the alignment results in a variety of formats for further processing, for instance to support the production of a critical apparatus or the stemmatical analysis of a text's genesis." 


\subsubsection{Coptic SCRIPTORIUM tools}

After correcting and exporting the data in plain text, normalization and tokenization must be performed using Coptic SCRIPTORIUM tools. ${ }^{395}$ Coptic SCRIPTORIUM made all its data and tools open source on GitHub to continue developing them through crowdsourcing. Coptic SCRIPTORIUM uses ANNIS, the web interface for text corpora based on PostgreSQL and Paula XML. To create corpora in the current version of Coptic SCRIPTORIUM, Zeldes and his collaborators have been developing tools to process Coptic texts. ${ }^{396}$

Coptic SCRIPTORIUM provides several tools, including a tokenizer, a normalizer, ${ }^{397}$ a POS tagger, ${ }^{398}$ a syntactic tagger, and an online pipeline that combines all the tools and a user-friendly web app with a graphical user interface called the Coptic NLP Service, which is a product of the KELLIA

\footnotetext{
${ }^{395}$ For a description of Coptic SCRIPTORIUM, see Subsection 3.1.4.

${ }^{396}$ For a list of Coptic SCRIPTORIUM's collaborators, see https://copticscriptorium.org/about, last
} accessed on October 12, 2021. There were 13 research members at Coptic SCRIPTORIUM as of October 13, 2021, including the author. Thus, he contributed to some of the tools, such as the Unicode converter.

397 “auto_norm.pl,” https://github.com/CopticScriptorium/normalizer/blob/master/auto_norm.pl, last accessed on September 22, 2019.

${ }^{398}$ Coptic SCRIPTORIUM originally adjusted Tito Orlandi's lexical data and published it on GitHub as “copt_lext.tab": https:/github.com/CopticScriptorium/tokenizers/blob/master/copt_lex.tab, last accessed on October 15, 2021. However, the lexicon data was enriched with Coptic Dictionary Online and DDGLC data. 
project. ${ }^{399}$ In this study, a Unicode converter, normalizer, and tokenizer were used; they are described in detail in the following subsections. For the text reuse detection undertaken as part of the research, the tokenizer was particularly indispensable.

\subsection{Unicode converter}

Previous projects, such as Tito Orlandi's CMCL, have accumulated digital transcriptions of Coptic texts in various ASCII-based fonts, which displayed the codepoints of the Latin alphabet as letters of the Coptic alphabet, i.e., only on the level of font, and not on the level of encoding. Thus, they were not platform-independent and required the right font to be installed for correct display. The digital transcriptions of Amélineau's two edited volumes of Shenoute's works use an ASCII font called “NagHammadi." ${ }^{400}$ Since 2013, Coptic SCRIPTORIUM has been developing "recode_coptic.pl, ${ }^{, 401}$ a converter program made in the programming language Perl that can transform Coptic ASCII fonts such as "Coptic," "CopticLS," and "avva_shenouda" into Unicode codepoints for Coptic. Using this converter, I converted the digital transcription of Amélineau's edition into Coptic Unicode. To facilitate the conversion of another widely used Coptic font, "NagHammadi," I added the codes to the converter

\footnotetext{
${ }^{399}$ For more on KELLIA, see Subsection 3.1.2. For more on the Coptic NLP Service, see Subsection
}

3.2.1.3.2. as well as Zeldes and Schroeder 2016a.

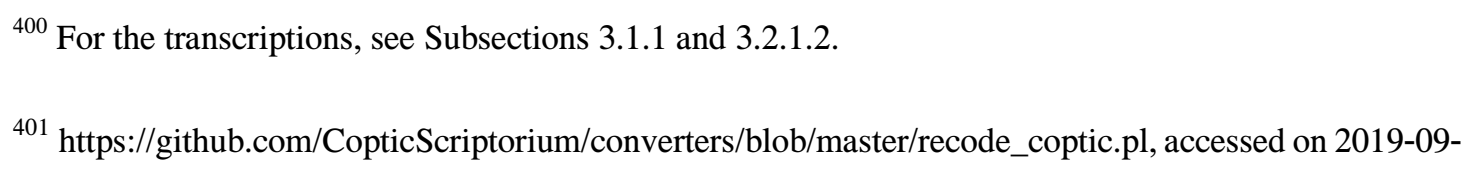


to convert it into Coptic Unicode. This program, which the author launched in 2013, is written in Perl and is still being improved on GitHub. It can be run on the Command Line on Windows, Terminal on Mac, or Console on Linux. ${ }^{402}$ To run the converter, the following command must be entered into one of the abovementioned programs:

recode_coptic.pl -f FONT-NAME INPUT-FILE-NAME > OUTPUT-FILE-NAME

For "FONT-NAME," the user can choose between Coptic, CopticLS, CMCL, NagHammadi, low, and avva_shenouda. Any name can be used for "INPUT-FILE-NAME" and "OUTPUT-FILENAME."

\subsection{Lemmatization}

In addition to Unicode conversion, tokenization, and normalization, Coptic SCRIPTORIUM provides lemmatization and POS tagging. All processes except Unicode conversion can be performed by Coptic SCRIPTORIUM's Coptic natural language processing (NLP) service by pasting Coptic text into the provided text box and clicking the "Process" button. ${ }^{403}$ Figure 20 shows automatic tagging of linguistic information using the Coptic NLP service.

\footnotetext{
402 The user must install Perl on the computer beforehand.

${ }^{403}$ This web application is a product of the KELLIA Project. See KELLIA's website at
} https://kellia.uni-goettingen.de, last accessed on October 8, 2021. 
$a<$ hi rend $=$ "red" $>$ Y $</$ hi $>$ covTM NCOY $\bar{N} \sigma$

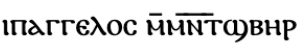

Process

Result:

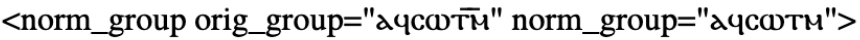

<norm xml:id="u1" pos="APST" lemma="ג" func="aux" head="\#u3" orig="a" norm="ג">

$<$ hi rend="red">

$</$ norm $>$

<norm xml:id="u2" pos="PPERS" lemma="NToq" func="nsubj" head="\#u3" orig="q" norm="ч">

4

$</$ hi $>$

$</$ norm $>$

$<$ multiword multiword="cotm NCd">

$<$ norm xml:id="u3" pos="V" lemma="cotM" func="root" orig="coTT" norm="cotM">

$\operatorname{coTM}$

$</$ norm $>$

$</$ norm_group $>$

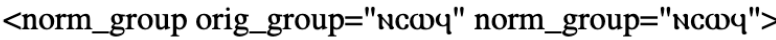

<norm xml:id="u4" pos="PREP" lemma="ncd" func="case" head="\#u5" orig="Ncw" norm="Ncw"> NCON

Figure 20: The Coptic NLP Service parsing a Coptic text morphologically and syntactically. ${ }^{404}$

For the purposes of TRACER, it is not necessary to provide lemmatization and POS tagging through the NLP pipeline, since both can be provided by TRACER itself. The program can be given a "dictionary" file containing the actual form in the first column, the lemma in the second column, and POS in the third column. This file must follow the Morpheus format. ${ }^{405}$

${ }^{404}$ https://corpling.uis.georgetown.edu/coptic-nlp, last accessed on October 15, 2021.

${ }^{405}$ See Celano et al. 2016: 393-94. The present author applied the Morpheus format to the POS tags of Coptic SCRIPTORIUM and used it for pre-processing of the corpus; see Appendix. 


\subsubsection{TRACER}

TRACER is an open-source Java program developed by the eTRAP research group. ${ }^{406}$ As described in Subsection 3.1.3, TRACER was designed to automatically detect text reuses. The team used ROEDEL, a high-performance computer that the present author and Bulert have used for OCR, ${ }^{407}$ for TRACER processing. ROEDEL can be remotely accessed using ssh, screen, and scp commands on Terminal on Macs, Command Line on Windows, or Console on Linux. TRACER encompasses more than 700 algorithms that can be divided into six levels. A user can adjust these algorithms by changing parameters in the configuration XML file, which is called "config.xml." Figure 21 shows TRACER's entire workflow, including all levels of pre-processing, processing, and post-processing. The next subsections describe these levels in greater detail.

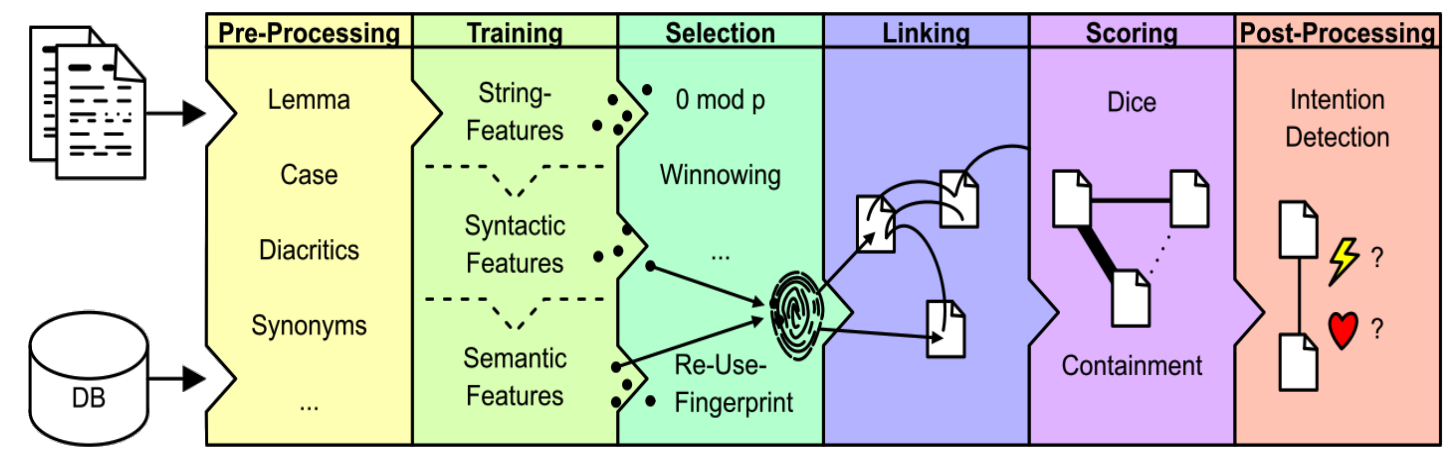

Figure 21: TRACER workflow (courtesy of eTRAP).

406 TRACER is freely available for download from eTRAP's GitLab repository

(http://vcs.etrap.eu/tracer-framework/tracer.git, last accessed on August 8, 2021).

${ }^{407}$ See Subsection 3.2.1.1. 


\subsubsection{Level 1: Pre-processing}

Level 1 of TRACER's workflow focuses on pre-processing. In this level, diacritical signs or punctuation marks can be deleted, and scriptura continua or scriptio continua can be divided into words or morphs using spaces. Level 1 represents a vital preparation phase for processing in TRACER. There are two levels of pre-processing: letter-level pre-processing and word-level pre-processing.

In letter-level pre-processing, letters (more precisely, Unicode characters) in the corpora to be processed are modified to increase their suitability for TRACER processing. For example, the "boolReplaceWhitespaces" algorithm puts white spaces between words for the text of scriptura continua. The "intNGramSize int = integer" algorithm divides and puts spaces for every given number of characters and treats every divided chunk as a word. The "boolRemoveDiacritics" algorithm removes diacritics.

However, it is better to use Coptic SCRIPTORIUM tools rather than TRACER's built-in tools to normalize the text, as Coptic contains special diacritics. These include various types of superlinear strokes, which "boolRemoveDiacritics" cannot process. Finally, the "boolMakeAllLowerCase" algorithm converts all the capital letters into small letters. However, Coptic SCRIPTORIUM's normalizer can be used instead of "boolRemoveDiacritics," and its tokenizer can be used instead of "boolReplace Whitespaces" and "intNGramSize int = integer." Therefore, the above-mentioned algorithms are not needed for letter-level pre-processing.

Word-level pre-processing includes natural language processing techniques, such as lemmatization, and semantically deeper processes, such as synonym and co-hyponym analysis that uses 
data from a semantic network database (e.g., a wordnet). Co-hyponyms are words that share the same hypernym. For example, orange juice and apple juice are co-hyponyms with the hypernym juice.

The word-level pre-processing stage also has its own algorithms. For instance, "boolLemmatisation" converts all inflected forms into a base form (i.e., lemma), which is listed in the "BASEFORM_FILE_NAME" property. The algorithm is important for inflected languages such as ancient Greek but also can be used for the "status" of Coptic words: "status absolutus," "status nominalis," and "status pronominalis," used for the states of boundedness of Coptic words. Data from Coptic SCRIPTORIUM's lemmatizer can be combined with the "boolLemmatisation" algorithm. In this study, data from Coptic SCRIPTORIUM's lemmatizer were used as BASEFORM_FILE, which contains all the word forms in one column and their lemmata in another column. Using this file, TRACER lemmatized all three statuses into a single lemma and treated stative verbs as independent lemmata. In addition, "boolLemmatisation" requires plain POS tagsets (e.g., Morpheus-based tagsets), which are simpler than those of Coptic SCRIPTORIUM. ${ }^{408}$ Therefore, the author converted Coptic SCRIPTORIUM's fine POS tagset into a Morpheus-based simple POS tagset. The Appendix of this study shows correspondences between the two types of tagsets.

For detecting text reuses with synonymic or co-hyponymic changes, the "boolReplaceSynonyms" algorithm compares all words with synonyms listed in the "SYNONYMS_FILE_NAME" property. This is not only valid for synonyms but also co-hyponyms. This algorithm can also be combined with a database of a semantic network of lexemes, such as

${ }^{408}$ Celano et al. 2016: 393-99. 
wordnets ${ }^{409}$ or BabelNet ${ }^{410}$ to import data on synonyms and hyponyms into TRACER. Thus, TRACER detects text reuses with paradigmatic alternations in synonyms or co-hyponyms.

Currently, a team is developing the Coptic wordnet ${ }^{411}$ using data from the Coptic Dictionary Online written in TEI XML ${ }^{412}$ and Marcion written in MySQL. ${ }^{413}$ In the future, this will refine text reuse detection results, especially for semantic text reuse. ${ }^{414}$

${ }^{409}$ The first version of the wordnet was the WordNet, an electronic conceptual dictionary of English produced by the University of Princeton; see https://wordnet.princeton.edu/, last accessed on September 23, 2021. After the original wordnet, equivalents were produced in various languages; many are registered at the Global Wordnet Consortium. For more on the WordNet and the Global Wordnet Consortium, see Fellbaum 2005. Usually, "WordNet" is used as a proper noun for the first wordnet, while "wordnet" is used as a common noun. However, they were often confused, especially during the early history of wordnets (p.c., Laura Slaughter).

${ }^{410} \mathrm{https}$ ://babelnet.org, last accessed on October 15, 2021.

${ }^{411}$ The team includes Laura Slaughter of the University of Oslo, Luís Morgado da Costa of Nanyang Technological University, and the author. It is developing the Coptic wordnet from data provided by the Thesaurus Linguae Aegyptiae at Berlin-Brandenburg Akademie der Wissenschaften and the DDGLC project. See Slaughter et al. 2019.

${ }^{412}$ https://corpling.uis.georgetown.edu/coptic-dictionary, last accessed on October 15, 2021.

${ }^{413} \mathrm{http} / / /$ marcion.sourceforge.net, last accessed on October 15, 2021.

${ }^{414}$ The TRACER processing described in Chapter 5 could not yet use the Coptic wordnet. 


\subsubsection{Level 2: Featuring}

Level 2 of TRACER's workflow is featuring and training, which involves training TRACER in string features, syntactic features, and semantic features. Featuring is a process for comparing more than two texts; there are several methods of comparison, including word-based, bigram-based, trigram-based, and up to tengram-based. The featuring method is shingling (overlapping) or hash breaking. For example, in bigram shingling, [I like], [like the] and [the cat] in the sentence "I like the cat" are bigrams. In trigram shingling, TRACER would divide the sentence into two trigrams: [I like the] or [like the cat]. In bigram hash breaking, TRACER would dissect the sentence as two bigrams: [I like] and [the cat]. In wordbased shingling, TRACER would divide it into four words: [I] [like] [the] [cat], selecting words individually. For Coptic, Büchler chose word-based shingling.

\subsubsection{Level 3: Selection}

Level 3 of the TRACER workflow is intended to eliminate stop words (i.e., words that are not important to the corpus analysis). This prevents them from affecting the results of the text reuse detection. At this level, the local max pruning algorithm was used in TRACER to erase the most frequent tokens, which are often function morphs such as articles and prepositions. For selecting tokens to be analyzed, two approaches can be used: local selection and global selection. In text reuses between Shenoute's 
Canon 6 and the Psalms, and between Besa's Letters and Sermons and the Psalms, local max pruning was used with a feature density of $0.7 .^{415}$

\subsubsection{Level 4: Linking}

Level 4 of the TRACER workflow creates links between portions of two corpora that share similarities. The algorithm calculates the number of overlapping units. If it does not find a significant number of text reuses, the "moving window" method can be used to divide the corpus into 10 to 15 grams and re-analyze text reuse. Thus, text reuses with a small number of characters can be found. For Coptic, Büchler set the moving window to 15 grams, while the similarity threshold for Broder's resemblance was set to $0.5 .^{416}$

There are three ways of linking similar texts at this level: the first analysis works on the untokenized text, the second on the morphs, and the third on the morphs with a moving window of 10 to 15 tokens. A window contains sequential tokens as a string ${ }^{417}$ and moves by one morph. This moving window analysis is similar to the $\mathrm{N}$-gram analysis, but it usually takes more tokens than the latter. In addition, $\mathrm{N}$-gram analysis is conducted on text that the moving window analysis was already used on.

\footnotetext{
${ }^{415}$ Feature density here roughly means how many similar features the two passages share.

${ }^{416}$ Broder's resemblance is a method for measuring textual resemblance developed by Andrei Z.
}

Broder. See Broder 1997.

${ }^{417}$ Most of the tokens are equivalent to morphs. 


\subsubsection{Level 5: Scoring}

Scoring is used to judge the validity of the similarity detected between texts. There are two judging methods: absolute overlap and weighted overlap. The former identifies text reuses that share more than 13 elements, and the latter shows a percentage that expresses the degree of shared elements in a text reuse. Thus, the value of the text reuse similarities is numerically calculated.

\subsubsection{Level 6: Post-processing}

Level 6 of the TRACER workflow relates to post-processing and visualization. In this study, the visualization was conducted in a program called TRAViz. ${ }^{418}$ The latter uses the score file from the TRACER processing results to produce visualizations conveyed via HTML. This generates three types of visualization for text reuses using JavaScript, HTML, and CSS. By setting up the HTML, CSS, and JavaScript files on their own web server, the results can be published as interactive web pages. The dot plot view in TRAViz displays the locations of text reuses in a distribution graph with yellow and green circles. A green circle denotes a text reuse candidate with high similarity, and a yellow circle a text indicates a text reuse candidate with low similarity. If a circle is clicked, the collation view pops up; the two texts are shown as two parallel lines. Different words are depicted as parallel nodes, while the nodes for exact shared words are overlapping.

${ }^{418}$ TRAViz was developed by Stefan Jänicke of the University of Leipzig. See Jänicke et al. 2015. 


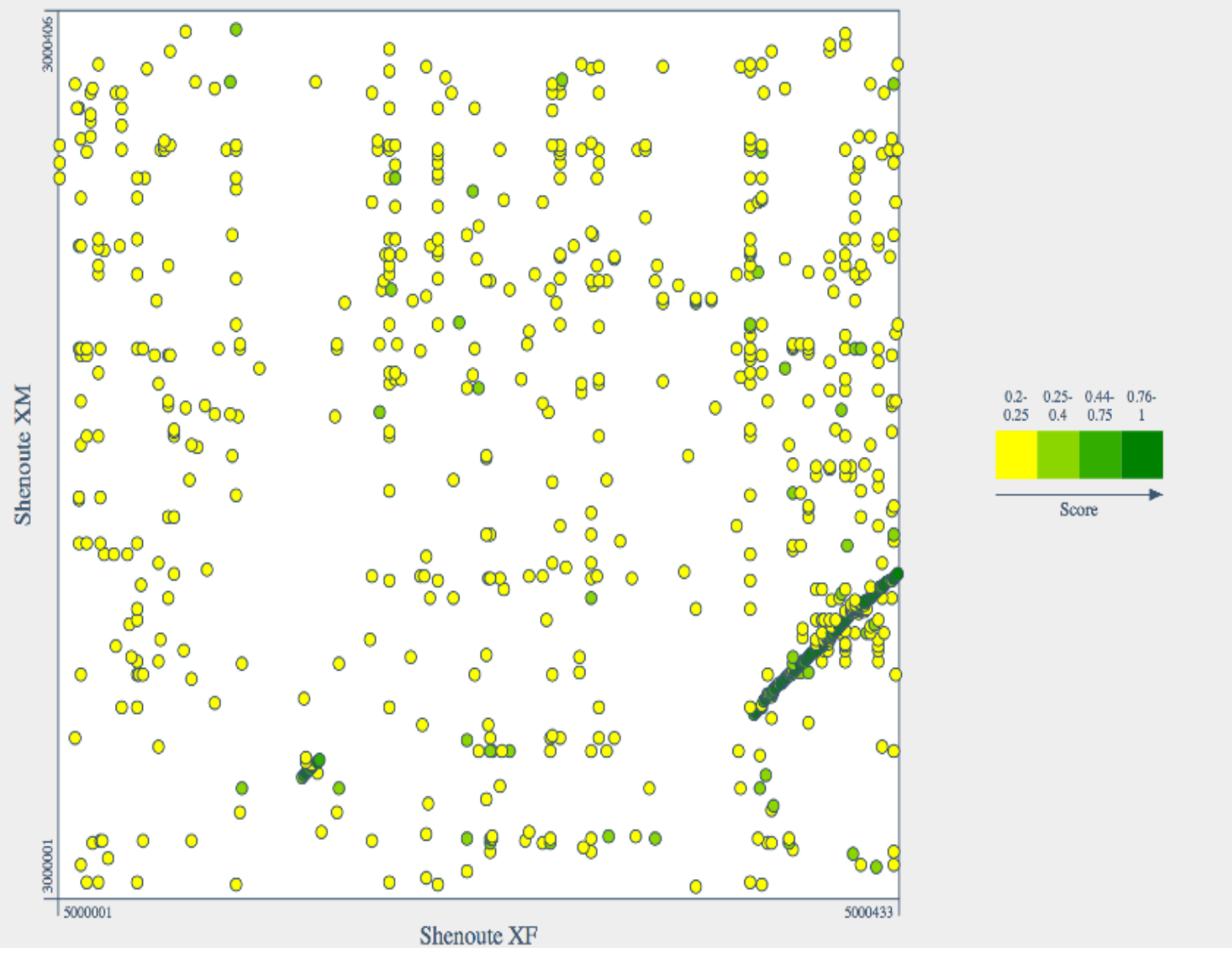

Figure 22: Dot plot view in TRAViz.

Figure 22 is an example of the dot plot view. ${ }^{419}$ In Figure 22, MONB.XF was set on the X-axis, and MONB.XM was set on the Y-axis. Then, the text reuse candidates between these texts were plotted. The left edge of the X-axis represents the beginning of MONB.XF and the right edge represents its end. Similarly, the bottom edge of the Y-axis represents the beginning of MONB.XM, which contains

${ }^{419}$ Here, the author would have liked to show a dot plot view of a comparison between Shenoute's

Canon 6 or Besa's Letters and Sermons and Psalms. However, this was too difficult, as the Y-axis (Psalms) would have been much longer than the $\mathrm{X}$-axis, as shown in Figure 22. Thus, examples that were well-balanced in terms of length were chosen instead: Shenoute's MONB.XM and MONB.XF. 
Shenoute's Canon 6, and the top edge represents its end. Yellow circles denote less similar text reuse candidates, and green circles indicate more similar text reuse candidates. Figure 22 illustrates that MONB.XM and MONB.XF share parallel text at the end of MONB.XF and from the middle to the end of the first half of MONB.XM, which has already been confirmed through manual comparison. Users can adjust the circle sizes by horizontally moving the electronic slider knob in "circle sizes" and reduce the number of circles by horizontally moving the electronic slider knob in "thinning." In addition, duplicate instances can be deleted by unchecking a box labeled "duplicates."

TRAViz provides another way of visualization of text reuse candidates. Text reuse alignment visualization shows parallel texts that share morphs (see Figure 23). The red line represents the text on the $\mathrm{Y}$-axis, and the blue line represents the text on the $\mathrm{X}$-axis. If a morph is shared, the red and blue lines overlap.

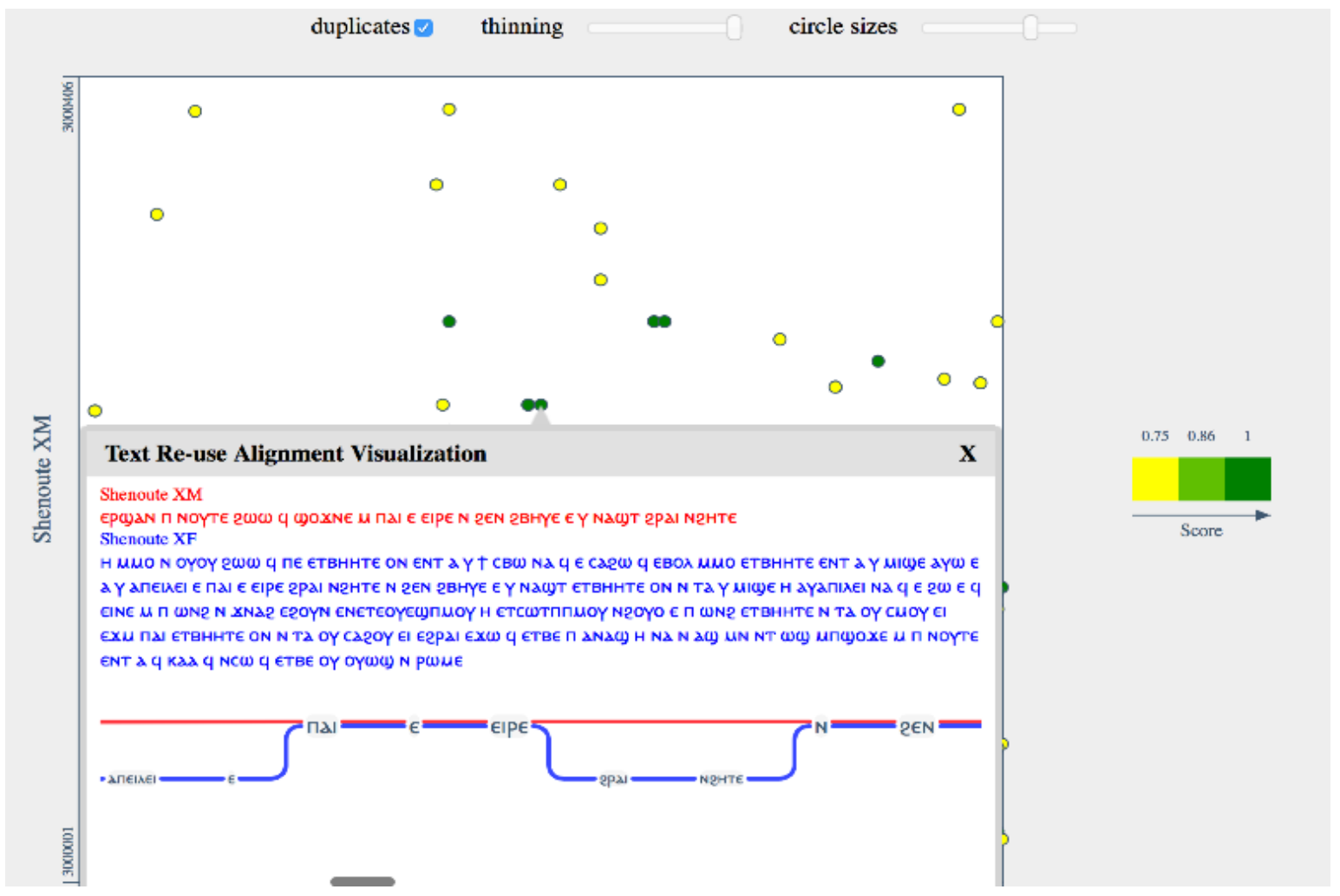

Figure 23: Text reuse alignment by TRAViz. 
Figure 24 shows another visualization of TRAViz. A parallel view of TRACER results in TRAViz, which can facilitate comparison. When the cursor is placed over a pair of paragraphs that are candidates for text reuse, their shared morphs are highlighted in blue. In addition, clicking on a line in the left column inside the visualization graph directs the user to related pairs of text reuse candidates.

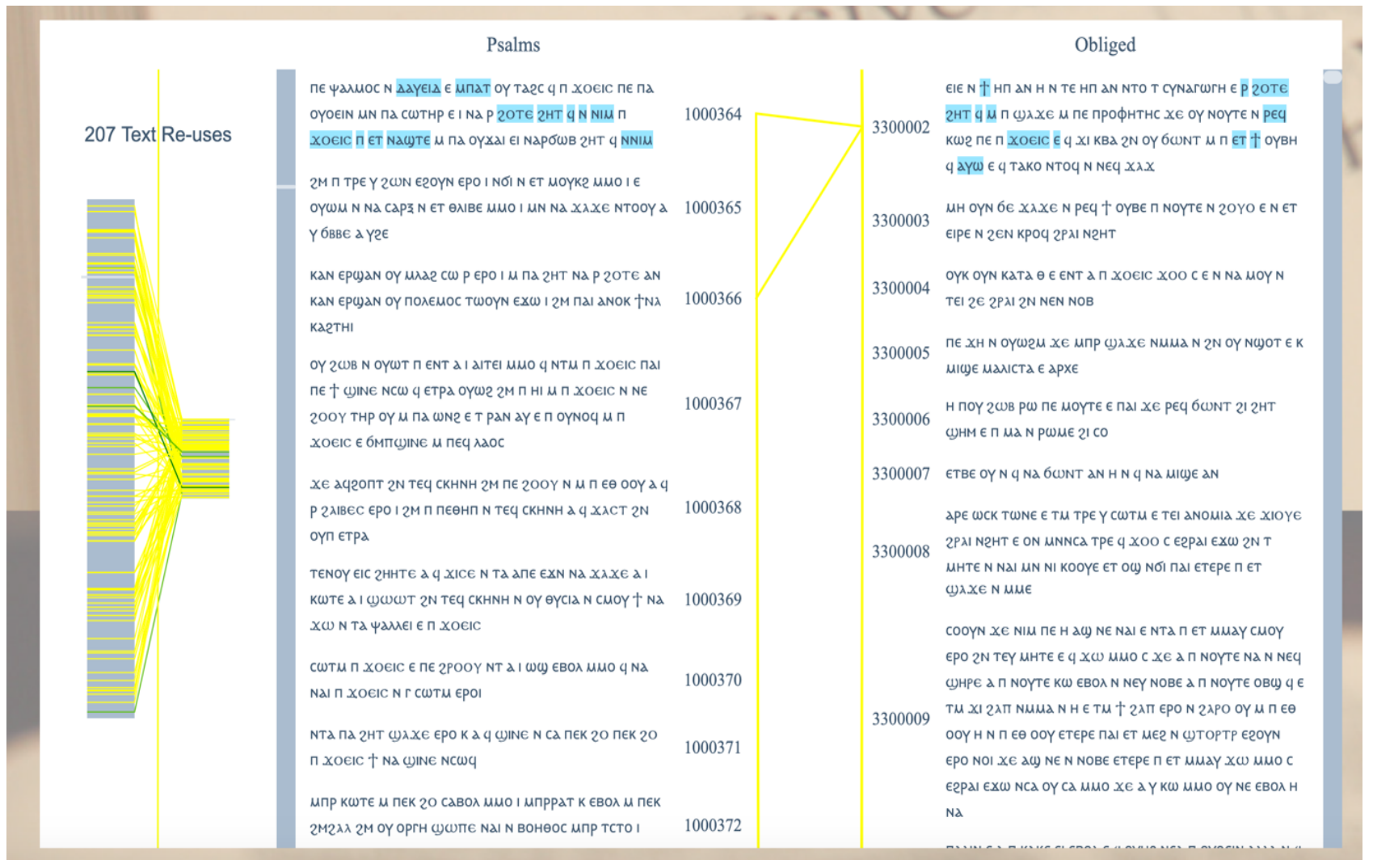

Figure 24: Parallel view of TRAViz.

\subsection{Chapter summary}

Using OCR tools (Subsection 3.2.1.1) and a Unicode converter (Subsection 3.2.1.3.1), the author digitally extracted text from existing editions of Shenoute's Canon 6 and Besa's works. The texts were then compared to digital surrogates of the original manuscripts using CoptOT's VMR and exported 
in the TEI XML format (Subsection 3.2.1.2). The TEI XML files, which contain digital transcriptions with linguistic and philological information, can be reused in other projects. After adding the base text of CoptOT's edition of the Coptic Bible to the corpus (Subsection 3.1.1), the texts were parsed and linguistically tagged using the tokenizer, POS tagger, and syntactic parser tools developed by Coptic SCRIPTORIUM (Subsections 3.1.4 and 3.2.1.3.2). Thereafter, TRACER was run on the parsed and processed corpus with ca. 700 algorithms (Subsections 3.2.2.1-3.2.2.4). Finally, the results of the TRACER processing were visualized by TRAViz (Subsection 3.2.2.6). 


\section{Corpus}

This chapter describes the text corpus that formed the basis of the analysis. The corpus consisted of three sub-corpora: (A) the base text of the Coptic Psalms (cf. Section 4.1), (B) Shenoute's Canon 6 (cf. Section 4.2), and (C) Besa's Letters and Sermons (cf. Section 4.3). The corpus was prepared for analysis through the pre-processing procedure explained in Chapter 3.

\subsection{Coptic Psalms manuscripts}

The first TRACER run was performed on available transcriptions of Coptic OT and NT texts. TRACER found a maximum of 13,835 text reuse candidates between the Sahidic Bible and Besa's works; 3,452 between the Sahidic Bible and MONB.XM of Canon 6; 673 between the Sahidic Bible and MONB.XV; and 4,289 between the Sahidic Bible and MONB.XF. It would have been onerously time-consuming to examine all 28,249 text reuse candidates. Because TRACER cannot automatically analyze them, it was not possible to examine the types and contexts of text reuses in detail.

Thus, the Psalms were chosen as comparison text for three reasons. First, they are one of the most frequently quoted texts in both Shenoute and Besa's works. Second, they are one of the bestpreserved biblical books in Sahidic translation. Psalms manuscripts are the most frequently attested 
among manuscripts of the Sahidic translation of the OT, ${ }^{420}$ and there are no unattested verses in Sahidic. Finally, most audiences and readers of Shenoute's Canons and Besa's works were monks and nuns who were expected to learn all 151 Psalms — or at least most of them—-by heart.

Ugo Zanetti and Hans Quecke indicated that Psalms are used in the liturgy of churches and monasteries in Upper Egypt on a daily basis and sung as parts of hymns or responsories or for meditation. ${ }^{421}$ However, the generally fragmented transmission and preservation of biblical and liturgical manuscripts in Coptic complicate research on their actual use in monasteries. ${ }^{422}$

${ }^{420}$ According to the internal "Inventory List of CoptOT", the Psalms are the most attested of the books contained in the OT. Out of 1871 manuscript entries, the present author has confirmed that there are 556 registered manuscripts contain Psalms by counting the string "Ps" just as registered in the "Manuscript Content Overview" column with the "match cases" setting using the Visual Studio Code software. If an entry contains any types of the Psalm text, the CoptOT team input "Ps" in the "Manuscript Content Overview" column of the entry once.

421 Zanetti 2008: 205; Quecke 1995: 114.

422 Zanetti 2008: 205, "Psalms are found everywhere in the liturgy of Upper Egypt, they are used in any service as constituent parts of hymns, to be sung as responsories or to accompany a meditation. But was the Psalter systematically read in the White Monastery, from beginning to end or in any other way (for example, with prescribed series, such as in the modern Coptic Agbeyya)? As far as I know, there is no mention of that at all.” Quecke 1995: 114: “Coptic liturgy makes use of psalms and parts of psalms in an amount that is quite unique in the Christian East. Much of this (material), which in the meantime has fallen out of use and is preserved only in fragmentary witnesses, is still lying in profound darkness.” 
Although most manuscripts of Psalms and the manuscripts containing Psalms are fragmentary, they can be assumed to be the most frequently read book from the OT in monasteries in Upper Egypt. Therefore, it is unsurprising that Shenoute extensively quoted from and alluded to them. Records on the usage of Psalms exist in various sources, such as monastic letters, sermons, and hagiographical texts. The recitation of the Psalms was practiced in the earliest age of eremitic monasticism in Egypt. For example, Antony repelled demons by singing the Psalms. ${ }^{423}$ Pachomian literature offers an important attestation to the use of Psalms outside the White Monastery Federation. According to the Rule of Pachomius, a novice had to learn 20 psalms, two of the Apostle's epistles, ${ }^{424}$ or a part of another book of Scripture. ${ }^{425}$

${ }^{423}$ According to Brakke 2009b: 19.

${ }^{424}$ Probably Pauline Epistles. Goehring 1986: 228: “[ ...] and the great opening is the word spoken by the apostle in Eph 4.13.” In addition, see Veilleux 1980: 24.

${ }^{425}$ Rule no. 139: Veilleux 1981: 166, "Whoever enters the monastery uninstructed shall be taught first what he must observe; and when, so taught, he has consented to it all, they shall give him 20 Psalms or two of Apostle's epistles, or some other part of the Scripture. And if he is illiterate, he shall go at the first, third and sixth hours to someone who can teach him and who has been appointed for this. He shall stand before him and learn very studiously with all gratitude. Then the fundamentals of a syllable, the verbs, and nouns shall be written for him, and he shall be forced to read, even if he refuses." 
Systematic studies on Sahidic translations of the Psalms have been published by Jürgen Horn, ${ }^{426}$ Peter Nagel, ${ }^{427}$ and Felix Albrecht. ${ }^{428}$ According to Horn, the preserved manuscripts of the Psalms can be divided into four categories: (A) manuscripts that contain only the Psalms (i.e., Psalters), (B) manuscripts used for rituals that partially contain the Psalms, (C) quotations from the Psalms, and (D) occasional uses that contain the partial texts of the Psalms. The following list reproduces Horn's categorization of Psalm attestations (the only one that has come to the author's notice to date): ${ }^{429}$

Group A: Psalter manuscripts

1. Entire: London, Chester Beatty and Michigan, Mesokemic Mudil Psalter

2. Partial: Berlin, Freer

3. Fragmentarily dispersed: White Monastery Psalters

4. Bilingual (Greek-Sahidic) Psalters

Group B: Ritual books ${ }^{430}$

1. Lectionaries ${ }^{431}$

a. Special Case 1: Bilingual lectionaries or pericopes

b. Special Case 2: Small pericope collections for festivals of saints

${ }^{426}$ Horn 2000.

${ }^{427}$ Nagel 2000 and 2016.

${ }^{428}$ Albrecht 2018.

${ }^{429}$ The following list is a summary of the classification by Horn 2000 .

${ }^{430}$ These were used for church services and called ritualia by Horn 2000.

${ }^{431}$ Lectionaria, according to Horn 2000. 
2. Liturgical books ${ }^{432}$
a. Horologion
b. Hermeneiai ${ }^{433}$

3. Auxiliary books in the liturgy
a. Typika
b. Psalm concordances
c. Scalae to the Bible

Group D: Books of occasional use $\mathrm{s}^{435}$

1. Personal use, meditation

${ }^{432}$ Liturgica, according to Horn 2000 . This category is for manuscripts used in liturgical orders.
${ }^{433}$ The Greek term Hermeneiai denotes religious hymns of a particular type, the text of which is a collage of various Psalm texts.

${ }^{434}$ This signifies quotations from the Psalms in the patristic writings written in Coptic. Quotationes, according to Horn 2000.

${ }^{435}$ Occasionalia, according to Horn 2000. 
2. Wall inscriptions, etc.

3. Magical texts

4. Student exercises

The first group, Psalter manuscripts, is divided into three subcategories by preservation status:

(A1) entirely preserved manuscripts, (A2) partially preserved manuscripts, and (A3) fragmentary scattered manuscripts. Horn included two codices under Subcategory A1: the London Psalter and the Chester Beatty and Michigan Psalter. The London Psalter is an unilluminated papyrus manuscript that consists of 156 folios written in unimodular script. In the British Library, it is preserved as "British Library Or. 5000. ${ }^{436}$ It was discovered by an Egyptian local in 1895 along with a codex that includes 10 homilies. Both books were bound in leather. This codex was published by E. A. Wallis Budge $\mathrm{e}^{437}$ with several transcriptional errors. On the other hand, the Chester Beatty and Michigan Psalter has not been published.

In addition to Sahidic Psalters, Horn also mentioned the Mudil Codex, which contains the entire Psalter written in the Oxyrhynchite dialect, or in another term, Mesokemic dialect. It was published by

${ }^{436}$ A diplomatic edition is available at CoptOT website under the siglum sa 2031:

http://coptot.manuscriptroom.com/manuscript-workspace/?docID=622031, last accessed on November 9, 2021. The identification numbers of this codex are as follows: paths.manuscripts.21 in PAThs, TM 108024 in Trismegistos, 108024 in LDAB, sa 2031 in CoptOT, and sa 31 in Biblia Coptica by Schüssler, CMCL.AV in CMCL, and sa 2031 in LCBM. It was once labeled P. Lond. Copt. 1940 descr. in Crum 1905, a catalogue of Coptic manuscripts held at the British Museum at the beginning of the 20th century.

${ }^{437}$ Budge 1898. In addition, see Prince 1902. 
Gawdat Gabra. ${ }^{438}$ Although Horn did not mention it, ${ }^{439}$ the Egyptology section of the University of Pennsylvania Museum in Philadelphia holds an unpublished Psalter. ${ }^{440}$ New Psalm fragments have been discovered recently, including a part of a Psalter in the Lycopolitan dialect preserved in the Utrecht University Library Special Collections ${ }^{441}$ and several Sahidic Psalm fragments, which are currently being gathered and edited by CoptOT. ${ }^{442}$

Under Subcategory A2, Horn included two codices: the Berlin Psalter edited by Alfred Rahlfs ${ }^{443}$ and the Freer Psalter, which is preserved in the Freer Collection in Washington, D.C. and was first published by William $\mathrm{H}$. Worrell. ${ }^{444}$ These codices contain a very large number of lacunae.

Under Subcategory A3, Horn mentioned the fragmentary and dispersed Psalters from the White Monastery, which are mainly kept at the Bibliothèque Nationale de France in Paris, the Österreichische Nationalbibliothek in Vienna and other collections. This study mainly uses the London Psalter- edited

${ }^{438}$ See Gabra 1995; see also Emmenegger 2007.

${ }^{439}$ Horn 2000.

${ }^{440}$ See Kraft 1976.

${ }^{441}$ See B4.15.1-11 (35) of its Coptic papyrus collection: https://www.uu.nl/en/utrecht-universitylibrary-special-collections/collections/manuscripts/other-medieval-manuscripts/collection-of-coptic-manuscripts, last accessed on November 8, 2021.

${ }^{442}$ For details on CoptOT, see Subsection 3.1.1.

${ }^{443}$ Rahlfs 1904.

${ }^{444}$ Worrell 1923. 
and revised by Diliana Atanassova, Suzana Hodak, and Chrysi Kotsifou-in CoptOT's VMR. ${ }^{445}$ However, the edited volumes of the Berlin Psalter by Rahlfs and the Freer Psalter by Worrell were also compared when there was a difference between the London Psalter and Shenoute's quotations from the Psalms. Due to their fragmentary state and dispersal, the Psalters from the White Monastery have not yet been reconstructed and critically edited. Since they were produced in Shenoute's own monastery, they should in theory be the best basis of comparison between Shenoute's text reuses and the Psalm text.

Category B (Ritualia) encompasses codices and manuscripts mainly designed for liturgical purposes. Horn divided Category B into three subcategories: (B1) Lectionaria, (B2) liturgical orders, and (B3) auxiliary books in liturgies. Horn presented two special cases for Subcategory B1: (i) bilingual lectionaries or pericopes and (ii) small pericope collections for festivals of saints.

Nagel studied the bilingual Psalms in his work, ${ }^{446}$ in which he categorized the bilingual Coptic Psalm texts into three groups: (A) text manuscripts, (B) lectionaries, and (C) liturgical manuscripts. Moreover, according to Felix Albrecht's recent paper on bilingual Psalm manuscripts, he presented four Graeco-Coptic bilingual Psalters: ${ }^{447}$ (i) a fragmentary papyrus codex called the bilingual Psalter, ${ }^{448}$ of which 25 sheets are preserved at the Österreichische Nationalbibliothek; (ii) fifth to sixth-century

\footnotetext{
${ }^{445}$ The base text used in this study was downloaded from CoptOT on July 4, 2018.

${ }^{446}$ Nagel 1984a: 236.

${ }^{447}$ These are text manuscripts that exclusively contain the entire Psalms. See Albrecht 2018.

${ }^{448}$ LCBM sa 2022, sa 72 according to Schüssler's Biblia Coptica, and Ra 1220 according to Rahlfs and
} Frankel 2004. 
bilingual Psalms from the White Monastery, ${ }^{449}$ fragments of which are preserved in Paris, Vienna, Cairo, London, and New York, (iii) a 10th to 11th-century bilingual lectionary of the Psalms and Gospels preserved in Paris, Vienna, London, and Cairo, ${ }^{450}$ and (iv) the sixth-century bilingual Odes liturgical manuscript. $^{451}$

Subcategory B2 is the Liturgica. Horn further divided B2 into B2a (Horologion) and B2b (Hermeneiai). Psalms played an important role in the monastic Horologion, which has been extensively studied by Hans Quecke. ${ }^{452}$ The same is true of Hermeneiai. Subcategory B3 consists of auxiliary books used in liturgies. They are further divided into B3a (Typika), B3b (Psalm concordances), and B3c (Scalae to the Bible). ${ }^{453}$ Typika are lists of incipits from texts of liturgical readings and hymns $\mathrm{s}^{454}$ arranged according to church year. Often, these include Psalm texts. B3b. Psalm concordances are collections of stichoi. ${ }^{455}$ They were tools for cantors who recited at liturgies. According to Horn, these concordances are preserved only in fragments.

${ }^{449}$ LCBM sa 2036, Biblia Coptica sa 91, Ra 2015.

${ }^{450}$ In LCBM, this codex is sa 336L.

${ }^{451}$ LCBM sa 289, Biblia Coptica sa 16lit, and Ra 2036.

${ }^{452}$ See Quecke 1970

${ }^{453}$ The Latin term Scalae refers to multilingual glossaries.

${ }^{454}$ For Typika from the White Monastery, see Atanassova 2010a and 2010b.

${ }^{455}$ Stichoi means keywords of the Psalms. 
Group C consists of quotations., which Horn divided into two subcategories: (C1) citations in exegetical works and (C2) citations in other Coptic literature. He argued that Subcategory $\mathrm{C} 1$ is very small, as few works of Coptic exegetical literature used the theme of Psalms. By contrast, Subcategory C2 is abundantly represented in the Coptic literature. It was further divided into (C2a) Pachomian literature, (C2b) Shenoutean literature, ${ }^{456}$ and (C2c) other homilies. Now, other abbots from the White Monastery, such as Apa John, can be added under C2b. ${ }^{457}$

Research on $\mathrm{C} 2 \mathrm{~b}$ has been conducted by Timbie ${ }^{458}$ and Behlmer. ${ }^{459}$ Timbie also researched and published papers on quotations from Solomonic books such as Proverbs, Qohelet, Wisdom of Solomon, and Song of Songs in Pachomian and Shenoutean literature. Anne Boud'hors provided a general assessment of the importance of biblical quotations by Shenoute and Besa for biblical studies. ${ }^{460}$

${ }^{456}$ Horn 2000 included writings by Besa and Pseudo-Shenoute as well as Shenoute under Shenoutean literature.

${ }^{457}$ Diliana Atanassova edited the texts of manuscripts for Apa John's works. They are available at http://coptot.manuscriptroom.com/web/apa-johannes, last accessed on January 1, 2020.

${ }^{458}$ See Timbie 2011 and 2013.

${ }^{459}$ See Behlmer 2008 and 2017. In addition, Behlmer discussed the use of biblical language in Besa's rhetoric in Behlmer 2009 and 2016 and the use of Psalms by Shenoute in He Who Sits Upon His Throne in Behlmer 2017.

${ }^{460}$ Boud'hors 2017, discussed the biblical quotations in Coptic fathers. 
Finally, Category D comprises occasional writings, including texts from Psalms. Horn divided Group D in four subcategories: (D1) text excerpts for personal use, (D2) text snippets for the edification of a community, (D3) Psalm excerpts for use in magical texts, ${ }^{461}$ and (D4) student exercises. Writings in Subcategory D1 were mainly used for private meditations and prayers written on ostraca and papyri. Writings in Subcategory D2 were mainly preserved on the walls of monasteries and churches. In addition, the Psalms were important in magical texts in Subcategory D3 and were often used for magic spells. Finally, writings in Subcategory D4 were often used on ostraca as school exercises. ${ }^{462}$

The Psalms are one of the most frequently quoted biblical texts in Shenoute's works. For example, according to Boud'hors' data on quotations in MONB.XO, Psalms were reused 32 times among 464 intertexts by Shenoute. ${ }^{463}$ Of all OT books used as quotations sources, this number was the highest. ${ }^{464}$ This proportion is the same in Canon 6. Moreover, Behlmer's latest study on the use of

${ }^{461}$ Sanzo 2014 discussed the apotropaic use of the Psalms in Late Antique Egypt.

${ }^{462}$ Cromwell 2013 and 2015 focused on writing exercises.

${ }^{463}$ CoptOT calculated the frequency, according to Boud'hors 2017. The data is accessible on one of its portals, https://docs.google.com/spreadsheets/d/1_EmmZISkelMOF1NcyAtqCCfFghjGHshwazPHe2sPAE/edit\#gid=1186586434, last accessed on October 1, 2021.

${ }^{464}$ According to CoptOT, the most intertexts were found in the Psalms (43 cases), and the second-most intertexts were found in the Book of Jeremiah ( 38 cases). Of all the biblical books, the Gospel of Matthew from the NT contained the most intertexts (51 cases), the Psalms, contained the second-most intertexts, and the Book of Jeremiah contained the third-most intertexts. 
Psalms in the first work of Canon 6, He Who Sits Upon His Throne, demonstrates that Shenoute recontextualized quotations from the Psalms by weaving the voice of the persecuted righteous into his own discourse in "a skillful integration of the biblical text into the argument."

For the purposes of this study, the codex "British Library Or. 5000" (sa 2031) was used as the main source of the Psalms text, as it is the most easily accessible and complete Psalter. Because this codex was published by Budge, it is sometimes informally called the "Budge Psalter." During Budge's tenure, the British Library was not an independent organization, and the Psalter was preserved as "Ms. Or. 5000" at the British Museum. It contains 156 folios that measure approximately $30 \mathrm{~cm}$ in height by $21 \mathrm{~cm}$ in width. ${ }^{466}$ According to Schüssler, ${ }^{467}$ the Psalter's estimated date of production is the sixth to seventh century.

${ }^{465}$ See Behlmer 2017: 327.

${ }^{466}$ See the metadata of sa 2031 (Or. 5000) in CoptOT’s VMR, http://coptot.manuscriptroom.com/manuscript-workspace/?docID=622031, last accessed October 1, 2021; see also Budge 1898: IX.

${ }^{467}$ Budge 1898: XII, “The shape and size and general appearance of the pages of the older portion in every respect suggest that the volume cannot have been written after the end of the VIIth century of our era, but it seems to me that the date when it was written lies nearer the beginning than the end of that century; it may, indeed, quite well be placed at the end of the VIth century." In addition, see Schüssler 1996: 43-44 and Crum 1905: 940 descr. 


\subsection{Shenoute's Canon 6}

Like the works of many other patristic authors in Early Christianity, Shenoute's works abound with quotations from and allusions to the Holy Scriptures. As the present study and other recent research show, his interpretation of the Scripture was adapted to his contemporary situation. A prolific author, Shenoute composed diverse works in his native language, Coptic. The distinction between Canons and Discourses (Logoi) is already being made by the Vienna Incipit List, ${ }^{468}$ which Emmel used as a major source of reconstruction for Shenoute's literary corpus. ${ }^{469}$

The Life of Shenoute, a compilation of encomiae filled with hagiographical episodes attributed to Besa, ${ }^{470}$ boasts of the monastic federation's massive membership under Shenoute's tenure. This was detailed in the expansive Arabic version, which was compiled well after Shenoute and his immediate

${ }^{468}$ For the distinction between Canons and Discourses, see Subsection 1.1.2.

${ }^{469}$ Emmel 2004: 71 stated, "What is referred to as the 'Vienna incipit list,' or simply the 'Vienna list,' is a single leaf from a parchment codex from the White Monastery [...] containing the last two thirds of a list of ninety-one numbered incipits of works of Shenoute; see plates 1 and 2 on pp. 72-73. The significance of this list for the reconstruction of Shenoute's literary corpus, specifically the Discourses, the sentence should be quoted fully [...].” The shelf number of the Vienna Incipit List is the Österreichische Nationalbibliothek, K 9634.

${ }^{470}$ See Lubomierski 2007a, 2007b, and 2008. Also see Subsection 1.1.1. 
successors' lifetime. ${ }^{471}$ This information about the size of the monastic population was not mentioned in the Bohairic version of the Life of Shenoute. ${ }^{472}$ Although the Life's historical veracity is highly dubious, there is a consensus that Shenoute supervised a considerable number of monks and nuns.

Shenoute lived in a cave outside his monastery federation. To direct the latter and uphold discipline from his refuge, he wrote numerous letters. In Shenoute's lifetime, his disciples started collecting these writings into nine volumes of Canons and eight volumes of Discourses, as reconstructed by Emmel. ${ }^{473}$ Emmel estimated that around one-sixth of Shenoute's literary legacy has been

${ }^{471}$ An English translation of the Arabic Life was published by a team of the Coptic Orthodox Church in 2015 under the name of the Arabic version of Besa following the tradition of the Coptic Orthodox Church (see Wissa 2015).

${ }^{472}$ The Bohairic version was translated by Bell in 1983 (Bell 1983). In the introduction, he described Shenoute as a fearful and gruesome tyrant and ascribed the authorship of the Life to Besa, an unexceptional monastic leader. Both views can no longer be upheld in light of more recent scholarship. For the Bohairic text, see Leipoldt and Crum 1906; for the Latin translation of Leipoldt and Crum 1906, see Wiesmann 1951. Lubomierski 2007a represents the most comprehensive philological study of manuscripts and translations of the Life of Shenoute.

${ }^{473}$ For the distinction between Canons and Discourses, see Subsection 1.1.2. Emmel 2004c: 599 mentioned that it was Shenoute who ordered the compilation of Canon 9: "Volume 9 of Shenoute's Canons survives in seven manuscripts, one of them aberrant in some way yet to be clarified (BV). Codex DF is identified as a manuscript of Canon 9 by a superscript title, "By Shenoute, a gift (xapıc), 9." This title is followed by a long 
preserved, ${ }^{474}$ which may have originally amounted to as many as 25,000 pages of Coptic text. Although much of the Coptic manuscript tradition has been lost or seems to have been done deliberately mutilated, Shenoute was arguably the most prolific Coptic writer of his time and perhaps of all time.

Shenoute's works were almost exclusively preserved in his monastery's library. Since the 18th century, fragments from the library have been dispersed throughout Europe ${ }^{475}$ and, in part, North

heading (copied also at the beginning of the section of XL that is devoted to Canon 9) that introduces the volume as a whole and shows that it was Shenoute who masterminded its compilation (DF 1:i.l-14, $\mathrm{XL}$ frg. $2 \mathrm{~b}^{\mathrm{r}}$ :i.l-13):

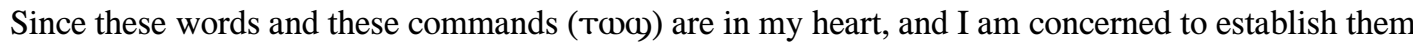
before I depart (дпоАнмеІ), and since I had written them on tablets (пıмакıс) when we came to the places (топос) and we copied them onto these papyrus sheets (хартнс) during all those distressing days before Lent (тессардкостн), these great disturbances and the multitude of all this tearful distress that has happened to this miserable man at the hands of the pagans and the perpetrators of violence and him who goads them against us, Satan, have not been able to keep us from doing everything we want."

${ }^{474}$ Emmel 2004c: 52-53 stated, "On the basis of the reconstruction that has been achieved thus far, I estimate that the extant White Monastery codexes of Shenoute's works contained at least about 12,500 leaves (25,000 pages), of which somewhat less than 2,000 leaves survive (4,000 pages). Many of these leaves, however, are but fragments of leaves."

${ }^{475}$ For more on the dissemination process for the pages of the White Monastery manuscripts, see Louis 2008 and Suciu and Orlandi 2016. In particular, Louis 2008 tried to reconstruct the history of the early modern dissemination of manuscripts from the library of the White Monastery to Europe and North America. 
America. In 1892, Gaston Maspero described the storeroom of the White Monastery, where he found the remaining manuscripts. ${ }^{476} \mathrm{~A}$ considerable portion of the manuscripts (ca. 4,000 leaves and fragments) was brought to the Bibliothèque Nationale de France in Paris, but many fragments ended up in other collections.

The codices containing Shenoute's works were thoroughly investigated and reconstructed by Emmel based on the Vienna Incipit List ${ }^{477}$ and through projects such as CMCL ${ }^{478}$ and scholars such as Tito Orlandi. Before Emmel's reconstruction, some scholars—most prominently, Amélineau ${ }^{479}$ and Leipoldt ${ }^{480}$ — had identified texts authored by Shenoute mainly based on their style and content, which led to incorrect attributions. Thus, they sometimes misattributed texts or incorrectly edited the texts of others as Shenoute's. ${ }^{481}$

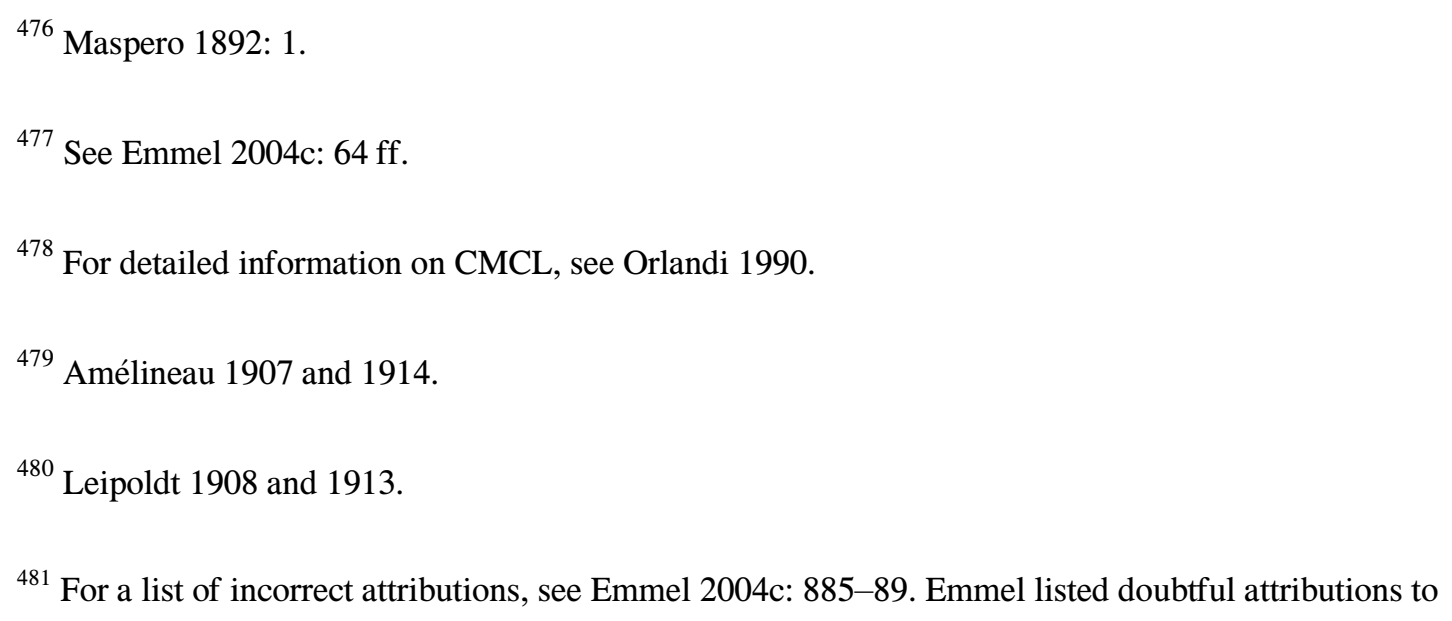


Based on Emmel's reconstruction, a complete edition is currently being prepared by an international team led by him. ${ }^{482}$ So far, only an edition of MONB.XO, which contains Canon 8 , which is represented by, in addition to MONB.XO, by codices MONB.FL, MONB.XX, MONB.ZR, MONB.YE, and MONB.XL (florilegium), was published by Boud'hors. ${ }^{483}$ Various parts of Discourses 4 and 5 have been translated by David Brakke and Andrew Crislip. ${ }^{484}$ In his Ph.D. thesis, Mark Moussa produced an edition of I Have Been Reading the Holy Gospels, which constitutes Work 1 in Discourses 8. ${ }^{485} \mathrm{~A}$ translation of The Lord Thundered was published by Timbie and Jason Zaborowski. ${ }^{486}$ Moreover, the rules extracted from Shenoute's works were published by Bentley Layton. ${ }^{487}$ Finally, Coptic SCRIPTORIUM digitally published various Shenoutean texts in XML format with visualizations by ANNIS: Abraham Our Father, Acephalous Work 22, Because of You Too O Prince of Evil, God Says Through Those Who Are His, I See Your Eagerness, In the Night, Not Because a Fox Barks, Some

${ }^{482}$ See Crislip 2016: 335.

${ }^{483}$ Boud'hors 2013 contains transcriptions, translations, information about intertextuality, and photos of the manuscripts of MONB.XO.

${ }^{484}$ Brakke and Crislip 2015 gave a brilliant introduction to the life and texts of Shenoute and the White Monastery Federation, followed by translations of selected texts from Discourses 4 and 5.

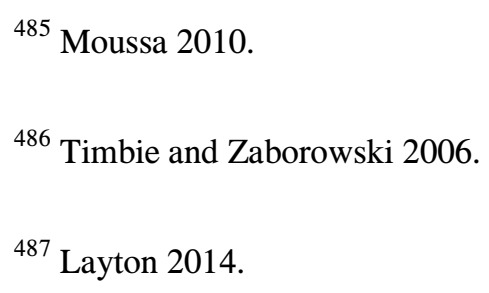


Kinds of People Sift Dirt, Unknown Work 5-1, and Whoever Seeks God Will Find. ${ }^{488}$ These Coptic SCRIPTORIUM texts were made philologically and linguistically searchable with the ANNIS Query Language.

${ }^{488}$ The following list contains the citation information of these corpora:

- “Abraham Our Father,” Coptic SCRIPTORIUM, CTS: urn:cts:copticLit:shenoute.abraham, http://data.copticscriptorium.org/texts/abraham_our_father, last accessed on October 8, 2021;

- “Acephalous Work 22,” Coptic SCRIPTORIUM, CTS: urn:cts:copticLit:shenoute.a22, http://data.copticscriptorium.org/texts/acephalous_work_22, last accessed on October 8, 2021;

- "Because of You Too O Prince of Evil," Coptic SCRIPTORIUM, CTS: urn:cts:copticLit:shenoute.prince, http://data.copticscriptorium.org/texts/shenouteprince, last accessed on October 8, 2021;

- “God Says Through Those Who Are His,” Coptic SCRIPTORIUM, CTS: urn:cts:copticLit:shenoute.those, http://data.copticscriptorium.org/texts/shenoutethose, last accessed on October 8, 2021;

- "I See Your Eagerness,” Coptic SCRIPTORIUM, CTS: urn:cts:copticLit:shenoute.eagerness, http://data.copticscriptorium.org/texts/eagernesss, last accessed on October 8, 2021;

- "In the Night," Coptic SCRIPTORIUM, CTS: urn:cts:copticLit:shenoute.night, last accessed on October 8, 2021; 
This study solely focuses on Canon 6, which, according to Emmel, originally included at least five works. However, it likely contained more because of its numerous and extensive lacunae. Canon 6 is transmitted in six codices: MONB.XM, MONB.XF, MONB.XL, MONB.XV, MONB.YJ, and

- “Not Because a Fox Barks,” Coptic SCRIPTORIUM, CTS: urn:cts:copticLit:shenoute.fox, http://data.copticscriptorium.org/texts/not_because_a_fox_barks, last accessed on October 8, 2021;

- "Some Kinds of People Sift Dirt,” CTS: urn:cts:copticLit:shenoute.dirt, http://data.copticscriptorium.org/texts/shenouteunknown5_1, last accessed on October 8, 2021;

- “Unknown Work 5-1,” Coptic SCRIPTORIUM, CTS:

urn:cts:copticLit:shenoute.unknown5_1, http://data.copticscriptorium.org/texts/shenouteunknown5_1, last accessed on October 8, 2021; and

- "Whoever Seeks God Will Find," Coptic SCRIPTORIUM, CTS: urn:cts:copticLit:shenoute.seeks, http://data.copticscriptorium.org/texts/shenouteseeks, last accessed on October 8, 2021.

"CTS" stands for the Canonical Text Service, which identifies a work from antiquity and Late Antiquity through a universal resource name (URN). See http://cts.informatik.unileipzig.de/Canonical_Text_Service.html, last accessed on October 8' 2021. For the details of CTS, see Tiepmar and Heyer 2017. 
MONB.YK. The total number of available pages is approximately $325{ }^{489}$ Table 2 shows the percentage of preserved pages in the six codices located at each modern institution that holds parts of Canon 6 . The darker a cell's color, the higher the percentage of pages preserved at that institution.

\begin{tabular}{|c|c|c|c|c|}
\hline City & Country & Institution & $\begin{array}{l}\text { Number of } \\
\text { pages }\end{array}$ & Percentage \\
\hline Cairo & Egypt & Coptic Museum $^{490}$ & 12 & $3 \%^{491}$ \\
\hline Leiden & Netherlands & Rijksmuseum van Oudheden & 2 & $1 \%{ }^{492}$ \\
\hline London & United Kingdom & British Library & 2 & $1 \%$ \\
\hline Naples & Italy & Biblioteca Nazionale di Napoli ${ }^{493}$ & 92 & $26 \%$ \\
\hline $\begin{array}{l}\text { New } \\
\text { Haven }\end{array}$ & United States & $\begin{array}{l}\text { Beinecke Rare Book and Manuscript Library, Yale } \\
\text { University }\end{array}$ & 2 & $1 \%$ \\
\hline Oxford & United Kingdom & Bodleian Library & 8 & $2 \%$ \\
\hline Paris & France & Bibliothèque Nationale de France & 220 & $61 \%$ \\
\hline Vienna & Austria & Österreichische Nationalbibliothek & 20 & $6 \%$ \\
\hline
\end{tabular}

Table 2: Percentage of pages from Shenoute's Canon 6 held at modern institutions.

${ }^{489}$ See Emmel 2004c: 553.

${ }^{490}$ In Arabic, Mathaf al-Qibțī. The Coptic Museum is located in Old Cairo and was established by

Marcus Simaika Pasha in 1908. It is currently one of the largest institutions that preserves Coptic art and manuscripts.

${ }^{491}$ All numbers in this study are rounded down if the number after the decimal is between $.0-.4$ and rounded up if the number below after the decimal is between .5-.9. However, if the number before the decimal is 0, I keep two places after the decimal.

492 This figure was approximately $0.55 \%$ before being rounded down, which is the same percentage of pages preserved at the British Library and the Beinecke Rare Book and Manuscript Library.

${ }^{493}$ Also known as the Biblioteca Nazionale Vittorio Emanuele III (see Buzi 2009). 
The preserved pages of Canon 6 are dispersed in Egypt and Europe; 96\% are in Europe today.

This is a result of European institutions and collectors' purchases of individual pages and sometimes even fragments of pages since the eighteenth century, mainly through dealers. For example, the pages currently held at the Biblioteca Nazionale were purchased by Cardinal Stefano Borgia (not directly by Borgia himself but by Simone Assemani) from a dealer in Cairo in 1778. The collection at the Bibliothèque Nationale de France in Paris was mainly acquired or purchased by Gaston Maspero, Auguste Frenay, and Émile Amélineau with the assistance of Marius Tano, a dealer in Cairo; Xavier Charmes, who was the Minister of Public Instruction in France; Eugène Grébaut, director of the Institut Français d'Archéologie Orientale; and Émile Guimet.

There are extensive parallel passages between MONB.XF, MONB.XM, and MONB.XV. Thus, Emmel argued that these three codices were copies of a single volume. MONB.YJ was hypothetically a volume of Canon 6. On the other hand, Emmel assumed that MONB.YK was not a complete manuscript of Canon 6. The last codex, MONB.XL, is a florilegium. The pages of MONB.XF, MONB.XM, MONB.XV, MONB.YJ, MONB.YK, and MONB.XL are scattered in eight institutions across the world. According to Emmel,

[...] it appears that at least Canons 1, 2, 6, 7, 8, and 3 can be seen to present the works contained in them in a chronological sequence, in this order. If this appearance is correct, then the numbering of the Canons as we have them is probably secondary. And since the florilegium Sinuthianum, which is based 
on the Canons, follows this numbering, it would seem that it was not Shenoute who compiled the florilegium, but someone from a later period. ${ }^{494}$

From MONB.YW 209: i.15-24, which includes a passage declaring that the work is a copy of a text written on a xapTHc ("papyrus sheet"), Emmel deduced that Shenoute's works, or at least Canon 1 , were first written on papyrus.

Among the six codices of Canon 6, MONB.XM is the best-preserved. Table 3 shows the pages of each codex as a percentage of the total number of pages in Canon 6. There are very few preserved pages for MONB.YK and MONB.XL, whereas MONB.XF, MONB.XM, MONB.XV, and MONB.YJ collectively represent $98.3 \%$ of Canon 6 .

\begin{tabular}{|l|l|l|l|l|l|l|}
\hline MONB & $X F$ & $X M$ & $X V$ & $Y J$ & $Y K$ & $X L$ \\
\hline $\begin{array}{l}\text { Number of } \\
\text { pages }\end{array}$ & 114 & 135 & 34 & 20 & 1 & 4 \\
\hline Percentage & $37 \%$ & $44 \%$ & $11 \%$ & $7 \%$ & $0.3 \%$ & $1 \%$ \\
\hline
\end{tabular}

Table 3: Number of pages in each codex as a percentage of total pages in Canon 6.

Incipits can be used by modern scholars instead of titles to identify a work. However, this practice was already used in antiquity. For Shenoute's works, the so-called "Vienna Incipit List,"495 which contains the last two-thirds of originally 91 incipits, ${ }^{496}$ played an important role in Emmel's reconstruction of Shenoute's literary corpus. These following five incipits appear in the preserved parts of Canon 6:

\footnotetext{
${ }^{494}$ Emmel 2004c: 556. Cf. also Behlmer 2008: 3.

${ }^{495}$ Vienna, Österreichische Nationalbibliothek K 9634.

${ }^{496}$ Emmel 2004c: 71-75.
} 
1. He Who Sits upon His Throne (пєтәмоос гпєчөромос)

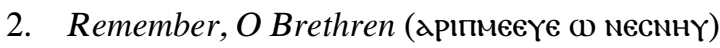

3. Is It Not Written (мн мчснг aN)

4. Then I Am Not Obliged (ë̈ен十н aN)

5. People Have Not Understood (мпєромє еіме)

Behlmer summarized topics in Canon 6 as follows: ${ }^{497}$

1. Accusations against Shenoute of excessive force and his defense; He Who Sits upon His Throne; Remember, O Brethren; Is It Not Written,

2. Shenoute's illness; Remember, O Brethren; Is It Not Written; Then I Am Not Obliged,

3. Affairs of the female community; He Who Sits upon His Throne; Then I Am Not Obliged; People Have Not Understood,

4. Monastic rules.

In He Who Sits Upon His Throne, Shenoute accuses monks of being evil and disobedient and he prays that God will punish them. In Remember O Brethren, Shenoute admonishes the monastic community. In Is It Not Written, Shenoute speaks about his illness and monastic discipline. In Then I Am Not Obliged, he focuses on his own sins and those of his subordinates. The latter is the longest preserved work in Canon 6 and seems to have been a letter sent to Tapolle and other women. ${ }^{498}$

\footnotetext{
${ }^{497}$ Behlmer 2008: 2-3.

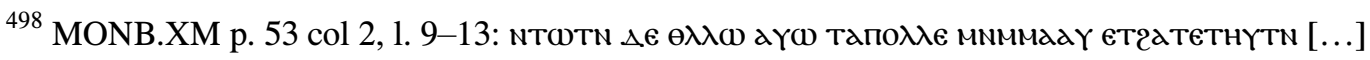

("You, however, female elder and Tapolle, with the mothers who are with you, [...].") See also Krawiec 2002: 43-46. 
Behlmer ${ }^{499}$ suggested that most of the works concerned internal opposition against Shenoute in the monastic federation.

Table 4 shows the percentage of preserved pages in Canon 6 grouped by work.

\begin{tabular}{|c|c|c|c|c|c|}
\hline $\begin{array}{l}\text { MONB.XF, } \\
\text { MONB.XM, } \\
\text { MONB.XV, } \\
\text { MONB.YJ, } \\
\text { MONB.YK, XL }\end{array}$ & $\begin{array}{ll}\text { He Who Sits } \\
\text { Upon } & \text { His } \\
\text { Throne } & \end{array}$ & $\begin{array}{l}\text { Remember, } O \\
\text { Brethren }\end{array}$ & $\begin{array}{l}I s \quad I t \\
\text { Written }\end{array}$ & $\begin{array}{l}\text { Then Am I Not } \\
\text { Obliged }\end{array}$ & $\begin{array}{l}\text { People Have } \\
\text { Not Understood }\end{array}$ \\
\hline Pages & 48 & 22 & 89 & 130 & 9 \\
\hline Percentage & $16 \%$ & $7 \%$ & $29 \%$ & $45 \%$ & $3 \%$ \\
\hline
\end{tabular}

Table 4: Number of pages in each work as a percentage of total pages in Canon 6.

It does not separately account for the overlap caused by parallel portions of texts in multiple codices or lacunae and missing pages. Of the works of Canon 6, Then Am I Not Obliged represents 45\% of total pages. Moreover, as identified by Layton, Canon 6 contains 38 passages that can be classified as monastic rules. ${ }^{500}$ In the following subsections, the manuscripts that attest Canon 6 are described in more detail.

${ }^{499}$ See Behlmer 2008:7.

${ }^{500}$ Layton 2014: 201-17, rule nos. 265-302. 


\subsubsection{MONB.XF}

MONB.XF is the only codex with a preserved first page. MONB.XF's PAThs ID is Coptic Literary Manuscript (CLM) $607 .{ }^{501}$ It features two columns of 30 lines on average, and the script is unimodular. The pages have traces of ruling. The ekthesis is relatively small, usually extending over no more than two lines. For information on text parallels in MONB.XF, MONB.XM, MONB.XV, MONB.YJ, MONB.YK, and MONB.XL, see the collation table by Emmel. ${ }^{502}$ Table 5 lists the pages of MONB.XF and their institution, contents, and associated publications.

\begin{tabular}{|c|c|c|c|c|}
\hline Pages & Institution & Shelf no. & Contents & Publications \\
\hline $1-28^{503}$ & $\begin{array}{l}\text { Bibliothèque Nationale de } \\
\text { France, Paris }\end{array}$ & $\begin{array}{l}\text { Copte } 130^{1} \\
\text { ff. } 24-34\end{array}$ & He Who Sits Upon His Throne & $\begin{array}{l}\text { Amélineau } \\
\text { 1914: } 286- \\
308,552\end{array}$ \\
\hline $29-46$ & \multicolumn{4}{|l|}{ Missing } \\
\hline \multirow[b]{2}{*}{$47-48$} & British Library, London & Or. 6954 & \multirow[b]{2}{*}{ Remember, O Brethren } & $\begin{array}{l}\text { Unpublished } \\
504\end{array}$ \\
\hline & Coptic Museum, Cairo & $\begin{array}{l}\text { Inventory } \\
\text { number } \\
\text { unknown }\end{array}$ & & Unpublished \\
\hline $77-78$ & $\begin{array}{l}\text { Bibliothèque Nationale de } \\
\text { France, Paris }\end{array}$ & $\begin{array}{l}\text { Copte } 130^{2} \mathrm{f} . \\
116\end{array}$ & Remember, O Brethren & Unpublished \\
\hline $79-86$ & \multicolumn{4}{|l|}{ Missing } \\
\hline
\end{tabular}

${ }^{501}$ See “paths.manuscripts.607,” PAThs, https://atlas.paths-erc.eu/manuscripts/607, last accessed on October 8, 2021.

\footnotetext{
${ }^{502}$ Emmel 2004: 731-44.

${ }^{503}$ It is likely that the scribe accidentally skipped p. 6. Therefore, p. 5 and p. 7 are on the same folio.

${ }^{504}$ Layton 1987: 181 has an excerpt from this folio.
} 


\begin{tabular}{|c|c|c|c|c|}
\hline $87-88$ & $\begin{array}{l}\text { Bibliothèque Nationale de } \\
\text { France, Paris }\end{array}$ & $\begin{array}{l}\text { Copte } 130^{5} \mathrm{f} . \\
99\end{array}$ & Remember, O Brethren & $\begin{array}{l}\text { Unpublished } \\
505\end{array}$ \\
\hline $89-154$ & \multicolumn{4}{|l|}{ Missing } \\
\hline $155-56$ & Coptic Museum, Cairo & C.G.9268 & Is It Not Written & $\begin{array}{l}\text { Munier 1916: } \\
111-172^{506}\end{array}$ \\
\hline $157-78$ & \multicolumn{4}{|l|}{ Missing } \\
\hline $179-92^{507}$ & $\begin{array}{l}\text { Bibliothèque Nationale de } \\
\text { France, Paris }\end{array}$ & $\begin{array}{l}\text { Copte } 130^{5} \mathrm{f} . \\
131\end{array}$ & Is It Not Written & $\begin{array}{l}\text { Leipoldt 1906: } \\
192-3^{508}\end{array}$ \\
\hline 193-202 & \multicolumn{4}{|l|}{ Missing } \\
\hline $203-68$ & $\begin{array}{l}\text { Biblioteca Nazionale di } \\
\text { Napoli, Naples }\end{array}$ & IB3 ff. 1-31 & $\begin{array}{l}\text { Is It Not Written ends and Then } \\
\text { Am I Not Obliged starts on p. } \\
256\end{array}$ & $\begin{array}{l}\text { Am é lineau } \\
\text { 1907: } 37- \\
84^{509}\end{array}$ \\
\hline $269-70$ & \multicolumn{4}{|l|}{ Missing } \\
\hline $271-78$ & $\begin{array}{l}\text { Biblioteca Nazionale di } \\
\text { Napoli, Naples }\end{array}$ & $\begin{array}{l}\text { IB3 ff. } 32- \\
35\end{array}$ & Then Am I Not Obliged & $\begin{array}{l}\text { Am é lineau } \\
\text { 1907: } 85- \\
91^{510}\end{array}$ \\
\hline 279-end & \multicolumn{4}{|l|}{ Missing } \\
\hline
\end{tabular}

Table 5: Pages, institutions, shelf numbers, contents, and publications for MONB.XF.

\footnotetext{
${ }^{505}$ Young 2000: 88 has an excerpt from this folio.

${ }^{506}$ Munier provides a facsimile edition drawn by hand. Young 2000: 97 has an excerpt from this folio.

${ }^{507}$ Pp. 179-80 and 191-92 are fragmentary.

${ }^{508}$ Cf. Wiesmann's Latin translation with intertext information, which can be found in Wiesmann 1931:
}

$112-14$.

${ }^{509}$ Full text of pp. 203-14 is included in Zoega 1810: 385-89. Excerpts from pp. 215-68 are included in Zoega 1810: 390-401.

${ }^{510}$ Excerpts are included in Zoega 1810: 401. In addition, photos of pp. 271-74 are available in Amélineau 1907: 322, and excerpts of pp. 275-78 are included in Amélineau 1907: xlviii. 
In addition, seven leaves do not have any page numbers in MONB.XF (see Table 6). The first

folio is fragmented; three fragments of it were discovered at the Coptic Museum in Cairo.

\begin{tabular}{|c|c|c|c|c|}
\hline $\begin{array}{l}\text { Number } \\
\text { of pages }\end{array}$ & Institution & Shelf no. & Contents & Publications \\
\hline \multirow{3}{*}{$2^{511}$} & Coptic Museum, Cairo & inv. 2631/111 & \multirow{3}{*}{$\begin{array}{l}\text { People Have } \\
\text { Not Understood }\end{array}$} & Unpublished \\
\hline & Coptic Museum, Cairo & C.G. 9255 f. 1 & & Munier 1916: 71-72 \\
\hline & Coptic Museum, Cairo & C.G. 9255 f. 3 & & $\begin{array}{l}\text { Munier 1916: 72-73, } \\
188^{512}\end{array}$ \\
\hline $2^{513}$ & $\begin{array}{l}\text { Bibliothèque Nationale de } \\
\text { France, Paris }\end{array}$ & Copte $130^{5}$ f. 116 & Unidentified & Unpublished \\
\hline $2^{514}$ & $\begin{array}{l}\text { Bibliothèque Nationale de } \\
\text { France, Paris }\end{array}$ & Copte $130^{5}$ f. 117 & Unidentified & Unpublished \\
\hline $2^{515}$ & $\begin{array}{l}\text { Bibliothèque Nationale de } \\
\text { France, Paris }\end{array}$ & Copte $130^{5}$ f. 118 & Unidentified & Unpublished \\
\hline $2^{516}$ & $\begin{array}{l}\text { Bibliothèque Nationale de } \\
\text { France, Paris }\end{array}$ & Copte $130^{5}$ f. 119 & Unidentified & Unpublished \\
\hline $2^{517}$ & $\begin{array}{l}\text { Beinecke Rare Book and } \\
\text { Manuscript Library, New } \\
\text { Haven }\end{array}$ & GEN MS Coptic 3 & Unidentified & Unpublished \\
\hline $2^{518}$ & $\begin{array}{l}\text { Bibliothèque Nationale de } \\
\text { France, Paris }\end{array}$ & Copte $130^{5}$ f. 112 & Unidentified & Unpublished \\
\hline
\end{tabular}

Table 6: Institutions, shelf numbers, contents, and publications of pages without page numbers for MONB.XF.

${ }^{511}$ Emmel 2004c named this "frag. 1." In addition, he labeled each fragment “1a.," "1b.," and "1c." in the same order as in Table 6. See Emmel 2004c: 463.

${ }^{512}$ Lantschoot 1929: 1.1: 149, 1.2: 59 contains excerpts.

${ }^{513}$ Emmel 2004c calls this folio "frag. 2."

514 “Frag. 3” in Emmel 2004c.

515 “Frag. 4" in Emmel 2004c.

516 "Frag. 5" in Emmel 2004.

517 "Frag. 6" in Emmel 2004.

518 "Frag. 7” in Emmel 2004. 
Pages $47-48,77-78,87-88,155-56,179-80$, and 191-92 are fragmentary, but their page numbers are preserved. Emmel also added seven fragments, but their page numbers are lost. ${ }^{519}$

Table 7 shows pages in the five works of Canon 6 as a percentage of total pages in MONB.XF. At 55 pages, Is It Not Written had the highest percentage of pages, followed by He Who Sits Upon His Throne with 26 pages and Then Am I Not Obliged with 20 pages. In addition, People Have Not Understood is preserved on two pages, while Remember, O Brethren is preserved on five pages.

\begin{tabular}{|c|c|c|c|c|c|}
\hline MONB.XF & $\begin{array}{ll}\text { He Who Sits } \\
\text { Upon } & \text { His } \\
\text { Throne } & \end{array}$ & $\begin{array}{l}\text { Remember, } O \\
\text { Brethren }\end{array}$ & $\begin{array}{l}\text { Is It Not } \\
\text { Written }\end{array}$ & $\begin{array}{l}\text { Then Am I Not } \\
\text { Obliged }\end{array}$ & $\begin{array}{l}\text { People Have } \\
\text { NotUnderstood }\end{array}$ \\
\hline Number & 26 & 5 & 55 & 20 & 2 \\
\hline Percentage & $23 \%$ & $4 \%$ & $48 \%$ & $18 \%$ & $7 \%$ \\
\hline
\end{tabular}

Table 7: Number of pages per work as a percentage of total number of pages in MONB.XF.

\subsubsection{MONB.XM}

MONB.XM is the best-preserved codex in Canon 6. Its PAThs ID is CLM $614 .{ }^{520}$ Each page contains two columns, and each column contains 30 lines on average. The ekthesis is relatively small, usually extending over less than 1.5 lines. The part of MONB.XM that spans the first page to p. 143 has not yet been found. Table 8 shows the pages, institutions, shelf numbers, contents, and publications associated with MONB.XM.

\footnotetext{
${ }^{519}$ See "Unplaced Fragments" in Emmel 2004c: 463.

520 “paths.manuscripts.614,” PAThs, http://paths.uniroma1.it/atlas/manuscripts/614, last accessed on
}

October 8, 2021. 


\begin{tabular}{|c|c|c|c|c|}
\hline Pages & Institution & Shelf no. & Contents & Publications \\
\hline $1-142$ & \multicolumn{4}{|l|}{ Missing } \\
\hline $143-44$ & $\begin{array}{l}\text { Bibliothèque } \\
\text { Nationale de } \\
\text { France, Paris }\end{array}$ & $\begin{array}{l}\text { Copte } 130^{1} \\
\text { ff. } 35-36\end{array}$ & Is It Not Written & Young 2000: 90-91 \\
\hline $145-52$ & \multicolumn{4}{|l|}{ Missing } \\
\hline $153-54$ & $\begin{array}{l}\text { Bibliothèque } \\
\text { Nationale de } \\
\text { France, Paris }\end{array}$ & $\begin{array}{l}\text { Copte } 130^{1} \mathrm{f} \text {. } \\
36\end{array}$ & Is It Not Written & Young 2000: 92-93 \\
\hline $154-56$ & \multicolumn{4}{|l|}{ Missing } \\
\hline $157-58$ & $\begin{array}{l}\text { Österreichische } \\
\text { Nationalbibliothek, } \\
\text { Vienna }\end{array}$ & K 9868 & Is It Not Written & Young 2000: 94-95 \\
\hline $159-74$ & \multicolumn{4}{|l|}{ Missing } \\
\hline $175-90$ & $\begin{array}{l}\text { Bibliothèque } \\
\text { Nationale } \\
\text { France, Paris }\end{array}$ & $\begin{array}{l}\text { Copte } 130^{1} \\
\text { ff. } 1-7\end{array}$ & Is It Not Written & Leipoldt 1906: 188-95 \\
\hline $171-270$ & \multicolumn{4}{|l|}{ Missing } \\
\hline $271-316$ & $\begin{array}{l}\text { Bibliothèque } \\
\text { Nationale } \\
\text { France, Paris }\end{array}$ & $\begin{array}{l}\text { Copte } 130^{1} \\
\text { ff. } 38-60\end{array}$ & $\begin{array}{l}\text { Then Am I Not } \\
\text { Obliged }\end{array}$ & Amélineau 1907: 75-111 521 \\
\hline $317-18$ & \multicolumn{4}{|l|}{ Missing } \\
\hline $319-48^{522}$ & $\begin{array}{l}\text { Bibliothèque } \\
\text { Nationale } \\
\text { France, Paris }\end{array}$ & $\begin{array}{l}\text { Copte } 130^{1} \\
\text { ff. } 61-76\end{array}$ & $\begin{array}{l}\text { Then Am I Not } \\
\text { Obliged }\end{array}$ & Amélineau 1907: 111-35 \\
\hline $349-80$ & \multicolumn{4}{|l|}{ Missing } \\
\hline $381-82$ & $\begin{array}{l}\text { Bibliothèque } \\
\text { Nationale de } \\
\text { France, Paris }\end{array}$ & $\begin{array}{l}\text { Copte } 130^{1} \mathrm{f} . \\
77\end{array}$ & $\begin{array}{l}\text { Then Am I Not } \\
\text { Obliged }\end{array}$ & Amélineau 1907: 135-37 \\
\hline $383-460$ & \multicolumn{4}{|l|}{ Missing } \\
\hline $461-76$ & $\begin{array}{l}\text { Bibliothèque } \\
\text { Nationale de } \\
\text { France, Paris }\end{array}$ & $\begin{array}{l}\text { Copte } 130^{1} \\
\text { ff. } 78-85\end{array}$ & $\begin{array}{l}\text { Then Am I Not } \\
\text { Obliged }\end{array}$ & $\begin{array}{l}\text { Leipoldt } 1913 \text { 4: 41-49; }{ }^{524} \\
\text { Amélineau 1907: 137-49 }\end{array}$ \\
\hline $477-80$ & \multicolumn{4}{|l|}{ Missing } \\
\hline
\end{tabular}

${ }^{521}$ Photos of pp. 279-86, 303-16 are in Amélineau 1907: 322 and those of pp. 293-98 and 321-46 in Amélineau 1907: 323. Pp. 283-84 are also contained in Maspero 1886: 143 (no. 5). Excerpts from pp. 287-88 are included in Amélineau 1907: xiix.

${ }^{522}$ With the folio of 333 bis and 334 bis as Copte $130^{1}$ f. 69.
${ }^{523}$ Photos of pp. $321-46$ are in Amélineau 1907: 323 .
${ }^{524}$ For the Latin translation and intertextuality information, see Wiesmann 1936: 24-30. 


\begin{tabular}{|c|c|c|c|c|}
\hline $481-84$ & $\begin{array}{l}\text { Bibliothèque } \\
\text { Nationale de } \\
\text { France, Paris }\end{array}$ & $\begin{array}{l}\text { Copte } 130^{1} \\
\text { ff. } 86-87\end{array}$ & $\begin{array}{l}\text { Then Am I Not } \\
\text { Obliged }\end{array}$ & Leipoldt 1913: 49-52 $2^{525}$ \\
\hline $485-542$ & \multicolumn{4}{|l|}{ Missing } \\
\hline $543-54$ & $\begin{array}{l}\text { Biblioteca } \\
\text { Nazionale } \\
\text { Napoli, Naples }\end{array}$ & $\begin{array}{l}\text { IB } 3 \text { ff. 36- } \\
41\end{array}$ & $\begin{array}{l}\text { Then Am I Not } \\
\text { Obliged }\end{array}$ & Amélineau 1907: 150-58 526 \\
\hline $555-58$ & \multicolumn{4}{|l|}{ Missing } \\
\hline $559-60$ & $\begin{array}{l}\text { Rijksmuseum van } \\
\text { Oudheden, Leiden }\end{array}$ & 148, Ins. 89 & $\begin{array}{l}\text { People Have Not } \\
\text { Understood }\end{array}$ & Pleyte and Boeser 1897: 409-11 $1^{527}$ \\
\hline 561-end & \multicolumn{4}{|l|}{ Missing } \\
\hline
\end{tabular}

Table 8: Pages, institutions, shelf numbers, contents, and publications for MONB.XM.

Table 9 shows the number of pages per work in MONB.XM as a percentage of the total number of pages in the codex. Over $80 \%$ of the content of MONB.XM (114 pages) spans Then Am I Not Obliged. Thus, this codex is the largest source for Then Am I Not Obliged of the existing codices of Canon 6. Moreover, MONB.XM includes 20 pages from Is It Not Written and two pages from People Have Not Understood.

\begin{tabular}{llllll}
\hline MONB.XM & $\begin{array}{l}\text { He Who Sits } \\
\text { Upon His } \\
\text { Throne }\end{array}$ & $\begin{array}{l}\text { Remember, } O \\
\text { Brethren }\end{array}$ & $\begin{array}{l}\text { Is It Not } \\
\text { Written }\end{array}$ & $\begin{array}{l}\text { Then Am I Not } \\
\text { Obliged }\end{array}$ & $\begin{array}{l}\text { People Have } \\
\text { Not } \\
\text { Understood }\end{array}$ \\
\hline $\begin{array}{l}\text { Number of } \\
\text { pages }\end{array}$ & 0 & 0 & 20 & 114 & 2 \\
Percentage & $0 \%$ & $0 \%$ & $15 \%$ & $84 \%$ & $1 \%$ \\
\hline
\end{tabular}

Table 9: Number of pages per work as a percentage of total number of pages in MONB.XM.

\footnotetext{
${ }^{525}$ For the Latin translation and intertexuality information, see Wiesmann 1936: 30-31.

${ }^{526}$ Zoega 1810: 411-13 contains excerpts.

${ }^{527}$ von Lemm 1908 contains excerpts.
} 


\subsubsection{MONB.XV}

MONB.XV is the third best-preserved codex in Canon 6. Its PAThs ID is CLM $622 .{ }^{528}$ It features two columns on each page, and each column contains 29 lines on average. P. 13 contains diplès.

One folio from pp. 13-14 is unpublished and preserved at the Österreichische Nationalbibliothek. It seems that the page number $\overline{\mathrm{PNB}}$ (“152”) was accidentally skipped by the scribe. The pages, folios, institutions, shelf numbers, contents, and publications for MONB.XV are listed in Table 10.

\begin{tabular}{|c|c|c|c|c|}
\hline Pages & Institution & Shelf no. & Contents & Publications \\
\hline $1-12$ & \multicolumn{4}{|l|}{ Missing } \\
\hline $13-14^{529}$ & $\begin{array}{l}\text { Österreichische } \\
\text { Nationalbibliothek, } \\
\text { Vienna }\end{array}$ & K 939 & $\begin{array}{l}\text { He Who Sits } \\
\text { Upon His } \\
\text { Throne }\end{array}$ & Unpublished \\
\hline $15-60$ & \multicolumn{4}{|l|}{ Missing } \\
\hline $61-76$ & $\begin{array}{l}\text { Bibliothèque Nationale de } \\
\text { France, Paris }\end{array}$ & $\begin{array}{l}\text { Copte } \\
130^{2} \mathrm{ff} \\
12-19\end{array}$ & $\begin{array}{l}\text { Remember, } O \\
\text { Brethren }\end{array}$ & $\begin{array}{l}\text { Amélineau 1914: 311-23 (photos } \\
\text { on pp. 63-74) }\end{array}$ \\
\hline $77-96$ & \multicolumn{4}{|l|}{ Missing } \\
\hline $97-104$ & $\begin{array}{l}\text { Bibliothèque Nationale de } \\
\text { France, Paris }\end{array}$ & $\begin{array}{l}\text { Copte } 78 \\
\text { ff. } 43-46\end{array}$ & Is It Not Written & $\begin{array}{l}\text { Unpublished; Lefort 1939: 5-6 } \\
\text { contains an excerpt from pp. } 101- \\
02 \text { and a French translation }\end{array}$ \\
\hline $104-150$ & \multicolumn{4}{|l|}{ Missing } \\
\hline $\begin{array}{l}151 \text { and } \\
153^{530}\end{array}$ & $\begin{array}{l}\text { Bibliothèque Nationale de } \\
\text { France, Paris }\end{array}$ & $\begin{array}{l}\text { Copte } \\
130^{2} \text { f. } 24\end{array}$ & Is It Not Written & Unpublished $^{531}$ \\
\hline $154-73$ & \multicolumn{4}{|l|}{ Missing } \\
\hline 174-77 & $\begin{array}{l}\text { Österreichische } \\
\text { Nationalbibliothek, } \\
\text { Vienna }\end{array}$ & $\begin{array}{l}\text { K } 9228- \\
9229\end{array}$ & Is It Not Written & Wessely 1909: 110-13 \\
\hline
\end{tabular}

528 “paths.manuscripts.622,” PAThs, https://atlas.paths-erc.eu/manuscripts/622, last accessed on

October 8, 2021.

\footnotetext{
${ }^{529}$ Diplēs are attested on p. 13. For a history of diplēs, see Subsection 2.4.1.

${ }^{530}$ P.152 seems to have been accidentally skipped by the scribe.

${ }^{531}$ Young 2000: 89 contains excerpts.
} 


\begin{tabular}{|l|l|l|l|l|}
\hline $178-$ end & Missing \\
\hline \hline \multirow{3}{*}{$+?$} & Bibliothèque Nationale de & Copte & Then Am I Not & \multirow{2}{*}{ Unpublished } \\
& France, Paris & $131^{8} \mathrm{f}$. & Obliged & \\
\hline
\end{tabular}

Table 10: Pages, institutions, shelf numbers, contents and publications for MONB.XV.

In Table 11, the number of extant pages per work are shown as a percentage of total pages in MONB.XV. Most pages encompass Remember, O Brethren, or Is It Not Written, whereas He Who Sits Upon His Throne and Then Am I Not Obliged represent one folio each. No pages attested in MONB.XV are related to People Have Not Understood.

\begin{tabular}{|l|l|l|l|l|l|}
\hline MONB.XV & $\begin{array}{l}\text { He Who Sits } \\
\text { Upon His } \\
\text { Throne }\end{array}$ & $\begin{array}{l}\text { Remember, O } \\
\text { Brethren }\end{array}$ & $\begin{array}{l}\text { Is It Not } \\
\text { Written }\end{array}$ & $\begin{array}{l}\text { Then Am I Not } \\
\text { Obliged }\end{array}$ & $\begin{array}{l}\text { People Have } \\
\text { Not } \\
\text { Understood }\end{array}$ \\
\hline $\begin{array}{l}\text { Number of } \\
\text { pages or } \\
\text { fragments }\end{array}$ & 2 & 16 & 14 & 2 & 0 \\
\hline Percentage & $6 \%$ & $47 \%$ & $41 \%$ & $6 \%$ & $0 \%$ \\
\hline
\end{tabular}

Table 11: Number of pages per work as a percentage of total number of pages in in MONB.XV.

\subsubsection{MONB.YJ}

The PAThs ID of MONB.YJ is CLM $630 .{ }^{532}$ According to Emmel, ${ }^{533}$ the codex is a bimodular manuscript with similarities to other manuscripts in the Canons, namely MONB.GI from Canon 4; MONB.YR and MONB.ZS from Canon 7; MONB.BV, MONB.DF and MONB.FM from Canon 9; and

532 “paths.manuscripts.630,” PAThs, https://atlas.paths-erc.eu/manuscripts/630, last accessed on

October 8, 2021.

${ }^{533}$ Emmel 2004c: 85. 
MONB.XL (florilegium). It features two columns of 34 lines on average. Since MONB.YJ is extant from p. 5 and just one work from Canon 6, namely He Who Sits Upon His Throne, is contained in the preserved part, MONB.YJ may probably be another copy of Canon 6, although Emmel with caution keeps other possibilities open. Table 12 lists the extant pages of MONB.YJ, their institutions, shelf numbers, contents, and associated publications.

\begin{tabular}{|c|c|c|c|c|}
\hline Pages & Institution & Shelf no. & Contents & Publications \\
\hline $1-4$ & \multicolumn{4}{|l|}{ Missing } \\
\hline $5-8$ & $\begin{array}{l}\text { Biblioteca Nazionale di } \\
\text { Napoli, Naples }\end{array}$ & IB10 ff. 3-5 & $\begin{array}{l}\text { He Who Sits Upon } \\
\text { His Throne }\end{array}$ & Amélineau 1914: 309-11534 \\
\hline $9-10$ & \multicolumn{4}{|l|}{ Missing } \\
\hline $11-12$ & $\begin{array}{l}\text { Biblioteca Nazionale di } \\
\text { Napoli, Naples }\end{array}$ & IB10 f. 5 & $\begin{array}{l}\text { He Who Sits Upon } \\
\text { His Throne }\end{array}$ & Amélineau 1914: 296-99 \\
\hline $13-14$ & $\begin{array}{l}\text { Bibliothèque Nationale } \\
\text { de France, Paris }\end{array}$ & $\begin{array}{l}\text { Copte } 130^{5} \\
\text { f. } 58\end{array}$ & $\begin{array}{l}\text { He Who Sits Upon } \\
\text { His Throne }\end{array}$ & Unpublished \\
\hline $15-32$ & \multicolumn{4}{|l|}{ Missing } \\
\hline $33-34$ & $\begin{array}{l}\text { Biblioteca Nazionale di } \\
\text { Napoli, Naples }\end{array}$ & IB 10 f. 6 & $\begin{array}{l}\text { He Who Sits Upon } \\
\text { His Throne }\end{array}$ & Amélineau 1914: 309-11535 \\
\hline $35-36$ & $\begin{array}{l}\text { Österreichische } \\
\text { Nationalbibliothek, } \\
\text { Vienna }\end{array}$ & K 935 & $\begin{array}{l}\text { He Who Sits Upon } \\
\text { His Throne }\end{array}$ & Unpublished \\
\hline $37-38$ & \multicolumn{4}{|l|}{ Missing } \\
\hline $39-42$ & $\begin{array}{l}\text { Österreichische } \\
\text { Nationalbibliothek, } \\
\text { Vienna }\end{array}$ & K 936-937 & $\begin{array}{l}\text { He Who Sits Upon } \\
\text { His Throne }\end{array}$ & Unpublished \\
\hline $43-44$ & \multicolumn{4}{|l|}{ Missing } \\
\hline $45-46$ & $\begin{array}{l}\text { Österreichische } \\
\text { Nationalbibliothek, } \\
\text { Vienna }\end{array}$ & K 938 & $\begin{array}{l}\text { He Who Sits Upon } \\
\text { His Throne }\end{array}$ & Unpublished \\
\hline $47-48$ & $\begin{array}{l}\text { Biblioteca Nazionale di } \\
\text { Napoli, Naples }\end{array}$ & IB10 f. 7 & $\begin{array}{l}\text { He Who Sits Upon } \\
\text { His Throne }\end{array}$ & Amélineau 1914: $318-20^{536}$ \\
\hline 49-end & \multicolumn{4}{|l|}{ Missing } \\
\hline
\end{tabular}

Table 12: Pages, institutions, shelf numbers, contents, and publications for MONB.YJ.

\footnotetext{
${ }^{534}$ For photos, see Amélineau 1914: 551.

${ }^{535}$ For photos, see Amélineau 1914: 551.

${ }^{536}$ Zoega1810: 572 (no. 237) contains excerpts.
} 


\subsubsection{MONB.YK}

The PAThs ID of MONB.YK is CLM $631 .{ }^{537}$ MONB.YK may be a codex of Varia or another copy of Canon $6{ }^{538}$ Each page contains two columns, and each column contains 28 lines on average. The ekthesis is relatively large and usually extends over two lines. MONB.YK contains a folio of the text of Canon 6, namely pp. 587-88, which is preserved at the Bibliothèque Nationale de France as Copte $130^{5}$ f. 105 . This folio corresponds to the end of Then I Am Not Obliged and the end of People Have Not Understood. No editions of this folio were published.

${ }^{537}$ The PAThs URI is “paths.manuscripts.631.” See https://atlas.paths-erc.eu/manuscripts/631, last accessed on October 8, 2021.

${ }^{538}$ See Emmel 2004c: 167, "Because YK 587-588 bear the end of one work and the beginning of another that occur in this same order at the end of Canon 6, it is possible that YK is to be identified as another manuscript of this volume. However, I have not been able to discover any other parallels between YK and the four extant manuscripts of Canon 6. While the absence of other parallels might be just an accident. Canon 6 is well enough attested as to reduce significantly the chances of such an accident. Hence I have chosen not to treat YK as a complete manuscript of Canon 6, although this possibility should be reexamined in the light of any new textual evidence that might emerge [...]." 


\subsubsection{MONB.XL}

The PAThs ID of MONB.XL is $613 .{ }^{539}$ Also known as the Florilegium Sinuthianum, ${ }^{540}$ this codex is a compilation of selected writings by Shenoute from various Canons, Discourses, and other sources. Each page contains two columns of 35 lines on average. Fragment 1 corresponds to part of Remember O Brethren and the beginning of Is It Not Written. Pages 254-55 constitute a parallel text to a part of Then I Am Not Obliged. Table 13 shows the pages, institutions, shelf numbers, contents, and publications for MONB.XL.

\begin{tabular}{|l|l|l|l|l|}
\hline Pages & Institution & Shelf no. & Contents & Publications \\
\hline 254 & $\begin{array}{l}\text { Bibliothèque Nationale } \\
\text { de France, Paris }\end{array}$ & $\begin{array}{l}\text { Copte } \\
129^{12} \mathrm{f.} \mathrm{43r}\end{array}$ & $\begin{array}{l}\text { Then I Am } \\
\text { Not Obliged }\end{array}$ & $\begin{array}{l}\text { Bouriant 1889: 406-07, } \\
\text { Amélineau 1888: 590, Leipoldt } \\
\text { 1913: iv-v, 50-51 }\end{array}$ \\
\hline $\begin{array}{l}\text { 2 (no page } \\
\text { numbers) }\end{array}$ & $\begin{array}{l}\text { Österreichische } \\
\text { Nationalbibliothek, } \\
\text { Vienna }\end{array}$ & K 9594 & $\begin{array}{l}\text { Remember, } \\
\text { O Brethren }\end{array}$ & Unpublished \\
\hline
\end{tabular}

Table 13: Pages, institutions, shelf numbers, contents, and publications for MONB.XL.

\subsubsection{Biblical text reuses in Canon 6}

In older editions and translations of Canon 6, text reuses of the Bible-including quotations, allusions, paraphrases, and idiomatic expressions - were manually detected. However, these

\footnotetext{
${ }^{539}$ The PAThs URI is “paths.manuscripts.613.” See https://atlas.paths-erc.eu/manuscripts/613, last
} accessed on October 8, 2021.

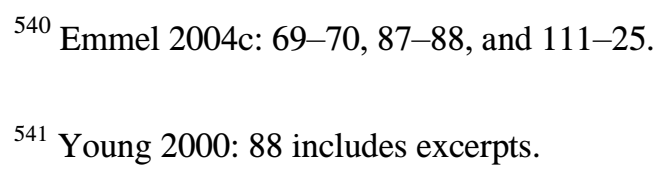


identifications were incomplete, and the function of quotations in the discourse was not discussed. ${ }^{542}$ Therefore, the present study continues from this point by focusing on the detection and analysis of text reuses in Canon 6 using various digital tools.

The footnotes of the main older editions of Shenoute's works (i.e., Amélineau and Leipoldt's editions, with Latin translations and a quotation index by Wiesmann) contain quotations from and allusions to the Bible. Table 14 shows the number of quotations and allusions indicated by Amélineau and Wiesmann, divided by biblical book. Dwight Young also found intertexts in a small number of pages, which he published, but they were not included in Table 14. As shown in Table 14, the most attested intertexts by Amélineau and Wiesmann were found to be from the Psalms, followed by Proverbs and the Gospel of John. However, the number of quotations from the Psalms was more than four times higher than that of quotations from Proverbs. Thus, of all the biblical books, Shenoute most frequently quoted from or alluded to the Psalms in Canon 6.

\begin{tabular}{l|ll}
\hline & New Testament & Old Testament \\
\hline Number of intertexts & 44 & 77 \\
Percentage & $36 \%$ & $64 \%$ \\
\hline
\end{tabular}

Table 14: Number of intertexts found by Amélineau and Wiesmann in Canon 6.

In Shenoute's Canon 6, the OT was used nearly 28 percentage points more than the NT as an intertext source. Only the portions of works in Canon 6 that Amélineau and Wiesmann analyzed for quotations and allusions were examined, but they did not cover all the pages reconstructed as Canon 6 and listed as extant pages by Emmel. In most cases, Amélineau and Wiesmann did not overlap, but there

\footnotetext{
${ }^{542}$ Behlmer 2008 and 2017.
} 
were overlaps in MONB.XM, pp. $461-76 .{ }^{543}$ Although Wiesmann found more intertexts than Amélineau, it is possible that Wiesmann consulted Amélineau, as his translation was published later than that of Amélineau. The pages that were not included in the scope of Amélineau and Wiesmann's analyses were MONB.XF, pp. 47-48, 77-78, 87-88, 155-56; MONB.XM, pp. 143-44, 153-54, 15758, 481-84, 559-60; MONB.XV, pp. 13-14, 97-104, 151, 153, 174-77; MONB.YJ, pp. 13-14, 35-36, 39-42, 45-46; and MONB.YK, pp. 587-88. Evidently, the fragments and missing pages in Emmel's list were not included in the counts of intertexts identified in previous studies and in the corpus of the present study. Table 15 and Table 16 show the numbers and percentages of intertexts from each biblical book in Shenoute in Canon 6, as identified by Amélineau and Wiesmann. Table 15 concerns the OT, while Table 16 concerns the NT.

${ }^{543}$ See Table 8. 


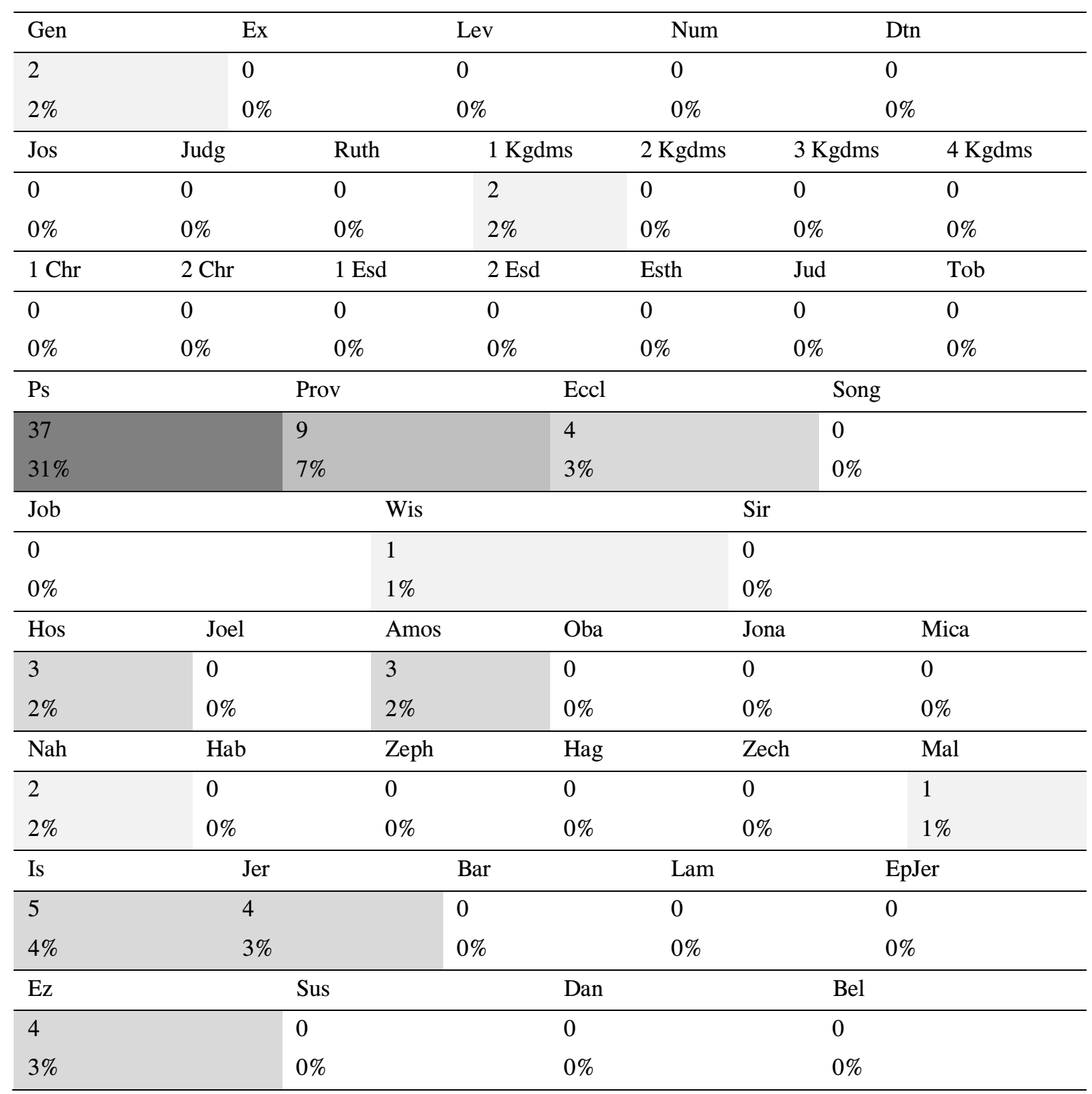

Table 15: Number of intertexts per book of the OT found by Amélineau and Wiesmann in Shenoute's Canon 6.

The percentages of the book genres for the total number of the OT intertexts in Shenoute's Canon 6 are: Pentateuch (2\%), Historical Books (2\%), Poetical Books (42\%), the Twelve Minor Prophets (7\%), and the Major Prophets and related books (11\%). ${ }^{544}$

${ }^{544}$ The Books of Maccabees I-IV, Odes, and the Psalms of Solomon were not considered parts of the Coptic Bible; see Feder 2020a: 223. 
Table 16 shows the number and percentage of intertexts from each book in the NT in Shenoute's

Canon 6.

\begin{tabular}{|c|c|c|c|c|c|c|c|c|}
\hline $\mathrm{Mt}$ & \multicolumn{2}{|c|}{$\mathrm{Mk}$} & \multicolumn{3}{|c|}{$\mathrm{Lk}$} & $\mathrm{Jn}$ & \multicolumn{2}{|c|}{ Acts } \\
\hline 5 & \multicolumn{2}{|c|}{4} & \multicolumn{3}{|c|}{5} & 8 & \multicolumn{2}{|c|}{0} \\
\hline $4 \%$ & \multicolumn{2}{|c|}{$3 \%$} & \multicolumn{2}{|c|}{$4 \%$} & & $7 \%$ & \multicolumn{2}{|c|}{$0 \%$} \\
\hline Rom & 1 Cor & 2 Cor & & Gal & & Eph & Phil & $\mathrm{Col}$ \\
\hline 1 & 4 & 3 & & 2 & & 1 & 0 & 0 \\
\hline $1 \%$ & $3 \%$ & $2 \%$ & & $2 \%$ & & $1 \%$ & $0 \%$ & $0 \%$ \\
\hline 1 Thes & 2 Thes & $\mathrm{Heb}^{545}$ & & $1 \mathrm{Tim}$ & & $2 \operatorname{Tim}$ & Tit & $\mathrm{Phm}$ \\
\hline 1 & 0 & 2 & & 0 & & 0 & 0 & 0 \\
\hline $1 \%$ & $0 \%$ & $2 \%$ & & $0 \%$ & & $0 \%$ & $0 \%$ & $0 \%$ \\
\hline Jam & 1 Pet & 2 Pet & $1 \mathrm{Jn}$ & & $2 \mathrm{Jn}$ & $3 \mathrm{Jn}$ & Jud & Rev \\
\hline 0 & 3 & 0 & 1 & & 0 & 0 & 1 & 3 \\
\hline $0 \%$ & $2 \%$ & $0 \%$ & $1 \%$ & & $0 \%$ & $0 \%$ & $1 \%$ & $2 \%$ \\
\hline
\end{tabular}

Table 16: Number of intertexts per book of the NT found by Amélineau and Wiesmann in Shenoute's Canon 6.

The percentages of the book genres for the total number of the NT intertexts in Shenoute's Canon 6 are: Gospels (18\%), Acts (0\%), Pauline Epistles (12\%), Catholic Epistles, and (4\%) Revelation $(2 \%)$.

Overall, the Psalms were the text with the most quotations and allusions in the parts of Canon 6 studied by Amélineau and Wiesmann. Intertexts from the Psalms account for $31 \%$ of all intertexts. The biblical book with the second-most quotations and allusions was Proverbs (7\%). This section provided detailed intertextual information about the Psalms and the pages of Canon 6. In the next section, similar information is presented for Besa's Letters and Sermons.

${ }^{545}$ The Letter to Hebrews was traditionally ascribed to Paul. 


\subsection{Besa's works}

Besa was Shenoute's successor and the fourth abbot and archimandrite of the White Monastery Federation. The works of Besa examined in this study are mainly based on Karl Heinz Kuhn's edition. ${ }^{546}$ Kuhn presented nine codices (Codices A-I) and separated them into 44 "fragments." In his usage, "fragments" does not refer to fragments of manuscripts but rather fragments of works, since many — but not all $—$ of the works preserved in these codices were incomplete due to lacunae and missing pages. Emmel identified that Codices $\mathrm{C}$ and $\mathrm{H}$ contained works by Shenoute, not Besa. ${ }^{547}$ Most of Besa's works are contained in MONB.BA and MONB.BB, ${ }^{548}$ which, like the manuscripts of Shenoute' works, have been dispersed across institutions all over Europe. Most of the codices are preserved at the Biblioteca Nazionale di Napoli and the British Library.

\footnotetext{
${ }^{546}$ Kuhn 1956a and 1956b.

${ }^{547}$ Emmel 2004c: 937.

${ }^{548}$ MONB.BA was named "Codex A" and MONB.BB was named "Codex B"; see Kuhn 1956a and
} $1956 b$. 


\subsubsection{MONB.BA}

The PAThs ID for MONB.BA is CLM 287. ${ }^{549}$ Also known as Kuhn's "Codex A," 550 MONB.BA measures approximately $31.5 \mathrm{~cm}$ in height and $26 \mathrm{~cm}$ in width. Each page contains two columns, and each column contains 29 lines on average. According to Kuhn, the script is a "regular square uncial" with a "small rounded uncial" in headings or subscriptions. ${ }^{551}$ MONB.BA sometimes contains diplēs, some of which indicate biblical quotations.

Kuhn dated these codices at the seventh to eighth centuries. They were written on parchment. According to Kuhn, on his codex A, which finds parallels in Codex B, the indication of the author is written as "дпа внса" (Apa Besa). The scribes attributed both Codices D and F to Besa, but Codices C, E, G, and $\mathrm{H}$ do not have any attributions. After consulting with Walter E. Crum, Johannes Leipoldt and Paul van Cauwenbergh, ${ }^{552}$ Kuhn ascribed these codices to Besa based on their style.

${ }^{549}$ While the Trismegistos ID and LDAB ID of the Canon 6 codices are not listed in the PAThs database, but the IDs of MONB.BA and MONB.BB are. In the PAThs database, MONB.BA is TM/LDAB 108394. See “paths.manuscripts.287,” PAThs, https://atlas.paths-erc.eu/?p=/manuscripts/287, last accessed on October 8, 2021.

${ }^{550}$ Kuhn 1956a: V-XIV: "but the internal evidence, i.e., subject-matter and style, together with the opinions of such scholars as W. E. Crum, J. Leipoldt, and P. van Cauwenbergh, has seemed to me sufficiently good ground for including these texts among the authentic writings of Besa."

\footnotetext{
${ }^{551}$ Kuhn 1965a: V.

${ }^{552}$ Kuhn 1956a: XIII-XIV.
} 
Kuhn summarized the contents of each fragment. ${ }^{553}$ In his classification, Fragments 1-2, 6-7,

11-14, and 20-35 belong to MONB.BA. In addition, MONB.BA and MONB.BB share parallel texts:

pp. 115-18 in MONB.BA are parallel to pp. 362-66, Fragment 4 in MONB.BB (On Repentance). Table

17 lists the pages, institutions, shelf numbers and contents of MONB.BA.

\begin{tabular}{|c|c|c|c|}
\hline Pages & Institution & Shelf no. & Contents \\
\hline $1-48$ & \multicolumn{3}{|l|}{ Missing } \\
\hline $49-56$ & $\begin{array}{l}\text { Biblioteca } \\
\text { Nazionale di } \\
\text { Napoli, Naples }\end{array}$ & $\begin{array}{l}\text { IB } 6, \text { ff. } 1- \\
4\end{array}$ & Fragment 1 (On Vigilance) \\
\hline $57-60$ & \multicolumn{3}{|l|}{ Missing } \\
\hline $61-62$ & $\begin{array}{l}\text { Biblioteca } \\
\text { Nazionale di } \\
\text { Napoli, Naples }\end{array}$ & $\begin{array}{l}\text { IB } 6 \text {, ff. 6- } \\
5\end{array}$ & Fragment 2 (Exhortations) \\
\hline $\begin{array}{l}\text { Exhortations } \\
63-114\end{array}$ & \multicolumn{3}{|l|}{ Missing } \\
\hline $115-18$ & $\begin{array}{l}\text { Biblioteca } \\
\text { Nazionale di } \\
\text { Napoli, Naples }\end{array}$ & $\begin{array}{l}\text { IB } 6 \text {, ff. 6- } \\
7\end{array}$ & Parallel to MONB.BB pp. $362-366$ \\
\hline 119-24 & \multicolumn{3}{|l|}{ Missing } \\
\hline $125-30$ & $\begin{array}{l}\text { Österreichische } \\
\text { Nationalbibliothek, } \\
\text { Vienna }\end{array}$ & $\begin{array}{l}\text { K } 965, \text { ff. } \\
1-3\end{array}$ & Fragment 6 (On Strife in the Community) \\
\hline $131-34$ & \multicolumn{3}{|l|}{ Missing } \\
\hline $135-40$ & $\begin{array}{l}\text { Österreichische } \\
\text { Nationalbibliothek, } \\
\text { Vienna }\end{array}$ & $\begin{array}{l}\text { K } 965, \mathrm{ff} . \\
4-6\end{array}$ & Fragment 7 (To an Erring Monk) \\
\hline $141-202$ & \multicolumn{3}{|l|}{ Missing } \\
\hline $203-52$ & $\begin{array}{l}\text { Biblioteca } \\
\text { Nazionale di } \\
\text { Napoli, Naples }\end{array}$ & $\begin{array}{l}\text { IB } 6, \text { ff. } 8- \\
32\end{array}$ & $\begin{array}{l}\text { Fragments } 11 \text { (To an Erring Monk, pp. 203-22), } 12 \\
\text { (Reproofs and Monastic Rules, pp. 222-44), } 13 \text { (To } \\
\text { Aphthonia, pp. 244-9), and } 14 \text { (To Antinoe, pp. 250-2) }\end{array}$ \\
\hline $253-364$ & \multicolumn{3}{|l|}{ Missing } \\
\hline $365-508$ & $\begin{array}{l}\text { British Library, } \\
\text { London }\end{array}$ & $\begin{array}{l}\text { Or. } 8810, \\
\text { ff. } 15-86\end{array}$ & $\begin{array}{l}\text { Fragments } 20 \text { (To Mary, Mother of John and Talou, pp. } \\
\text { 365-73), } 21 \text { (To Nuns Who Are Disrupting the }\end{array}$ \\
\hline
\end{tabular}

${ }^{553}$ See Kuhn 1956a: VI-X.

${ }^{554}$ When Kuhn researched Or. 8810, f. 15-86, it was preserved at the British Museum. However, as

previously mentioned in connection with the London Psalter, the latter merged with several national British 


\begin{tabular}{|c|c|c|c|}
\hline & & & $\begin{array}{l}\text { Community, pp. 373-79), } 22 \text { (To Mary, Sister of Matai, } \\
\text { pp. 379-84), } 23 \text { (On Theft and Deceitful Behavior, pp. } \\
\text { 384-98), } 24 \text { (On Stealing from the Sick, pp. 398-409), } \\
25 \text { (To Thieving Nuns, pp. 409-13), } 26 \text { (On } \\
\text { Transgressing the Laws of God and the Precepts of the } \\
\text { Fathers, pp. 413-24), } 27 \text { (To the Brethren on } \\
\text { Maintaining Unity, pp. 424-56), } 28 \text { (To Matthew, pp. } \\
\text { 456-67), } 29 \text { (To Antinoe, pp. 467-77), } 30 \text { (To Herai, } \\
\text { pp. 477-89), } 31 \text { (On Those Who Have Renounced Their } \\
\text { Constancy, pp. 489-92), and } 32 \text { (To Herai, }{ }^{555} \text { pp. 492- } \\
\text { 508) }\end{array}$ \\
\hline $509-510$ & \multicolumn{3}{|r|}{ ( } \\
\hline $511-14$ & $\begin{array}{l}\text { British Library, } \\
\text { London }\end{array}$ & $\begin{array}{l}\text { Or. } 8810, \\
\text { ff. } 87-88\end{array}$ & $\begin{array}{l}\text { Fragment } 33 \text { (Besa's Defense Against Unjust } \\
\text { Accusations, pp. 511-13) }\end{array}$ \\
\hline 515-18 & \multicolumn{3}{|l|}{ Missing } \\
\hline $519-22$ & $\begin{array}{l}\text { British Library, } \\
\text { London }\end{array}$ & $\begin{array}{l}\text { Or. } 8810, \\
\text { ff. } 89-90\end{array}$ & $\begin{array}{l}\text { Fragment } 34 \text { (Continuation of Besa's Defense, pp. 519- } \\
\text { 22) }\end{array}$ \\
\hline 523-end & \multicolumn{3}{|l|}{ Missing } \\
\hline $\begin{array}{l}\text { One folio } \\
\text { (no page } \\
\text { number) }\end{array}$ & $\begin{array}{l}\text { John Rylands } \\
\text { Library, Manchester }\end{array}$ & Ryl. 63 & Fragment 35 (A Denunciation of an Erring Nun) \\
\hline
\end{tabular}

Table 17: Pages, institutions, shelf numbers, and contents for MONB.BA.

The beginnings of Fragments 1, 2, 6, 11, 20, 33, 34, and 35 are missing, as are the ends of Fragments $1,2,7,14,32,33,34$, and 35 . Moreover, the ends of the first two fragments are missing. Fragment 35 (A Denunciation of an Erring Nun) consists of two folios (four pages) without page numbers, beginning and end of the work (A Denunciation of an Erring Nun), and is preserved at the John Rylands Library in Manchester. Since page numbers are missing, its position in MONB.BA is unknown.

libraries; thus, the British Library became independent from the British Museum in 1973 and now preserves most of the museum's Coptic manuscripts.

${ }^{555}$ Fragment 32 (To Herai) is a different letter with the same title as Fragment 30. 


\subsubsection{MONB.BB}

The PAThs ID of MONB.BB is $288 .{ }^{556}$ Called "Codex B" by Kuhn, its size is approximately $30.5 \mathrm{~cm}$ in height and 25 in width. There are two columns per page, and each column contains 28 lines on average. Kuhn described the style of the script as "a bold, late square uncial hand," with "rounded uncials" in two headings and "enlarged initials. ${ }^{" 557} \mathrm{He}$ dates it to the eight century. Diplēs occasionally mark biblical quotations. ${ }^{558}$

As shown in Table 18, the first 326 pages of this codex are lost. There are 20 pages missing after Fragment 3, 30 pages missing after Fragment 4, 42 pages missing after Fragment 8, 14 pages missing after Fragment 10, two pages missing after Fragment 16, and four pages missing after Fragments 17 and 19. The portion of the codex that spans p. 702 until the end has not yet been found. Fragments 3 , 4, 8, 9, 10, 15, 17, and 18 lack a beginning, while Fragments 3, 5, 9, 10, 15, 16, 17, and 19 lack an end. A parallel text to pp. $421-25$ of MONB.BA is preserved on two folios without pagination that are preserved at the Bibliothèque Nationale de France as Copte $130^{5}$ f.109-10.

\begin{tabular}{|l|l|l|l|}
\hline Pages & Institution & Shelf no. & Contents \\
\hline $1-326$ & Missing & \multicolumn{3}{|l|}{} \\
\hline $327-38$ & $\begin{array}{l}\text { Bibliothèque } \\
\text { Nationale de } \\
\text { France, Paris }\end{array}$ & $\begin{array}{l}\text { Copte 130 } \\
\text { ff. 8-13 }\end{array}$ & Fragment 3 (On the Punishment of Sinners) \\
\hline $339-58$ & Missing & \\
\hline
\end{tabular}

${ }^{556}$ See “paths.manuscripts.288," PAThs, https://atlas.paths-erc.eu/manuscripts/288, last accessed on October 8, 2021. This codex's Trismegistos ID and LDAB ID is 108395.

\footnotetext{
${ }^{557}$ Kuhn 1956a: VI-X.

${ }^{558}$ Kuhn 1956a: VI-X.
} 


\begin{tabular}{|c|c|c|c|}
\hline $359-70$ & $\begin{array}{l}\text { Biblioteca } \\
\text { Nazionale di } \\
\text { Napoli, Naples }\end{array}$ & $\begin{array}{l}\text { IB } 6 \mathrm{ff} \text {. } \\
33-8\end{array}$ & $\begin{array}{l}\text { Fragments } 4 \text { (On Repentance, pp. 359-63) and } 5 \text { (On } \\
\text { Faith, Repentance, and Vigilance, pp. 363-70) }\end{array}$ \\
\hline $371-90$ & \multicolumn{3}{|l|}{ Missing } \\
\hline $391-92$ & $\begin{array}{l}\text { Rijksmuseum van } \\
\text { Oudheden, Leiden }\end{array}$ & $\begin{array}{l}\text { Copte } 102 \\
\text { Insinger } \\
57^{559}\end{array}$ & Fragment 8 (On Sins of the Tongue) \\
\hline $393-434$ & \multicolumn{3}{|l|}{ Missing } \\
\hline $435-36$ & $\begin{array}{l}\text { Bibliothèque } \\
\text { Nationale de } \\
\text { France, Paris } \\
\end{array}$ & $\begin{array}{l}\text { Copte } 130^{1} \\
\text { ff. } 20\end{array}$ & Fragment $9(\text { On Obedience })^{560}$ \\
\hline $437-38$ & \multicolumn{3}{|l|}{ Missing } \\
\hline $439-40$ & $\begin{array}{l}\text { Bibliothèque } \\
\text { Nationale de } \\
\text { France, Paris }\end{array}$ & $\begin{array}{l}\text { Copte } 130^{1} \\
\text { ff. } 21\end{array}$ & Fragment 10 (On Obedience) \\
\hline $441-552$ & \multicolumn{3}{|l|}{ Missing } \\
\hline $553-62$ & $\begin{array}{l}\text { Biblioteca } \\
\text { Nazionale di } \\
\text { Napoli, Naples }\end{array}$ & $\begin{array}{l}\text { IB } 6 \text { ff. } \\
42-6\end{array}$ & $\begin{array}{l}\text { Fragment } 15 \text { (On Lack of Food, p. 553), } 16 \text { (On a } \\
\text { Famine, pp. 554-62) }\end{array}$ \\
\hline $563-64$ & \multicolumn{3}{|l|}{ Missing } \\
\hline $565-76$ & $\begin{array}{l}\text { Biblioteca } \\
\text { Nazionale di } \\
\text { Napoli, Naples }\end{array}$ & $\begin{array}{l}\text { IB } 6 \text { ff. } \\
47-52\end{array}$ & Fragment 17 Admonitions to Sinners \\
\hline $577-80$ & \multicolumn{3}{|l|}{ Missing } \\
\hline $581-94$ & $\begin{array}{l}\text { Biblioteca } \\
\text { Nazionale di } \\
\text { Napoli, Naples }\end{array}$ & $\begin{array}{l}\text { IB } 6 \text { ff. } \\
53-9\end{array}$ & $\begin{array}{l}\text { Fragment } 18 \text { (To Sinful Nuns, pp. 581-91), } 19 \text { (On the } \\
\text { Sinfulness of the Community, pp. 592-4) }\end{array}$ \\
\hline $\begin{array}{l}595-698 \\
\end{array}$ & \multicolumn{3}{|l|}{ Missing } \\
\hline $699-702$ & $\begin{array}{l}\text { Biblioteca } \\
\text { Nazionale di } \\
\text { Napoli, Naples }\end{array}$ & $\begin{array}{l}\text { IB } 6 \text { ff. } \\
39-40\end{array}$ & Parallel text to MONB.BA pp. $436-40$ \\
\hline 703-end & \multicolumn{3}{|l|}{ Missing } \\
\hline $\begin{array}{l}\begin{array}{l}\text { Four pages } \\
\text { (no page } \\
\text { numbers) }\end{array} \\
\end{array}$ & $\begin{array}{l}\text { Bibliothèque } \\
\text { Nationale de } \\
\text { France, Paris }\end{array}$ & $\begin{array}{l}\text { Copte } \\
130^{5}, \text { ff. } \\
109-10\end{array}$ & $\begin{array}{l}\text { Parallel text to MONB.BA pp. } 421-25 \text {; Kuhn 1956a: VI } \\
\text { located these four pages between p. } 594 \text { and p. } 699 \text {. }\end{array}$ \\
\hline
\end{tabular}

Table 18: Institutions, shelf numbers, and contents of pages in MONB.BB.

${ }^{559}$ Edited in Wessely 1901: 155 and Pleyte and Boeser 1897: 295ff.

${ }^{560}$ Kuhn 1956a: VIII, attributed this Fragment to (On Obedience), like the following Fragment 10. 


\subsubsection{Other codices}

Kuhn listed five additional codices: Codices $\mathrm{C}-\mathrm{G}$. However, Emmel concluded that these works were not composed by Besa but by Shenoute. ${ }^{561}$ According to Kuhn, the pages of Codex D measure 31 $\mathrm{cm}$ in height and $23 \mathrm{~cm}$ in width on average, with an average of 29 lines per column and two columns per page written in a rounded uncial. Kuhn dates Codex D to the ninth century. The page numbers on all surviving pages are missing. The work that corresponds to the surviving pages of Codex D is called A Catechesis Commemorating Shenoute and is referred to as Fragment 38 by Kuhn. The beginning and end of the work are missing.

Codex E is written in an "elegant square uncial" script with "some of the characteristics of the rounded uncial." In addition, this codex is characterized by enlarged initials. The pages measure $33 \mathrm{~cm}$ in height and $25 \mathrm{~cm}$ in width on average, with an average of 32 lines per column and two columns per page. Kuhn estimates that this codex was produced in the eighth or ninth centuries.

Codex F is written in a "regular square uncial" with ornamented rounded uncial headings and enlarged initials. There are 28 or 29 lines on average per column and two columns per page. The size of the pages is $23.5 \mathrm{~cm}$ by $16 \mathrm{~cm}$. Kuhn dated the codex to the seventh to eight centuries. Codex F contains Fragment 40 (On Faith, Repentance, and Vigilance) $)^{562}$ and Fragment 41 (On Sins of the Tongue, pp. 391-92), which are both missing an end.

\footnotetext{
${ }^{561}$ Emmel 2004c: 937.

562 The page numbers are unknown.
} 


\subsubsection{Biblical intertexts in Besa's works}

Because text reuses in Shenoute's Canon 6 were identified by different scholars in different times, the methods and accuracy of these identifications are inconsistent. By contrast, biblical text reuses in Besa's Letters and Sermons were identified by Kuhn with a high degree of accuracy. In addition to intertexts from the Bible, which account for $97 \%$ of all quotations, the remaining $3 \%$ of intertexts consist of quotations from named and unnamed patristic sources such as Pseudo-Clement and the Letters of Antony. The OT was the most frequent biblical source of intertexts (56\%), while the NT accounts for $41 \%$ of biblical intertexts (see Table 19).

\begin{tabular}{l|llll}
\hline & New Testament & Old Testament & $\begin{array}{l}\text { Patristic } \\
\text { quotations }\end{array}$ & Unknown \\
\hline $\begin{array}{l}\text { Number of text } \\
\text { reuses }\end{array}$ & 437 & 595 & 27 & 10 \\
\begin{tabular}{l} 
Percentage \\
\hline
\end{tabular} & $41 \%$ & $56 \%$ & $3 \%$ & $1 \%$ \\
\hline
\end{tabular}

Table 19: Number and percentage of intertexts found by Kuhn in Besa's works.

Among biblical sources, the five books that comprise the Pentateuch (i.e., Genesis, Exodus, Leviticus, Numbers, and Deuteronomy) accounted for 3\% of intertexts in Besa's works, while the Historical Books accounted for $1 \%$ of intertexts, the Poetical Books accounted for $27 \%$ of text reuses, the Minor Prophets accounted for 6\% of intertexts, and the Major Prophets and related prophetic books accounted for $19 \%$ of intertexts. Thus, for the OT, the Poetical Books (e.g., Psalms and Proverbs) had a high number of attestations, while the Historical Books (e.g., Judges and Ruth) had a low number of attestations. Table 20 presents the numbers and percentages of quotations from the OT in Besa's Letters and Sermons. 


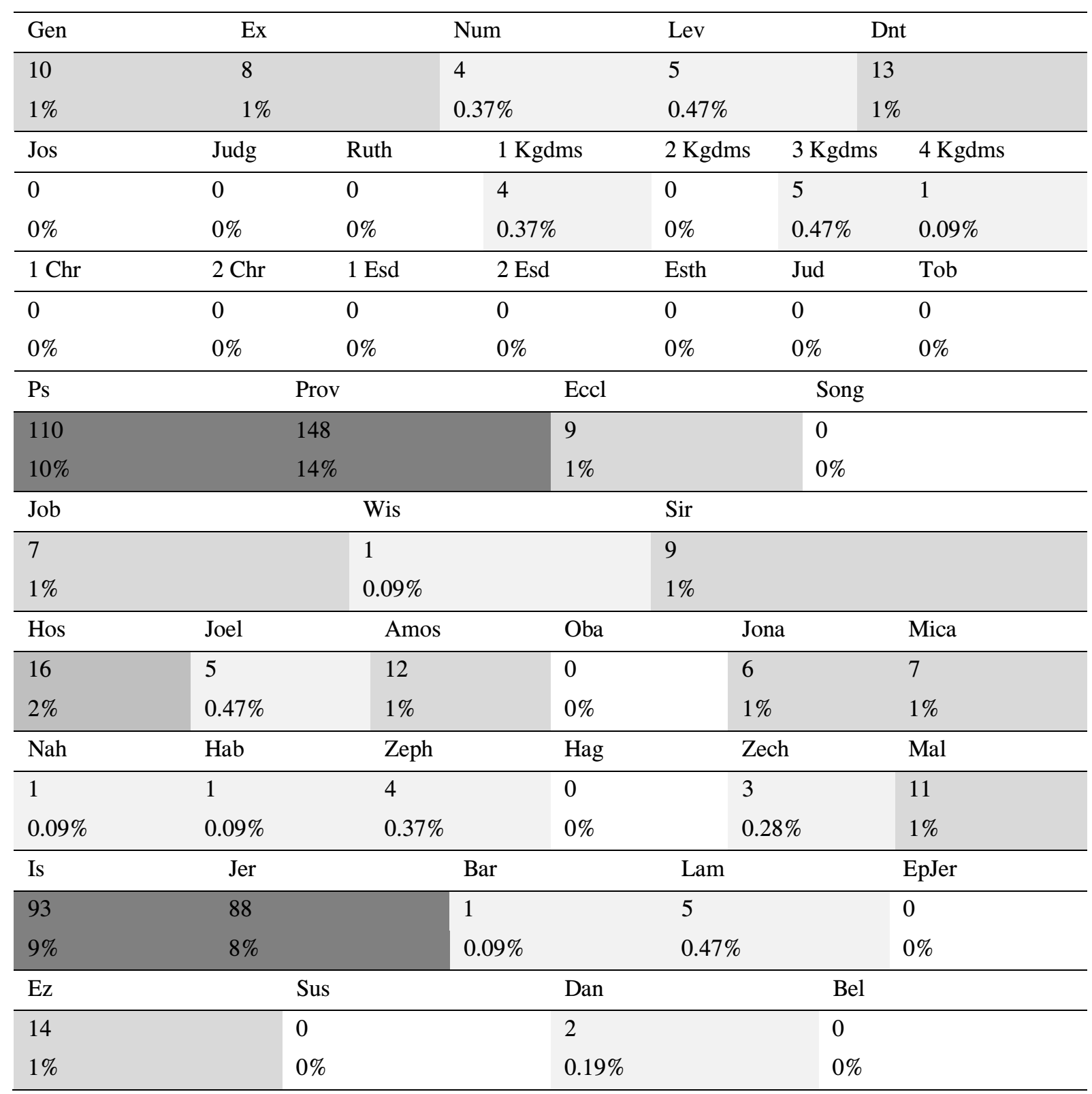

Table 20: Number of intertexts per book of the OT found by Kuhn.

The percentages of the book genres for the total number of the OT intertexts in Besa's Letters and Sermons are: Pentateuch (4\%), Historical Books, (1\%), Poetical Books (27\%), the Twelve Minor Prophets (6\%), and the Major Prophets and related books (19\%).

Among the Poetical Books, intertexts from Psalms and Proverbs were highly represented.

Proverbs was the most quoted biblical book, while Psalms is the second most frequently quoted biblical 
book. Notably, Besa did not quote Song of Songs, while Shenoute frequently quoted Song of Songs. ${ }^{563}$

In addition, Isaiah and Jeremiah dominated quotations from the Major Prophets, which indicates that

Besa assumed the same prophetic character as Shenoute.

In summary, the most-quoted books from the OT were (in order of frequency) Proverbs, Psalms, Isaiah, Jeremiah, Hosea, Deuteronomy, Amos, Ezekiel, and Malachi. Next, Table 21 shows the number and percentage of quotations from the NT in Besa's Letters and Sermons.

\begin{tabular}{|c|c|c|c|c|c|c|c|c|}
\hline Mt & \multicolumn{2}{|c|}{ Mk } & \multicolumn{2}{|c|}{$\mathrm{Lk}$} & \multicolumn{2}{|r|}{$\mathrm{Jn}$} & \multicolumn{2}{|c|}{ Acts } \\
\hline 63 & \multicolumn{2}{|c|}{18} & \multicolumn{2}{|c|}{44} & \multicolumn{2}{|r|}{19} & c & \\
\hline $6 \%$ & \multicolumn{2}{|c|}{$2 \%$} & \multicolumn{2}{|c|}{$4 \%$} & \multicolumn{2}{|r|}{$2 \%$} & \multicolumn{2}{|c|}{$1 \%$} \\
\hline Rom & 1 Cor & 2 Cor & & Gal & & Eph & Phil & Col \\
\hline 45 & 19 & 27 & & 10 & & 32 & 8 & 6 \\
\hline $4 \%$ & $2 \%$ & $3 \%$ & & $1 \%$ & & $3 \%$ & $1 \%$ & $1 \%$ \\
\hline 1 Thess & 2 Thess & $\mathrm{Heb}^{564}$ & & $1 \mathrm{Tim}$ & & $2 \mathrm{Tim}$ & Tit & Phil \\
\hline 14 & 7 & 33 & & 10 & & 9 & 4 & 0 \\
\hline $1 \%$ & $1 \%$ & $3 \%$ & & $1 \%$ & & $1 \%$ & $0.37 \%$ & $0 \%$ \\
\hline Jam & 1 Pet & 2 Pet & $1 \mathrm{Jn}$ & & $2 \mathrm{Jn}$ & $3 \mathrm{Jn}$ & Jud & Rev \\
\hline 16 & 23 & 11 & 3 & & 3 & 0 & 3 & 4 \\
\hline $2 \%$ & $2 \%$ & $1 \%$ & $0.28 \%$ & & $0.28 \%$ & $0 \%$ & $0.28 \%$ & $0.37 \%$ \\
\hline
\end{tabular}

Table 21: Number of intertexts per book of the NT found by Kuhn.

The percentages of the book genres for the total number of the NT intertexts in Besa's Letters and Sermons are: Gospels (13\%), Acts (1\%), Pauline Epistles (21\%), Catholic Epistles (6\%), and Revelation $(0.37 \%)$

\footnotetext{
${ }^{563}$ See Timbie 2011.

${ }^{564}$ The Letter to Hebrews was traditionally ascribed to Paul.
} 
The Gospels and the Pauline Epistles dominated quotations from the NT. Although quotations from the Book of Revelation were not common in the early fifth century, Kuhn found four quotations from Rev 7:17 in Besa's Letters and Sermons. However, he qualified this identification with the word "perhaps." The quotations that Kuhn identified in this corpus as being from the Book of Revelation could also be interpreted as quotations from Isaiah. Thus, the following paragraphs briefly review them and discuss whether Besa was more likely to have taken this quotation from a passage in Isaiah, which Rev 7:17 alluded to.

\section{Besa's Fragment 26/V/5 ${ }^{565}$ (On Transgressing the Laws of God and the Precepts of the Fathers)}

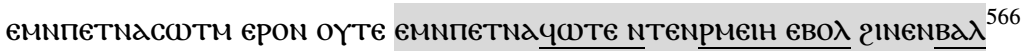

"For there will be no one who will hear us and no one who will wipe our tears from our eyes,

Besa's Fragment 5/II/2 (On Faith, Repentance, and Vigilance)

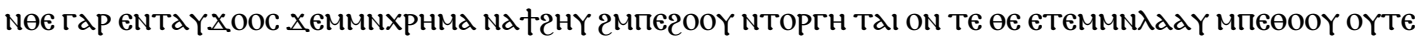

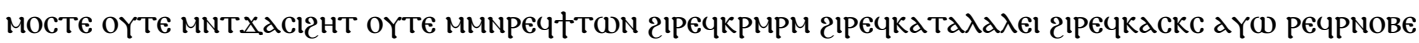

${ }^{565}$ Indications of fragment number, chapter number, and verse number in Besa's Letters and Sermons follow Kuhn 1956a. To see which fragment titles correspond to which fragment numbers, see Section 4.3.

${ }^{566}$ Kuhn 1956a: 77.

${ }^{567}$ Kuhn 1956b: 74. 


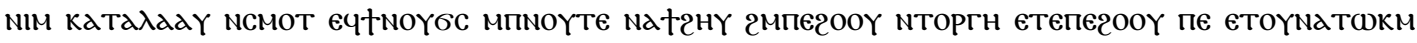

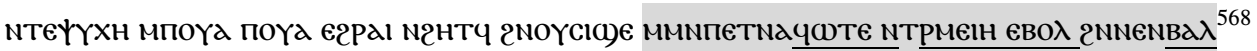

For as it has been said, 'Possessions shall not profit on the day of wrath', so also no wickedness, nor hatred, nor pride, nor quarrellers, murmurers, slanderers, whisperers, and no sinners of any kind who provoke God to anger, shall profit on the day of wrath, which is the day when the soul of each one shall be plucked out miserably, with no one to wipe the tears from our eyes and no one to hear us when we cry out. ${ }^{569}$

Besa's Fragment 12/III/1 (Reproofs and Monastic Rules)

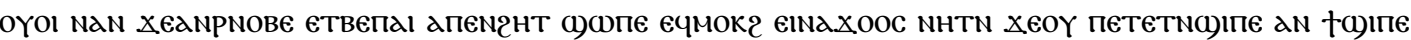

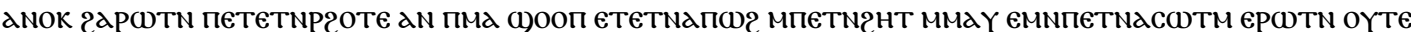

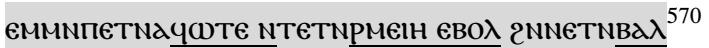

Woe to us for we have sinned! That is why our heart was grieved. What shall I say to you? Can it be that you are not ashamed? I am ashamed for you. Can it be that you are not afraid? There is a place where you shall break your hearts, for there will be no one who will hear you and no one who will $\underline{\text { wipe your tears from your eyes. }}$. $^{571}$

\footnotetext{
${ }^{568}$ Kuhn 1956a: 12.

${ }^{569}$ Kuhn 1956b: 11-12.

${ }^{570}$ Kuhn 1956a: 31.

${ }^{571}$ Kuhn 1956b: 29.
} 
Besa's Fragment 24/I/2 (To Nuns Who Are Disrupting the Community)

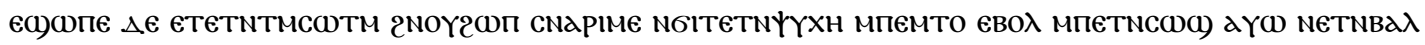

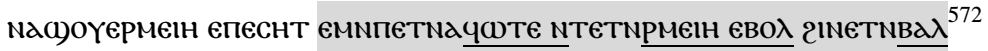

But if you do not hear, your soul will weep secretly confronted with your shame and your eyes will shed tears with no one to wipe your tears from your eyes. ${ }^{573}$

Source proposed by Kuhn: Rev 7:17

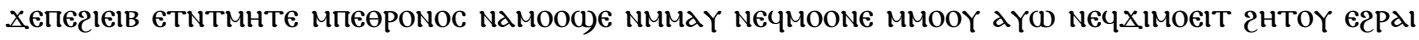

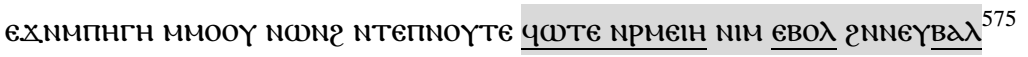

Because the lamb who is in the middle of the throne will walk with them. He fed them and he led them over the springs of living water and God wiped every tear away from their eyes. ${ }^{576}$

${ }^{572}$ Kuhn 1956a: 67-68.

${ }^{573}$ Kuhn 1956b: 65.

${ }^{574}$ The text of the quotation's proposed source (i.e., Rev 7:17) is presented below in Sahidic. All translations in the rest of this subsection are by the author.

${ }^{575}$ From the CoptOT base text. The NT part is based on the Askeland-Schulz edition of the Sahidic Bible; see Subsection 3.1.4. The text of Revelation was seemingly taken from Budge 1912, which contains a transcription of Or. 6802 from the British Library.

${ }^{576}$ Author's own translation. 
The common phrase between these four passages from Besa and Rev 7:17 іs рмєाн єво $2 \mathrm{~N}^{-}$ PRONOUN-Bג入 “tear from PRONOUN's eye." Is 25:8 has been proposed as a reference to this verse (and the similarly worded Rev 21:4). As Besa assumed the role of an OT prophet in his interactions with audiences on numerous occasions and considering the general rarity of quotations from Revelation, it is plausible to propose an adaptation from the verse in Isaiah:

\section{Source: Is $25: 8$}

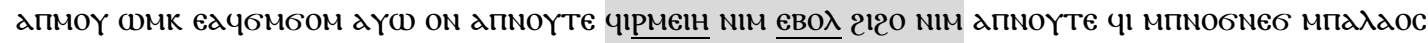

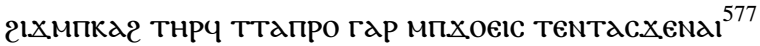

Death swallowed (them) after having prevailed, and again God took every tear away from every face. God took the reproach from my people on the entire earth, for the mouth of the Lord is it that said this. ${ }^{578}$

The quoted phrase itself is short; thus, the source is difficult to determine. The form of the

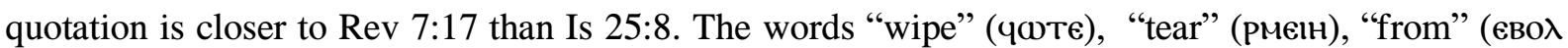

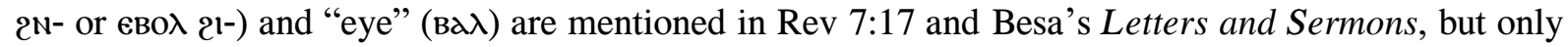
"tear" (Рмєاн) and "from" (єво入 21-) in Is 25:8. Although a quotation from Isaiah seems more likely based on Besa's rhetoric and his preference for quotations from the prophetical books, the closeness of the wording makes it seem more likely that Rev 7:17 was the source of Besa's quotation.

\footnotetext{
${ }^{577}$ The Coptic text was taken from the CoptOT base text, which is based on Bąk 2014.

${ }^{578}$ This is a translation of the present author.
} 
Lastly, the area of patristic quotations requires more analysis. This will be possible once a massive corpus of Coptic and Greek patristic literature is made available online in digital format. Table 22 is the numbers and percentages of the intertexts from patristic and unknown works, found by Kuhn, in Besa's Letters and Sermons.

\begin{tabular}{|c|c|c|c|c|}
\hline Shenoute (prob.) & Antony & Possibly Antony & Pseudo-Athanasius & Anonymous \\
\hline 4 & 5 & 1 & 3 & 7 \\
\hline $0.37 \%$ & $0.47 \%$ & $0.09 \%$ & $0.28 \%$ & $0.65 \%$ \\
\hline "father" & "fathers" & $\begin{array}{l}\text { "those of } \\
\text { understanding" }\end{array}$ & "wise men" & Unidentified \\
\hline 9 & 2 & 1 & 1 & 3 \\
\hline $0.84 \%$ & $0.19 \%$ & $0.09 \%$ & $0.09 \%$ & $0.28 \%$ \\
\hline
\end{tabular}

Table 22: Number of intertexts per author found by Kuhn in Besa's Letters and Sermons.

\subsection{Chapter summary}

This chapter discusses the composition of the corpus used for the TRACER analysis, which is presented in the next chapter. The corpus consists of three interconnected groups of sources: the Psalms, Shenoute's Canon 6, and Besa's Letters and Sermons. Editions and translations by Amélineau, Wiesmann, and others did not cover the entirety of quotations from and allusions to Psalms in Canon 6. In addition, identifications were sometimes incomplete. By contrast, Kuhn accomplished this task with a high degree of accuracy for Besa's Letters and Sermons.

A statistical analysis of quotations and allusions found by Amélineau and Wiesmann in Shenoute's Canon 6 and Kuhn in Besa's Letters and Sermons shows that the Book of Psalms is the most frequently quoted book by Shenoute and the second most frequently quoted by Besa. Thus, this demonstrates the Psalms' central position in biblical text reuse in the works of both authors. 


\section{Case study}

In Chapter 5, the results of the methodology discussed in Chapter 3 are presented. The study detected previously unidentified text reuses. This is perhaps unsurprising with regard to Shenoute's Canon 6, as previous studies did not cover the entire corpus of this canon. However, TRACER also found additional text reuses in Besa's works, which have been thoroughly studied by Kuhn. Moreover, TRACER detected quotations without indications that were unidentified in previous studies on the works of Shenoute and Besa. In addition, Chapter 5 analyzes text reuse tendencies from the Psalms in Shenoute's Canon 6 and Besa's Letters and Sermons, which TRACER found and previous studies did not detect.

Chapter 5 focuses on the results of a case study of potential text reuses in Shenoute and Besa's works detected using TRACER. While the software can find text reuse candidates, it cannot discern between specific types of text reuse. ${ }^{579}$ Therefore, types of text reuse had to be manually analyzed. In addition, some of the identified candidates were not verifiable text reuses. Rather, they were detected based on stop words that are frequently used in the texts (e.g., prepositions, articles, and auxiliaries). Furthermore, most of text reuses found by TRACER were idiomatic. TRACER often designated phrases such as рготе мгнту мпхоєıс/моүте ("fear the Lord/God") and мпємто мпхоєı//моүте ("in the presence of the Lord/God") as text reuses.

${ }^{579}$ For the classification of text reuse, see Subsection 2.2.1.1. 
Among the results, nearly no clear allusions were attested, but TRACER found more than 10 previously unknown quotations from the Book of Psalms in Besa's Letters and Sermons and Shenoute's Canon 6. These included ambiguous cases, such as heavily altered quotations or quotations with multiple possible texts of origin.

In this chapter, the provided English translations of the Psalms and Canon 6 passages are of the present author, while those of Besa's passages are of Kuhn.

\subsection{TRACER results}

TRACER processing was performed twice: once in July 2016 and once in August 2018. The July 2016 processing was performed on the text of Besa's Letters and Sermons, which was manually transcribed from Kuhns's edition. ${ }^{580}$ The text of Shenoute's Canon 6 was based on transcriptions that were subsequently converted into Unicode using a Unicode converter and divided into MONB.XM, MONB.XV, and MONB.XF. Codices MONB.YJ, MONB.XL, and MONB.YK were not included because the transcription of MONB.YJ, MONB.XL, and MONB.YK was not yet completed by the SFB 1136 subproject team until the first processing of TRACER in July 2016. The text of the Sahidic Bible was the base text of the CoptOT project (as of July 2016). However, this version lacked many biblical

\footnotetext{
${ }^{580}$ Kuhn 1956a.
} 
texts, such as Ecclesiastes and Proverbs. ${ }^{581}$ The results from TRACER's detection of text reuse candidates in July 2016 was as follows:

- Sahidic Bible $\rightarrow$ Besa's Letters and Sermons: 13,835 text reuse candidates

- Sahidic Bible $\rightarrow$ MONB.XM: 3,452 text reuse candidates

- Sahidic Bible $\rightarrow$ MONB.XV: 673 text reuse candidates

- Sahidic Bible $\rightarrow$ MONB.XF: 4,289 text reuse candidates

After processing, the identified text reuse candidates were so numerous that the required manual analysis of text reuse types would have been practically infeasible. Thus, the Psalms were chosen instead of the entire Sahidic Bible to make the sample size manageable. The Psalms were selected because they are one of the few biblical books that Shenoute and Besa frequently quoted (see Sections 4.3 and 4.4). ${ }^{582}$ The monks and nuns who heard Shenoute's Canon 6 and Besa's Letters and Sermons would have been very familiar with the Psalms, as discussed in Section 4.1. Additionally, the text of the Psalms has been well-attested in Sahidic Coptic by numerous manuscripts.

For the second processing session conducted in August 2018, the SFB 1136 subproject team completed the first full transcription of the Canon 6 codices: MONB.XF, MONB.XM, MONB.XV,

${ }^{581}$ As of November 13, 2021, the base text of the CoptOT projects contains the Sahidic translations of Proverbs and Ecclesiastes.

${ }^{582}$ See Tables 15, 16, 20, and 21. The book that Besa quoted most frequently in Letters and Sermons was Proverbs, and the book that he quoted second most frequently was the Psalms, according to Kuhn 1956a and $1956 b$. 
MONB.YJ, MONB.YK, and the Canon 6 portion of MONB.XL. ${ }^{583}$ The pages were transcribed in the VMR and compared to photos of the codices. Using the same method, the SFB 1136 subproject team also completed the transcription of the two main codices in Besa's works: MONB.BA and MONB.BB. ${ }^{584}$ The author produced the text files for TRACER from the XML files of these codices, which were exported from the VMR in EpiDoc format. ${ }^{585}$ During this process, the texts in Canon 6 were divided by works (incipits) rather than codices to reduce duplications in the corpus. Thus, the latter was more complete in July 2018 than it had been in July 2016. In addition, TRACER itself had undergone significant changes since 2016. In 2018, the results of the TRACER processing were as follows:

- Psalms $\rightarrow$ Besa: 629 text reuse candidates

- Psalms $\rightarrow$ Canon 6: text reuse candidates

- He Who Sits Upon His Throne: 84 text reuse candidates

- Remember, O Brethren: 31 text reuse candidates

○ Is It Not Written: 98 text reuse candidates

- Then Am I Not Obliged: 207 text reuse candidates

- People Have Not Understood: 3 text reuse candidates

\footnotetext{
${ }^{583}$ See Section 4.2.

${ }^{584}$ See Section 4.3.

${ }^{585}$ For details on the procedure using the VMR, see Subsections 3.2.1.2. For more on EpiDoc, see
} Bodard and Stoyanova 2016 and https://sourceforge.net/p/epidoc/wiki/Home, last accessed on August 13, 2021. 
The VMR contained all the diacritical marks and punctuation marks. However, for this research, the marks were deleted for processing. Then, the text reuse candidates found by TRACER were examined using the VMR's parallel view to ascertain whether they were truly cases of text reuse. If a candidate was determined to be a text reuse, the text reuse type was analyzed and the shared morphs were counted. If the candidate was an altered quotation, all alterations, additions, and deletions were analyzed.

\subsection{Quotations vs. idiomatic text reuses}

TRACER can identify two similar strings of characters in two corpora, but it cannot judge or classify types of text reuse. In literary studies, quotations and allusions are typically valued more than idiomatic text reuses ${ }^{586}$ unless the research specifically focuses on idiomatic phraseology. However, without recourse to a Coptic wordnet ${ }^{587}$ (which has been developed but not fully ready for TRACER yet), TRACER tends to find more idiomatic text reuses than quotations and allusions.

In some cases, it is difficult even for scholars to distinguish between idioms and quotations. The following subsections present examples of TRACER-detected text reuse candidates from specific parts of the Psalms in which the type of text reuse was ambiguous (quotations vs. idiomatic text reuses). Such

${ }^{586}$ For TRACER's taxonomy of text reuse, see Subsection 2.2.1.1.

${ }^{587}$ Slaughter et al. 2019. 
cases highlight the difficulty of basing classifications of text reuses on automatic identification, even with the latest software.

In Section 5.2, all text reuses are discussed by referring to their TR number. "TR" denotes text reuse. In this section below, typical examples of ambiguous cases are selected and presented.

\subsubsection{TR 1}

The first case is from Besa's Fragment 3. This passage from Fragment 3 has 12 shared morphs with Ps 110:5 (111:5). However, it is not a quotation but rather is coincidentally similar to Ps 110:5 $(111: 5)$.

\section{Besa's Fragment 3/II/3 (On the Punishment of Sinners)}

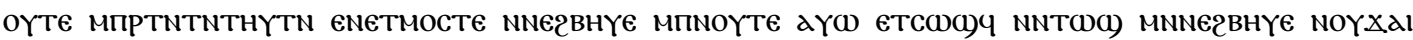

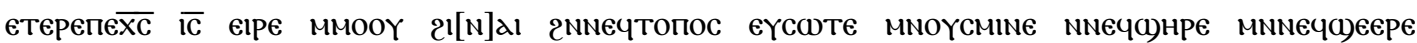

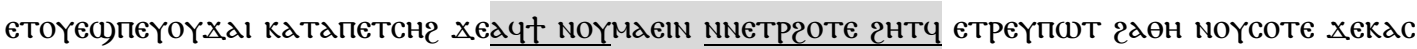
еремекмеріт NоYгм

And do not be like those who hate the things of God, and who despise the ordinances and the works of salvation which Christ Jesus thus performs in his monasteries, for a ransom and confirmation of his sons and daughters who desire their salvation, as it is written, "He has given a sign to those who fear him that they may flee from before the arrow, that your beloved may be saved." 588

${ }^{588}$ Kuhn 1956b: 5. 


\section{TRACER source candidate: Ps 110:5 (111:5)}

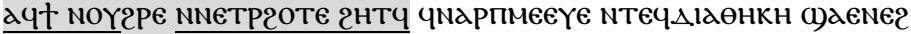

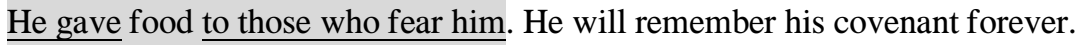

The above passage by Besa contains a QIP: катдпєтснг $\chi €$ - ("according to what is written that ...”). Therefore, it is highly probable that the phrase after this QIP is a quotation. TRACER suggested the pair Besa 3/II/3 and Ps 110:5 (111:5) as a possible text reuse candidate. Indeed, 12 morphs are common to both passages. Thus, the type of text reuse may be a near-verbatim quotation. ${ }^{589}$ This identification, which was not shared by Kuhn, is reviewed in this subsection. ${ }^{590}$

The construction of the source and target quotation is ayt nOYNOUN NNєTPготе 2нTY ("he gave a NOUN to those who fear him"). In addition, Р2оте 2нтч ("fear him") is the most frequent idiomatic text reuse in Besa and Shenoute's works. Because of the similarity in their construction, it would be inappropriate to simply identify or label this text reuse as an idiomatic text reuse, as it is possible that Besa actually quoted this phrase. Indeed, it is often used in other biblical passages.

The relation between Maein ("sign") and 2Pe ("food") is neither co-hyponymous nor synonymous. In fact, these two words have no semantic relation except for belonging to the same syntactic category (i.e., nouns). Thus, it is more likely that this text reuse is merely the reuse of an idiomatic text or frequent phrase or accidental correspondence. The context of this text reuse is that Besa

\footnotetext{
${ }^{589}$ For text reuse types, see Subsection 2.2.1.1.

${ }^{590}$ Kuhn 1956b: 5.
} 
tells his audience, whom he addresses as "beloved," to keep their faith in Jesus Christ and to not fall into lawlessness, like those who hate God. Thus, the text is unlikely to be a quotation from Ps 110:5 $(111: 5)$

\subsubsection{TR 2}

Kuhn did not identify Besa 3/II/3 as a quotation from Ps 110:5 (111:5). Instead, he suggested Ps 59:6-7 (60:6-7) as the source. Ps 59:6-7 (60:6-7) was also suggested as another possible text reuse candidate by TRACER. Not only does it contain more words that are shared with Besa $3 / \mathrm{II} / 3$, but it is also much closer to the content as shown below in the comparison of the two passages than Ps 110:5 (111:5). Thus, like Ps 59:6-7 (60:6-7), TRACER offers text reuse candidates that are very likely to be quotations. However, they may not be quotations but rather coincidentally similar texts, as the true source of the Besa passage in TR 1 is Ps 110:5 (111:5). Thus, researchers must carefully decide whether the text reuse candidates constitute meaningful intertexts or coincidentally similar texts or idiomatic text reuses.

Besa's Fragment 3/II/3 (On the Punishment of Sinners) [...] катапетснг Хед NоYгм $[\ldots]$ 
[...] as it is written, ${ }^{591}$ "He has given a sign to those who fear him that they may flee before an arrow, that your beloved may be saved." $[\ldots]^{592}$

Source candidate: Ps 59:6-7 (60:6-7)

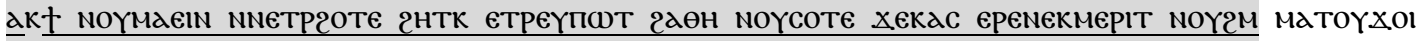
2NTEKOYNaM мгсотм єPOI $[\ldots]$

You have given a sign to those who fear you that they may flee before an arrow, that your beloved may be saved. Save with your right hand and listen to me. [...]

The subject of Ps 59:6-7 (60:6-7) is masculine second-person singular, while Besa changed this to masculine third-person singular. TRACER flagged both Ps 110:5 (111:5) and 59:6-7 (60:6-7) as text reuse candidates; however, manual processing was required to determine which passage Shenoute was referring to. The next example is also a problematic case in terms of judging the type and source of the text reuse.

\subsubsection{TR 3}

\section{Besa's Fragment 3/X/1 (On the Punishment of Sinners)}

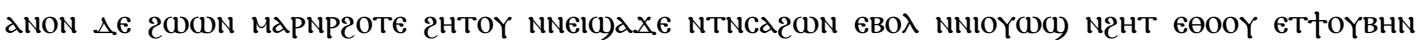

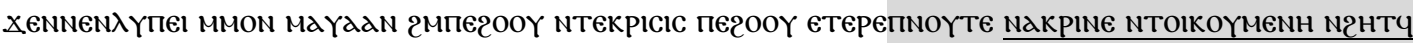

\footnotetext{
${ }^{591}$ In this study, QIPs are enclosed in a box. For a detailed description of QIPs, see Subsection 2.6.2.

${ }^{592}$ Kuhn 1956b: 5.
} 


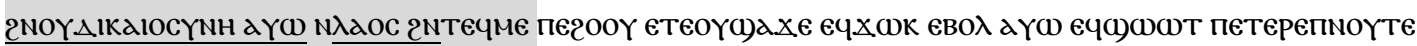
NAddY 2lXMחKd2

But as for us, let us revere these sayings, and depart from these evil aspirations which war against us, lest we make ourselves sorrowful on the day of judgment, the day when God shall judge the world in righteousness and the people in his truth, ${ }^{593}$ the day which is a sentence, completing and cutting short, which God will execute upon the earth. ${ }^{594}$

TRACER source candidate: Ps 97:9 (98:9)

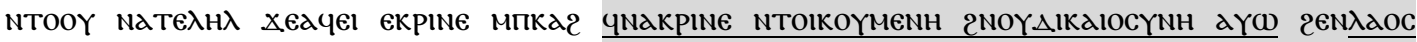
2NOYCOOYTN

They will rejoice because he came to judge the earth; he will judge the world in righteousness and people with uprightness.

This could be a near-verbatim quotation of dis-pronominalization of y- ("he") to пnOYTe ("God") with an alternation 2NoYcooYTN ("with uprightness") to 2NTEчMe ("with his truth"). In addition, if the case of TR 3 were a quotation, Besa would have deleted a plural indefinite article $2 \mathrm{EN}^{-}$("some") and inserted a preposition with a resumptive pronoun N2HTY ("in him"). CoOYTN ("uprightness") and M€ ("truth") are co-hyponyms under the hypernym "good virtue" and an indefinite singular article oY- ("a") and a feminine possessive article for the masculine third-person singular possessor Teq- ("his") before

${ }^{593}$ Ps 95:13 (96:13).

${ }^{594}$ Rom 9:28; Kuhn 1956b:8. 
these co-hyponyms are articles. In addition, there is a plural indefinite article $2 \mathrm{eN}^{\mathrm{N}}$ (“"some”) and a plural definite article $\mathrm{N}^{-}$("the") before the Greek loanword $\lambda$ doc ("persons"). Aside from the differences

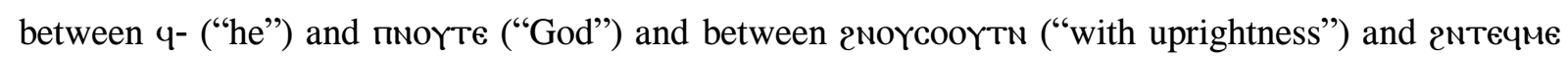
("with his truth"), and the deletions of $2 € \mathrm{~N}^{-}$("some") and the insertion of N2нTч ("in him"), there were 12 common morphs.

\subsubsection{TR 4}

Based on these characteristics, it is highly possible that the Besa passage contains a quotation from Ps 97:9 (98:9). There is no QIP in this passage. Kuhn did not notice this similarity. Instead, he suggested a quotation from Ps 95:13 (96:13). TRACER also detected this as a text reuse candidate.

Besa's Fragment 3/X/1 (On the Punishment of Sinners)

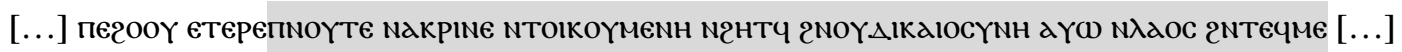

$[\ldots]$ the day when God shall judge the world in righteousness and the people in his truth $[\ldots]^{595}$

Source: Ps 95:13 (96:13)

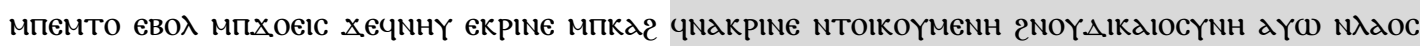
2NTEYME

${ }^{595}$ Kuhn 1956b:8. 
in the sight of the Lord, because he is coming to judge the earth, he will judge the world with $\underline{\text { righteousness and people with his truth. }}$

If Ps 95:13 (96:13) is the source text, Besa's Fragment 3/X/1 is a near-verbatim quotation that dispronominalizes ч- ("he") to пмоҮте (“God") and inserts a preposition with a resumptive pronoun

N2нTY "in it,"596 denoting the antecedent пе२०OY ("the day"). A comparison of Ps 95:13 (96:13) and Ps 97:9 (98:9) shows that the former shares more morphs with Besa's Fragment 3/X/1 than the latter (14 vs. 12). Thus, Ps 95:13 (96:13) is more likely to be the source text of the quotation used in Besa's Fragment 3/X/1.

\subsubsection{TR 5}

The next text reuse candidate is from Besa's Fragment 4/II/1. It was not identified as such by Kuhn and does not have a QIP. Although this candidate constitutes a potential text reuse, it is difficult to ascertain this without reasonable doubt.

\section{Besa's Fragment 4/II/1 (On Repentance)}

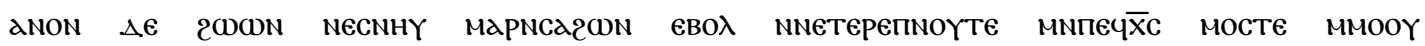

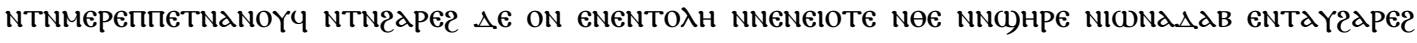

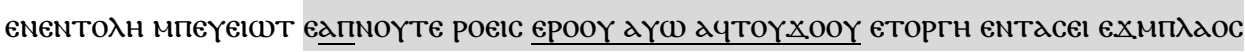

${ }^{596}$ A resumptive pronoun is a pronoun used in a relative clause, denoting the antecedent of the relative clause. 
But let us, brethren, depart from the things which God and his Christ hate, and let us love the good, and also keep the commandments of our fathers, like the sons of Jonadab who kept the commandments of their father, over whom God watched and whom he saved from the wrath which came upon the people. ${ }^{597}$

TRACER source candidate: Ps 33:18 (17 Budge; 34:17)

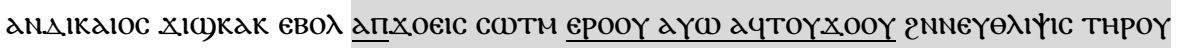
The righteous ones cried out. The Lord heard them, and he saved them in all their affliction.

The differences between these two passages are noYT€ vs. xoєıc and poєic vs. cotm between potential quotation and potential source text. The first pair of lexemes, norTe ("god") and xoeıc ("lord"), are synonyms that refer to the Judeo-Christian God, and the second lexeme pair, poeic ("watch") and corTM ("listen") are co-hyponyms under a hypernym that means "conceive." This text reuse candidate could represent a case of synonymic and co-hyponymic alternation, as both Besa's Fragment 4/II/1 and Ps 33:18 (34:17) use the same construction. However, it is difficult to ascertain whether it is a true quotation. Both contexts are similar, as they describe how God hears or watches the righteous and saves them.

${ }^{597}$ Cf. Jer 42:6 ff. according to Kuhn 1956b: 10. The English translation is from Kuhn 1956b: 9-10. 


\subsubsection{TR 6}

The next text reuse candidate also involves multiple possibilities. TRACER highlighted similarities between Fragment 5/I/2 of Besa's Letters and Sermons and Ps 15:1 (16:1), Ps 16:6 (17:6), and Ps 30:2-3 (1-2 Budge; 31:1-2). The Besa passage contains a QIP: катдпєтснг хє- ("according to what is written that..."). Thus, it is clear that it contains a quotation.

\section{Besa's Fragment 5/I/2 (On Faith, Repentance, and Vigilance)}

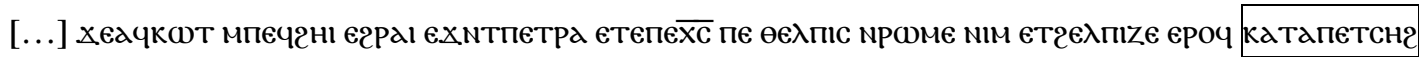

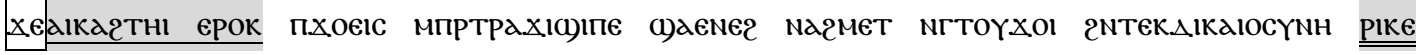
мпекмadXe ероі мгбепн етоүхоІ

[...] because he has built his house upon the rock ${ }^{598}$ which is Christ the hope of every man who sets his hope upon him, as it is written, 'I have put my trust in you, Lord, let me never be ashamed. Deliver me and save me in your righteousness. Incline your ear to me and hasten to save me..$^{599}$

TRACER source candidate 1: Ps 15:1 (16:1)

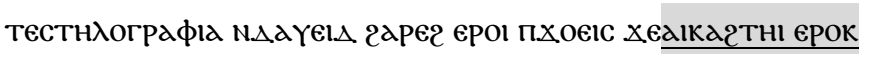

The stele inscription of David. Guard me, O Lord, because I trusted you.

${ }^{598}$ Cf. Mt 7:24 according to Kuhn 1956b: 11.

${ }^{599}$ Kuhn 1956b: 11. 


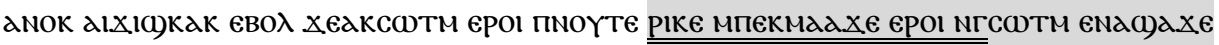

As for me, I cry out because you listened to me, O God, incline your ear to me and listen to my words!

First, the phrase alкג2TH єрок ("I trusted you") is featured in both Besa's Fragment 5/I/2 and Ps 15:1 (16:1). Thus, it is very likely a verbatim quotation. Second, the phrase pıкє мпєкмдахє єро мг("incline your ear to me and") is identical in Besa's Fragment 5/I/2 and Ps 16:6 (17:6). Besa subsequently uses бєпн єтоҮхо ("hasten to save me"), but Ps 16:6 (17:6) uses coтm емаa)dхе ("listen to my words"). Moreover, there are seven shared morphs between Besa's Fragment 5/I/2 and Ps 15:1 (16:1) and eight shared morphs between Besa's Fragment 5/I/2 and Ps 16:6 (17:6).

\subsubsection{TR 7}

Kuhn did not suggest that these were intertexts. In addition, there were longer matches with another passage in the Psalms, namely Ps 70:2 (71:2) and Besa's Fragment 5/I/2.

$\underline{\text { Besa's Fragment 5/I/2 (On Faith, Repentance, and Vigilance) }}$

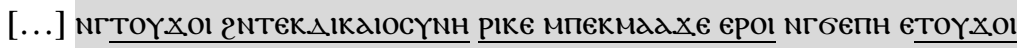

$[\ldots]$ rescue me in your righteousness; $\underline{\text { incline your ear to me and hasten to save me }}$.

${ }^{600}$ Kuhn 1956b: 11. 
Source: Ps 70:2 (71:2)

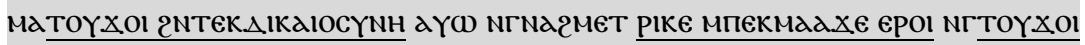

$\underline{\text { Rescue me in your righteousness }}$ and deliver me. Incline your ear to me and save me ${ }^{601}$

Ps 70:2 (71:2) is extremely similar to Besa's Fragment 5///2. In total, they share 13 morphs. Thus, all three passages from Psalms contain similar phrases as the passage in Besa. Usually, when such a high number of shared morphs are present, Besa's Fragment 5/I/2 is identified as quotations from Ps $70: 2(71: 2)$

\subsubsection{TR 8}

However, these text reuse candidates are probably not quotations from the above Psalms verses because, as Kuhn suggested, it is more likely that the part that encompasses the text reuse candidates is a quotation from Ps 30:2-3 (1-2 Budge; 31:1-2), as part of a large quotation from Ps 30:2-9 (1-8 Budge; 31:1-8), which continues after Besa's Fragment 5/I/2. ${ }^{602}$

$\underline{\text { Besa's Fragment 5/I/2 (On Faith, Repentance, and Vigilance) }}$

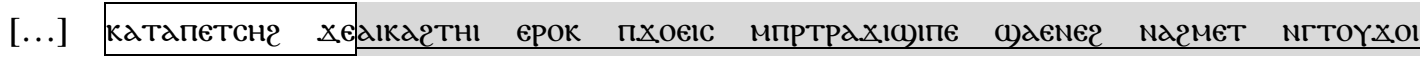

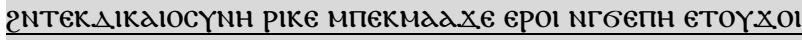

${ }^{601}$ Author's own translation.

${ }^{602}$ Kuhn 1956b: 11. 
[...] as it is written, "I have put my trust in you, Lord, let me never be ashamed. Deliver me and save me in your righteousness. Incline your ear to me and hasten to save me. ${ }^{, 603}$

Source: Ps 30:2-3

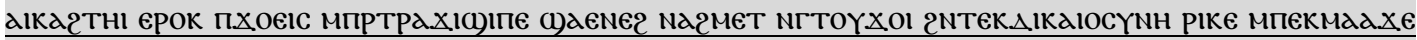

ероі мгбепн єтоүхо $[\ldots]$

I trust you, O Lord, do not let me ashamed forever, rescue me and save me in your righteousness;

Incline your ear to me and hasten to save me $[\ldots]$

Besa's Fragment 5/I/2 and Ps 30:2-3 (1-2 Budge; 31:1-2) share 37 morphs. Because of the passage's length and degree of agreement, there is no doubt that Ps 30:2-3 (1-2 Budge; 31:1-2) is the source of Besa's quotation. However, the phrases in Ps 30:2-3 (1-2 Budge; 31:1-2) were frequently used in other Psalms, as seen earlier in this subsection. This explains why TRACER detected a similarity between excerpts from Psalms and Besa's Fragment 5/I/2. Consequently, the wrong source of the quotation may be identified. ${ }^{604}$

${ }^{603}$ Kuhn 1956b: 11.

604 The phrases "rescue me in your righteousness," "incline your ear to me," and "hasten to save me" are found in various Psalms. Therefore, in the taxonomy of text reuses from Section 2.2.1.1, they can be viewed as idiomatic text reuses since it is impossible to determine which Psalms were quoted. Moreover, because they are text reuses from within the Bible, they can be considered intra-biblical idiomatic text reuses. However, it should be noted that they are not intra-biblical intertexts per se, which are discussed in Subsection 2.1.2.1 because the source of the text reuse is not clear. 


\subsubsection{TR 9}

The next example (TR 9) is also a text reuse which TRACER detected, but TRACER displayed several source candidates of the text reuse.

$\underline{\text { Besa's Fragment 11/VIII/5 }}$

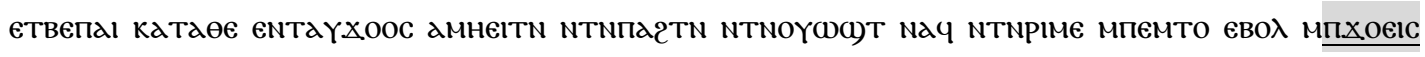

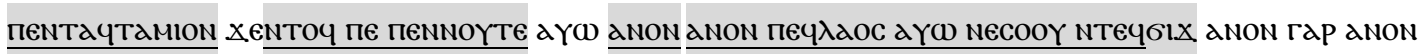

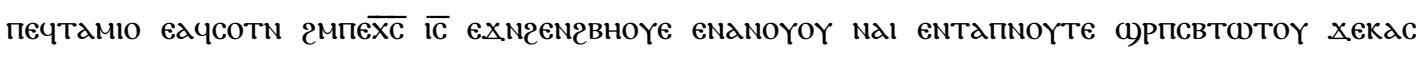
еNEMOOC)є 2PAI N2HTOY

Therefore, as it has been said, "Come, let us bow down and worship him and weep before the Lord our $\underline{\text { maker, }} \underline{\text { because he is our God and we are his people and the sheep of his hand }} .{ }^{605}$ For we are his creation, he having redeemed us in Christ Jesus for good works, which God has prepared before in order that we should walk in them."

TRACER source candidate: Ps 99:3 (100:3)

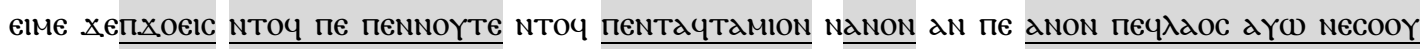

мпєчо२є

Know that the Lord, he is our God, our maker. It is not us. We are his people and the sheep of his herd.

${ }^{605}$ Ps 94:6-7 (95:6-7) according to Kuhn 1956b: 26.

${ }^{606}$ Eph 2:10 according to Kuhn 1956b: 26. The English translation is from Kuhn 1956b: 26. 
There is one QIP in Besa's Fragment 11/VIII/5: каTגeє entaYxooc ("according to what is said"). Therefore, it is likely a quotation. The text reuse seems to be a near-verbatim quotation in which Besa would have changed the word order. However, a text reuse detected by TRACER is not always an actual quotation or allusion, even if it looks like one (i.e., high similarity and shared morphs); this case is one such example.

In the target text, Besa mentions the Lord first but does not follow the order used in Ps 99:3 (100:3). In the phrase marked by пемтачтаміо (“our maker”) and an underline in the Ps 99:3 (100:3) text and English translation above in TR 9, he uses the term пеnтдyтdmon ("our maker"; lit. "the one who created us"). In Ps 99:3 (100:3), the psalmist uses a copulative sentence with a zero copula: NTO4 пептачтаміом ("he is our maker"; lit. "he is the one who created us")." However, Besa seemingly juxtaposed this phrase with nxoeıc ("the Lord"). In Ps 99:3 (100:3), пxoeıc ("the Lord") is juxtaposed with nточ "he," which is the subject of the copulative phrase nточ пє пемноүте ("he is our God"). It is followed by NaNON aN חє ("It is not us"). However, if this had been a quotation from Ps 99:3 (100:3), Besa would have only quoted anon "we." Rather, anon "we" in Besa may have been the left-dislocated subject of the copulative sentence if it had been a quotation from Ps 99:3 (100:3) ${ }^{607}$

${ }^{607}$ Usually, in Sahidic, this sentence can be expressed as anon aмnпєчגaoc using the reduced personal copula $\operatorname{an}(\mathrm{N})$ - for the first-person plural; see Layton 2011: 200. The form anON anoN- is also attested in Sahidic; see Funk 1991: 15. Neighboring dialects, such as Lycopolitan and Akhmimic, do not contain the reduced forms of the copulative pronominal subjects. See Miyagawa 2017: 416-21. Besa may exhibit slight Lycopolitan or Akhmimic influences. 


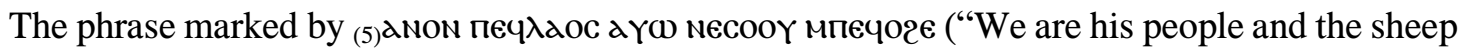
of his herd") and an underline in the Ps 99:3 (100:3) text and the English translation above in TR 9, the

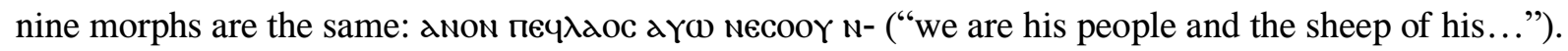
However, the last words are different in Besa's Fragment 11/VIII/5 and Ps 99:3 (100:3): Necoor мпєчогє ("the sheep of his herd") and NecooY NTє46ıx ("the sheep of his hand"), respectively. The contexts of both passages are similar. The authors were expressing that the Lord is their creator and that they are his people and his sheep. Thus, while many differences can be observed between the text reuse observed in Psalms and Besa's Fragment 11/VIII/5, the shared morphs and similar contexts entail that the two texts are very likely related. However, despite their similarity, Kuhn suggests that the quotation was from Ps 94:6-7 (95:6-7). The comparison below shows the basis for this assumption.

\subsubsection{TR 10}

The next text reuse was found by both Kuhn and TRACER.

Besa's Fragment 11/VIII/5

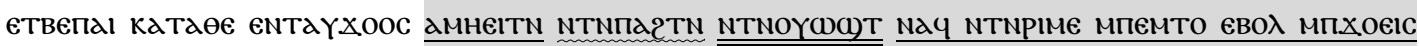

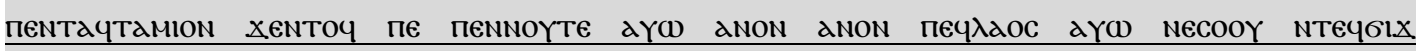

Therefore, according to what is said, come and bow down and worship him and weep before the Lord, the one who created us because he himself is our God and we ourselves are his people and the sheep of his hand. ${ }^{608}$

${ }^{608}$ Kuhn 1956b: 26. 
Source: Ps 94:6-7 (95:6-7)

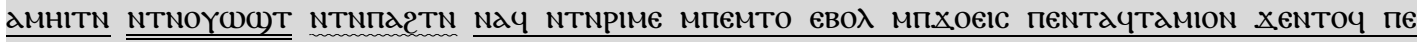

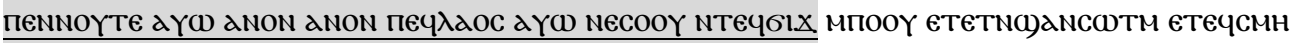

Come and worship and bow down to him and weep before the Lord, the one who created us because

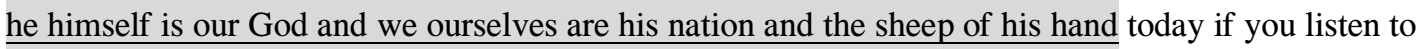
his voice. ${ }^{609}$

Although the positions of phrases NTNחג2TN ("and bow down") and NTNOY(N)T ("and worship") in the texts and English translations of Besa's Fragment 11/VIII/5 and Ps 94:6-7 (95:6-7) are reversed in the two texts, they share significantly more similarities than TR 9 detected by TRACER, which did not indicate Ps 94:6-7 (95:6-7) as the source of the quotation. All factors support the hypothesis that Besa quoted Ps 94:6-7 (95:6-7) and not Ps 99:3 (100:3). First, the quotation starts directly after the QIP KaTde€ ENTAYXOOC ("according to what it is said"). Second, there are fewer word order changes. Finally, the quotation from Ps 94:6-7 (95:6-7) contains more shared morphemes. Therefore, Kuhn's identification is more plausible than TRACER's suggestion.

\footnotetext{
${ }^{609}$ Author's own translation.
} 


\subsection{Frequent idiomatic text reuses identified by}

\section{TRACER}

As the 10 examples presented in Subsections 5.3.1-5.3.10 demonstrate, not every pair of similar texts presented as text reuse candidates by TRACER should be accepted at face value. Instead, researchers must determine whether the text reuse cases constitute direct quotations or coincidences. However, by searching more potential source texts, it is possible to identify which passage is most likely to be a source text.

Shenoute and Besa repeatedly used certain biblical idioms, which can be readily discerned as idiomatic text reuses. Table 23 shows idiomatic text reuses found by TRACER in between Shenoute's Canon 6 and the Psalms and between Besa's Letters and Sermons and the Psalms. рготе гнтч мпхоєіс "Fear the Lord" were the most frequent idiomatic quotation in Besa's Letters and Sermons and Shenoute's Canon 6 as seen in Table 23. 


\begin{tabular}{|c|c|c|c|c|c|}
\hline Translation & Original idiom & $\begin{array}{l}\text { Freq. in } \\
\text { Psalms }\end{array}$ & $\begin{array}{l}\text { Freq. in } \\
\text { Canon } 6\end{array}$ & $\begin{array}{l}\text { Freq. in } \\
\text { Besa }\end{array}$ & $\begin{array}{l}\text { Shared } \\
\text { morphs }\end{array}$ \\
\hline "Fear the Lord" & Рготе гнтч мпхоєІс & $11^{610}$ & $1^{611}$ & $6^{612}$ & 7 \\
\hline $\begin{array}{l}\text { "Evil in the place of } \\
\text { good" }\end{array}$ & $\begin{array}{l}\text { ¿єNпєеоO } \\
\text { N2єNпєTNANOYOY }\end{array}$ & $2^{613}$ & 0 & $4^{614}$ & 13 \\
\hline "Fear God" & Р2оте гнтч мпмоҮте & $2^{615}$ & $8^{616}$ & $18^{617}$ & 7 \\
\hline
\end{tabular}

${ }^{610}$ Ps 14:4 (15:4), $21: 24$ (22:23), 24:12 (24:12), $32: 8$ (33:8), 111:1 (112:1), 113:19 (114:8 Budge;

115:11), 113:21 (114:10 Budge; 115:13), 117:4 (118:4), 127:1 (128:1), 127:4 (128:4), and 134:20 (136:20).

${ }^{611}$ Then Am I Not Obliged, MONB.XM p. 344.

612 (1) Fragment 3/III/2, (2) Fragment 6/III/3, (3) Fragment 13/III/3, (4) Fragment 17/VII/1, (5)

Fragment 29/I/3, and (6) Fragment 32/V/7.

${ }^{613}$ Ps $34: 12$ and $37: 21$.

${ }^{614}$ (1) Fragment 22/I/9, (2) Fragment 27/VII/3, (3) Fragment 34/I/1, and (4) Fragment 34/II/7.

${ }^{615}$ Ps 54:20 (19 Budge; 55:19) and 65:16 (66:16).

616 (1) Then Am I Not Obliged, MONB.XM p. 344; (2) p. 347; (3) p. 463; (4) Remember O Brethren, MONB.YJ p. 47 and MONB.XV p. 70; (5) Is It Not Written, MONB.XM p. 177; (6) MONB.XF p. 231; (7) p. 239; and (8) MONB.XF p. 231 and MONB.XM p. 284.

${ }^{617}$ (1) Fragment 3/X/4, (2) Fragment 6/II/4, (3) Fragment 7/II/1, (4) Fragment 12/VI/1, (5) Fragment 12/VIII/4, (6) Fragment 12/XI/1, (7) Fragment 13/III/2, (8) Fragment 15/I/2, (9) Fragment 17/V/4, (10)

Fragment 19/I/1, (11) Fragment 20/I/3, (12) Fragment 23/I/1, (13) Fragment 23/V/6, (14) Fragment 24/III/4, (15) Fragment 30/IV/1, (16) Fragment 32/I/6, (17) Fragment 33/I/4, and (18) Fragment 34/ II/5. 


\begin{tabular}{|c|c|c|c|c|c|}
\hline "Before God" & мпємто єво $\lambda$ мпNоҮТЕ & $5^{618}$ & $4^{619}$ & $10^{620}$ & 7 \\
\hline $\begin{array}{ll}\text { who } & \text { work } \\
\text { lawlessness } & \end{array}$ & етргов етаNомIа & $14^{621}$ & $1^{622}$ & $7^{623}$ & 6 \\
\hline Before the Lord & мпємто єво $\lambda$ мпхоєІс & $8^{624}$ & $2^{625}$ & $8^{626}$ & 7 \\
\hline
\end{tabular}

Table 23: Most frequent idiomatic text reuse pairs between Canon 6, Besa, and Psalms.

${ }^{618}$ Ps 60:8 (7 Budge; 61:7), 67:4 (3 Budge; 66:3), 67:9 (8 Budge; 68:8; twice), and 113:7 (114:7).

${ }^{619}$ (1) He Who Sits Upon His Throne, MONB.XF p. 4; (2) Is It Not Written, MONB.XV p. 104; (3) Is It Not Written, MONB.XF p. 249; and (4) Is It Not Written, MONB.XF p. 271 and MONB.XM p. 283.

${ }^{620}$ (1) Fragment 20/I/2, (2) Fragment 20/II/5, (3) Fragment 21/I/1, (4) Fragment 26/IV/4, (5) Fragment 27/VIII/6, (6) Fragment 29/ III/2, (7-8) Fragment 33/I/4 (twice), (9) Fragment 33/II/2, and (10) Fragment 36/I/7.

${ }^{621}$ Ps 5:6 (5 Budge; 5:5), 6:9 (8 Budge; 6:8), 13:4 (14:4), 27:3 (28:3), 35:13 (12 Budge; 36:12), $52: 5$ (4 Budge; 53:4), 58:3 (2 Budge; 59:2), 58:6 (5 Budge; 59:5), 63:3 (2 Budge; 64:2), 91:8 (7 Budge; 92:7), $91: 10$ (9 Budge; 92:9), 93:4 (94:4), 93:16 (94:16), and 124:5 (125:5).

${ }^{622}$ Remember O Brethren, MONB.XV p. 72.

${ }^{623}$ (1) Fragment 11/VI/2, (2) Fragment 12/III/7, (3-4) Fragment 12/X/2 (twice), (5) Fragment 17/VI/6, (6) Fragment 24/IV/7, and (7) Fragment 27/II/4.

${ }^{624}$ Ps 94:6 (95:6), 95:13 (96:13), 96:5 (97:5; twice), 101:1 (0 = foreword Budge; 102:0), 108:14 (109:14), 108:15 (109:15), and 113:7 (114:7).

${ }^{625}$ He Who Sits Upon His Throne, MONB.XF p. 11 and Then Am I Not Obliged, MONB.XM p. 305.

${ }^{626}$ (1) Fragment 3/III/2, (2) Fragment 4/III/5, (3) Fragment 11/VIII/5, (4) Fragment 21/I/3, (5)

Fragment 24/I/3, (6) Fragment 35/I/2, (7) Fragment 36/I/9, and (8) Fragment 37/I/2. 
For example, рготе 2нтч мпхоєіс ("Fear the Lord") appears 11 times in the Psalms, once in Shenoute's Canon 6, and 6 times in Besa's Letters and Sermons. TRACER detected 11 text reuses containing рготе гнтч мпхоєıс ("Fear the Lord") between Shenoute's Canon 6 and the Psalms and 66 text reuses between Besa's Letters and Sermons and the Psalms. As such, most of the text reuse candidates found by TRACER are idiomatic text reuses. The most prominent examples are listed in Table 23 .

\subsection{Newly identified quotations}

In Section 5.4, all the quotations detected by TRACER and unknown to the previous studies are described. Below each set of Shenoute or Besa's quotation and source Psalm text, an information box is displayed. Each information box had the number of the Levenshtein Distance (LD), the QIP, the text reuse type (TR type), and the number of shared morphs (SM). ${ }^{627}$

The described TR type is based on TRACER's text reuse taxonomy discussed in Subsection 2.2.1.1 If there are differences between the quotation and the source text, the differences are noted. If the text reuse was a near-verbatim quotation or a paraphrase, a detailed description of morpheme alternation, morpheme order change, morpheme deletion, and morpheme insertion is provided. Spelling variants, such as the prenominal genitive marker before a bilabial sound ( $\left.\mathrm{M}^{-}\right)$and its spelling variant $(\mathrm{em}-)$, were ignored because they can mostly be attributed to each scribe's idiosyncrasies.

${ }^{627}$ For the Levenshtein Distance (LD), see the next subsection (Subsection 5.4.1). 


\subsubsection{Levenshtein Distance}

The Levenshtein Distance (LD) ${ }^{628}$ is frequently used in computer science to calculate the similarity between two texts. It is also known as "edit distance." The lower the LD, the more similar two texts are. Formally, the LD is defined as "the smallest number of insertions, deletions, and substitutions required to change one string or tree into another." ${ }^{\prime 629}$ This may involve several actions, such as adding a letter, deleting a letter, and replacing a letter with another. If addition and deletion occur at the same place within a given text, they are treated as a replacement. For example, the LD between мтачсотм and аүсотмч is five because there are two alternations (the first from $\varphi$ to $Y$ and the second from $\omega$ to o), two deletions ( $\mathrm{N}$ and $\mathrm{T}$ ), and one addition (४).

The LD has been used to detect plagiarism in essays. In this study, it was used to evaluate text reuse candidates in terms of the modifications made by Shenoute and Besa to a quotation. There are other ways to calculate the similarity between two texts, including extended versions of the LD such as the Damerau-Levenshtein Distance. ${ }^{630}$ However, the LD was chosen because it is the most frequently used method in text reuse detection, plagiarism checking, and spell checking. Thus, there are many

\footnotetext{
${ }^{628}$ The LD is named after Vladimir Iosifovich Levenshtein (1935-2017).

${ }^{629}$ Black 1999.

${ }^{630}$ Named after Frederick J. Damerau (1931-2009) and Levenshtein.
} 
available tools for calculating the LD, such as PLANETCALC's online LD calculator, which was used to calculate the LD in this study because of its easiness of use. ${ }^{631}$

\subsubsection{New Psalm quotations found in Besa's Letters and}

\section{Sermons}

\subsubsection{Quotation B1}

In Fragment 4, Besa told his disciples to avoid an evil way of life. In the first paragraph of Fragment 4, TRACER identified several reuse candidates that had not been described in previous studies.

\section{Besa's Fragment 4/I/2 (On Repentance)}

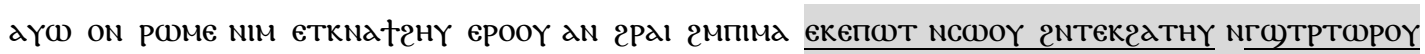

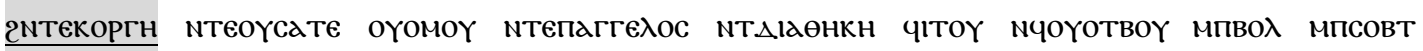

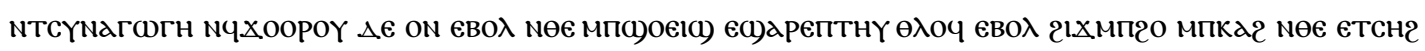

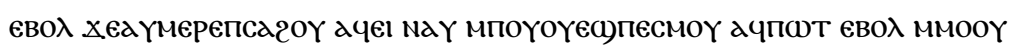

And all men from whom you will get no gain in this place, you will pursue with your whirlwind, and vex with your wrath, and a fire shall devour them. The angel of the covenant shall take them and remove them outside the wall of the community, and shall moreover disperse them, even as the dust

${ }^{631}$ https://planetcalc.com/1721, last accessed on November 21, 2021. 
which the wind scatters upon the face of the earth, as it is written, "Forasmuch as they loved the curse, it came upon them; they did not desire the blessing, it fled from them.",632

\section{Source: Ps 82:16 (15 Budge; 83:15)}

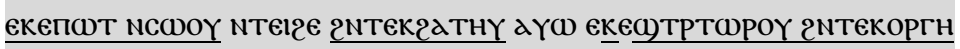

you will pursue them in this way with your tempest, and with your wrath dismay them.

LD: 15, QIPs: none, TR type: near-verbatim quotation [alternation: 1 (Conjunctive $\mathrm{N}^{-} \rightarrow$ Future III or Optative $\left.\epsilon^{-} . . .-6-\right)$, deletions: 3 (N-Tel-2€)], SM: 14

There is no QIP in Besa's Fragment 4/I/2, which quotes Ps 82:16 (15 Budge; 83:15). Kuhn did not identify this as a quotation. The auxiliary verb was changed in the target text. Besa deleted the prepositional phrase NTel2 ("in this manner"). The target text translates to, "And all men from whom you will get no gain in this place, you will pursue with your whirlwind, and vex with your wrath, and a

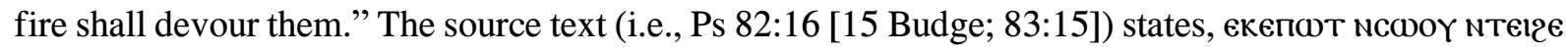

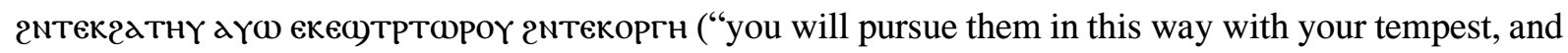
with your wrath dismay them"). The type of text reuse is a near-verbatim quotation with an alternation of verbal auxiliary from a Future III or Optative circumflex $\epsilon^{-} . . .-\epsilon^{-}$("shall") to a Conjunctive marker $\mathrm{N}$ - ( "and"; the same tense, mood, and aspect as the previous clause). In addition, it contains a deletion

${ }^{632}$ The last quotation in this passage from Ps 108:17 (109:17) was found by Kuhn 1956b: 9. The English translation is from Kuhn 1956b: 9. 
of a $\mathrm{y} \omega$ and a phonological alternation of the masculine second-person subject marker from $\mathrm{k}$ - to $\mathrm{r}$ - after a nasal consonant $\mathrm{N}$. This pair of texts shares 13 morphs, ${ }^{633}$ and one morph ( $\left.г: \mathrm{k}\right)$ is a morphophonological variation.

\subsubsection{Quotation B2}

The second quotation from Psalms that TRACER identified was Ps 20:10 (Budge 9; 21:9), which appears in Besa 4/I/2.

Besa's Fragment 4/I/2 (On Repentance)

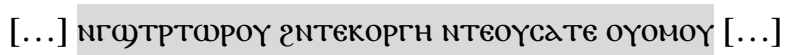

$[\ldots]$ and vex with your wrath, and a fire shall devour them, $[\ldots]^{634}$

Source: Ps 20:10 (9 Budge; 21:9)

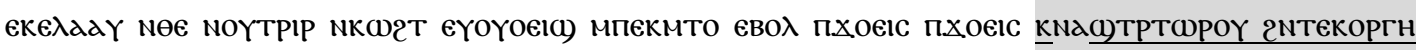
NTEOYсате OYOMOY

You make anyone like a fire oven at a time of your presence, O Lord, O Lord, you will disturb them in your wrath and a fire will devour them.

LD: 2, QIPs: none, TR type: near-verbatim quotation [alternation: 1 (Future -Nd- $\rightarrow$ Conjunctive $\mathrm{N}-)$ ], SM: 11

${ }^{633}$ Future III or Optative circumflex $6-$ PRONOUN- $€-$ is counted as a single morph.

${ }^{634}$ Kuhn 1956b: 9. 
This text reuse appears immediately after Quotation 1. There are no QIPs in Besa's quoted text, and Kuhn did not identify the text reuse as a quotation. The type of text reuse is a near-verbatim quotation in which the Future marker $\mathrm{Na}$ - is deleted and the Conjunctive marker $\mathrm{N}$ - is added. In addition, the masculine second-person singular subject marker $\mathrm{K}$ - is voiced after the nasal consonant $\mathrm{N}-$ as $\mathrm{r}-$. This pair of texts shared 11 morphs, but -г- (“you"; masculine singular) after a nasal sound and -к-, ("you"; masculine singular) were two elements of a single morphophonological variation. The clause мго)тртороү ("and vex with your wrath") is the beginning of the quotation from Ps 20:10 (9 Budge; 21:9) and the end of the quotation from Ps 82:16 (15 Budge; 83:15), which was discussed above in Quotation B1. Figure 25 shows the pivotal role of мготртороү 2мтекоргн in the seamless sequence of the two quotations from Psalms:

екепШт NCWOY 2NTEK2dTHY

you will pursue with your whirlwind,

$$
\text { Nго)тртФроҮ 2NTекоргн }
$$

and vex with your wrath,
NTEOYCATE OYOMOY

and a fire shall devour them.

Quotation from Ps 82:16 (15 Budge; 83:15)

Quotation from Ps 20:10 (9 Budge; 21:9)

Figure 25: Structure of two overlapping quotations from Ps 82:16 (15 Budge; 83:15) and Ps 20:10 (9 Budge;

$$
\text { 21:9) in Besa's Fragment 4/I/2. }
$$

As shown in Figure 25, мго)тртюро (“and vex") plays a key role in both quoted texts. Besa skillfully combined two quotations by using a similar phrase.

The continuation of Quotation B1 also contains an allusion and a quotation without a QIP, which TRACER detected for the first time, and another quotation signaled by a QIP: мөє єтснг єво х хе- ("as it is written"), which Kuhn identified. 


\subsubsection{Allusions to Ex 23:20-22}

In addition, the phrase пагге入ос NT $\triangle$ Iдөнкн ("the Angel of the Covenant") in Besa's Fragment 4/I/2 is not found in the Coptic Bible but may refer to the angel that appears in Ex 23:20-22:

$\underline{\text { Besa's Fragment 4/I/2 (On Repentance) }}$

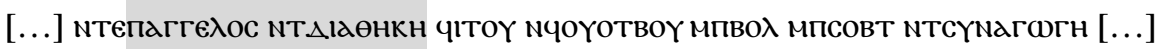

$[\ldots]$ and the angel of the covenant shall take them and remove them outside the wall of the community, $[\ldots] .{ }^{635}$

Source: Ex 23:20-22

And look, I am sending my angel in front of you in order to guard you on the way in order to bring you into the land that I prepared for you. Mind yourself, and listen to him, and do not disobey him. For he shall not hold you in undue awe, for my name is upon him. If by paying attention you listen to my voice and do all that I tell you, I will be an enemy to your enemies and will resist those who resist you. For my angel will go, leading you, and will bring you in to the Amorrite and Chettite and Pherezite and Chananite and Gergesite and Heuite and Iebousite, and I will destroy them. ${ }^{636}$

This is an allusion to the Book of Exodus, not Psalms. This was not found by TRACER, but by the present author manually. In this passage, Yahweh promises Moses that he will send an angel to protect the Israelites and destroy the enemies who block their invasion of the land of Canaan from Egypt.

${ }^{635}$ Kuhn 1956b: 9.

${ }^{636}$ NETS, Ex 2:20-23. 
Thus, Besa used figurative language in the form of a quotation from Ps 1:4 to allude to Ex 23:20-22: according to Besa's Fragment 4/I/2, the angel of the Covenant removes his enemies from his monastic community, physically out of the wall of the monastery.

\subsubsection{Quotation B3}

After the allusion to Ex 23:20-22, there is another near-verbatim quotation from Ps 1:4, which was not identified by Kuhn.

Besa's Fragment 4/I/2 (On Repentance)

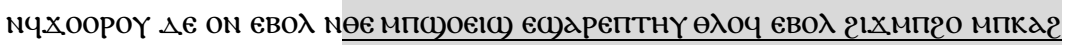

$[\ldots]$ even as the dust which the wind scatters upon the face of the earth, $[\ldots]^{637}$

Source: Ps 1:4

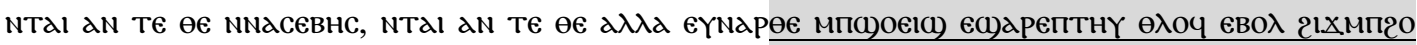

$\underline{\text { MחKג2 }}$

This is not like the impious. This is not so, but they will be like the dust which the wind scatters upon the face of the earth.

LD: 0, QIPs: none, TR type: verbatim quotation but with different grammatical function, SM: 18

${ }^{637}$ Kuhn 1956b: 9. 
In Besa's Fragment 4/I/2, Besa deleted the circumstantial converter, the third-person plural pronoun, the Future marker, and the prenominal state of the verb eүNap- ("but they will be ..."). Moreover, he positioned the preposition $\mathrm{N}$ - such that the verbal phrase became a prepositional phrase. When Besa introduces a quotation by $\Theta \epsilon$, this quotation seems to be verbatim, but the grammatical functions are different; one is verbalized by the light verb p- ("do") and the other is in a prepositional phrase in which Besa uses the metaphor of dust, which a wind blows away from the earth, for his enemies, which the Lord will remove from the community, like the enemies of the Israelites whom the angel of the covenant destroyed. $\triangle €$ oN may be a QIP; these two discourse particles are not used as QIPs. In Exodus, the God of Israel says that he will send an angel of the Covenant to protect the people of Israel and wipe out its enemies, such as the Amorites, Hittites, and Canaanites. Thus, Besa equates evil people with these enemies, and this section is replete with text reuses.

\subsubsection{A quotation from Ps 108:17 (109:17) found by Kuhn and}

\section{TRACER in Besa's Fragment 4/I/2}

Finally, the passage concludes with a quotation from Ps 108:17 (109:17), which was identified by Kuhn and TRACER after the quotation from Ps 1:4.

Besa's Fragment 4/I/2 (On Repentance)

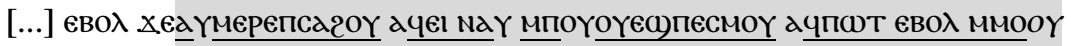


$[\ldots]$ because "Forasmuch as they loved the curse, it came upon them; they did not desire the blessing, it fled from them. ${ }^{.638}$

Source: Ps 108:17 (109:17)

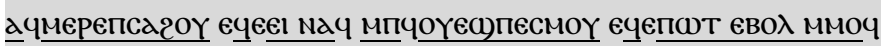

He loved the curse. It shall come to him. He did not want the blessing. It shall flee from him. ${ }^{639}$

LD: 10, QIPs: none, TR type: near-verbatim quotation [alternation: 6 (masculine third-person singular $-\mathrm{q}^{-} \rightarrow$ third-person plural $-(\mathrm{o}) \Upsilon^{-}$, twice; masculine third-person singular $-\mathrm{q} \rightarrow$ third-person plural -o\}, twice; Perfect I or Past a- $\rightarrow$ Future III or Optative e-...---, twice)], SM: 16

The main differences between the target text (Besa's Fragment 4/I/2) and the source text (Ps 108:17 [109:17]) are a change in the tense-aspect-mood marker from the Future III or Optative marker €-...-e- to the Perfect I or Past marker $\mathrm{d}$ - and a change in person from the masculine third-person singular to the third-person plural. Besa connected this quotation to Quotation B3 and supported the metaphor of dust to signify the easy removal of enemies from the community through his use of the quotation from Ps 108:17 (109:17). Furthermore, this section contains four quotations from the Psalms and one possible allusion to Exodus:

${ }^{638}$ Kuhn 1956b: 9.

${ }^{639}$ Author's own translation. 


\section{Besa's Fragment 4/I/2 (On Repentance)}

"And all men from whom you will get no gain in this place, you will pursue with your whirlwind and vex with your wrath" (Ps 82:16 [83:15]); “with your wrath" (shared by Ps 82:16 [83:15] and Ps 20:10 [21:9]); "and a fire shall devour them" (namely, bad monks and nuns; Ps 20:10 [21:9]); "The angel of the covenant shall take them and remove them outside the wall of the community, and shall moreover disperse them," (Ex 23:20-22) even as "the dust which the wind scatters upon the face of the earth" (Ps.1:4) and as itis written, "Forasmuch as they loved the curse, it came upon them; they did not desire the blessing, it fled from them" (Ps 108:17 [109:17]). ${ }^{640}$

Since TRACER found three prior text reuses, the QIP may also modify the three clauses. The part between the near-verbatim quotations from Ps 20:10 (9 Budge; 21:9) and Ps 1:4 is a probable allusion to Ex 23:20-23.

\subsubsection{Quotation B4}

The next text reuse appears in Fragment 7 (On Eschewing Evil) and is likely a quotation from Ps 5:7 (6 Budge; 5:6). Kuhn did not previously identify this quotation.

\section{Besa's Fragment 7/III/2 (On Eschewing Evil)}

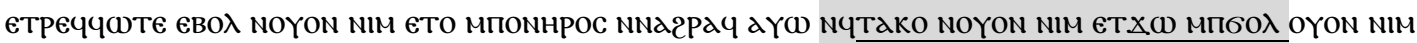

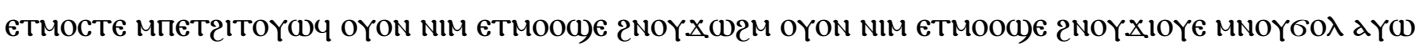

${ }^{640}$ Kuhn 1956b: 9. The quotation references and detailed explanations in parentheses were added by the present author. 


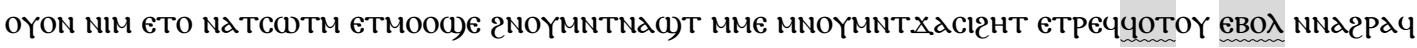

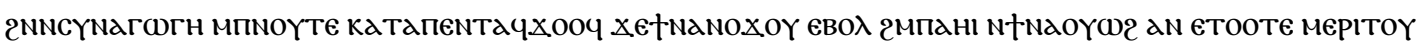
tNATAKo $\lambda \in$ nNETO NATCOTM

so as to wipe out everyone who is wicked before him and destroy everyone who lies, everyone who hates his neighbour, everyone who walks in defilement, everyone who walks in thieving and lying, and everyone who is disobedient, who walks in stubbornness and pride, that he may wipe them out before him in the communities of God, according to what has been said, "I will cast them out of my house, I will not love them any more, ${ }^{641}$ and I will destroy those who are disobedient.",642

\section{Source: Ps 5:7 (6 Budge; 5:6)}

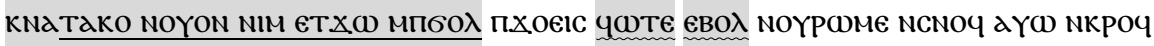

You will destroy everyone who lies. The Lord wipes out a bloody and guileful man.

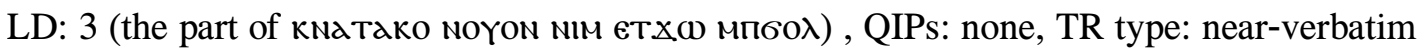
quotation [alternation: 2 (masculine second-person singular $\kappa-\rightarrow$ masculine third-person singular $\varphi_{-}$; Future -Na- $\rightarrow$ Conjunctive N-)], SM: 11

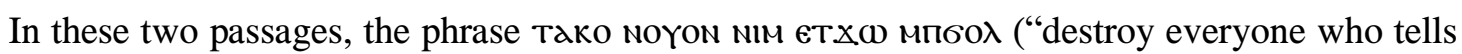
the lie") is shared by Besa's Fragment 7/III/2 and Ps 5:7 (6 Budge; 5:6). Nine morphs were identical.

${ }^{641}$ Hos 9:15 according to Kuhn 1956b: 17.

${ }^{642}$ Kuhn 1956b: 17. 
However, Besa's phrase does not have a QIP. Ps 5:7 (6 Budge; 5:6) uses the masculine second-person pronoun to denote God and the Future tense marker before the verb phrase, while Besa uses the

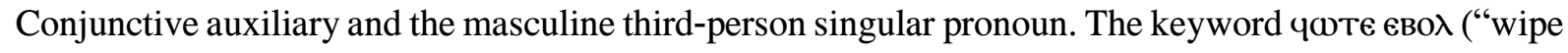
out") is also shared by both passages: status constructus чот- ("wipe") in Fragment 7/III/2 and status absolutus ч๗те ("wipe") in Ps 5:7 (6 Budge; 5:6). After the verbatim quotation, there are many

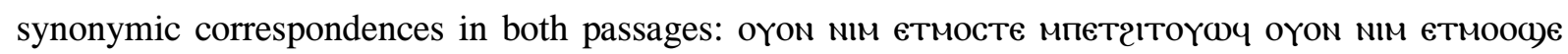
2NOYХW

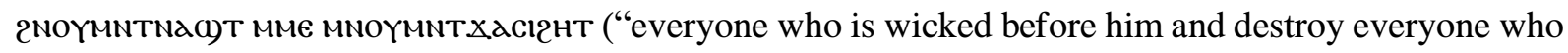
lies, everyone who hates his neighbor, everyone who walks in defilement, everyone who walks in thieving and lying, and everyone who is disobedient, who walks in stubbornness and pride") in Besa's Fragment 7/III/2 and оүрФме nсnоч aүळ nкроч (“a bloody and guileful man") in Ps 5:7 (6 Budge; 5:6). Thus, the context of the source and target texts are similar: God wipes out liars and evildoers. However, in Fragment 7/III/2, the context is more specific: casting out disobedient monks and nuns from Besa's community. The phrase "destroy everyone who lies" could be idiomatic text reuse, but due to the significant number of shared morphs and the similar context of these two passages, it would be reasonable to conclude that this text reuse candidate is a quotation that Kuhn did not discover.

\title{
5.4.2.7. Quotation B5
}

The next new quotation is from Fragment 11 (To an Erring Monk).

\author{
Besa's Fragment 11/II/1 (To an Erring Monk)
}




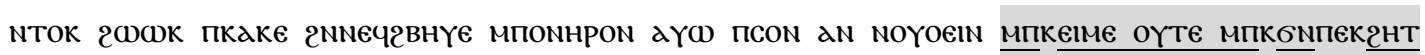

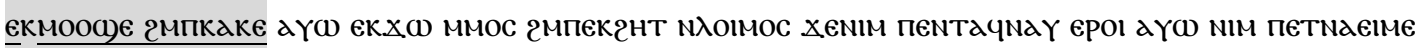
ePOI ENE†EIPE MMOOY NXIOYe

You, indeed, are darkness with its evil works and not a brother of light. You did not know nor did you learn wisdom, walking in the dark and saying in your pestilent heart, "Who has seen me, and who shall know concerning me of the things which I do stealthily?"643

Source: Ps 81:5 (82:5)

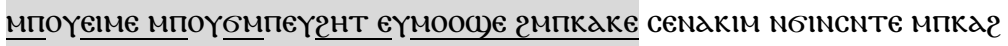

They did not know nor did they learn wisdom, walking in the darkness. The foundations of the earth will move.

LD: 13, QIPs: none, TR type: near-verbatim quotation [alternation 4 (third-person plural oY$\rightarrow$ masculine second-person singular $\kappa-$, thrice; masculine singular possessive article with thirdperson plural possessor поү- $\rightarrow$ masculine singular possessive article with second-person singular possessor пек-)], SM: 11

Fragment $11 / \mathrm{II} / 1$ is a letter to a monk who broke the rules of the monastic community, such as stealing loaves of offering. Besa condemns the monk's disobedience and exhorts him to avoid evil acts, according to his monastic discipline. Ps 81:5 (82:5) describes the behavior of evildoers who did not find

${ }^{643}$ Cf. Is 29.15 according to Kuhn 1956b: 21. The English translation is from Kuhn 1956b: 21. 
their heart and walked in darkness. As such, by shifting from the third-person plural to the masculine second-person singular, Besa condemns the behavior of an enemy in his monastic community by targeting this Psalms passage at them.

\subsubsection{Discussion of newly identified Psalms quotations in}

\section{Besa's Letters and Sermons}

Although Kuhn's accuracy in detecting quotations is very high compared to, e.g., Amélineau in his edition of Shenoute's works, TRACER discovered five additional quotations. This is particularly noteworthy because Psalms are among the biblical books most frequently quoted in Late Antique Christian literature and quotations should be comparatively easy to detect.

However, one of the challenges associated with TRACER is that it is time-consuming for scholars to prepare linguistically tagged Coptic texts that are suitable for use with this tool. This issue could potentially be resolved by introducing linguistically parsed corpora from digital humanities projects in Coptic studies, such as Coptic SCRIPTORIUM. In addition, scholars who lack sufficient training in advanced computer technologies may find TRACER difficult to use because it does not have a graphical user interface. It can only be operated using a command line interface, which relies on technological skills and experience with commands. By contrast, if a graphical or visual user interface was introduced for TRACER, users would be able to use the program with relative ease. In short, the use of TRACER is associated with challenges that the field of digital humanities for Coptic studies must overcome. 


\subsubsection{New Psalm quotations identified in Shenoute' $s$}

\section{Canon 6}

This subsection describes text reuses of the Psalms that TRACER identified for the first time in Shenoute's Canon 6. An analysis of previous research on Canon 6 showed that text reuse detection accuracy varies widely across different scholars; for instance, the accuracy achieved by Wiesmann based on the Coptic text edited by Leipoldt and Crum $^{644}$ was higher than that of Amélineau. ${ }^{645}$ However, while Amélineau and Wiesmann covered a large part of Canon 6, they excluded some parts from their studies. Some of the missing parts of Canon 6 can be supplemented by two occasional papers by Young that provide Young's transcription of pages containing Canon $6 .{ }^{646}$ or a book on monastic rules by Layton. ${ }^{647}$ Nevertheless, the small part of the pages whose existence was confirmed by Emmel remain unpublished, or only their texts were published but biblical text reuses were not studied ${ }^{648}$ Recently, Behlmer discussed quotations that Amélineau did not identify in He Who Sits Upon His Throne ${ }^{649}$ The following text reuses, all of which are quotations, were not identified in the abovementioned studies.

\footnotetext{
${ }^{644}$ Wiesmann 1931 and 1936, Leipoldt and Crum 1906 and 1913.

${ }^{645}$ Amélineau 1907 and 1914.

${ }^{646}$ Young 2000 and 2002.

${ }^{647}$ Layton 2014.

${ }^{648}$ Mounir 1916.

${ }^{649}$ Behlmer 2017.
} 


\subsubsection{He Who Sits Upon His Throne}

\subsection{Quotation S1}

Shenoute's Canon 6, He Who Sits Upon His Throne, MONB.XF p. $2^{650}$

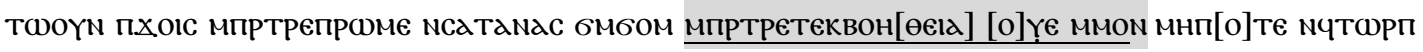

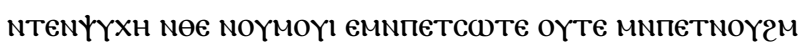

"Rise, o Lord, do not allow the satanic man to prevail. ${ }^{651}$ Do not let your help [be] far from us, so that he may not snatch our soul like a lion, without there being a saviour or a rescuer. ${ }^{652}$

Source: Ps 21:20 (19 Budge; 22:19)

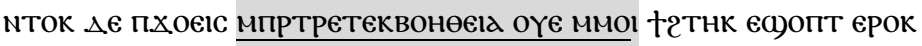

But you are the Lord, do not let your help be far from me! Take heed to accept me!

LD: 1, QIPs: none, TR type: near-verbatim quotation [alternation 1 (first-person singular personal suffix $-1 \rightarrow$ first-person plural personal suffix $-\mathrm{N})$ ], SM: 6

${ }^{650}$ Amélineau 1914: 286-87.

651 "Rise ... prevail" is a quotation from Ps 9:19a, according to Behlmer 2017: 324.

${ }^{652}$ Behlmer 2017: 324. 
The above passage from He Who Sits Upon His Throne does not contain a QIP. The underlined section in Shenoute's Canon 6, He Who Sits Upon His Throne, MONB.XF p. 2 and Ps 21:20 (Budge $19 ; 22: 19)$ are very similar, except for the personal suffixes in the pre-pronominal object preposition MMo-. Shenoute uses first-person plural, while Ps 21:20 (Budge 19; 22:19) uses first-person singular. Thus, this quotation contains an alternation of the grammatical person. In the process of recontextualizing the Psalms passage, Shenoute changed the person from the first-person singular to plural because he entreats God for help in He Who Sits Upon His Throne, not only for himself but also for the monks and nuns who stood by his side in solidarity against the satanic man. ${ }^{653}$

In the original context of this Psalm, David is in danger of being executed at Ziklag. David's entire crisis and prayer for deliverance in this Psalm continue to echo his experience of being chased by Saul. Shenoute recontextualized the context of this Psalm to entreat God for help with a satanic person at his monastery; in the above passage, "satanic" was an insertion made by Shenoute. MONB.XF p.2 also contains another quotation from Psalms in which Shenoute once again recontextualizes the passage through skillful rhetoric. Amélineau did not identify this quotation, but Behlmer did in her latest study from $2017 .{ }^{654}$

\footnotetext{
${ }^{653}$ Amélineau 1914: 287.

${ }^{654}$ Behlmer 2017: 324.
} 


\subsection{Quotation S2}

The next quotation was also identified by both Behlmer in 2017 and the first TRACER processing in 2016.

Shenoute's Canon 6, He Who Sits Upon His Throne, MONB.XF p $2^{655}$

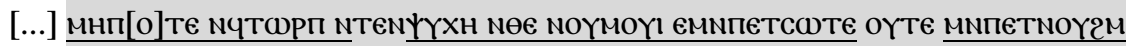

$[\ldots]$ so that he may not snatch our soul like a lion, without there being a saviour or a rescuer. ${ }^{656}$

Source: Ps 7:3 (2 Budge; 7:2)

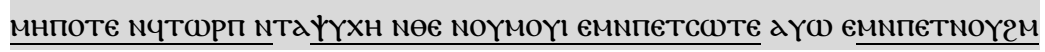

$\underline{\text { so that he may not snatch my soul like a lion, without there being a saviour and rescuer }} .{ }^{657}$

LD: 8, QIPs: none, TR type: near-verbatim quotation [alternation 2 (feminine singular possessive article with first-person singular possessor $\mathrm{Td}-\rightarrow$ feminine singular possessive article with first-person plural possessor TeN-; negative conjunction оүте $\rightarrow$ conjunction $a \gamma(\omega)$; deletion of the circumstantial converter e- in емNпетNOY2M], SM: 21

\footnotetext{
${ }^{655}$ Amélineau 1914: 287.

${ }^{656}$ Behlmer 2017: 324.

${ }^{657}$ I adjusted Behlmer 2017's translation to this Psalms passage and modified it.
} 
Amélineau published this portion of He Who Sits Upon His Throne with quotations that he found. ${ }^{658}$ Behlmer identified additional quotations in the first paragraphs of this work. ${ }^{659}$ There is no QIP in this passage by Shenoute. The two excerpts share 21 morphs. Shenoute changed the first-person singular (possessor) feminine singular (possessee) possessive article Td ("my") in Td- $ү \gamma \times$ ("my soul”) in Ps 7:3 (2 Budge; 7:2) into TeNYYXH "our soul," the first-person plural (possessor) feminine singular (possessee) possessive article. In addition, Shenoute changed the conjunction a $\gamma \omega$ ("and") to another conjunction orte ("nor"). It is possible that Shenoute opted to change the grammatical person from first-person singular to plural because it was not only Shenoute himself but also other monks and nuns who suffered evildoing at the hands of the satanic man.

\subsection{Quotation S3}

Shenoute's Canon 6, He Who Sits Upon His Throne, MONB.XF p. $2^{660}$

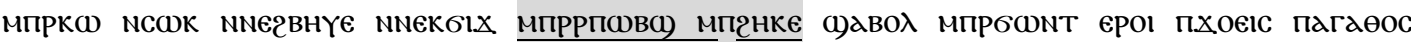

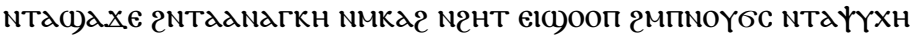

Do not renounce the works of your hands. Do not forget the poor utterly. Do not be angry with me, O Lord, O the Goodness, and I will speak in my necessity of affliction, when I am in the indignation of my soul.

${ }^{658}$ Amélineau 1914: 287ff.

${ }^{659}$ Behlmer 2017.

660 Amélineau 1914: 287. 


\section{Source: Ps 9:33 (32 Budge; 10:12)}

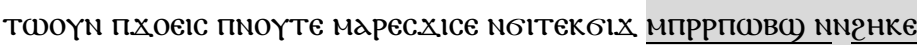

Arise, O Lord, God, let it be high, namely your hand. Do not forget the poor.

LD:3, QIPs: none, TR type: near-verbatim quotation [alternation 2 (accusative preposition $\mathrm{N}^{-}$

$\rightarrow$ post-posed nominative preposition $\mathrm{NGl}^{-}$; plural definite article $\mathrm{N}^{-} \rightarrow$ masculine singular definite article ח-)], SM: 5

On p. 2 of MONB.XF, Shenoute entreats God to not renounce his creatures, which was likely a reference to Shenoute and his monks and nuns. He also asks God to not forget the poor-again, a reference to Shenoute himself. The sentence before this quotation, namely мпрко мсбк мNє2внүє NNekolx, is a quotation from Ps 137:8 (138:8). This was not found by Amélineau or TRACER, but it was identified by Behlmer. ${ }^{661}$

It is possible that the morphs NeKGlx ("your hands") from Ps 137:8 (138:8) inspired the next quotation from Ps 9:33 (Budge 32; 10:12), as both Psalms texts share the morphs, although the possessive articles of the masculine second-person singular possessor differ in the grammatical numbers of the possessee (NeK- "your" in Ps 137:8 [138:8] vs. Tek- "your" in Ps 9:33 [Budge 32; 10:12]), attached to Gıx ("hand"). The morphs N/Tek6ıx ("your hand" or "your hands") is overlapped by two quotations

${ }^{661}$ Behlmer 2017: 324-25. 
from Ps 9:33 (32 Budge; 10:12) and Ps 73:19 (74:19). Shenoute seamlessly combines these two quotations from the Psalms with the pivotal phrase N/Tekolx ("your hand" or "your hands").

There is another possible source text for Quotation S3; TRACER found another text reuse candidate for this sentence in MONB.XF p. 2.

Shenoute's Canon 6, He Who Sits Upon His Throne, MONB.XF p. 2

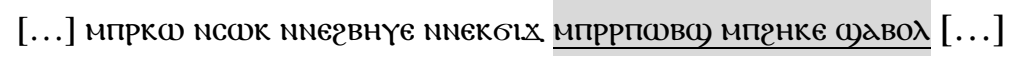

[...] Do not renounce the works of your hands. Do not forget the poor utterly $[\ldots]$

Source candidate: Ps 73:19(74:19)

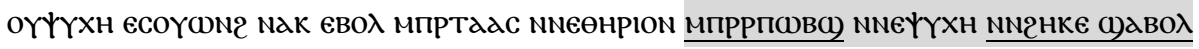

Do not give a soul which appears to you to the beasts. Do not forget the souls of the poor utterly.

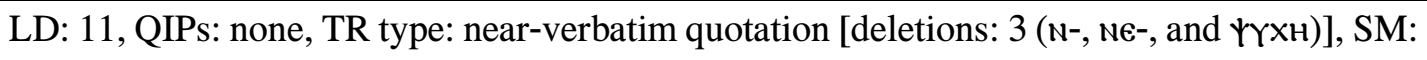

7

TRACER suggested Ps 73:19 (74:19) as a source text for the passage from MONB.XF, p. 2.

The target and source texts share eight morphs. However, the object of the compound verb, рпФво) ("forget") is different; this is мпгнке ("the poor") in Shenoute's Canon 6 and NмеYYXн nм2нке ("the souls of the poor") in Ps 73:19 (74:19). The difference between the two sentences' objects and the seamless flow of the quotations with the pivotal morphs $\mathrm{N} / \mathrm{Tek \sigma lx}$ ("your hand" or "your hands") supports the claim that the source text of this quotation is likely Ps 9:33 (32 Budge; 10:12). 


\subsection{Quotation S4}

The next example is possibly a new quotation. The passage is attested in two codices: MONB.XF and MONB.YJ.

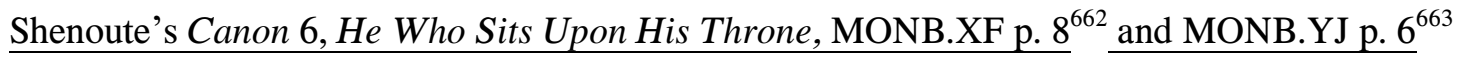

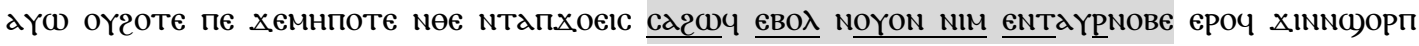

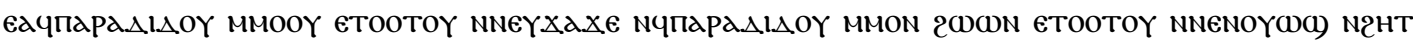
$\operatorname{e\theta oo\gamma }^{664}[\ldots]$

And it is a fear that, as the Lord has removed himself from whoever has sinned against him from the beginning, having delivered them into the hands of their enemies, he does not deliver also us to our evil desires of heart $[\ldots]$

Source: Ps 6:9 (8 Budge; 6:8)

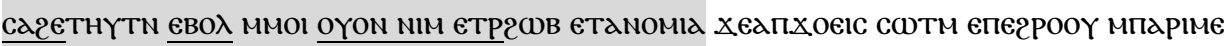

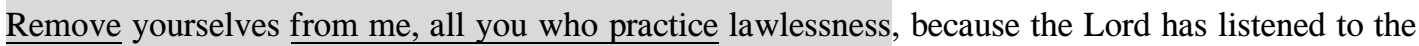
voice of my weeping.

\footnotetext{
${ }^{662}$ Amélineau 1914: 291-93.

${ }^{663}$ Amélineau 1914: 290-94.

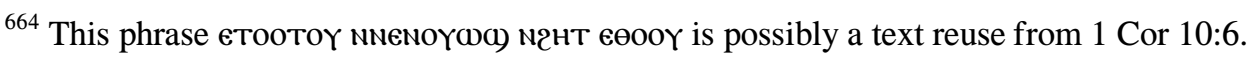


LD: 23, QIPs: none, TR type: near-verbatim quotation [alternations: 2 (second-person plural - тнҮтN $\rightarrow$ masculine third-person singular -ฯ; substitution of a phrase with a synonymous word $20 \mathrm{~B}$ етамоміа $\rightarrow$ NOBє), insertions: 3 (а-, $\Upsilon^{-}$, and N-), deletions: 2 (ммо-ı)], SM: 6

It is extremely difficult to judge whether this example is a quotation. Shenoute uses the prepronominal state of the verb cazco- ("remove") and masculine third-person singular object - 4 (“himself”), while Ps 6:9 (8 Budge; 6:8) uses the prenominal state with second-person plural suffixal pronoun cג一єтнүтN ("remove yourselves"). In Ps 6:9 (8 Budge; 6:8), there is an object-marking preposition with the first-person singular mmol ("me"), but the passage from Shenoute does not contain this preposition. After oYon NIm, both the passage by Shenoute and Ps 6:9 (8 Budge; 6:8) contain a relative clause. The passage by Shenoute uses a full relative clause with the resumptive subject pronoun entaYpnoвe ("who sinned"), while Ps 6:9 (8 Budge; 6:8) uses a relative clause without a subject

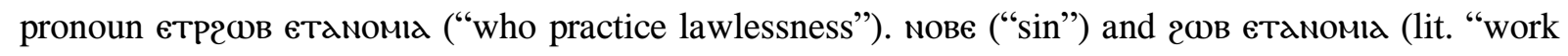
for the lawlessness") are in synonymic relation. Thus, this text reuse candidate contains several elements of the quotation, but there is insufficient evidence to justify the argument that it represents an exact quotation. Consequently, Shenoute's clause may be coincidentally similar to Ps 6:9 (8 Budge; 6:8) or constitutes a case of idiomatic text reuse.

\subsubsection{Remember, $O$ Brethren}

Of the works in Canon 6, Remember, O Brethren has the second-fewest pages because most of it is still missing. TRACER found one text reuse candidate between this work and the Psalms that had 
not been identified in previous studies. This is perhaps unsurprising since it appears in unpublished pages of Remember, $O$ Brethren.

\subsection{Quotation S5}

Shenoute's Canon 6, Remember, O Brethren, MONB.YJ pp. 40-41

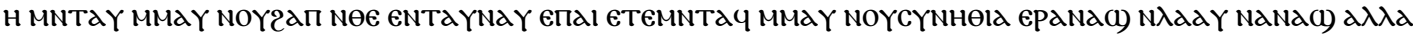

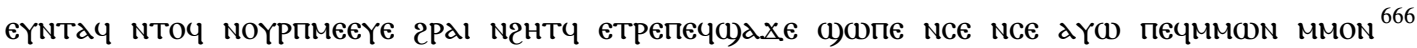

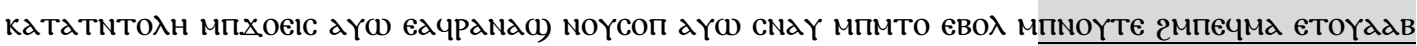

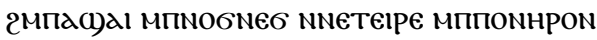

Or they do not have a judgment as they saw this one who does not have a habit to swear any oath, but who is aware that his speech should be yes 'yes' and his no (to be) 'no' according to the command of the Lord, while he has sworn once or twice before God in his holy place from the magnitude of reproach for those who do evil.

Source: Ps 67:6 (5 Budge; 68:5)

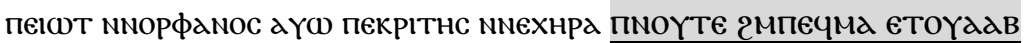

the father of the orphans and the vindicator of the widows, God in his holy place

LD: 0, QIPs: none, TR type: verbatim quotation, SM: 7

${ }^{665}$ Unpublished.

${ }^{666}$ Cf. Mt 5:37. 
The phrase пмоүте гмпмд єтоүадв ("God who is in his holy place") is not attested in Sahidic Bible 2.0, except in Ps 67:6 (5 Budge; 68:5). Ps 67 (68) is about the glory of the Kingdom of Israel: the promised future victory of God and his righteousness against evil, ${ }^{667}$ praise to God, ${ }^{668}$ miracles with natural disasters and harshness in Israel's procession to Canaan, ${ }^{669}$ glories of the temple, ${ }^{670}$ procession with water, ${ }^{671}$ and again praise to God. ${ }^{672}$ In Ps 67:5-7 (4-6 Budge; 68:4-6), the Psalmist mentions that God, who is in his holy place, is the father of the fatherless child and the protector of a widow, as God led the rebellious house of Israel (composed of prisoners in Egypt) through the desert to find prosperity in Canaan. By referencing this quotation from Ps.67:6 (5 Budge; 68:5), Shenoute implied that God is the protector from enemies and helper of the house of Israel, namely the monastic community during a time of affliction.

\subsubsection{Is It Not Written}

TRACER found no previously unidentified text reuse quotations in Is It Not Written.

\footnotetext{
${ }^{667}$ Ps 67:2-5 (1-4 Budge; 68:1-4).

${ }^{668}$ Ps 67:6-8 (5-7 Budge; 68:5-7).

${ }^{669}$ Ps 67:9-16 (8-15 Budge; 68:8-15).

${ }^{670}$ Ps 67:17-20 (16-19 Budge; 68:16-19).

${ }^{671}$ Ps 67:21-33 (20-32 Budge; 68:20-32).

${ }^{672}$ Ps 67:34-36 (33-35 Budge; 68:33-35).
} 


\subsubsection{Then Am I Not Obliged}

TRACER identified most of the new quotations in the fourth work of Canon 6, Then Am I Not

Obliged. Here, Shenoute quotes several Psalms in reference to his broken vow to God to save a "foolish thing." Instead of being saved, this "foolish thing"- likely a monk—rebelled against Shenoute. The word "save" implies that the monk's course could have been corrected to obey Shenoute and he thus be saved by God. However, there is no specific mention of what the "foolish thing" did. Shenoute declares that it is probably too late to save the man and asks God to forgive him for not doing so. Shenoute then admits that he is guilty of failing to fulfill his vow and, using the psalmist's words, blames himself. During this discourse, Shenoute frequently uses the language of the Psalms; thus, this work contains the most attestations of the new quotations identified by TRACER.

\subsection{Quotation S6}

Shenoute's Canon 6, Then Am I Not Obliged, MONB.XF p. $263^{673}$ and MONB.XM p. $276^{674}$

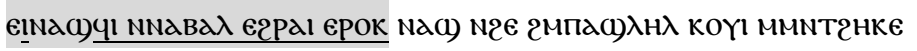

How will I be able to lift my eyes to you in my miserable little prayer?

${ }^{673}$ Zoega 1810: 398-400 (excerpt); Amélineau 1907: xlvi-xlvii, 321 (excerpt); 76-81.

${ }^{674}$ Identical parallel text, except for diacritics. Amélineau 1907: xlvi (excerpt), 79:2-80:10. 
Source: Ps 122:1 (123:1)

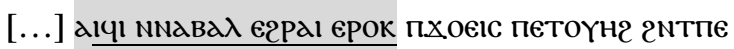

[...]I lifted my eyes to you, O Lord, who dwells in the heaven.

LD: 4, QIPs: none, TR type: near-verbatim quotation [insertions: 2 (Second Tense/focalizing converter e-; potential -c)-), alternation: 1 (Perfect I a- $\rightarrow$ Future Na-)], SM: 8

The two parallel texts in MONB.XF and MONB.XM are identical. There is no QIP, but this text reuse candidate may be a near-verbatim quotation with an insertion of the markers of capability a)- and the focalizing converter e- and the replacement of the Perfect I marker $\mathrm{\alpha}$ - before the first-person singular pronominal subject -1- with the Future Nd- before the verb. The contexts of these two passages are different; Shenoute alludes to Ps 122:1 (123:1) but states that he cannot lift his eyes up to God in a sign of humility because of the sins that he committed.

\subsection{Quotation S7}

Shenoute's Canon 6, Then Am I Not Obliged, MONB.XF p. $264^{675}$ and MONB.XM p. $277^{676}$

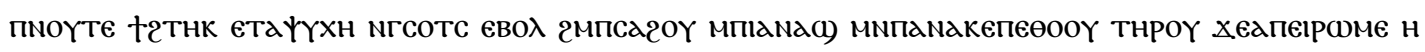

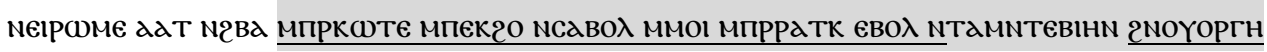

${ }^{675}$ Zoega 1810: 398-400 (excerpt); Amélineau 1907: xlvi-xlvii, 321 (excerpt); 76-81.

${ }^{676}$ Amélineau 1907: xlvi (excerpt), 80-82. 
O God, consider my soul, that you may save it from the curse of this oath and from all my other misdeeds, for this man or these men have made me troubled. Do not turn your face away from me, do $\underline{\text { not turn away from my misery in wrath. }}$

Source: Ps 26:9 (27:9)

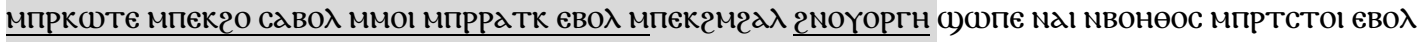
мПРКдат NCOK пNOYTE пасотнР

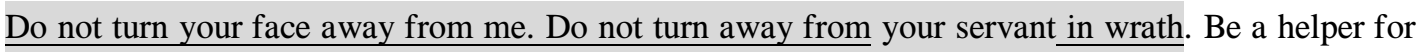
me. Do not reject me. Do not abandon me, O God, my savior.

LD: 13, QIPs: none, TR type: near-verbatim quotation [alternations: 3 (саво $\lambda \rightarrow$ Nсdво $\lambda$; masculine singular possessive article with masculine second-person singular possessor пек- $\rightarrow$ feminine singular possessive article with first-person singular possessor Td-; non-synonymic alternation: 2M2dג or "servant" $\rightarrow$ MNTEBiнм or "misery"], SM: 16

This text reuse candidate is a near-verbatim quotation with a distantly metonymic alternation

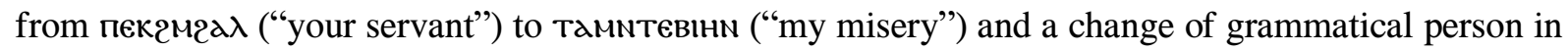
the possessive article from masculine second-person singular to first-person singular. These passages share eight morphs, with a synonymous alternation (саво入 in Ps 26:9 [27:9] $\rightarrow$ мсаво $\lambda$ in Shenoute's Canon 6, Then Am I Not Obliged, MONB.XF p. 264 and MONB.XM p. 277). However, the combination of a preposition and the use of the noun во $\lambda$ as an adverb was counted as a single lexicalized compound adverb. The phrase мпркате мпекго сдвол ммо is also found in other Psalms. 
Shenoute's Canon 6, Am I Not Obliged, MONB.XF p. 264, MONB.XM p. 277

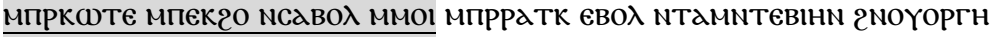

Do not turn your face away from me. Do not turn away from my misery in wrath.

Source candidate: Ps 87:15 (14 Budge; 88:14)

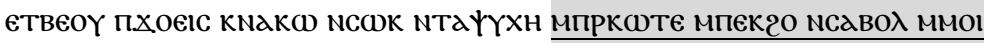

Why, o Lord, will you renounce my soul, do not turn your face away from me.

LD: 0, QIPs: none, TR type: verbatim quotation (however, Ps 26:9 [27:9] has more shared morphs with Shenoute's Canon 6, Am I Not Obliged, MONB.XF p. 264 and MONB.XM p. 277), SM: 9

The above text reuse detected by TRACER shares eight morphs with the source candidate, NсגBO入 ("away") can be parsed into two morphs. However, the combination of a preposition and the use of the noun во $\lambda$ as an adverb was counted as a single lexicalized compound adverb.

Shenoute's Canon 6, Am I Not Obliged, MONB.XF p. 264, MONB.XM p. 277

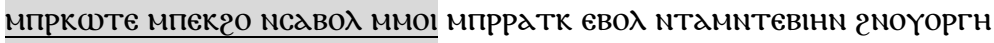

Do not turn your face away from me. Do not turn away from my misery in wrath.

$\underline{\text { Source candidate: Ps 142:7 (143:7) }}$

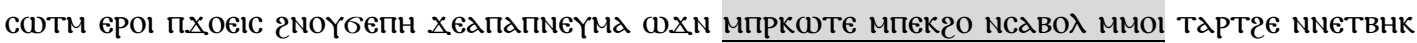
єпєснт єпо)н 
Listen to me, o Lord, in a haste, because my spirit perished, do not turn your face away from me and I will be like those who have gone down into the pit.

LD: 0, QIPs: none, TR type: verbatim quotation (however, Ps 26:9 [27:9] has more shared morphs with Shenoute's Canon 6, Am I Not Obliged, MONB.XF p. 264 and MONB.XM p. 277), SM: 8

However, among the text reuse candidates suggested by TRACER, Ps 26:9 (27:9), which was identified by TRACER, shared the most morphemes with Quotation S7. Therefore, it was concluded that Ps 26:9 (27:9) was the most probable source of this quotation.

\subsection{Quotations S8 and S9}

Shenoute's Canon 6, Then Am I Not Obliged, MONB.XF p. $263^{677}$

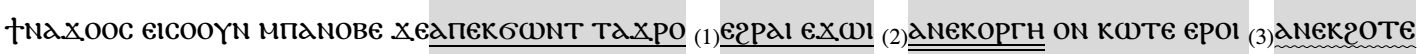

2)трторт Nөє єтсн?

I will say, knowing my sin: "Your anger has been firm (1)으 me; (2) $\underline{\underline{\text { your wrath }}}$ has surrounded me;

(3)your fearful deeds have troubled me, as it is written,

Source: Ps 87:8 (7 Budge; 88:7)

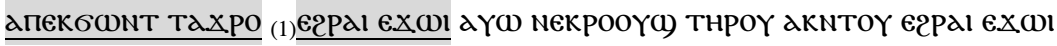

${ }^{677}$ Zoega 1810: 398-400 (excerpt); Amélineau 1907: xlvi-xlvii, 321 (excerpt); 76-81. 
$\underline{\text { Your anger has been firm }}$ (1)으 me, and you have brought all your concerns upon me.

LD: 0, QIPs: Nөє єTcн2, TR type: verbatim quotation, SM: 7

Another source: Ps 87:17 (16 Budge; 88:16)

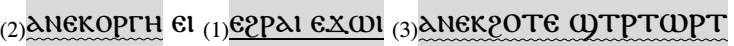

(2) Your wrath has come (1) upon me, and ${ }_{(3)}$ your terrors have troubled me.

LD: 20, QIPs: Nөє єTcH2, TR type: near verbatim quotation with morph order changes [(1) $(2)(3) \rightarrow(2)(1)(3)]$, SM: 11

In this passage, two instances of text reuse were detected; the first was not identified in previous research. The QIP Nөє єтснг ("as it is written") is placed after the two quotations. TRACER suggested two possible source texts in Psalms: Ps 87:8 (7 Budge; 88:7) and Ps 87:17 (16 Budge; 88:16). Shenoute appears to have first quoted Ps 87:8 (7 Budge; 88:7), then 87:17 (16 Budge; 88:16) from the same chapter of Psalms. 


\subsection{Quotation $S 10$}

Shenoute's Canon 6, Then Am I Not Obliged, MONB.XF p. $264^{678}$

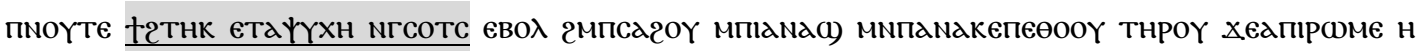

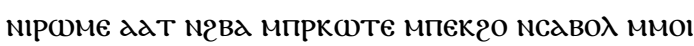

O God, pay attention to my soul and save it from the curse of that oath and from that of all my other misdeeds, because this man or these men have made me embarrassed! Do not turn your face from me!

$\underline{\text { Parallel text with small spelling variants, MONB.XM, p. } 277}$

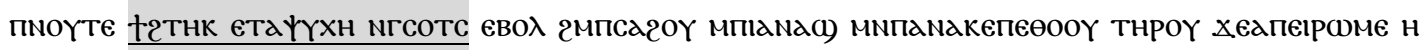

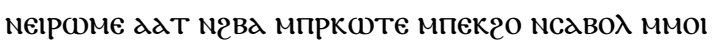

Source: Ps 68:19 (69.18)

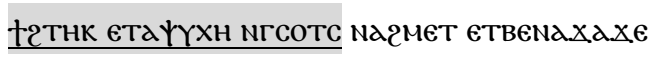

pay attention to my soul and save it; save me because of my enemies

LD: 0, QIPs: none, TR type: verbatim quotation, SM: 10

Ten morphs are shared between the source and target texts. There are no QIPs. Shenoute added

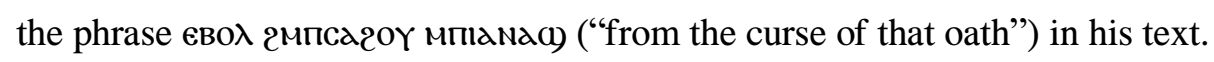

${ }^{678}$ Zoega 1810: 398-400 (excerpt); Amélineau 1907: xlvi-xlvii, 321 (excerpt); 76-81. 


\subsection{Quotation $S 11$}

Shenoute's Canon 6, Then Am I Not Obliged, MONB.XF p. $268^{679}$ and MONB.XM p. 280

$\underline{81}^{680}$

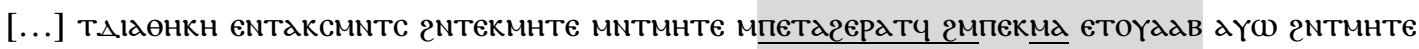
NNal MNNIKOOYE eTO MMNTPE EPON

"[...] the covenant you established in your middle and the middle of the one who stands in your holy place and in the middle of these and those others who are witnesses for us."

Source: Ps 142:7

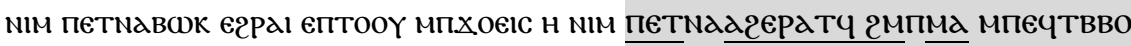

"Who is the one who will go to the mountain of the Lord or who is the one who will stand in the place of his purification."

LD: 11, QIPs: none, TR type: near verbatim quotation [deletion: 1 (Future marker $\mathrm{Nd}-$ ), alternation: 1 (masculine singular definite article $\pi^{-} \rightarrow$ masculine singular possessive article with masculine second-person possessor пек-], SM: 7

${ }^{679}$ Zoega 1810: 401 (excerpts); Amélineau 1907: 82-84.

${ }^{680}$ Amélineau 1907: 82-85. 
In Quotation S11, the text reuse is possibly a quotation with a synonymic alternation from мпєчтвво ("of his purity") to єтоүадв ("which is holy") and an article alternation from the definite article ח- ("the") to the masculine second-person singular possessive article пєк- (“your"). No QIP were attested.

\subsection{Quotation $S 12$}

Shenoute's Canon 6, Then Am I Not Obliged, MONB.XF p. $274^{681}$ and MONB.XM p. $286^{682}$

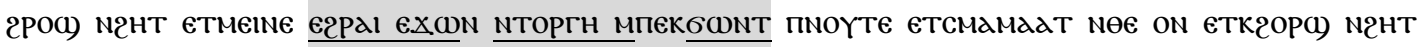
NoYoeic) NIM

Be long-suffering not to bring upon us the wrath of your anger; $\mathrm{O}$ blessed God, as you have been longsuffering at all times $[\ldots]$

Source: Ps 77:49 (78:49)

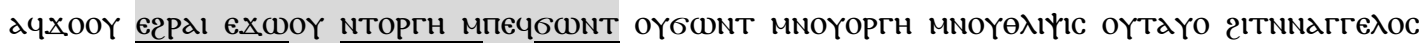
мпомнрос

He sent upon them the wrath of his anger, an anger and a wrath and an affliction, a dispatch through the wicked angels.

${ }^{681}$ Zoega 1810: 401 (excerpts); Amélineau 1907: 85-88.

${ }^{682}$ Amélineau 1907: 87-88. 
LD: 7, QIPs: none, TR type: near-verbatim quotation [alternations: 2 (third-person plural personal suffix $\rightarrow$ first-person plural personal suffix; masculine singular possessive article with masculine third-person singular possessor $\rightarrow$ masculine singular possessive article with secondperson masculine singular possessor)], SM: 7

There were no QIPs before or after the quotation. The text reuse was a near-verbatim quotation with synonymic alternation of the verb from xoor ("send") in Ps 77:49 (78:49) to eine ("bring") in Shenoute's Canon 6, Then Am I Not Obliged, MONB.XF, p. 274 and MONB.XM, p. 286 and alterations in person from the masculine third-person singular пєч- "his" to the masculine second-person singular пєк- "your" in a possessive article and the third-person plural -ơ "them" to the first-person plural - $\mathrm{N}$ "us" in a pronominal suffix. The two texts share seven morphemes. eive and xooY could potentially have been included as a text reuse case because this is a marginal text reuse case. However, the meanings of these verbs are similar due to their synonymic relation: eine ("bring") and xooY ("send"). Thus, it is likely that eive ("bring") is part of Quotation S12. However, due to this uncertainty, the two verbs were excluded from the analysis. 


\subsection{Quotation $S 13$}

Shenoute's Canon 6, Then Am I Not Obliged, MONB.XM p. 301-02

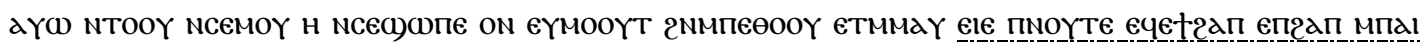

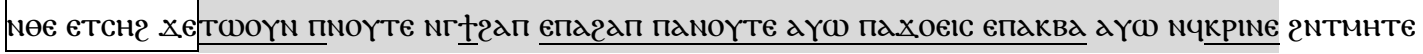

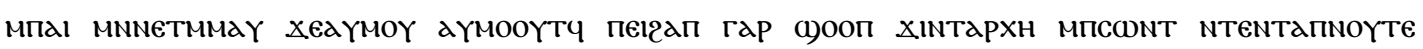
таміепроме 2l.xNחка2

And they die or are dead in these evils, then God will judge the judgment of this one, as it is written, “Arise, O God, judge my judgment, O my God and O my Lord, for my vengeance, and let him judge between this and those," because they died, they killed him, for this judgment exists from the beginning of the creation when God created the man on the earth.

Source: Ps 34:23-24 (35:23-24)

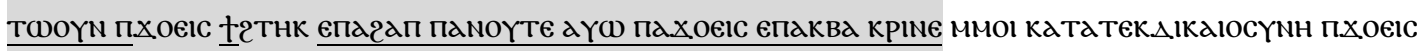
паNоҮте мпртреҮрас)є ммо

Arise, O Lord, pay attention to my judgment, O my God and my Lord, for my vengeance, judge me according to your righteousness, Lord, my God, do not let them rejoice about me.

LD: 15, QIPs: мөє єтснг хє-, TR type: modified quotation [alternations: 2 (synonymous: xoє1c or "Lord" $\rightarrow$ NOYTe or "God"; non-synonymous: 2THK or “your heart" $\rightarrow$ 2an or "judgment"),

${ }^{683}$ Amélineau 1907: 99-100. 
insertions: 5 (Conjunctive $\mathrm{N}$ - and masculine second-person singular personal prefix $\Gamma$ - before "give judgment"; a $\ \omega$ or "and"; Conjunctive $\mathrm{N}^{-}$and masculine third-person singular personal prefix ч- before kpine or "judge")], SM: 15

This text reuse is a modified quotation that contains a QIP: Ne€ єтснг $\chi €-$ (“as it is written ...”). Before the QIP, the quotation is written as a precursor: є1є пмоүте ече†гап епгап мпал ("then God judges the judgment of this"). It is well-attested that Shenoute frequently employed this construction: "[near-verbatim quotation], as it is written, [verbatim quotation]."

The quotation was altered with regard to the synonymic relation between two lexemes: from xoeıc ("Lord") to noYTe ("God"). Shenoute added the pronominal subjects and Conjunctive auxiliaries

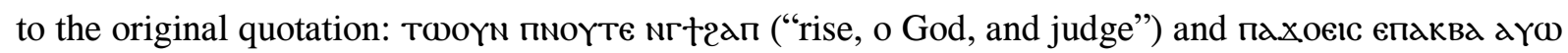
Nчкpine ("and o my Lord, for my vengeance, and let him judge"). In doing so, it would appear that Shenoute clarified the subjects, but the exact function of these insertions is unknown. Shenoute added the morphs underlined in the above passages. He also replaced 2тHк with 2aח; consequently, the meaning of the first sentence differs from the quotation in Psalms: from †थтнк епд2ап ("pay attention to my judgment") to мг†२ап епагап (“judge my judgment”). Amélineau claimed that this was a quotation from Ps 83:22; however, Ps 83:22 does not exist in the Septuagint. Probably it is a mistake for Ps 73:22 (74:22). 
Amélineau himself confirms a huge difference between Shenoute's Canon 6 (Then Am I Not

Obliged, MONB.XM, p. 301-02) and Ps 83:22 (=73:22 [74:22]). ${ }^{64}$ Ps 34 (35) shares more morphs with Shenoute's quotation and is more similar to it than Ps 73:22 (74:22). Ps 73:22 (74:22) is presented below.

\section{$\underline{\text { Source candidate: Ps 73:22 (74:22) }}$}

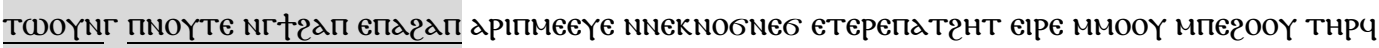

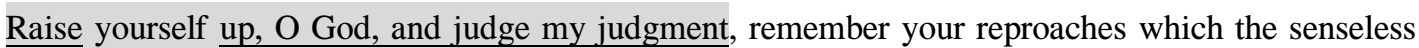
does all the day.

If Shenoute's passage quotes Ps 73:22 (74:22), the LD would be 1 and the TR type would be a verbatim quotation with a deletion of the reflective object masculine second-person singular personal suffix (-г). The LD is low, and Shenoute's passages shares fewer morphs [10 morphs] with Ps 73:22 (74:22) than with Ps 34:23-24 (35:23-24) [16 morphs]. Therefore, Ps 34:23-24 (35:23-24) is more likely to be the source of the quotation. However, there is still a possibility that its source is Ps 73:22 (74:22) or that Shenoute quoted combined similar quotations from the Psalms.

684 “Psalm., LXXXIII, 22; mais ce verset ne dit pas ce que Schenoudi lui fait dire.” (Amélineau 1907: 100) Probably lui ("it") in the comment by Amélineau means ce verset ("the verse"), and Amélineau meant that Shenoute's verse is very different from Ps 83:22. Ps 83:22 is a mistake for Ps 73:22 (74:22). 


\subsection{Chapter summary}

Chapter 5 explored five quotations from Besa's Letters and Sermons and 13 quotations from Shenoute's Canon 6 that were newly identified by TRACER identified as potential text reuse candidates. Each quotation's LD, QIPs, and shared morphemes were described and calculated to analyze quotations by Shenoute and Besa from Psalms. In addition, it was noted whether the quotations had been identified in previous studies. Basic statistics for these values are shown in Table 24.

\begin{tabular}{|l|l|l|l|l|l|l|l|l|l|l|l|l|l|l|l|l|l|l|}
\hline & B1 & B2 & B3 & B4 & B5 & S1 & S2 & S3 & S4 & S5 & S6 & S7 & S8 & S9 & S10 & S11 & S12 & S13 \\
\hline LD & 15 & 2 & 0 & 3 & 13 & 1 & 8 & 3 & 23 & 0 & 4 & 13 & 0 & 20 & 0 & 11 & 7 & 15 \\
\hline QIP & 0 & 0 & 0 & 0 & 0 & 0 & 0 & 0 & 0 & 0 & 0 & 0 & 1 & 1 & 0 & 0 & 0 & 1 \\
\hline SM & 14 & 11 & 18 & 11 & 11 & 6 & 21 & 5 & 6 & 7 & 8 & 16 & 7 & 11 & 10 & 7 & 7 & 15 \\
\hline $\begin{array}{l}\text { Previous } \\
\text { studies }\end{array}$ & K & K & K & K & K & AB & AB & AB & A & U & ZA & ZA & ZA & ZA & ZA & ZA & ZA & A \\
\hline
\end{tabular}

Table 24: Summary of Levenshtein Distance, quotative index phrases, shared morphemes, and previous studies for quotations newly identified by TRACER (LD = Levenshtein Distance, $\mathrm{QIP}=$ quotative index phrase, $\mathrm{SM}=$ shared morphs, $\mathrm{K}=$ Kuhn, $\mathrm{A}=$ Amélineau, $\mathrm{B}=$ Behlmer, $\mathrm{Z}=$ Zoega, $\mathrm{W}=$ Wiesmann, $\mathrm{Y}=$ Young, $\mathrm{L}=$ Layton,

$$
\mathrm{U}=\text { Unpublished). }
$$

The LD differed from quotation to quotation, and it was not possible to generalize any trends from the data in Table 24. However, a significant tendency was noted with regard to QIPs in all the quotations that were newly identified by TRACER but not in previous studies: none of the quotations from Besa's Letters and Sermons contained QIPs and three out of 11 quotations from Shenoute's Canon 6 contained QIPs. This indicates that, as expected, quotations with QIPs are more easily identifiable manually. Since Shenoute and Besa rarely specified biblical books for their sources, it was reasonable for these scholars to focus on sentences that contained QIPs to detect intertexts. 
Compared to the grammatical analysis of biblical quotations conducted by Shisha-Halevy, this study examines whether the newly discovered quotations included the grammatical characteristics proposed by Shisha-Halevy. ${ }^{685}$ In particular, some characteristics of biblical quotations - the special Conjunctive Future first-person singular Td- or a special apodotic form TגPeq- — was not attested in the newly found quotations by TRACER (B1-B5 and S1-S13). ${ }^{686}$

${ }^{685}$ Shisha-Halevy 1986: 53. See Subsection 2.6.1.

${ }^{686}$ For details about тapє4-, see Shisha-Halevy 2016b: 122; "special apodotic form" is his wording. 


\section{Conclusion and future perspectives}

The present research uses a pioneering approach by employing the digital text reuse software TRACER to identify instances of text reuse in digital versions of Coptic texts. However, the true benefits of this approach will be seen when the corpus of digitized Coptic texts is sufficiently large to constitute big data. Thus, this study aims to stimulate significant future research that makes use of Coptic big data.

Six research questions were presented in the first chapter of this dissertation. They were answered by reflecting on findings from the literature review in Chapter 2 and the results of TRACER's digital text reuse analysis in Chapter 5, specifically on the corpus of the Psalms, Shenoute's Canon 6, and Besa's Letters and Sermons. In addition, answers to the research questions were informed by the sermons described in Chapter 4, which were obtained through the digital humanities methods and tools described in Chapter 3.

\subsection{Research question 1}

The first research question was, "Do the textual findings indicate quotations from memory rather than from books or excerpts?" Based on the research findings, there is still not enough decisive evidence to conclude whether Shenoute and Besa quoted the Bible from memory or by examining books or excerpts. However, there is a possibility that they did both.

In Chapter 5, quotations that had not been previously found in studies were presented. According to the text reuses identified by TRACER, the indicator used to measure similarities between 
textual passages, the Levenshtein Distance (LD) was often large (6.6 in Besa's works and 8 Shenoute's works, on average; see Table $24^{687}$ ), which means that the quotations were usually not verbatim. Based on these divergences from the original text, it is possible that Shenoute and Besa quoted passages from memory. This hypothesis is based on the fact that members of the White Monastery federation were expected to learn the Bible by heart as part of their daily practice. ${ }^{688}$ In addition, the rules of the White Monastery federation required monks and nuns to read them aloud, even when they were alone. ${ }^{689}$ This study demonstrated that Shenoute and Besa intentionally changed the original text to recontextualize it according to their rhetoric aims in the discourses as evidenced by findings from the literature review. ${ }^{690}$ Nevertheless, this intentional alteration of the original biblical text does not answer the first research question, since Shenoute and Besa could have done so by quoting the Bible either from memory or sight. The longest quotation from the Psalms discussed in Chapter 5 shared 20 and 18 morphs with Shenoute's Canon 6 and Besa's Letters and Sermons, respectively (see Quotations S2 and B3 in Table

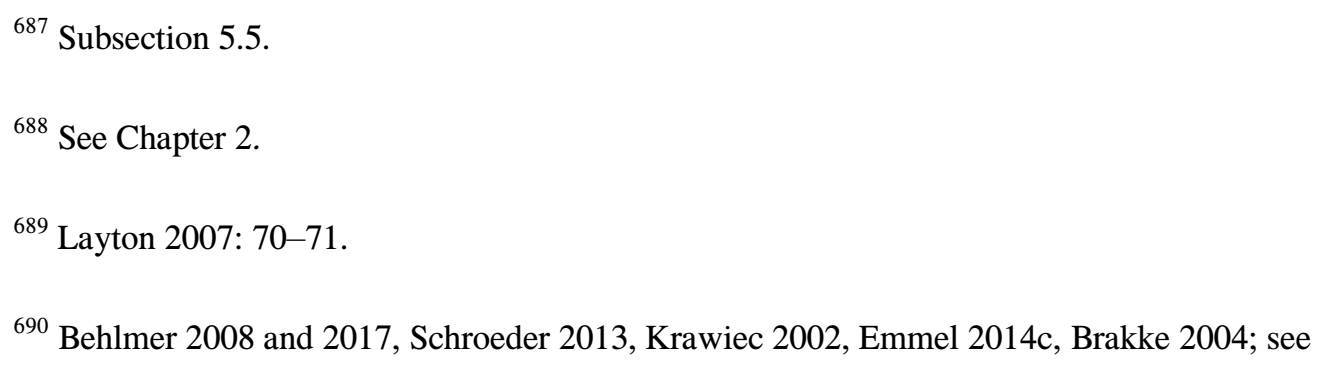


$24^{691}$ ). Conversely, the shortest quotation from the Psalms shared six morphs with Shenoute's Canon 6 and nine morphs with Besa's Letters and Sermons (see Quotations S1 and B4 in Table $24^{692}$ ).

Hugo Lundhaug explored the memory of early cenobitic monastic figures in Egypt by focusing on Shenoute and Horsiesios, mainly from the perspective of cognitive sciences. Specifically, Lundhaug focused on how the biblical language interwoven in Shenoute's discourse invoked the collective memory of the monastic community ${ }^{693}$ As argued by Lundhaug, Shenoute and Besa were not concerned with the quotations' accuracy but rather invoked monks and nuns' collective memory of the Bible by blending biblical concepts and language with their current monastic situation. ${ }^{694}$

\subsection{Research question 2}

The second research question ("How accurate is the quotation? How can discrepancies be explained?") was informed by the quotations discussed in Chapter 5. According to the findings, most text reuse cases

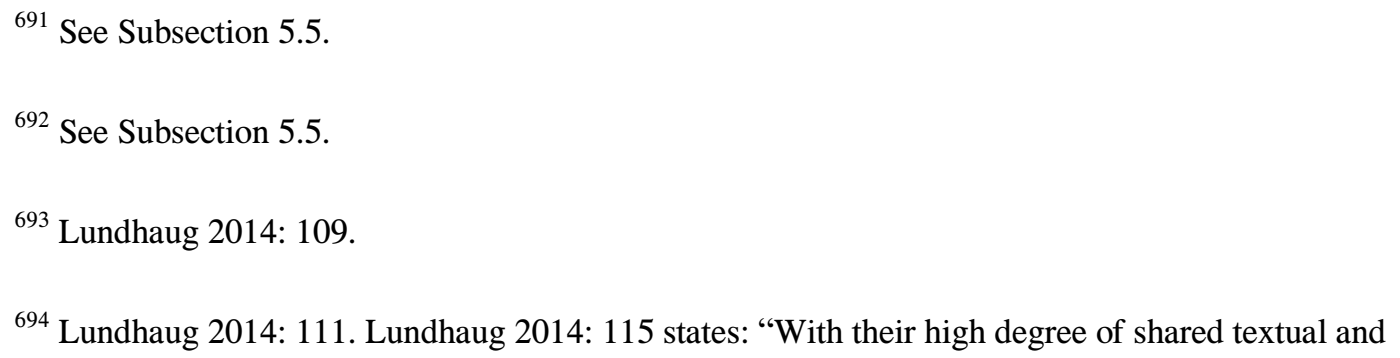


were near-verbatim or heavily altered quotations, as the average LD was 6.6 for Besa's works and 8 for Shenoute's works. In addition, one out of five and four out of 13 text reuses in Besa's Letters and Sermons and Shenoute's Canon 6, respectively, were verbatim quotations. Thus, of these quotations discussed in Chapter 5, there are many changes made by Shenoute and Besa. Most changes that they made to the biblical source text were typologized as follows: ${ }^{695}$

- Morph alternations: ${ }^{696}$ Quotations B1 (one alternation), B2 (one alternation), B4 (two alternations), B5 (four alternations), S1 (one alternation), S2 (two alternations), S3 (two alternations), S4 (two alternations), S6 (one alternation), S7 (three alternations), S11 (one alternation), S12 (two alternations), and S13 (two alternations)

- Morph deletions: Quotation B1 (three deletions), S2 (one deletion), B2 (one deletion), S4 (two deletions), and S11 (one deletion)

- Morph insertions: Quotations S4 (three insertions), S6 (two insertions), and S13 (five insertions)

- Morph order changes: Quotation S9 (one change)

- Verbatim quotations: Quotations B3, S5, S8, and S10

In this study, a comprehensive analysis of textual witnesses of the Psalms to determine the version of the Sahidic translation of the Psalms used by Shenoute and Besa was not performed. However,

${ }^{695}$ See Table 24 in Section 5.5.

${ }^{696}$ A deletion and an addition in the same place are counted as one alternation. 
Bąk conducted a textual study of Psalms passages quoted by Shenoute in As I Sat on a Mountain. ${ }^{697}$ Specifically, he compared Shenoute's quotations from the Psalms with the text of major existing Psalter manuscripts. ${ }^{698}$ Bąk's conclusions are that Shenoute's quotations do not very much differ from the major existing Psalter manuscripts. When there are differences between Shenoute's quotation and the Psalter manuscripts, they are spelling variants, or it seems Shenoute changed the wording intentionally. The latter point that the author altered the wording intentionally is true in Shenoute and Besa's quotations analyzed in this study (B1, B2, B4, B5, S1, S2, S3, S4, S6, S7, S11, S12, and S13 ${ }^{699}$ ). Mostly their modifications are changes in grammatical person, gender, number, or case (B4, S1, S2, S3, S4, S7, S12, and $\mathrm{S} 13^{700}$ ) or in tense $\left(\mathrm{B} 1, \mathrm{~B} 2, \mathrm{~B} 4, \mathrm{~B} 5, \mathrm{~S} 3, \mathrm{~S} 4, \mathrm{~S} 6\right.$, and $\left.\mathrm{S} 13^{701}\right)$. In addition, occasional synonymic word changes were observed (S4, S7, S13 ${ }^{702}$ ). These grammatical and synonymic changes were probably not

${ }^{697}$ Bąk 2015. Bąk calls this work Ad Philosophum Gentilem, using the title given by Leipoldt (Leipoldt and Crum 1908 and 1913).

${ }^{698}$ Bąk 2015: 77-78.

${ }^{699}$ See Subsection 5.4.2.1 for B1, 5.2.2.2 for B2, 5.4.2.6 for B4, 5.4.2.7 for B5, 5.4.4.1.2 for S2, 5.4.4.1.3 for S3, 5.4.4.1.4 for S4, 5.4.4.4.1 for S6, 5.4.4.4.2 for S7, 5.4.4.4.5 for S11, 5.4.4.4.6 for S12, and 5.4.4.4.7 for $\mathrm{S} 13$.

${ }^{700}$ See Subsection 5.4.2.6 for B4, 5.4.4.1.1 for S1, 5.4.4.1.2 for S2, 5.4.4.1.3 for S3, 5.4.4.1.4 for S4, 5.4.4.4.2 for S7, 5.4.4.4.6 for S12, and 5.4.4.4.7 for S13.

${ }^{701}$ See Subsection 5.4.2.1 for B1, 5.2.2.2 for B2, 5.4.2.6 for B4, 5.4.2.7 for B5, 5.4.4.1.3 for S3, 5.4.4.1.4 for S4, 5.4.4.4.1 for S6, and 5.4.4.4.7 for S13.

${ }^{702}$ See Subsection 5.4.4.1.4 for S4, 5.4.4.4.2 for S7, and 5.4.4. 
caused by differences in the Psalm texts between CoptOT's base text and the Psalm text(s) used by Shenoute and Besa. ${ }^{703}$ Rather, their motivation for the changes seems to be to seamlessly integrate the Psalm phrases into their monastic discourses. Therefore, it could be said that Shenoute and Besa's modifications of the original Psalms passages were mostly due to grammatical or synonymic adjustment that arose in the process of recontextualizing the phrases of the Psalms to fit their monastic issues.

\subsection{Research question 3}

The third research question was, "What contextual signals were employed to mark quotations?" Shenoute and Besa used quotative index phrases (QIPs) to mark quotations, ${ }^{704}$ as seen in Subsection 2.6.4 for Besa, and Subsection 2.6.3 as well as S8, S9, and S13 for Shenoute. The most controversial QIP of the quotations discussed in Chapter 5 was nөє єтсн2 (“as is written”). How this QIP was used across the entire corpus of Shenoute's Canon 6 and Besa's Letters and Sermons was further studied in a collaboration between the present author and Heike Behlmer. The result will be published as an article. $^{705}$ Miyagawa and Behlmer state that nөє єтснг occurred 36 times in Shenoute's Canon 6 and 49

\footnotetext{
${ }^{703}$ For the base text of CoptOT and its editing process based on Psalter manuscripts, see Section 4.1.

${ }^{704}$ For QIPs, see Subsections 2.6.2-2.6.4 and Miyagawa and Behlmer (forthcoming a and b).

${ }^{705}$ Miyagawa and Behlmer (forthcoming b)
} 
times in Besa's Letters and Sermons and examined the position of the QIP. ${ }^{706}$ It was variously placed before the quotation (pre-posed), within the quotation (inserted), and after the quotation (post-posed). Miyagawa and Behlmer were able to show that most of QIPs in Shenoute's Canon 6 were post-posed (64\%). Only $21 \%$ were pre-posed. Conversely, in Besa's Letters and Sermons, $80 \%$ of quotations were pre-posed and $14 \%$ were post-posed. Thus, it can be concluded that this difference between the two authors was principally a matter of style, although it does suggest that Shenoute was more likely to incorporate quotations, particularly from the Bible, in his core arguments. However, the study was only limited to Nөє єтснг ("as is written"). In the corpus of Shenoute and Besa, the frequency and trends of QIPs other than Nөє єтсн2 ("as is written") need to be examined.

\subsection{Research question 4}

The fourth research question was, "Is there a connection between the introduction of a biblical argument and the faithfulness of a quotation? In other words, is an adoption marked as a quotation more literal than an unmarked adoption?"

Chapter 5 showed that the percentage of quotations that contained a QIP was 17\% (three out of 18 Psalm quotations in Shenoute's Canon 6 and Besa's Letters and Sermons). Two out of these three

${ }^{706}$ All analysis on the use of the QIP nөє єтснг in Shenoute's Canon 6 and Besa's Letters and Sermons will be published as Miyagawa and Behlmer (forthcoming b). 
examples (Quotations S8 and $\mathrm{S9}^{707}$ ) were quotations with an LD of 0 , which indicates verbatim quotations. Thus, quotations with a QIP were more faithful to the original biblical passage than those without a QIP. However, the LD of the third quotation with a QIP (Quotation S13 ${ }^{708}$ ) was 15 , which means the quoted text was very different from the original. While Quotations S8 and S9 both contained a post-posed QIP ( мөє єтсн2), Quotation S13 contained a pre-posed QIP (nеє єтснг хє-). However, it would be misguided to argue the faithfulness of a quotation based on whether it contains a pre-posed or post-posed QIP. It is also important to consider the possibility that Quotation S13 is a faithful quotation but that the versions of the Psalms that Shenoute quoted are different from CoptOT's base text. In addition, all QIPs in biblical quotations from Shenoute and Besa's writings must be examined to determine the relationship between types of QIP and the faithfulness of the quotations. This constitutes one of the most important challenges to address in future research.

\subsection{Research question 5}

The fifth and last research question was, "What are the opportunities and limitations of digital tools?" Although TRACER identified new text reuses in this research, the time needed for preparation and pre-processing was four years. The processing stage itself was rapid, but it was less rapid overall than experienced biblical scholars such as Wiesmann and Kuhn. Nevertheless, it is significant that

\footnotetext{
${ }^{707}$ See Subsection 5.4.4.4.3.

${ }^{708}$ See Subsection 5.4.4.4.7.
} 
TRACER identified text reuses that Kuhn, an experienced biblical and Coptic scholar, did not. Thus, based on the study's results, it can be said that digital tools can be useful for scholars of fields other than biblical studies and students with less experience in reading the Bible. Through the comprehensive workflow of corpus building and text reuse detection analysis, ${ }^{709}$ the digital text reuse detection process revealed previously unknown instances of text reuses from the Psalms in Shenoute's Canon 6 and Besa's Letters and Sermons. At the same time, the results revealed problems with this workflow, such as a number of invalid text reuse candidates. They mostly consisted of idiomatic text reuses, which were not within the scope of this study.

As for quotations, TRACER found 23 and 46 from the Psalms in Shenoute's Canon 6 and Besa's Letters and Sermons, respectively. ${ }^{710}$ Among these, 14 quotations in Shenoute's Canon 6 and five quotations in Besa's Letters and Sermons were newly identified. It is noteworthy that TRACER found quotations that even Kuhn, an experienced biblical scholar, could not find. But, on the other hand, there are also quotations which were found by Kuhn but not by TRACER.

There is a lot of room for improvement in the workflow for the pre-processing, processing, and post-processing shown in Section 3.2. Recently, Coptic SCRIPTORIUM improved its tokenizer and lemmatizer tools by adopting the latest deep learning technology. Thus, it is expected that future research conducted with the same workflow and corpus used in this study will produce better results. In addition, the present results can be improved through the advancement of TRACER itself, such as through the

\footnotetext{
${ }^{709}$ For the computational workflow employed in this study, see Section 3.2.

${ }^{710}$ See Subsection 5.4.4.
} 
NLP tools provided by Coptic SCRIPTORIUM. Since the last TRACER processing performed in 2018, many improvements in Coptic SCRIPTORIUM's NLP tools have been made through new deep learning technology ${ }^{711}$ Notably, the quotations that were newly identified by TRACER had only been studied by Amélineau and Zoega. TRACER could not find any previously unknown quotations in sections that had been studied by Wiesmann, who produced a Latin translation of part of Shenoute's Canon 6 based on Leipoldt's editions. Finding the quotations that Wiesmann could not find might be a good next goal for TRACER's text reuse detection.

These are the answers to the research questions, as far as the present author can tell from the results of this study. It can be concluded that Shenoute and Besa are typical examples of "mosaïque de citations," as argued by Kristeva. ${ }^{712}$ Her argument that "tout texte est absorption et transformation d'un autre texte" seems to be true in most cases of Shenoute and Besa's monastic discourses, because they incorporated the biblical language into their works in various ways: verbatim quotation, near-verbatim quotation, paraphrase, and just allusion, without or with signals to notify the monks and nuns that they

${ }^{711}$ See Zeldes's latest presentation at the KUDH International Conference "Digital Transformation in the Humanities." The presentation is titled "UD Treebanking for Coptic DH: Low Resource NLP Technologies for NER, Lexicography and Linked Open Data." The video recording of the presentation is available at https://www.kyoto-u-digitization.org/oct-2-digital-corpus-universal-dependencies-east-asian-and-coptic, last accessed on December 14, 2021.

${ }^{712}$ Kristeva 1969: 84-85; see Subsection 2.1.1. 
are using the biblical language. It is well-documented that they skillfully and seamlessly interweaved biblical texts into their discourses while altering, deleting, or adding morphs when necessary to recontextualize the passages for their monastic situation. Usually, they deeply internalized the biblical texts and concepts into their own writings without any indication of having done so, although they sometimes clearly indicated that their wording was derived from the Bible. In particular, in the case of the Psalms, the function of indicating a quotation may be unclear, as at least part of the intended audience would have been able to know the Psalms, or some of them, by heart. As a result, it may have been less necessary for Shenoute and Besa to indicate that they were quoting from this biblical book. The Pachomian rules compelled monks and nuns to learn at least the Psalms by heart, and the rules of the White Monastery Federation were probably based on the Pachomian rules. ${ }^{713}$ It is possible that, by using QIPs, Shenoute and Besa sought to strengthen monks and nuns" "collective memory" of biblical events and underline concepts that were relevant to the monastic community.

As Lundhaug indicated about Shenoute and Horsiesios, ${ }^{714}$ by evoking this biblical collective memory, Shenoute and Besa sought to strengthen the monks' and nuns' identity as a single monastic community. At the same time, the abbots seamlessly connected the monastic community's current situation with those of the nation of Israel (as described in the OT), the disciples of Jesus, and the later church community of the apostolic period in the first century. In addition, since monks and nuns were forced to memorize the Bible, reading Bible verses aloud throughout the territory of the White

\footnotetext{
${ }^{713}$ See Subsection 2.6.2.

${ }^{714}$ Lundhaug 2014.
} 
Monastery Federation ${ }^{715}$ enabled them to internalize the memories of characters in the Bible as their own. The collective memories of the White Monastery Federation consisted of memories from what is written in the OT and NT along with the memory of the events in the federation. Moreover, in this seamlessly combined collective memory, the monks and nuns' superiors - namely abbots such as Shenoute and Besa - played the role of prophets and leaders from the OT and the NT, such as the psalmist, Isaiah, Jeremiah, and the greatest early church leaders such as the Apostle Paul. The monastic body internalized the metaphor of the abbot as the prophet or apostle and the monks and nuns as members of the house of Israel or early believers in Christianity.

Lundhaug's recent work uses the frameworks of cognitive linguistics, such as the theories of mental space and conceptual blending, to analyze the words and actions of figures who lived in ancient monasteries. ${ }^{716}$ In the framework of his cognitive research method, Shenoute's and Besa's seamless interweaving of biblical verses into their own letters and sermons could be described as a tool to blend two distinct mental spaces: the biblical mental space and the monastic mental space. ${ }^{717}$

\footnotetext{
${ }^{715}$ See Layton 2007: 70-71. 2009.

${ }^{716}$ Lundhaug 2010a and 2010b, inter alia. Also see Lundhaug 2008 and 2014. For more on the mental
} space theory, see Fauconnier 1994; for more on the conceptual blending theory, see Fauconnier and Turner 2008.

${ }^{717}$ The biblical mental space could be what Timbie 2011: 510 called "mental dictionary," from which Shenoute quoted Scripture. 
The density of biblical intertexts interwoven in their discourses makes us think that most of the passages in writings of Shenoute and Besa have some form of quotation from or allusion to the Bible. However, in order to confirm this, it would be necessary to find all the intertexts in all the works of Shenoute and Besa, and then conduct an objective and empirical analysis using a corpus. To do so, digital humanists and computer scientists familiar with digital methods, such as improved versions of TRACER, and preprocessing tools, and experienced biblical and Coptic scholars must join forces to find the intertexts in the works of Shenoute and Basa, both digitally and manually. 


\section{Appendix}

The following table (Table 25) shows the correspondences between Morpheus-based simple part-ofspeech (POS) tagset and Coptic SCRIPTORIUM's fine POS tagset. Underlines denote a coarse POS tag set of Zeldes and Schroeder 2016b: 2-3.

\begin{tabular}{|c|c|}
\hline Tag & Content \\
\hline $\mathrm{a}$ & 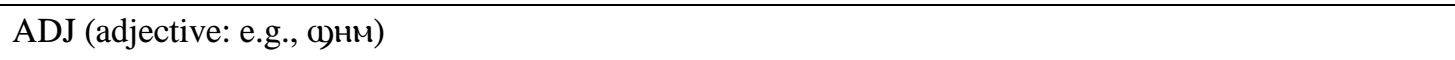 \\
\hline $\mathrm{d}$ & ADV (adverb: e.g., єво入, пюс) \\
\hline $\mathrm{c}$ & 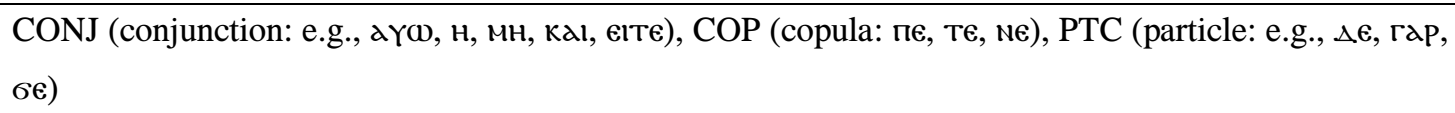 \\
\hline $\mathrm{e}$ & UNKNOWN (unknown words: lacuna, damaged words, etc.) \\
\hline $\mathrm{g}$ & 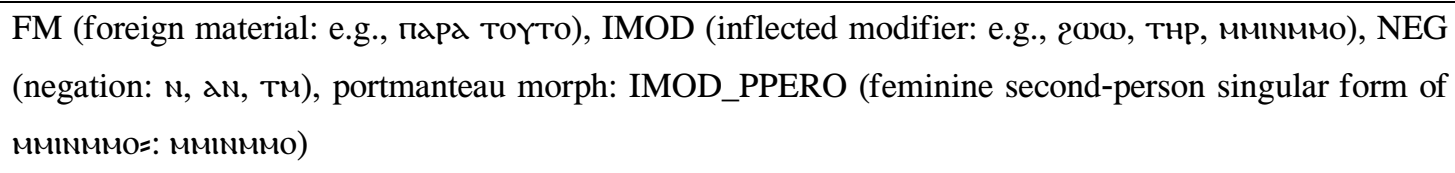 \\
\hline 1 & ART (article: e.g., п-, oY-, кє-) \\
\hline $\mathrm{m}$ & NUM (numeral: e.g., oya, cnaY, a)ac) \\
\hline $\mathrm{n}$ & 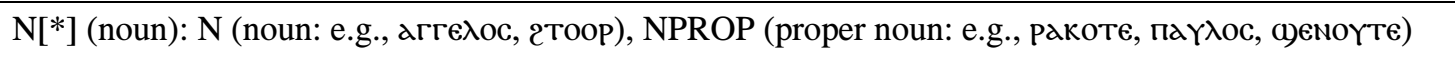 \\
\hline 0 & 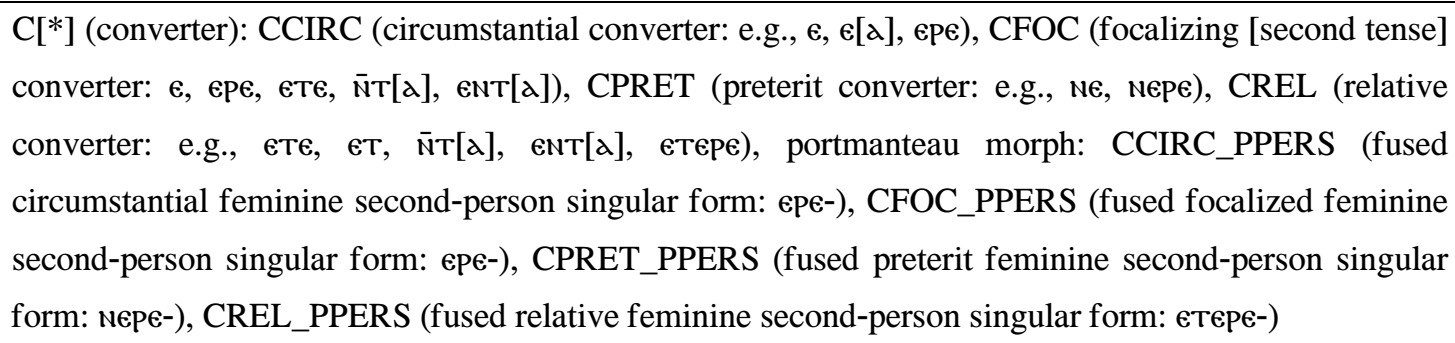 \\
\hline $\mathrm{p}$ & 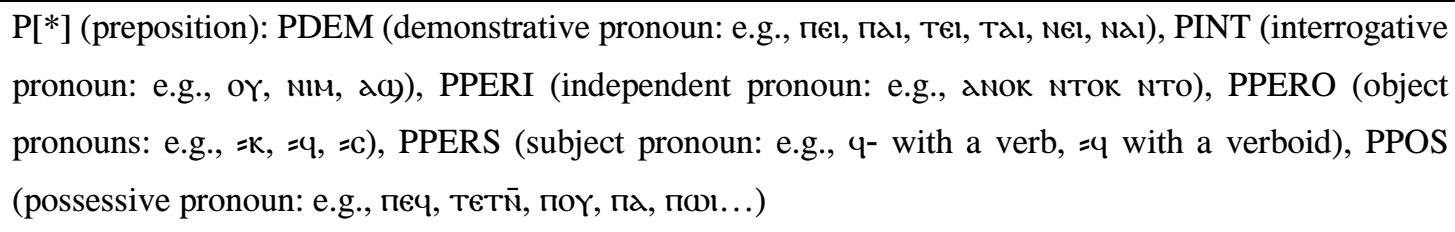 \\
\hline $\mathrm{r}$ & 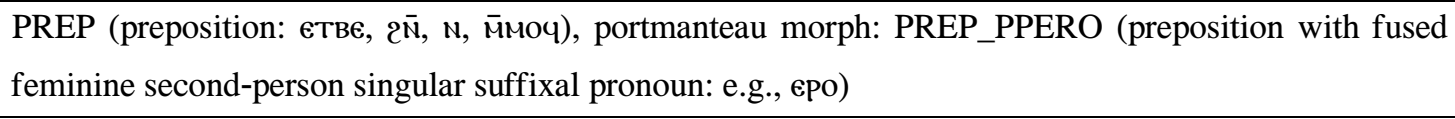 \\
\hline $\mathrm{V}$ & 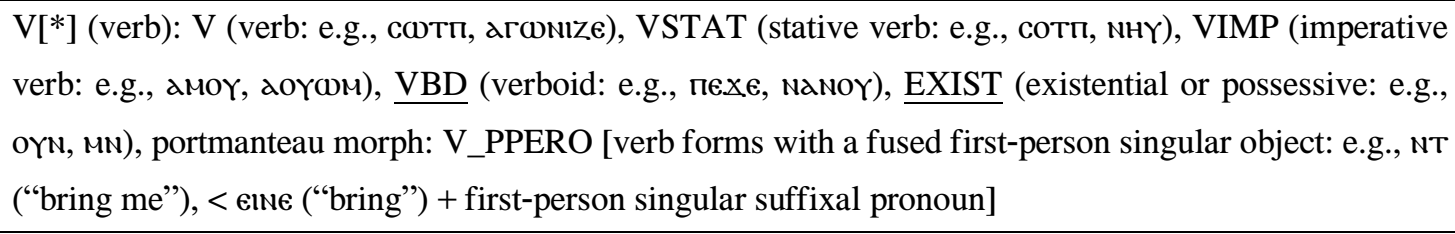 \\
\hline
\end{tabular}




\begin{tabular}{|c|c|}
\hline $\mathrm{x}$ & 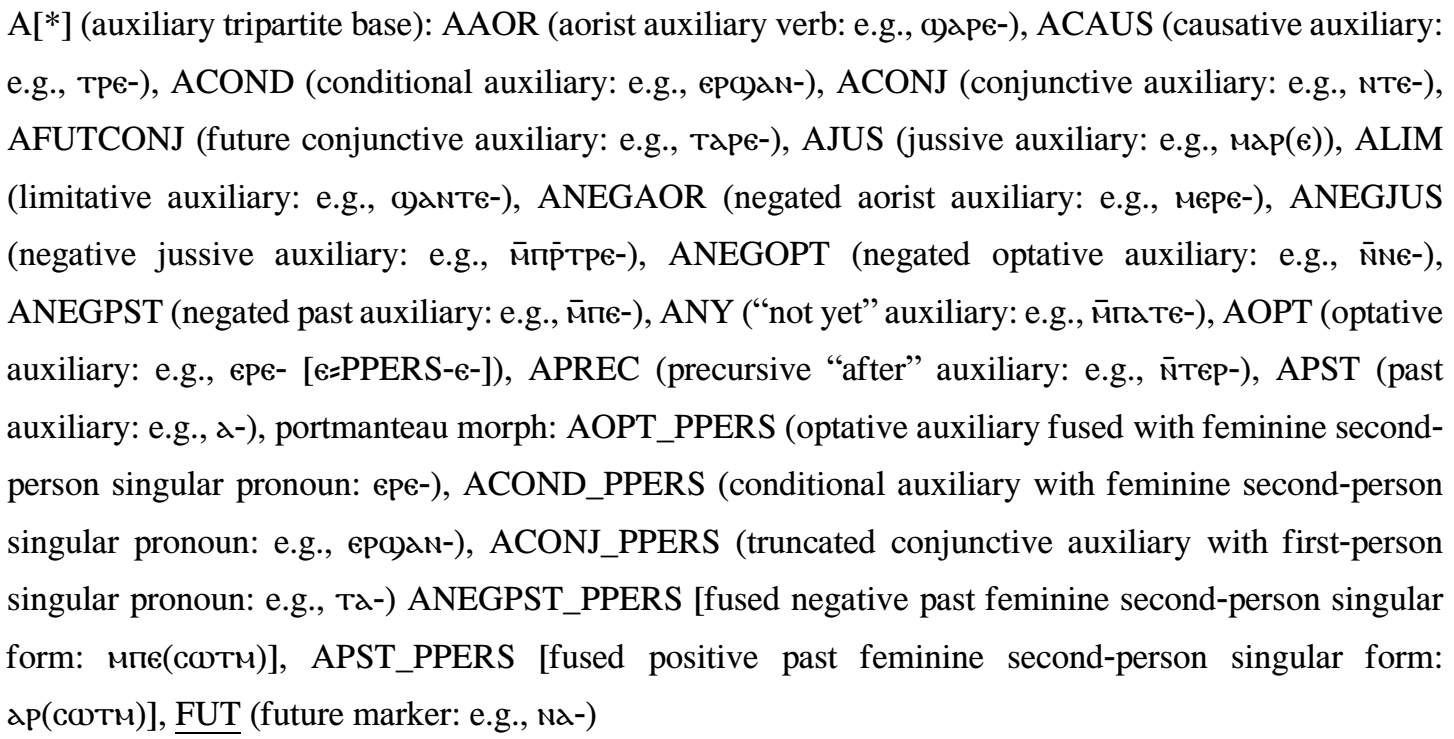 \\
\hline $\mathrm{u}$ & PUNCT (., ’’) \\
\hline
\end{tabular}

Table 25 Correspondences between Morpheus-based POS tagset and Coptic SCRIPTORIUM's fine POS tagset 


\section{List of tables}

Table 1: Einleitungen used by Besa to indicate quotations.

Table 2: Percentage of pages from Shenoute's Canon 6 held at modern institutions.

Table 3: Number of pages in each codex as a percentage of total pages in Canon 6.

Table 4: Number of pages in each work as a percentage of total pages in Canon 6.

Table 5: Pages, institutions, shelf numbers, contents, and publications for MONB.XF.

Table 6: Institutions, shelf numbers, contents, and publications of pages without page numbers

for MONB.XF.

Table 7: Number of pages per work as a percentage of total number of pages in MONB.XF....189

Table 8: Pages, institutions, shelf numbers, contents, and publications for MONB.XM.

Table 9: Number of pages per work as a percentage of total number of pages in MONB.XM... 191

Table 10: Pages, institutions, shelf numbers, contents and publications for MONB.XV.

Table 11: Number of pages per work as a percentage of total number of pages in in MONB.XV.

Table 12: Pages, institutions, shelf numbers, contents, and publications for MONB.YJ.

Table 13: Pages, institutions, shelf numbers, contents, and publications for MONB.XL

Table 14: Number of intertexts found by Amélineau and Wiesmann in Canon 6.

Table 15: Number of intertexts per book of the OT found by Amélineau and Wiesmann in

Shenoute's Canon 6 
Table 16: Number of intertexts per book of the NT found by Amélineau and Wiesmann in

Shenoute's Canon 6.

Table 17: Pages, institutions, shelf numbers, and contents for MONB.BA.

Table 18: Institutions, shelf numbers, and contents of pages in MONB.BB. 206

Table 19: Number and percentage of intertexts found by Kuhn in Besa's works. 208

Table 20: Number of intertexts per book of the OT found by Kuhn. .209

Table 21: Number of intertexts per book of the NT found by Kuhn. 210

Table 22: Number of intertexts per author found by Kuhn in Besa's Letters and Sermons.

Table 23: Most frequent idiomatic text reuse pairs between Canon 6, Besa, and Psalms

Table 24: Summary of Levenshtein Distance, quotative index phrases, shared morphemes, and previous studies for quotations newly identified by TRACER (LD = Levenshtein Distance, $\mathrm{QIP}=$ quotative index phrase, $\mathrm{SM}=$ shared morphs, $\mathrm{K}=\mathrm{Kuhn}, \mathrm{A}=$ Amélineau, $\mathrm{B}=$ Behlmer, $\mathrm{Z}=$ Zoega, $\mathrm{W}=$ Wiesmann, $\mathrm{Y}=$ Young, $\mathrm{L}=$ Layton, $\mathrm{U}=$ Unpublished).

Table 25 Correspondences between Morpheus-based POS tagset and Coptic SCRIPTORIUM's fine POS tagset 


\section{List of figures}

Figure 1: Gradual increase in the frequency of the term "intertextuality" in SBL meeting abstract

books.

Figure 2: Increase in relative frequency of the terms "intertextuality" and "intertext" on Google

Books.

Figure 3: Page 125 (John 12:39-13:19) of the Luther Bible (Deutsche Bibelgesellschaft 2008). 50

Figure 4: Taxonomy of text reuse in TRACER. 70

Figure 5: Büchler's original taxonomy of major text reuses. .71

Figure 6: Potthast's taxonomy of text reuse. 72

Figure 7: Kirner-Ludwig and Zimmerman's taxonomy of text reuse. 73

Figure 8: MONB.BA p. 49, col. 2, 1. 1-11 with diplēs shown to the left of each line. 86

Figure 9: The Olde and Newe Testament (also known as the "Geneva Bible"), Geneva, 1560

(Finnegan 2011:85). 88

Figure 10: An upper half of a page from Pope Shenouda III 2016: 76. 89

Figure 11: Quotations marked with XML tags in BiblIndex (taken from Hue-Gay et al. 2017: 13)

Figure 12: Representation of MONB.XV p. 13 on the Virtual Manuscript Room of the CoptOT

project 122 
Figure 13: The corpus of Apophthegmata Patrum on the ANNIS portal. Users can search all verboids in the corpus using the ANNIS query language.

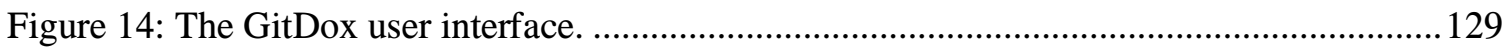

Figure 15: Importing TRACER results into ANNIS (taken from Miyagawa et al. 2018)........... 129

Figure 16: Outline of the pre-processing and processing stages.............................................. 130

Figure 17: Recognized letters by OCRopy in a processed image from Kuhn 1956a: 115

(Miyagawa et al. 2019: i137).

Figure 18: Sample OCRopy results.

Figure 19: Results of OCR accuracy against training iterations (courtesy of Kirill Bulert).

Figure 20: The Coptic NLP Service parsing a Coptic text morphologically and syntactically...150

Figure 21: TRACER workflow (courtesy of eTRAP). 151

Figure 22: Dot plot view in TRAViz. 158

Figure 23: Text reuse alignment by TRAViz. 159

Figure 24: Parallel view of TRAViz. 160

Figure 25: Structure of two overlapping quotations from Ps 82:16 (15 Budge; 83:15) and Ps 20:10 (9 Budge; 21:9) in Besa's Fragment 4/I/2. 


\section{Bibliography}

Aggarwal, Charu C., and Cheng Xiang Zhai. 2012. “An Introduction to Text Mining.” In Mining Text Data, edited by Charu C. Aggarwal and Cheng Xian Zhai, 1-10. Basel: Springer.

Aiken, Alex. 2010-2018. MOSS: A System for Detecting Software Similarity. Accessed September 11, 2021, https://theory.stanford.edu/ aiken/moss/.

Albrecht, Felix. 2018. “Zur Wirkungsgeschichte des Septuagintapsalters im ägyptischen Christentum. Die griechisch-koptischen Bilinguen.” In Die Septuaginta. Geschichte, Wirkung, Relevanz, edited by Martin Meiser, Michaela Geiger, Siegfried Kreuzer, and Marcus Sigismund, 481-95. Wissenschaftliche Untersuchungen zum Neuen Testament 405. Tübingen: Mohr Siebeck.

Allberry, Charles Robert Cecil. 1938. A Manichaean Psalm-Book. Manichaean Manuscripts in the Chester Beatty Collection 2. Stuttgart: W. Kohlhammer.

Allen, Graham. 2000. Intertextuality: The New Critical Idiom. London: Routledge.

Allenbach, Jean. 1975. Biblia patristica: Index des Citations et Allusions Bibliques dans la Littérature Patristique: 1: Des Origines à Clément d'Alexandrie et Tertullien. Vol. 1. Paris: Édition du Centre National de la Recherche Scientifique.

Allenbach, Jean, and André Pautler. 1977. Biblia Patristica: Index des Citations et Allusions Bibliques dans la Littérature Patristique: 2: Le Troisième Siècle: (Origène Excepté). Vol. 2. Paris: Édition du Centre National de la Recherche Scientifique.

1980. Biblia Patristica: Index des Citations et Allusions Bibliques dans la Littérature 
Patristique: 3: Origène. Vol. 3. Paris: Éd. du Centre National de la Recherche Scientifique.

1987. Biblia Patristica: Index des Citations et Allusions Bibliques dans la Littérature

Patristique: 4: Eusèbe de Césarée, Cyrille de Jérusalem, Épiphane de Salamine. Vol. 4. Paris:

Édition du Centre National de la Recherche Scientifique.

1991. Biblia Patristica: Index des Citations et Allusions Bibliques dans la Littérature

Patristique: 5: Basile de Césarée, Grégoire de Nazianze, Grégoire de Nysse, Amphiloque

d'Iconium. Vol. 5. Paris: Édition du Centre National de la Recherche Scientifique.

1995. Biblia Patristica: Index des Citations et Allusions Bibliques dans la Littérature

Patristique: 6: Hilaire de Poitiers, Ambroise de Milan, Ambrosiaster. Vol. 6. Paris: Édition du

Centre National de la Recherche Scientifique.

Al-Tukhi, Rushdi. 1991. "Rufa'il al-Tukhi." The Coptic Encyclopedia, edited by Aziz Suryal Atiya. vol.

7. $2067 b-68 b$.

Amélineau, Émile. 1888. Monuments pour Servir à l'Histoire de l'Égypte Chrétienne. Paris: Ernest Leroux.

1907. Euvres de Schenoudi, Texte Copte et Traduction Française. Vol. 1. 2 vols. Paris: Ernest Leroux.

1914. Euvres de Schenoudi, Texte Copte et Traduction Française. Vol. 2. 2 vols. Paris: Ernest

Leroux.

Atanassova, Diliana. 2010a. "Das verschollene koptisch-sahidische Typikon-Fragment aus Venedig:

Ein liturgisches Dokument aus dem Schenute-Kloster in Oberägypten.” Oriens Christianus 94:

$105-22$. 
2010b. "Paper Codices with Liturgical Typika from the White Monastery." Coptica 9: 1-23.

Aufrère, Sydney H. 2006. “Chénouté: Hellénisme ou Démotisme.” Lingua Aegyptia 14: 265-80.

Aufrère, Sydney H. and Nathalie Bosson. 2005. Guillaume Bonjour: Elementa Linguae Copticae: Grammaire Inédite du XVIIe Siècle, with a preface by Ariel Shisha Halevy and appendix by Enzo Lucchesi. Cahiers d'Orientalisme 24. Geneva: P. Cramer.

Bacot, Seÿna. 2009. Ostraca Grecs et Coptes de Tell Edfou. Bibliothèque d'Études Coptes 19. Le Caire: Institut Français d'Archéologie Orientale.

Bagnall, Roger S. 2008. "Models and Evidence in the Study of Religion in Late Roman Egypt.” In From Temple to Church: Destruction and Renewal of Local Cultic Topography in Late Antiquity, edited by Johannes Hahn, Stephen Emmel, and Ulrich Gotter, 24-43. Religions in the GraecoRoman World 163. Leiden: Brill.

Bagnall, Roger S. and Raffaella Cribiore. 2006. Women's Letters from Ancient Egypt, 300 BC-AD 800. With contributions by Evie Ahtaridis. Ann Arbor, MI: University of Michigan Press.

Bagnall, Roger S., Dominic W. Rathbone, and Evie Ahtaridis. 2004. Egypt from Alexander to the Early Christians: An Archaeological and Historical Guide. Los Angeles, California: Getty Publications.

Bąk, Tomasz. 2014. Il Proto-Isaia in Copto-Saidico. Edizione Critica sulla Base di sa52 (M 568) e di Altri Testimoni. Estratto della Dissertazione per il Dottorato in Studi dell'Oriente Antico. Rome: Pontificio Istituto Biblico. 2015. "Shenute e le Sue Citazioni dei Salmi nell’Omelia: Ad Philosophum Gentilem." The Biblical Annals 5 (1): 59-79. 
Bakhtin, Mikhail M. 1984. Problems of Dostoevsky's Poetics. Translated by Caryl Emerson. Theory and History of Literature 8. Minneapolis, Minnesota: University of Minnesota Press.

Bär, Daniel, Torsten Zesch, and Iryna Gurevych. 2012. “Text Reuse Detection Using a Composition of Text Similarity Measures.” In Proceedings of COLING 2012: Technical Papers, edited by Martin Kay and Christian Boitet, revised preprint, 167-84. Mumbai: The COLING 2012 Organizing Committee, Indian Institute of Technology Bombay.

Barthes, Roland. 1968. “La Mort de l’Auteur.” Manteia 5: 12-17.

Becker, Sina. 2008. Auf den Spuren antiker Rhetorik in den Briefen Schenutes. Master thesis, Münster: Westfälische Wilhelms-Universität Münster.

Behlmer, Heike. 1998. "Visitors to Shenoute's Monastery." In Pilgrimage and Holy Space in Late Antique Egypt, edited by David Frankfurter, 353-83. Religions in the Graeco-Roman World 134. Leiden: Brill. 2002. "The City as Metaphor in the Works of two Panopolitans: Shenoute and Besa." In Perspectives on Panopolis: An Egyptian Town from Alexander the Great to the Arab Conquest: Acts from an International Symposium Held in Leiden on 16, 17 and 18 December 1998, edited by Egberts, Arthur, B. P. Muhs, and Jacques van der Vliet, 13-27. Leiden: Brill. . 2004 (unpublished). Heilige Schriften als rhetorische Waffe: Autoritative Texte und ihre literarische Verarbeitung im Werk des ägyptischen Klostervorstehers Besa.

2008. "Do Not Believe Every Word like the Fool...! Rhetorical Strategies in Shenoute, Canon 6." In Christianity and Monasticism in Upper Egypt, Vol. 1: Akhmim and Sohag, edited by Gawdat Gabra and Hany N. Takla, 1-12. Cairo: American University in Cairo Press. 
2009. “'Our Disobedience Will Punish Us...’: The Use of Authoritative Quotations in the Writings of Besa." In Texte-Theben-Tonfragmente. Festschrift für Günter Burkard, edited by Dieter Kessler, Regine Schulz, Martina Ullmann, Alexandra Verbovsek, and Stefan Wimmer,

37-54. Wiesbaden: Harrassowitz Verlag.

2016. "Die Bibel im koptischen Mönchtum der Spätantike.” In Zwischen Exegese und Religiöser Praxis: Heilige Texte von der Spätantike bis zum Klassischen Islam, edited by Peter Gemeinhardt, 143-76. Tübingen: Mohr Siebeck.

. 2017. "The Use of the Psalms in Shenoute's Tractate He Who Sits Upon His Throne." In From Gnostics to Monastics. Studies in Coptic and Early Christianity in Honor of Bentley Layton, edited by David Brakke, Stephen J. Davis, and Stephen Emmel, 315-30. Orientalia Lovaniensia Analecta 263. Leuven: Peeters.

. 2019. "Schenute von Atripe.” In Reallexikon für Antike und Christentum: Sachwörterbuch zur Auseinandersetzung des Christentums mit der Antiken Welt, edited by Georg Schöllgen, Heinzgerd Brakmann, Sible de Blaauw, Therese Fuhrer, Hartmut Leppin, Winrich Löhr, HeinzGünther Nesselrath, Maren Niehoff, and Ilinca Tanaseanu-Döbler, 824-36. Stuttgart: Anton Hiersemann.

Behlmer, Heike, and Frank Feder. 2017. "The Complete Digital Edition and Translation of the Coptic Sahidic Old Testament. A New Research Project at the Göttingen Academy of Sciences and Humanities.” Early Christianity 8: 97-107.

Bell, David N. 1983. The Life of Shenoute: Introduction, Translation, and Notes. Cistercian Studies 73. Kalamazoo, Michigan: Cistercian Publications. 
Berry, David M. 2012. “Introduction: Understanding the Digital Humanities." In Understanding Digital Humanities, edited by David N. Berry, 1-20. London: Palgrave Macmillan.

Berry, Michael J. A., and Gordon S. Linoff. 2004. Data Mining Techniques: For Marketing, Sales, and Customer Relationship Management. New York: John Wiley \& Sons.

Bird, Michael F. and Joel Willitts, eds. 2011. Paul and the Gospels: Christologies, Conflicts, and Convergences. London: Bloomsbury T \& T Clark.

Bodard, Gabriel, and Simona Stoyanova. 2016. "Epigraphers and Encoders: Strategies for Teaching and Learning Digital Epigraphy." In Digital Classics Outside the Echo-Chamber: Teaching, Knowledge Exchange \& Public Engagement, edited by Gabriel Bodard and Matteo Romanello, 51-68. London: Ubiquity Press.

Black, Paul E. 1999. “Levenshtein Distance.” In Dictionary of Algorithms and Data Structures [online], edited by Paul E. Black, accessed December 5, 2021, https://www.nist.gov/dads/HTML/Levenshtein.html.

Blanke, Louise. 2019. An Archaeology of Egyptian Monasticism: Settlement, Economy and Daily Life at the White Monastery Federation. Yale Egyptological Publications 2. New Haven: Yale Egyptological Institute.

Boisvert, Mathieu. 1992. "A Comparison of the Early Forms of Buddhist and Christian Monastic Traditions.” Buddhist-Christian Studies 12: 123-41.

Bolman, Elizabeth S. 2016. The Red Monastery Church: Beauty and Asceticism in Upper Egypt. New Haven, Connecticut: Yale University Press.

Bolman, Elizabeth S., Stephen J. Davis, and Gillian Pyke. 2010. “Shenoute and a Recently Discovered 
Tomb Chapel at the White Monastery." Journal of Early Christian Studies 18 (3): 453-62.

Boon, Amand. 1932. Pachomiana Latina: Règle et Épîtres de s. Pachôme, Épître de s. Théodore et

'Liber' de s. Orsiesius. Bibliothèque de la Revue d'Histoire Ecclésiastique 7. Louvain: Universiteitbibliotheek.

Borges, Jorge Luis. 1977. The Book of Sand. Translated by Norman Thomas di Giovanni. Boston, MA:

E. P. Dutton.

1979. The Book of Sand. Translated by Norman Thomas di Giovanni and Alastair Reid.

London: Penguin Books.

2001. The Book of Sand and Shakespeare's Memory. Translated by Andrew Hurley. London:

Penguin Classics.

—. 2011. El Libro de Arena. Reprint ed. Barcelona: Debols!llo.

Boud'hors, Anne. 2013. Le Canon 8 de Chénouté. 2 vols. Bibliothèque d’Études Coptes 21. Le Caire: Institut Français d'Archéologie Orientale.

—. 2017. "Coptic Church Fathers." In Textual History of the Bible: The Hebrew Bible, Volume

1C: Writings, edited by Armin Lange and Emanuel Tov, 768-70. Leiden and Boston: Brill.

Bouriant, Urbain. 1889. “Rapport au Ministre de l'Instruction Publique sur une Mission dans la HauteÉgypte (1884-1885). In Mémoires publiés par les membres de la Mission Archéologique Française au Caire, edited by Gaston Maspero, 367-408. Paris: Ernest Leroux.

du Bourguet, S.J., Pierre. 1991. "Wiesmann, Hermann (1871-1948).” In The Coptic Encyclopedia, edited by Aziz Suryal Atiya, 7:2321. New York: Macmillan.

Brakke, David. 1994. "Canon Formation and Social Conflict in Fourth-Century Egypt: Athanasius of 
Alexandria's Thirty-Ninth Festal Letter." Harvard Theological Review 87 (4): 395-419.

2004. "Shenoute, Weber, and the Monastic Prophet: Ancient and Modern Articulations of Ascetic Authority." In Foundations of Power and Conflicts of Authority in Late-Antique Monasticism: Proceedings of the International Seminar Turin, December 2-4, 2004, edited by Alberto Camplani and Giovanni Filoramo, 47-74. Orientalia Lovaniensia Analecta 157. Leuven \& Dudley, Massachusetts: Peeters Publishers.

2009a. Demons and the Making of the Monk: Spiritual Combat in Early Christianity. Cambridge, Massachusetts: Harvard University Press.

2009b. Evagrius of Pontus, Talking Back: Antirrhêtikos: A Monastic Handbook for Combating

Demons. Kalamazoo, Michigan: Cistern Publications.

Brakke, David, and Andrew Crislip. 2015. Selected Discourses of Shenoute the Great: Community, Theology, and Social Conflict in Late Antique Egypt. Cambridge: Cambridge University Press. Bringhurst, Robert. 1997. The Elements of Typographic Style. Second ed. Vancouver: Hartley \& Marks Publishers.

Broder, Andrei Z. 1997. On the Resemblance and Containment of Documents. In Proceedings of the Compression and Complexity of SEQUENCES 1997: Positano, Amalfitan Coast: Salerno, Italy: June 11-13, 1997, edited by Bruno Carpentieri, Alfredo De Santis, Ugo Vaccaro, and James A. Storer, 21-9. Washington, D.C.: IEEE Computer Society.

Broder, Andrei Z., Steven C. Glassman, Mark S. Manasse, and Geoffrey Zweig. 1997. "Syntactic Clustering of the Web." Computer Networks and ISDN Systems 29 (8-13): 1157-66.

Brooks Hedstrom, Darlene L., Elizabeth S. Bolman, Mohammed Abdel Rahim, Saad Mohammed, 
Dawn McCormack, Tomasz Herbich, Gillian Pyke, Louise Blanke, Tracy Musacchio, and Mohammed Khalifa. 2011. “The White Monastery Federation Project: Survey and Mapping at the Monastery of Apa Shenoute (Dayr al-Anba Shinūda), Sohag, 2005-2007.” Dumbarton Oaks Papers 65: 333-64.

Büchler, Marco. 2008. Medusa: Performante Textstatistiken auf großen Textmengen: Kookkurrenzanalyse in Theorie und Anwendung. Saarbrücken: VDM Verlag. 2013. Informationstechnische Aspekte des Historical Text Re-use. Doctoral thesis, Universität Leipzig.

Büchler, Marco, Philip R. Burns, Martin Müller, Emily Franzini, and Greta Franzini. 2014. "Towards a Historical Text Re-Use Detection.” In Text Mining, edited by Michael W. Berry and Jacob Kogan, 221-38. Basel: Springer.

Büchler, Marco, and Annette Geßner. 2009. "Citation Detection and Textual Reuse on Ancient Greek Texts." Linguistik, Humboldt Universität zu Berlin. Accessed September 12, 2021, https://www.linguistik.hu-berlin.de/en/institut-en/professuren-en/korpuslinguistik/eventsen/nehdfg/pdf/buechler-reuse.

Büchler, Marco, Annette Geßner, Gerhard Heyer, and Thomas Eckart. 2010. "Detection of Citations and Textual Reuse on Ancient Greek Texts and Its Applications in the Classical Studies: eAQUA Project." In Proceedings of Digital Humanities 2010 King's College London, 7-10 July 2010, edited by Elena Pierazzo. 113-14. London: King’s College London.

Büchler, Marco, Gerhard Heyer, and Sabine Gründer. 2008. “eAQUA -Bringing Modern Text Mining Approaches to Two Thousand Years Old Ancient Texts." In Proceedings of E-Humanities-An 
Emerging Discipline, Workshop at the 4th IEEE International Conference on e-Science, eHumanities - an emerging discipline. Online ed. Accessed September 12, 2021, https://citeseerx.ist.psu.edu/viewdoc/download?doi=10.1.1.711.6697\&rep=rep1\&type=pdf.

Budge, E. A. Wallis. 1898. The Earliest Known Coptic Psalter: The Text in the Dialect of Upper Egypt, Edited from the Unique Papyrus Codex Oriental 5000 in the British Museum. London: Kegan Paul, etc.

-1912. Coptic Biblical Texts in the Dialect of Upper Egypt. London: British Museum.

Burdick, Anne, Johanna Drucker, Peter Lunenfeld, Todd Presner, and Jeffrey Schnapp. 2012. Digital_Humanities. Cambridge, Massachusetts: MIT Press.

Burton-Christie, Douglas. 1993. The Word in the Desert. Scripture and the Quest for Holiness in Early Christian Monasticism. New York and Oxford: Oxford University Press.

Busa, S.J., Roberto. 1951. Sancti Thomae Aquinatis Hymnorum Ritualium Vara Specimina Concordantiarum: A First Example of Word Index Automatically Compiled and Printed by $I B M s$

Buzi, Paola. 2009. Catalogo dei Manoscritti Copti Borgiani Conservati Presso la Biblioteca Nazionale “Vittorio Emanuele III" di Napoli: Con un Profilo Scientifico di Stefano Borgia e Georg Zoega e una Breve Storia della Formazione della Collezione Borgiana. Accademia dei Lincei Classe di scienze Morali, Storiche e Filologiche - Memorie, Serie IX, Volume XXV, Fascicolo 1. Roma: Accademia Nazionale dei Lincei.

2015. "The Catalogus Codicum Copticorum Manu Scriptorum qui in Museo Velitris Adservantur: Genesis of a masterpiece.” In The Forgotten Scholar: Georg Zoёga (1755-1809): 
At the Dawn of Egyptology and Coptic Studies, edited by Karen Ascani, Paola Buzi, and Daniela

Picchi, 216-23. Culture and History of the Ancient Near East 74. Leiden and Boston: Brill. DOI: 10.1163/9789004290839_022.

Cain, Andrew. 2016. The Greek Historia Monachorum in Aegypto: Monastic Hagiography in the Late Fourth Century. Oxford: Oxford University Press.

Camplani, Alberto. 2003. Atanasio di Alessandria, Lettere Festali: Anonimo: Indice delle Lettere Festali. Milano: Paoline.

Casey, Christian. 2016. “Anti-Intellectualism in Shenoute's Life.” Christian Casey, the Egyptologist. Accessed September 12, 2021, https://christiancasey.github.io/Casey,\%20Christian\% 20(2016)\%20Anti-Intellectualism\%20in\%20Shenoute's\%20Life.pdf.

Celano, Giuseppe GA, Gregory Crane, and Saeed Majidi. 2016. "Part of Speech Tagging for Ancient Greek." Open Linguistics 2 (1): 393-99.

Choat, Malcolm. 2013. "Monastic letter collections in Late Antique Egypt: Structure, Purpose, and Transmission." In Cultures in Contact: Transfer of Knowledge in the Mediterranean Context: Selected Papers, edited by Sofía Torallas Tovar and Juan Pedro Monferrer-Sala, 73-90. Cordoba: CNERU (Cordoba Near Eastern Research Unit) \& Beirut: CEDRAC (Centre de Documentation et de Recherches Arabes Chrétiennes) - Oriens Academic.

Choat, Malcolm and Maria Chiara Giorda. 2017. "Communicating Monasticism: Reading and Writing Monastic texts in Late Antique Egypt." In Writing and communication in early Egyptian monasticism, edited by Malcolm Choat and Maria Chiara Giorda, 5-16. Leiden and Boston: Brill. 
Chomsky, Noam. 1956. "Three Models for the Description of Language." IRE Transactions on Information Theory 2 (3): 113-24.

-1965. Aspects of the Theory of Syntax. Cambridge, MA: M.I.T. Press.

Coffee, Neil, Jean-Pierre Koenig, Shakthi Poornima, Christopher W. Forstall, Roelant Ossewaarde, and Sarah L Jacobson. 2012. “The Tesserae Project: Intertextual Analysis of Latin Poetry.” Literary and Linguistic Computing 28 (2): 221-28.

Coffee, Neil, Jean-Pierre Koenig, Shakthi Poornima, Roelant Ossewaarde, Christopher Forstall, and Sarah Jacobson. 2012. "Intertextuality in the Digital Age." Transactions of the American Philological Association 142 (2): 383-422.

Comfort, Philip Wesley. 2005. Encountering the Manuscripts: An Introduction to New Testament Paleography \& Textual Criticism. Nashville, Tennessee: B\&H Publishing Group.

Coquin, René-Georges, Maurice Martin, Peter Grossmann, and Hans Georg Severin. 1991a. "Dayr Anba Shinudah.” In The Coptic Encyclopedia, edited by Aziz Suryal Atiya, 3:761-70. New York: Macmillan.

Coquin, René-Georges, Maurice Martin, Hans Georg Severin, and Peter Grossmann. 1991b. "Dayr Anba Bishoi (Suhaj).” In The Coptic Encyclopedia, edited by Aziz Suryal Atiya, 2:736-40. New York: Macmillan.

Crislip, Andrew. 2009. "Shenoute of Atripe on Christ the Physician and the Cure of Souls." Le Muséon $122(3-4): 247-77$.

2016. “Shenoute Studies.” In Coptic Society, Literature and Religion from Late Antiquity to Modern Times: Proceedings of the Tenth International Congress of Coptic Studies, Rome, 
September 17th-22nd, 2012, and Plenary Reports of the Ninth International Congress of Coptic

Studies, Cairo, September 15th-19th, edited by Paola Buzi, Alberto Camplani, and Federico

Contardi, 1:335-64. Orientalia Lovaniensia Analecta 247. Leuven, Paris, and Bristol, CT:

Peeters.

Crisler, Channing L. 2021. An Intertextual Commentary on Romans, Volume 1. Eugene, OR: Pickwick Publications.

Cristea, Hans-Joachim. 2011. Schenute von Atripe: Contra Origenistas. Studien und Texte zu Antike und Christentum 60. Münster: Mohr Siebeck.

Cromwell, Jennifer. 2013. “A Coptic Epistolary Exercise from Wadi Sarga.” The Journal of Egyptian Archaeology 99 (1): 272-75.

. 2015. "Coptic Writing Exercises in the Petrie Museum with a Concordance of Its Published Coptic Texts." Zeitschrift für Papyrologie und Epigraphik 195: 205-21.

Crum, Walter E. 1905. Catalogue of the Coptic Manuscripts in the British Museum. London: British Museum. Accessed November 11, 2021, https://archive.org/details/catalogueofcopti00brituoft. Dällenbach, Lucien. 1976. “Intertexte et Autotexte.” Poétique 27: 282-96.

Davidson, Elizabeth. 2018. “Shenoute.” In The Oxford Dictionary of Late Antiquity, edited by Oliver Nicholson. Oxford: Oxford University Press.

Davis, Stephen J. 2008. Coptic Christology in Practice: Incarnation and Divine Participation in Late Antique and Medieval Egypt. Oxford: Oxford University Press.

Deutsche Bibelgesellschaft. 2008. Die Bibel nach der Übersetzung Martin Luthers. Stuttgart: Deutsche Bibelgesellschaft. 
2017. Die Bibel nach Martin Luthers Übersetzung: Lutherbibel, revidiert 2017: mit

Apokryphen. Stuttgart: Deutsche Bibelgesselschaft.

Dell, Katherine and Will Kyne, eds. 2016. Reading Ecclesiastes Intertextually. London: Bloomsbury T\&T Clark.

. 2018. Reading Proverbs Intertextually. London: Bloomsbury T \& T Clark.

- 2018. Reading Job Intertextually. London: Bloomsbury T \& T Clark.

Dilley, Paul. 2017. "From Textual to Ritual Practice: Written Media and Authority in Shenoute's Canons." In Writing and Communication in Early Egyptian Monasticism, edited by Malcolm Choat and Maria Chiara Giorda, 73-107. Leiden: Brill.

Dods, Marcus. 1887. “Augustine of Hippo. 'The City of God."” In St. Augustin's City of God and Christian Doctrine, edited by Philip Schaff, 2:26. A Select Library of the Nicene and PostNicene Fathers of the Christian Church, First Series. Buffalo, NY: Christian Literature Company.

Egberts, Arthur, B. P. Muhs, and Jacques van der Vliet, eds. 2002. Perspectives on Panopolis: An Egyptian Town from Alexander the Great to the Arab Conquest: Acts from an International Symposium Held in Leiden on 16, 17 and 18 December 1998. Leiden: Brill.

El-Sayed, Rafed and Yahya El-Masry. 2012. Athribis I. Cairo: Institut Français d'Archéologie Orientale. El-Sayed, Rafed and Konstantin C. Lakomy. 2017. Petrie's 1907/08 Dig Season Near Sūhāğ II: The Corpus of Finds: 1 Ceramic Vessels and Sherds, Studia Panopolitana: Occasional Paper 3. Wiesbaden: Reichert Verlag.

Emmel, Stephen. 1995. “Theophilus's Festal Letter of 401 as Quoted by Shenoute.” In Divitiae Aegypti: 
Koptologische und verwandte Studien zu Ehren von Martin Krause, edited by Cäcilia Fluck and Martin Krause, 93-98. Wiesbaden: Dr. Ludwig Reichert Verlag.

2004a. "Coptic Studies before Kircher." In Coptic Studies on the Threshold of a New Millennium: Proceedings of the Seventh International Congress of Coptic Studies, Leiden, August 27-September 2, 2000, edited by Mat Immerzeel and Jacques van der Vliet, 1-11. Orientalia Lovaniensia Analecta 133. Leuven: Peeters.

.2004b. "Shenoute the Monk: The Early Monastic Career of Shenoute the Archimandrite." In Il Monachesimo tra Eredità e Aperture: Atti del Simposio "Testi e Temi nella Tradizione del Monachesimo Cristiano" per il 50 Anniversario dell'Istituto Monastico di Sant'Anselmo, Roma, 28 Maggio- $1^{\circ}$ Giugno 2002, edited by Maciej Bielawski and Daniel Hombergen, 15174. Analecta Monastica 8. Rome: Centro Studi Sant Anselmo. 2004c. Shenoute's Literary Corpus. 2 vols. Leuven: Peeters.

. 2007. "Coptic Literature in the Byzantine and Early Islamic World." In Egypt in the Byzantine World, 300-700, edited by Roger S. Bagnall, 83-102. Cambridge: Cambridge University Press. 2008. "Shenoute's Place in the History of Monasticism". In Christianity and Monasticism in Upper Egypt. I. Akhmim and Sohag, edited by Gawdat Gabra and Hany N. Takla, 31-46. Cairo: American University in Cairo Press.

. 2016. "Editing Shenoute, Old Problems, New Prospects: The Date of Shenoute's Death.” In Coptic Society, Literature and Religion from Late Antiquity to Modern Times: Proceedings of the Tenth International Congress of Coptic Studies, Rome, September 17th-22th, 2012, and Plenary Reports of the Ninth International Congress of Coptic Studies, Cairo, September 15th- 
19th, 2008, edited by Paola Buzi, Alberto Camplani, and Federico Contardi, 2:937-44.

Orientalia Lovaniensia Analecta 247. Leuven, Paris, and Bristol, CT: Peeters.

Emmel, Stephen, and Cornelia Eva Römer. 2008. "The Library of the White Monastery in Upper Egypt". In Spätantike Bibliotheken: Leben und Lesen in den frühen Klöstern Ägyptens, edited by Harald Froschauer and Cornelia Eva Römer, 5-14. Nilus: Studien zur Kultur Ägyptens und des Vorderen Orients 14. Wien: Phoibos.

Emmenegger, Gregor. 2007. Der Text des koptischen Psalters aus al-Mudil: ein Beitrag zur Textgeschichte der Septuaginta und zur Textkritik koptischer Bibelhandschriften, mit der kritischen Neuausgabe des Papyrus 37 der British Library London (U) und des Papyrus 39 der Leipziger Universitätsbibliothek (2013). Texte und Untersuchungen zur Geschichte der altchristlichen Literatur 159. Berlin: Walter de Gruyter.

ESV Bible Translation Committee. 2009. The English Standard Version Bible with Apocrypha. Oxford: Oxford University Press.

Evans, Craig A., B.J. Oropeza, and Paul T. Sloan, eds. 2020. New Studies in Textual Interplay. London: Bloomsbury T \& T Clark.

Fauconnier, Gilles. 1994. Mental Spaces: Aspects of Meaning Construction in Natural Language. Cambridge: Cambridge University Press.

Fauconnier, Gilles, and Mark Turner. 2008. The Way We Think: Conceptual Blending and the Mind's Hidden Complexities. New York: Basic Books.

Fayyad, Usama M, Gregory Piatetsky-Shapiro, and Padhraic Smyth. 1996. "From Data Mining to Knowledge Discovery: An Overview." Advances in Knowledge Discovery and Data Mining, 
edited by Fayyad, Usama M, Gregory Piatetsky-Shapiro, Padhraic Smyth, and Ramasamy Uthurusamy, 1-36. Cambridge, Massachusetts: American Association for Artificial Intelligence Press.

Fayyad, Usama, Gregory Piatetsky-Shapiro, and Padhraic Smyth. 1996. "The KDD Process for Extracting Useful Knowledge from Volumes of Data." Communications of the ACM 39 (11): $27-34$.

Feder, Frank. 1998. "Die systematische Nummerierung der Handschriften des Alten Testaments zur Edition der koptisch-sahidischen Septuaginta." In Zeit und Geschichte in der koptischen Frömmigkeit bis zum 8. Jahrhundert: Beiträge zur VIII. Internationalen Halleschen Koptologentagung vom 15.-18. Mai 1998, edited by Walter Beltz and Jürgen Tubach, 26:3336. Hallesche Beiträge zur Orientwissenschaft. Halle (Saale): Martin-Luther-Universität HalleWittenberg.

. 2001. "Der Wert einer lexikologischen Untersuchung der koptischen Bibelübersetzung für die ägyptische Lexikographie.” Zeitschrift für Ägyptische Sprache und Altertumskunde 128: 7-23. 2002. Biblia Sahidica: Ieremias, Lamentationes (Threni), Epistula Ieremiae et Baruch, Texte und Untersuchungen. Berlin and New York: de Gruyter.

. 2007. "Die koptische Übersetzung des Alten und Neuen Testaments im 4. Jahrhundert.” In Stabilisierung und Profilierung der koptischen Kirche im 4. Jahrhundert: Beiträge zur X. Internationalen Halleschen Koptologentagung 2006, edited by Jürgen Tubach and Sophia G. Vashalomidze, 65-93. Hallesche Beiträge zur Orientwissenschaft 44. Halle (Saale): MartinLuther-Universität Halle-Wittenberg. 
2016. "Coptic Translations." In Textual History of the Bible. The Hebrew Bible, Vol. 1A:

Overview Articles, edited by Armin Lange and Emanuel Tov, 331-45. Leiden and Boston, Massachusetts: Brill.

2017. “Isaiah, Jeremiah, Ezekiel.” In Textual History of the Bible. The Hebrew Bible, Vol. 1B:

Pentateuch, Former and Latter Prophets, edited by Armin Lange and Emanuel Tov, 283-285.

Leiden and Boston: Brill.

. 2020a. "The Canonical Histories of the Deuterocanonical Texts: The Coptic Canon." In Textual

History of the Bible: The Deuterocanonical Scriptures: Vol. 2A: Overview Articles, edited by

Frank Feder, Matthias Henze, and Mika Pajunen, 424-35. Leiden and Boston: Brill.

. 2020b. "Psalms 151-155: Coptic." In Textual History of the Bible: The Deuterocanonical

Scriptures: Vol.2C: Jubilees, Judith, Maccabees, Prayer of Manasseh, Psalms 151-155, Psalms

and Odes of Solomon, Tobit, Wisdom of Solomon; Appendix: Odes, edited by Frank Feder,

Matthias Henze, and Mika Pajunen, 312-14. Leiden and Boston: Brill.

Fellbaum, Christiane. 2005. "WordNet and Wordnets." In Encyclopedia of Language and Linguistics, edited by Keith Brown, 2nd ed., 665-70. Oxford: Elsevier.

Ficker, Gerhard. 1906. “Eine Sammlung von Abschwörungsformeln.” Zeitschrift für Kirchengeschichte 27: $443-64$.

Finnegan, Ruth. 2011. Why Do We Quote? The Culture and History of Quotation. Cambridge: Open Book Publishers.

Forstall, Christopher W. and Walter J. Scheirer. 2019. Quantitative Intertextuality Analyzing the Markers of Information Reuse. Cham: Springer. 
Franzini, Greta, Emily Franzini, and Marco Büchler. 2016. “Historical Text Reuse: What Is It?” eTRAP. Accessed September 12, 2021, http://www.etrap.eu/historical-text-re-use/.

Franzini, Greta, Maria Moritz, Marco Passarotti, and Marco Büchler. 2018. "Using and Evaluating TRACER for an Index Fontium Computatus of the Summa Contra Gentiles of Thomas Aquinas.” In Proceedings of the Fifth Italian Conference on Computational Linguistics (CLiC-it) 2018: Torino, Italy, December 10-12, edited by Elena Cabrio, Alessandro Mazzei, and Fabio Tamburini, 199-205. AI*IA Series 2253, CEUR Workshop Proceedings ISSN 1613-0073. Turin: CliC-it 2018. Accessed September 12, 2021, http://ceur-ws.org/Vol-2253/paper22.pdf.

Funk, Wolf-Peter. 1988. Dialects Wanting Homes: A Numerical Approach to the Early Varieties of Coptic. In Historical Dialectology, Regional and Social, edited by Jacek Fisiak, 149-92. Trends in Linguistics, Studies and Monographs 37. Berlin: Mouton de Gruyter.

__ 1991. "Formen und Funktionen des interlokutiven Nominalsatzes in den koptischen Dialekten." Langues Orientales Anciennes Philologie et Linguistique 3: 57-60.

Gabra, Gawdat. 1995. Der Psalter im oxyrhynchitischen (mesokemischen/mittelägyptischen) Dialekt. Abhandlungen des Deutschen Archäologischen Instituts Kairo, Koptische Reihe 4. Heidelberg: Heidelberger Orientverlag.

Gabra, Gawdat, and Hany N. Takla. 2008. "Biblical Manuscripts of the Monastery of St. Shenoute the Archimandrite." In Christianity and Monasticism in Upper Egypt: I. Akhmim and Sohag, edited by Gawdat Gabra and Hany N. Takla.155-67. Cairo: The American University in Cairo Press. Gardner, Iain, ed. 2007. Kellis Literary Texts. Vol. 1. Dakhleh Oasis Project Monograph 4. London: Oxbow Books. 
, ed. 2008. Kellis Literary Texts. Vol. 2. Dakhleh Oasis Project Monograph 15. London: Oxbow Books.

Garitte, Gérard. 1937. “A Propos des Lettres de S. Antoine l’Ermite.” Le Muséon 52: 11-31.

Gemeinhardt, Peter. 2013. Antonius: Der erste Mönch. Leben-Lehre-Legende. Munich: Verlag C.H. Beck.

2018. Vita Antonii. Fontis Christiani 69. Freiburg: Herder.

Genette, Gérard. 1979. Introduction à l'Architexte. Paris: Seuil.

—1982. Palimpsestes; la Littérature au Second Degré. Paris: Seuil.

Goehring, James M. 1986. The Letter of Ammon and Pachomian Monasticism. Patristische Texte und Studien im Auftrag der Patristischen Kommission der Akademien der Wissenschaften in der Bundesrepublik Deutschland herausgegeben von K. Aland und W. Schneemelcher, Band 27. Berlin and New York: Walter de Gruyter.

Gorman Jr., Daniel. 2020. "St. Shenouda the Archimandrite Coptic Orthodox Monastery of Henrietta, N.Y., and the Coptic Orthodox Church of Ss. Peter and Paul.” Digitizing Rochester's Religions: A Public History Project. Accessed November 11, 2021, https://digrocreligions.org/sites/stshenouda/.

Graham, Tony. 2000. Unicode: A Primer. Foster City, CA: IDG Books Worldwide, Inc.

Griffitts, Troy. 2017. Software for the Collaborative Editing of the Greek New Testament. PhD thesis, University of Birmingham.

Griggs, C. Wilfred. 1990. Early Egyptian Christianity: From Its Origins to 451 CE. Leiden: Brill. Grossmann, Peter. 2004. “Zum Grab des Schenute.” Journal of Coptic Studies 6: 85-105. 
Güldemann, Tom. 2008. Quotative Indexes in African Languages: A Synchronic and Diachronic Survey. Empirical Approaches to Language Typology 34. Berlin: De Gruyter Mouton.

Hahn, Johannes. 2004. Gewalt und religiöser Konflikt: Studien zu den Auseinandersetzungen zwischen Christen, Heiden und Juden im Osten des Römischen Reiches (von Konstantin bis Theodosius II.). Berlin: Akademie Verlag GmbH.

Hamilton, Alastair. 2006. The Copts and the West, 1439-1822: The European Discovery of the Egyptian Church. Oxford-Warburg Studies 200. Oxford: Oxford University Press.

Harmless, William. 2004. Desert Christians: An Introduction to the Literature of Early Monasticism. Oxford: Oxford University Press.

Haspelmath, Martin. 2014. “A Grammatical Overview of Egyptian and Coptic.” In Egyptian-Coptic Linguistic in Typological Perspective, edited by Eitan Grossman, Tonio Sebastian Richter, and Martin Haspelmath, 103-44. Empirical Approaches to Language Typology 55. Berlin: De Gruyter Mouton.

Hays, Richard B. 2017. Echoes of Scripture in the Gospels. Reprint ed. Waco, TX: Baylor University Press.

Horn, Jürgen. 2000. “Die koptische (sahidische) Überlieferung des alttestamentlichen Psalmenbuches: Versuch einer Gruppierung der Textzeugen für die Herstellung des Textes.” In Der SeptuagintaPsalter und seine Tochterübersetzungen Symposium in Göttingen 1997, edited by Anneli Aejmelaeus and Udo Quast, 97-106. Abhandlungen der Akademie der Wissenschaften in Göttingen, Philologisch-Historische Klasse, Folge 3, 320; Mitteilungen des SeptuagintaUnternehmens 24. Göttingen: Vandenhoeck \& Ruprecht. 
Hibbard, Todd J. 2006. Intertextuality in Isaiah 24-27: The Reuse and Evocation of Earlier Texts and Traditions. Forschungen zum Alten Testament 2. Reihe 16. Tübingen: Mohr Siebeck.

Houston, Keith. 2013. Shady Characters: The Secret Life of Punctuation, Symbols, and Other Typographical Marks. New York: WW Norton \& Company.

Hue-Gay, Elysabeth, Laurence Mellerin, and Emmanuelle Morlock. 2017. "TEI-Encoding of Text Reuses in the BIBLINDEX Project." Journal of Data Mining and Digital Humanities, episciences.org, 2017, Special Issue on Computer-Aided Processing of Intertextuality in Ancient Languages. 1-19. Accessed September 11, 2021, https://hal.archivesouvertes.fr/halshs-01543050v2.

Jänicke, Stefan, Annette Geßner, Greta Franzini, Melissa Terras, Simon Mahony, and Gerik Scheuermann. 2015. “Traviz: A Visualization for Variant Graphs.” Digital Scholarship in the Humanities 30 (Supplement 1): i83-99.

Jockers, Matthew L. 2013. Macroanalysis: Digital Methods and Literary History. Champaign, Illinois: University of Illinois Press.

Juvan, Marko. 2008. History and Poetics of Intertextuality. West Lafayette, Indiana: Purdue University Press.

Karvalics, László Z. 2009. Information Society Dimensions. Szeged: JATEPress (Szegedi Tudományegyetem kiadója).

Kasser, Rodolophe. 1991. “Dialect P (or Proto-Theban).” In The Coptic Encyclopedia, edited by Aziz Suryal Atiya, 8:82a-87b. New York: Macmillan.

Kircher, Athanasius. 1636. Prodromus Coptus sive Aegyptiacus. Rome: Societas Congregatio de 
Propaganda Fide.

Kirner-Ludwig, Monika, and Iris Zimmermann. 2015. "Quoting and Plagiarising-Concepts of Both Now and Then?" In The Pragmatics of Quoting Now and Then, edited by Jenny Arendholz, Wolfram Bublitz, and Monika Kirner-Ludwig, 291-318. Topics in English Linguistics 89. Berlin: De Gruyter Mouton.

Koch, Dietrich-Alex. 1986. Die Schrift als Zeuge des Evangeliums: Untersuchungen zur Verwendung und zum Verständnis der Schrift bei Paulus. Beiträge zur historischen Theologie 69. Tübingen: Mohr Siebeck.

Kosack, Wolfgang. 2013. Shenoute of Atripe "De vita christiana": M 604 Pierpont-Morgan-Library New York/Ms. OR 12689 British-Library/London and Ms. Clarendon Press b. 4, Frg. Bodleian-Library/Oxford. Basel: Verlag Christoph Brunner.

Kraatz, Wilhelm. 1904. Koptische Akten zum ephesinischen Konzil vom Jahre 431. Leipzig: J.C. Hinrichs.

Kraft, Robert A. 1976. “An Unpublished Coptic Sahidic Psalter Codex at the University Museum in Philadelphia: A Preliminary Report.” In Armenian and Biblical Studies, edited by Michael E. Stone, 81-89. Jerusalem: St. James Press.

Krause, Thomas, and Amir Zeldes. 2016. “ANNIS3: A New Architecture for Generic Corpus Query and Visualization." Digital Scholarship in the Humanities 31 (1): 118-39.

Krawiec, Rebecca. 2002. Shenoute and the Women of the White Monastery: Egyptian Monasticism in Late Antiquity. Oxford: Oxford University Press.

— 2013. "Shenoute." The Encyclopedia of Ancient History, edited by Roger S. Bagnall. Wiley 
Online Library ed. Malden, Massachusetts: Wiley-Blackwell. Accessed September 12, 2021, https://onlinelibrary.wiley.com/doi/10.1002/9781444338386.wbeah12191.pub2.

DOI:

10.1002/9781444338386.wbeah12191.pub2.

Kristeva, Julia. 1969. Sèméiôtikè - Recherches pour une Sémanalyse. coll.«Points Essais. Paris: Seuil.

Kuhn, Karl H. 1956a. Letters and Sermons of Besa. Corpus Scriptorum Christianorum Orientalium, 157,

Scriptores Coptici 21. Louvain: Imprimerie Orientaliste L.Durbecq.

1956b. Letters and Sermons of Besa. Corpus Scriptorum Christianorum Orientalium, 158,

Scriptores Coptici 22. Louvain: Imprimerie Orientaliste L.Durbecq.

- 1960a. Pseudo-Shenoute, On Christian Behaviour. Corpus Scriptorum Christianorum

Orientalium, 206, Scriptores Coptici 29. Louvain: Imprimerie Orientaliste L.Durbecq.

. 1960b. Pseudo-Shenoute, On Christian Behaviour. Corpus Scriptorum Christianorum

Orientalium, 207, Scriptores Coptici 30. Louvain: Imprimerie Orientaliste L.Durbecq.

Kynes, Will. 2012. My Psalm Has Turned into Weeping: Job's Dialogue with the Psalms. Beihefte zur

Zeitschrift für die alttestamentliche Wissenschaft 437. Berlin: De Gruyter.

Lakoff, George, and Mark Johnson. 1980. Metaphors We Live By. Chicago, IL: University of Chicago Press.

Lange, Armin, and Matthias Weigold. 2011. Biblical Quotations and Allusions in Second Temple Jewish Literature. Göttingen: Vandenhoeck \& Ruprecht.

van Lantschoot, Arnold. 1929. Recueil des Colophons des Manuscrits Chrétiens d'Égypte. Bibliothèque du Muséon, vol. 1. Louvain: J.B. Istas, imprimeur.

Larsen, Lillian I., and Samuel Rubenson, eds. 2018. Monastic Education in Late Antiquity: The 
Transformation of Classical Paideia. Cambridge: Cambridge University Press.

Layton, Bentley. 1987. Catalogue of Coptic Literary Manuscripts in the British Library Acquired since the Year 1906. London: The British Library.

2002. "Social Structure and Food Consumption in an Early Christian Monastery: The Evidence of Shenoute's Canons and the White Monastery Federation A.D. 385-465." Le Muséon 115: $25-55$.

_ 2007. "Rules, Patterns, and the Exercise of Power in Shenoute's Monastery: The Problem of World Replacement and Identity Maintenance.” Journal of Early Christian Studies 15 (1): 4573.

. 2009. “The Monastic Rules of Shenoute.” In Monastic Estates in Late Antique and Early Islamic Egypt: Ostraca, Papyri, and Essays in Memory of Sarah Clackson, edited by Anne Boud'hors, James Clackson, Catherine Louis, and Petra Sijpesteijn, 73-81. American Studies in Papyrology 46. Cincinnati, OH: The American Society of Papyrologists.

. 2011. A Coptic Grammar: With Chrestomathy and Glossary: Sahidic Dialect. 3rd ed. Porta Linguarum Orientalium Neue Serie 20. Wiesbaden: Harrassowitz Verlag. . 2014. The Canons of Our Fathers: Monastic Rules of Shenoute. Oxford: Oxford University Press.

Lee, Suk Yee. 2016. An Intertextual Analysis of Zechariah 9-10. London: Bloomsbury T\&T Clark; Reprint edition.

Lefort, Louis Théophile. 1939. “Fragments d'Apocryphes en Copte-Akhmîmique.” Le Muséon 52: 110. 
_ 1955a. S. Athanase. Lettres Festales et Pastorales en Copte. Corpus Scriptorum Christianorum

Orientalium 150, Scriptores Coptici 19. Louvain: L. Durbecq.

- 1955b. S. Athanase. Lettres Festales et Pastorales en Copte. Corpus Scriptorum Christianorum

Orientalium 151, Scriptores Coptici 20. Louvain: L. Durbecq.

1956a. Euvres de s. Pachôme et de Ses Disciples. Corpus Scriptorum Christianorum

Orientalium 159, Scriptores Coptici 23. Louvain: L. Durbecq.

—. 1956b. Euvres de s. Pachôme et de Ses Disciples. Corpus Scriptorum Christianorum

Orientalium 160, Scriptores Coptici 24. Louvain: L. Durbecq.

Leipoldt, Johannes. 1903. Schenute von Atripe und die Entstehung des national ägyptischen

Christentums. Texte und Untersuchungen zur Geschichte der altchristlichen Literatur 25(1).

Leipzig: J.C. Hinrichs.

Leipoldt, Johannes, and Walter E. Crum. 1906. Sinuthii Archimandritae Vita et Opera Omnia: I.

Sinuthii Vita Bohairice. Corpus Scriptorum Christianorum Orientalium 41, Scriptores Coptici, Series Secunda 2. Paris: E Typographeo Reipublica.

1908. Sinuthii Archimandritae Vita et Opera Omnia III. Corpus Scriptorum Christianorum

Orientalium 42, Scriptores Coptici Series Secunda 4. Paris: E Typographeo Reipublicae.

- 1913. Sinuthii Archimandritae Vita et Opera Omnia IV. Corpus Scriptorum Christianorum

Orientalium 73, Scriptores Coptici Series Secunda 5. Paris: E Typographeo Reipublicae.

von Lemm, Oscar. 1908. "Koptische Miscellen XXVI: Zur Leidener Handschrift Insinger No. 89.”

Bulletin de l'Académie Impériale des Sciences de St.-Pétersbourg, Classe des Sciences Sociales,

6th series 2: 55-60. 
Lewis, Charlton T., and Charles Short. 1956. A Latin Dictionary. Revised ed. Oxford: Clarendon Press.

Liddell, Henry George, Robert Scott, Henry Stuart Jones, and Roderick McKenzie. 1996. A GreekEnglish Lexicon: With a Revised Supplement. Revised, subsequent ed. Oxford: Clarendon Press. Lieu, Samuel N.C. 1999. Manichaeism in Mesopotamia and the Roman East. Religions in the GraecoRoman World 118. Leiden and Boston, Massachusetts: Brill.

Lincke, Eliese-Sophia, Kirill Bulert, and Marco Büchler. 2019. “Optical Character Recognition for Coptic Fonts: A Multi-Source Approach for Scholarly Editions." In Proceedings of the 3rd International Conference on Digital Access to Textual Cultural Heritage, 87-91.

Lincke, Eliese-Sophia. 2020. "Coptic OCR: Even Better Models and Improvements on UserFriendliness." Online Workshop Digital Coptic 3, accessed December 5, 2021, http://kellia.unigoettingen.de/digitalcoptic3/slides/CopticOCR_2020-12-07_Lincke.pdf.

López, Ariel G. 2013. Shenoute of Atripe and the Uses of Poverty: Rural Patronage, Religious Conflict, and Monasticism in Late Antique Egypt. Berkeley, Los Angeles, California, and London: The University of California Press.

Louis, Catherine. 2008. "The Fate of the White Monastery Library." In Christianity and Monasticism in Upper Egypt: Volume 1, Akhmim and Sohag, edited by Gawdat Gabra and Hany N. Takla, 83-90. Cairo: The American University in Cairo Press.

Lubomierski, Nina. 2007a. Die Vita Sinuthii: Form- und Überlieferungsgeschichte der hagiographischen Texte über Schenute den Archimandriten. Studien und Texte zu Antike und Christentum 45. Tübingen: Mohr Siebeck. 2007b. "Towards a Better Understanding of the So-Called "Vita Sinuthii." In Actes Du 
Huitième Congrès International d'Études Coptes, edited by Anne Boud'hors and Nathalie Bosson, 2:527-35. Orientalia Lovaniensia Analecta 163. Leuven: Peeters.

—. 2008. "The Coptic Life of Shenoute.” In Christianity and Monasticism in Upper Egypt, edited by Gawdat Gabra and Hany N. Takla, 91-98. Cairo: The American University in Cairo Press. Lundhaug, Hugo. 2008. “Cognitive Poetics and Ancient Texts.” In Complexity, edited by Willy Østreng, 18-21. Interdisciplinary Communications 2006/2007. Oslo: Centre for Advanced Study. - 2010a. Images of Rebirth: Cognitive Poetics and Transformational Soteriology in the Gospel of Philip and the Exegesis on the Soul. Leiden: Brill.

2010b. "Canon and Interpretation: A Cognitive Perspective." In Canon and Canonicity: The Formation and Use of Scripture, edited by Einar Thomassen, 67-90. Copenhagen: Museum Tusculanum Press.

. 2012a. "Mystery and Authority in the Writings of Shenoute." In Mystery and Secrecy in the Nag Hammadi Collection and Other Ancient Literature: Ideas and Practices: Studies for Einar Thomassen at Sixty, edited by Christian H. Bull, Liv Ingeborg Lied, and John D. Turner. 25986. Leiden and Boston: Brill.

- 2012b. "Shenoute's Heresiological Polemics and Its Context(s)." In Invention, Rewriting, Usurpation: Discursive Fights over Religious Traditions in Antiquity, edited by David Brakke, Jörg Ulrich, and Anders-Christian Jacobsen, 239-61. Early Christianity in the Context of Antiquity 11. Frankfurt: Peter Lang.

2013. "Origenism in Fifth-Century Upper Egypt: Shenoute of Atripe and the Nag Hammadi Codices." In Papers Presented at the Sixteenth International Conference on Patristic Studies 
held in Oxford 2011: Vol. 12: Ascetica; Litrugica; Orientalia; Critica et Philologica, edited by Markus Vinzent, 217-28. Studia Patristica 64. Leuven: Peeters.

—. 2014. "Memory and Early Monastic Literary Practices: A Cognitive Perspective." Journal of Cognitive Historiography 1 (1): 98-120. DOI: 10.1558/jch.v1i1.98.

— 2017. “'Tell Me What Shall Arise': Conflicting Notions of the Resurrection Body in Fourthand Fifth-Century Egypt." In Coming Back to Life: The Permeability of Past and Present, Mortality and Immortality, Death and Life in the Ancient Mediterranean, edited by Frederick S. Tappenden and Carly Daniel-Hughes, with the assistance of Bradley N. Rice, 215-36. Montreal, QC: McGill University Library.

Maravela, Anastasia. 2018. "Homer and Menandri Sententiae in Upper Egyptian Monastic Settings.” In Monastic Education in Late Antiquity, edited by Lillian I. Larsen and Samuel Rubenson, 12549, Cambridge: Cambridge University Press.

de Marneffe, Marie-Catherine, Bill MacCartney, Christopher D. Manning, and others. 2006. “Generating Typed Dependency Parses from Phrase Structure Parses.” In LREC 2006 Proceedings: $5^{\text {th }}$ Edition of the International Conference on Language Resources and Evaluation, edited by Nicoletta Calzolari, Khalid Choukri, Aldo Gangemi, Bente Maegaard, Joseph Mariani, Jan Odijk, and Daniel Tapias. 449-54. Genoa: European Language Resources $\begin{array}{llll}\text { Association. } & \text { Accessed } & \text { November } & \text { 11, }\end{array}$ https://nlp.stanford.edu/pubs/LREC06_dependencies.pdf.

de Marneffe, Marie-Catherine, and Christopher D. Manning. 2008a. "Stanford Typed Dependencies Manual." Technical report, Stanford University. Accessed November 11, 2021, 
https://nlp.stanford.edu/software/dependencies_manual.pdf.

2008b. "The Stanford Typed Dependencies Representation." In Coling 2008: 22nd

International Conference on Computational Linguistics: Proceedings of the Workshop on

Cross-Framework and Cross-Domain Parser Evaluation, edited by Johan Bos, Edward Briscoe,

Aoife Cahill, John Carroll, Stephen Clark, Ann Copestake, Dan Flickinger, Josef van Genabith,

Julia Hockenmaier, Aravind Joshi, Ronald Kaplan, Tracy Holloway King, Sandra Kübler,

Dekang Lin, Jan Tore Lønning, Christopher Manning, Yusuke Miyao, Joakim Nivre, Stephan

Oepen, Kenji Sagae, Nianwen Xue, and Yi Zhang. 1-8. Manchester, the United Kingdom:

Association for Computational Linguistics. DOI: 10.5555/1608858.1608859.

de Marneffe, Marie-Catherine, Timothy Dozat, Natalia Silveira, Katri Haverinen, Filip Ginter, Joakim

Nivre, and Christopher D. Manning. 2014. "Universal Stanford Dependencies: A Cross-

Linguistic Typology.” In LREC 2014 Proceedings: The Ninth International Conference on

Language Resources and Evaluation, edited by Nicoletta Calzolari, Khalid Choukri, Thierry

Declerck, Hrafn Loftsson, Bente Maegaard, Joseph Mariani, Asuncion Moreno, Jan Odijk,

Stelios Piperidis, Hélène Mazo, and Sara Goggi. 4585-92. Reykjavik: European Language

Resources Association. Accessed November 11, 2021,

https://nlp.stanford.edu/pubs/USD_LREC14_paper_camera_ready.pdf.

Masoner, Anna. 2018. “Ein Jesuitenpater als Computerpionier.” Science ORF.at. Accessed September

12, 2021, https://science.orf.at/stories/2904212/.

1886. "Fragments Coptes." Recueil de Travaux Relatifs à la Philologie et à l'Archéologie

Égyptiennes et Assyriennes 7: 46-48, 142-44. Accessed November 11, 2021, 
https://digi.ub.uni-heidelberg.de/diglit/rectrav1886.

Maspero, Gaston. 1892. Fragments de la Version Thébaine de l'Ancien Testament - Fragments de Manuscrits Copte-Thébains Provenant de la Bibliothèque du Deir Amba-Shenoudah. Mémoires Publiés par les Membres de la Mission Archéologique Française au Caire 6. Paris: E. Leroux.

McMurtrie, Douglas C. 1921. The Origin \& Development of the Marks of Quotation. London: privately printed. Accessed November 11 , 2021, https://babel.hathitrust.org/cgi/pt?id=mdp.39015033596159\&view=1up\&seq=1.

McMurtrie, Douglas C. 1934. Concerning Quotation Marks. New York: privately printed. Accessed November $\quad$ 2021, $\quad$ https://media.aphelis.net/wpcontent/uploads/2012/12/McMURTRIE_1933_Quotation_Mark_light.pdf.

Mellerin, Laurence. 2013. "Background: From Biblia Patristica to BiblIndex.” BIBLINDEX: research notebook. Accessed September 12, 2021, http://biblindex-en.hypotheses.org/22.

Mellerin, Laurence, and Hugh A. G. Houghton, eds. 2013. Biblical Quotations in Patristic Texts. Studia Patristica 54. Leuven: Peeters.

Meyer, Robert T. 1950. St. Athanasius: The Life of Saint Antony. Ancient Christian Writers: The Works of the Fathers in Translation 10. New York NY and Mahwah NJ: Newman Press.

Miyagawa, So. 2017. "The ang- Morphs in Coptic and their Grammaticalization in Later Egyptian.” In Proceedings of the XI International Congress of Egyptologists, Florence, Italy 23-30 August 2015, edited by M. Cristina Guidotti and Gloria Rosati. 416-21. Oxford: Archaeopress.

Miyagawa, So and Heike Behlmer. Forthcoming a. "Quotative Index Phrases in Shenoute's Canon 6: A 
Case Study of Quotations from the Psalms.” In: Uses and Misuses of Ancient Mediterranean Sources: Erudition, Authority, Manipulation, edited by Chiara Meccariello and Jennifer Singletary. 101-16. Studies in Education and Religion in Ancient and Pre-Modern History in the Mediterranean and Its Environs 15. Tübingen: Mohr Siebeck.

Miyagawa, So and Heike Behlmer. Forthcoming b. "Linguistic Analysis on Introducing Quotations in Selected Coptic Monastic Writings: Shenoute, Canon 6 and Besa." In Crossroads VI: Proceedings of the Sixth International Congress of Egyptian Linguistics, edited by Andreas Dorn and Sami Uljas. Uppsala: Uppsala University Press.

Miyagawa, So, Marco Büchler, and Heike Behlmer. Forthcoming. "Computational Analysis of Text Reuse/Intertextuality: The Example of Shenoute Canon 6." In Proceedings of the Eleventh International Congress of Coptic Studies, edited by Hany N. Takla, Stephen Emmel, and Maged S. A. Mikhail. Orientalia Lovaniensia Analecta. Peeters: Leuven.

Miyagawa, So, Kirill Bulert, Marco Büchler, and Heike Behlmer. 2019. “Optical Character Recognition of Typeset Coptic Text with Neural Networks." Digital Scholarship in the Humanities 34 (Supplement 1): i135-41. Accessed November 11, 2021, https://academic.oup.com/dsh/articlepdf/34/Supplement_1/i135/31686028/fqz023.pdf.

Miyagawa, So, Amir Zeldes, Marco Büchler, Heike Behlmer, and Troy Griffitts. 2018. "Building Linguistically and Intertextually Tagged Coptic Corpora with Open Source Tools.” In Proceedings of the 8th Conference of Japanese Association for Digital Humanities, edited by Chikahiko Suzuki, 139-41. Tokyo: Center for Open Data in the Humanities. Accessed November 11, 2021, https://corpling.uis.georgetown.edu/amir/pdf/MiyagawaEtAl2018.pdf. 
Moawad, Samuel. 2008. "The Relationship of St. Shenoute of Atripe with His Contemporary Patriarchs of Alexandria." In Christianity and Monasticism in Upper Egypt: Volume 1: Akhmim and Sohag, 107-16. Cairo: The American University in Cairo Press.

Morlock, Emmanuelle. 2014. “TEI Encoding Patterns for Citations, Quotations and Allusions: what's 'in Stock'?.' International workshop on computer aided processing of intertextuality in ancient languages, accessed December 4, 2021, http://biblindex.hypotheses.org/files/2014/04/teicitations-whatsinstock.pdf.

Moretti, Franco. 2000. “Conjectures on World Literature.” New Left Review 1: 54-68. Accessed November 11, 2021, https://newleftreview.org/issues/ii1/articles/franco-moretti-conjectureson-world-literature.pdf.

Moussa, Mark. 1998/99. “I Am Amazed: Shenoute of Atripe's Endorsement of Alexandrian Theology in the White Monastery." Bulletin of Saint Shenouda the Archimandrite Coptic Society 5: 1940. Accessed November 11 , 2021, https://www.academia.edu/1854470/I_Am_Amazed_Shenoute_of_Atripes_Endorsement_of_ Alexandrian_Theology_in_the_White_Monastery. . 2010. I Have Been Reading the Holy Gospels by Shenoute of Atripe (Discourses 8, Work 1): Coptic Text, Translation, and Commentary. PhD thesis, Catholic University of America. $\begin{array}{lll}\text { Accessed } & \text { November } & \text { 2021, }\end{array}$ https://www.academia.edu/1854474/I_Have_Been_Reading_the_Holy_Gospels_by_Shenoute _of_Atripe_Discourses_8_Work_1_Coptic_Text_Translation_and_Commentary.

Munier, Henri. 1916. Manuscripts Coptes: CGC Nos. 9201-9304. Cairo: Imprimerie de 1'Institut 
Français d'Archéologie Orientale.

Nagel, Peter. 1960. "Editionen koptischer Bibeltexte seit Till.” Archiv für Papyrusforschung 35: 43100.

1974. "Die Septuaginta-Zitate in der koptisch-gnostischen 'Exegese über die Seele' (Nag Hammadi Codex II).” Archiv für Papyrusforschung 22: 249-69.

1983. "Studien zur Textüberlieferung des sahidischen Alten Testaments, Teil I.” Zeitschrift für Ägyptische Sprache und Altertumskunde 110: 51-74.

_ 1984a. "Griechisch-Koptische Bilinguen des Alten Testaments." In Griechen und Kopten im byzantinischen Ägypten, edited by Peter Nagel, 231-57. Wissenschaftliche Beiträge der MartinLuther-Universität Halle-Wittenberg 48. Halle (Saale): Martin-Luther-Universität.

1984b. "Studien zur Textüberlieferung des sahidischen Alten Testaments, Teil II.” Zeitschrift für Ägyptische Sprache und Altertumskunde 111: 138-64.

—. 1987. "Sahidische Pentateuchfragmente." Zeitschrift für Ägyptische Sprache und Altertumskunde 114: 134-66.

- 1988. "Textumfang und Textabfolge der sahidischen Version des Buches Exodus." In Nubia et Oriens Christianus: Festschrift für C. Detlef G. Müller zum 60. Geburtstag, edited by Piotr O. Scholz and R. Stempel, 181-89. Bibliotheca Nubica 1. Cologne: Archeobooks.

— 1989. "Fragmente eines sahidischen Genesiskodex der Nationalbibliothek zu Paris (BN copte 129.01.08-13).” Zeitschrift für Ägyptische Sprache und Altertumskunde 116: 71-90.

. 1991. “Old Testament, Coptic Translations Of.” In The Coptic Encyclopedia, edited by Aziz Suryal Atiya, 6:1836-40. New York: Macmillan. 
1994. "Aufbau und Komposition des Papyruskodex BL Or. 7594 der British Library.” In

Coptology: Past, Present, and Future: Studies in Honour of Rodolphe Kasser, edited by Søren

Giversen, Martin Krause, and Peter Nagel, 347-55. Orientalia Lovaniensia Analecta 61.

Leuven: Peeters.

1999. "Die Arbeit an den koptischen Bibeltexten 1992-1996." In Ägypten und Nubien in spätantiker und christlicher Zeit: Akten des 6. Internationalen Koptologenkongresses Münster, 20.-26. Juli, edited by Stephen Emmel, Martin Krause, Siegfried G. Richter, and Sofia Schaten, 2:38-48. Sprachen und Kulturen des christlichen Orients 6. Wiesbaden: Harrassowitz.

2000. "Der sahidische Psalter — seine Erschließung und Erforschung 90 Jahre nach Alfred

Rahlfs' Studien zum Text des Septuaginta-Psalters.” In Der Septuaginta-Psalter und seine Tochterübersetzungen: Symposium in Göttingen, edited by Anneli Aejmelaeus and Udo Quast, 82-96. Abhandlungen der Akademie der Wissenschaften in Göttingen, PhilologischHistorische Klasse Folge 3 230, Mitteilungen des Septuaginta-Unternehmens 24. Göttingen: Vandenhoeck \& Ruprecht.

2002. "Koptische Bibelhandschriften des Alten Testaments aus frühislamischer Zeit.” In Die Koptische Kirche in den ersten drei islamischen Jahrhunderten: Beiträge zum gleichnamigen Leucorea-Kolloquium, edited by Walter Beltz, 131-55. Hallesche Beiträge zur Orientwissenschaft 36. Halle (Saale): Martin-Luther-Universität.

—. 2016. "Coptic Translations." In Textual History of the Bible : The Hebrew Bible : Volume 1C : Writings, edited by Armin Lange and Emanuel Tov, 119-22. Leiden: Brill.

Nasim, Sulayman. 1991. "Education, Coptic.” In The Coptic Encyclopedia, edited by Aziz Suryal Atiya, 
3: 931-33. New York: Macmillan.

Nestle, Eberhard, Erwin Nestle, Barbara Aland, Kurt Aland, Iōan D. Karavidopoulos, Carlo Maria Martini, Bruce M. Metzger, and Holger Strutwolf. 2012. Novum Testamentum. 28th ed. Stuttgart: Deutsche Bibelgesellschaft.

New, David S. 1993. Old Testament Quotations in the Synoptic Gospels, and the Two-Document Hypothesis. Society of Biblical Literature Septuagint and Cognate Studies Series 37. Atlanta, GA: Scholars Press.

Nouwen, Henri J. M., and Yushi Nomura. 2001. Desert Wisdom: Sayings from the Desert Fathers. Ossining, New York: Orbis Books.

Orlandi, Tito. 1985. Shenute contra Origenistas: Testo con Introduzione e Traduzione. Rome: C.I.M. 1990. "The Corpus dei Manoscritti Copti Letterari." Computers and the Humanities 24: 397405.

_ 2002. "The Library of the Monastery of Saint Shenute at Atripe." In Perspectives on Panopolis: An Egyptian Town from Alexander the Great to the Arab Conquest: Acts from an International Symposium Held in Leiden on 16, 17 and 18 December, edited by Arne Egberts, Brian Paul Muhs, and Jacques van der Vliet, 211-32. Papyrologica Lugduno-Batava 31. Leiden: Brill.

Okajima, Seitarō. 1942. Koptogo Shōbunten [Concise Grammar of Coptic Language]. Nara: Asukaen. Osburn, Carroll D. 2005. "Methodology in Identifying Patristic Citations in NT Textual Criticism." Novum Testamentum 47 (4): 313-43.

Parkes, Malcolm B. 1992. Pause and Effect: An Introduction to the History of Punctuation in the West. London: Routledge. 
Pautler, André, and Jean Allenbach. 2000. Biblia Patristica: Index des Citations et Allusions Bibliques dans la Littérature Patristique: 7: Didyme d'Alexandrie. Vol. 7. Paris: Édition du Centre National de la Recherche Scientifique.

Pedersen, Nils Arne. 2009. "The New Testament Canon and Athanasius of Alexandria's 39th Festal Letter." In The Discursive Fight over Religious Texts in Antiquity, edited by Anders-Christian Jacobsen, 168-77. Religion and Normativity 1. Aarhus: Aarhus University Press.

Pedersen, Nils Arne, René Falkenberg, John Møller Larsen, and Claudia Leurini. 2017. The Old Testament in Manichaean Tradition: The Sources in Syriac, Greek, Coptic, middle Perisan, Parthian, Sogdian, new Persian, and Arabic: with an Appendix on General References to the Bible. Corpus Fontium Manichaeorum: Biblia Manichaica 2. Turnhout: Brepols.

2020. The New Testament in Manichaean Tradition: The Sources in Syriac, Greek, Coptic, Middle Perisan, Parthian, Sogdian, Bactrian, New Persian, and Arabic. Corpus Fontium Manichaeorum: Biblia Manichaica 1. Turnhout: Brepols.

Petrov, Slav, Dipanjan Das, and Ryan McDonald. 2012. "A Universal Part-of-Speech Tagset." In Proceedings of Eighth International Conference on Language Resources and Evaluation (LREC'12), edited by Nicoletta Calzolari, Khalid Choukri, Thierry Declerck, Mehmet Uğur Doğan, Bente Maegaard, Joseph Mariani, Asuncion Moreno, Jan Odijk, and Stelios Piperidis, 2089-96. Istanbul: European Language Resources Association.

Pietersma, Albert, and Benjamin G. Wright, eds. 2007. A New English Translation of the Septuagint: And the Other Greek Translations Traditionally Included under that Title. Oxford: Oxford University Press. 
Pleyte, Willem, and Pieter Adriaan Aart Boeser. 1897. Manuscrits coptes du musée d'Antiquités des Pays-Bas à Leide. Leiden: Librairie et Imprimerie Ci-Devant E.T. Brill.

Pollard, Carl, and Ivan A. Sag. 1994. Head-Driven Phrase Structure Grammar. Chicago: The University of Chicago Press.

Porter, Stanley E. and Christopher D. Land (eds.) 2019. Paul and Scripture. Pauline Studies 10. Leiden: Brill.

Potthast, Martin. 2012. Technologies for Reusing Text from the Web. PhD thesis, Bauhaus University Weimar.

Prince, J. Dyneley. 1902. “Two Versions of the Coptic Psalter.” Journal of Biblical Literature 21 (1): 92-99.

Price, Richard and Thomas Graumann. 2020. The Council of Ephesus of 431: Documents and Proceedings. Translated Texts for Historians 72. Liverpool: Liverpool University Press.

Quecke, Hans. 1970. Untersuchungen zum koptischen Stundengebet. Publications de l'Institut Orientaliste de Louvain 3. Louvain: Université Catholique, Institut Orientaliste.

1995 “Psalmverse als „Hymnen“ in der kopitschen Liturgie? In Christianisme d’Égypte: Hommages à René-Georges Coquin, edited by le groupe de recherche Bibliothèque Copte, Centre de recherches d'histoire des religions de l'Université des sciences humaines de Strasbourg, 101-14. Cahiers de la Bibliothèque copte 9. Paris and Louvain: Peeters.

Rahlfs, Alfred. 1904. Die Berliner Handschrift des sahidischen Psalters. Abhandlungen der Königlichen Gesellschaft der Wissenschaften zu Göttingen. Phil.-hist. Klasse, N. F. Bd. 4. Berlin: Weidmannsche Buchhandlung. 
—. 1931. Septuaginta: Vetus Testamentum Graecum. 10, Psalmi cum Odis. Göttingen: Vandenhoeck \& Ruprecht.

Rahlfs, Alfred and Detlef Fraenkel. 2004. Verzeichnis der griechischen Handschriften des Alten Testaments: Bd. I,1: Die Überlieferung bis zum VIII. Jahrhundert (Septuaginta: Vetus Testamentum Graecum, Supplementum). Göttingen: Vandenhoeck \& Ruprecht.

Rahlfs, Alfred, and Robert Hanhart, eds. 2014. Septuaginta: Das Alte Testament Griechisch: Editio altera. 4th ed. Stuttgart: Deutsche Bibelgesellschaft.

Reed, Annette Y. 2015. "The Afterlives of New Testament Apocrypha." Journal of Biblical Literature 134 (2): 401-25.

Reul, Christian, Uwe Springmann, Christoph Wick, and Frank Puppe. 2018. "Improving OCR Accuracy on Early Printed Books by Combining Pretraining, Voting, and Active Learning.” The Journal for Language Technology and Computational Linguistics 33 (1): 3-24.

Ricardou, Jean. 1971. Pour une Théorie du Nouveau Roman. Paris: Seuil.

Richter, Siegfried G. 2008. "Manichaeism and Gnosticism in the Panopolitan Region between Lykopolis and Nag Hammadi." In Christianity and Monasticism in Upper Egypt: Volume 1: Akhmim and Sohag, edited by Gawdat Gabra and Hany N. Takla. 121-29. Cairo: The American University of Cairo Press.

Roberts, Alexander, and James Donaldson. 1885. Ante-Nicene Fathers, Vol. 2: Translations of the Writings of the Fathers down to A.D. 325. New York: The Christian Literature Company.

Rönnegård, Per. 2010. Threads and Images: The Use of Scripture in Apophthegmata Patrum. Winona Lake, IN: Eisenbrauns. 
Rubenson, Samuel. 1995. The Letters of St. Antony: Monasticism and the Making of a Saint. London: A\&C Black.

Rudd, Niall. 2005. The Satires of Horace and Persius. Reprint, translation edition. Penguin Classics. London: Penguin Books.

Sanzo, Joseph E. 2014. Scriptural Incipits on Amulets from Late Antique Egypt. Text, Typology, and Theory. Studien und Texte zu Antike und Christentum 84. Tübingen: Mohr Siebeck.

Scaliger, Josephus Justus. 1598. Opus de Emendatione Temporum: Castigatius \& Multus Partibus Auctius, vt Nouum Videri Possit: Item Vetervm Grcecorvm Fragmenta Selecta. Lugduni Batavorum. Paris: Ex Officina Plantiniana Francisci Raphelengij.

Schmid, Helmut. 1994. "Probabilistic Part-of-Speech Tagging Using Decision Trees.” In Proceedings of International Conference on New Methods in Language Processing, edited by Daniel Jones. 44-9. Manchester: Centre for Computational Linguistics.

Schmid, Ulrich. 1995. Marcion und sein Apostolos: Rekonstruktion und historische Einordnung der Marcionitischen Paulusbriefausgabe. Berlin: Walter de Gruyter.

2010. “Transmitting the New Testament Online.” In Text Comparison and Digital Creativity, edited by Ernst Thoutenhoofd, Wido Th. Peursen, and Adriaan Weel, 189-206. Leiden: Brill. Schnittjer, Gary E. 2021. Old Testament Use of Old Testament: A Book-by-Book Guide. Grand Rapids, MI: Zondervan.

Schroeder, Caroline T. 2006. "Prophecy and Porneia in Shenoute's Letters: The Rhetoric of Sexuality in a Late Antique Egyptian Monastery.” Journal of Near Eastern Studies 65 (2): 81-97. DOI: 10.1558/jch.v1i1.98. 
2013. Monastic Bodies: Discipline and Salvation in Shenoute of Atripe. Philadelphia,

Pennsylvania: University of Pennsylvania Press.

2015. "Shenoute in Code: Digitizing Coptic Cultural Heritage for Collaborative Online

Research and Study.” Coptica 14: 21-36.

Schroeder, Caroline T., and Amir Zeldes. 2018. "Raiders of the Lost Corpus." Digital Humanities $\begin{array}{llllll}\text { Quarterly } & 10 & \text { (2). } & \text { Accessed } & \text { September } & \text { 12, }\end{array}$ http://www.digitalhumanities.org/dhq/vol/10/2/000247/000247.html.

Schüssler, Karlheinz. 1995. Das sahidische Alte und Neue Testament: sa 1-20. Biblia Coptica, Bd.1, Lfg. 1. Wiesbaden: Harrassowitz Verlag.

1996. Das sahidische Alte und Neue Testament: sa 21-48. Biblia Coptica, Bd. 1, Lfg. 2. Wiesbaden: Harrassowitz Verlag.

1998. Das sahidische Alte und Neue Testament: sa 49-9. Biblia Coptica, Bd. 1, Lfg. 3, 2.

Wiesbaden: Harrassowitz Verlag.

2000. Das sahidische Alte und Neue Testament: vollständiges Verzeichnis mit Standorten, sa

93-120. Biblia Coptica, Bd. 1, Lfg. 4. Wiesbaden: Harrassowitz Verlag.

. 2001. Das sahidische Alte und Neue Testament: vollständiges Verzeichnis mit Standorten; sa

500-520. Biblia Coptica, Bd. 3, Lfg. 1. Wiesbaden: Harrassowitz Verlag.

. 2003. Das sahidische Alte und Neue Testament: vollständiges Verzeichnis mit Standorten; sa

521-540. Biblia Coptica, Bd. 3, Lfg. 2. Wiesbaden: Harrassowitz Verlag.

2004. Das sahidische Alte und Neue Testament: vollständiges Verzeichnis mit Standorten; sa

541-560. Biblia Coptica, Bd. 3, Lfg. 3. Wiesbaden: Harrassowitz Verlag. 
2006. Das sahidische Alte und Neue Testament: vollständiges Verzeichnis mit Standorten, sa 561-585. Biblia Coptica, Bd. 3, Lfg. 4. Wiesbaden: Harrassowitz Verlag. 2007. Das sahidische Alte und Neue Testament: vollständiges Verzeichnis mit Standorten; sa 586-620. Biblia Coptica, Bd. 4, Lfg. 1. Wiesbaden: Harrassowitz Verlag.

2009. Das sahidische Alte und Neue Testament: vollständiges Verzeichnis mit Standorten, sa 621-672. Biblia Coptica, Bd. 4, Lfg. 2. Wiesbaden: Harrassowitz Verlag.

-2010. Das sahidische Alte und Neue Testament: vollständiges Verzeichnis mit Standorten, sa 673-720. Biblia Coptica, Bd. 4, Lfg. 3. Wiesbaden: Harrassowitz Verlag.

2011. Das sahidische Alte und Neue Testament: vollständiges Verzeichnis mit Standorten, sa 721-780. Biblia Coptica / Bd. 4, Lfg. 4. Wiesbaden: Harrassowitz Verlag. . 2012. Das sahidische Alte und Neue Testament: vollständiges Verzeichnis mit Standorten, sa 121-184. Biblia Coptica, Bd. 2, Lfg. 1. Wiesbaden: Harrassowitz Verlag. 2015. Das sahidische Alte und Neue Testament: vollständiges Verzeichnis mit Standorten, sa 185-260. Biblia Coptica, Bd. 2, Lfg. 2. Bearbeitet von Frank Feder und Hans Förster. Wiesbaden: Harrassowitz Verlag.

Shenouda III, Pope. 2016. The Life of Repentance and Purity. Translated by Bishop Suriel of Melbourne. 2nd ed. Yonkers, New York: St Vladimir's Seminary Press.

Shi, Yong, Lingling Zhang, Yingjie Tian, and Xingsen Li. 2015. Intelligent Knowledge: A Study beyond Data Mining. Basel: Springer.

Shisha-Halevy, Ariel. 1975. "Two New Shenoute-Texts from the British Library.” Orientalia 44 (2): $149-85$. 
1976. "Unpublished Shenoutiana: Grammatical-Phraseological Commentary.” Enchoria 6: 29-

62.

1986. Coptic Grammatical Categories: Structural Studies in the Syntax of Shenoutean Sahidic.

Analecta Orientalia 53. Rome: Pontificium Institutum Biblicum.

1992. "The Shenutean Idiom.” In The Coptic Encyclopaedia, edited by Aziz Suryal Atiya,

8:202-04. New York: Macmillan.

2016a. "Nominal Predications in Shenoute's Rhetorical Poetics." In Coptic Society, Literature

and Religion from Late Antiquity to Modern Times: Proceedings of the Tenth International

Congress of Coptic Studies, Rome, September 17th-22 Th, 2012 and Plenary Reports of the

Ninth International Congress of Coptic Studies, Cairo, September 15th-19th, 2008, edited by

Paola Buzi, Alberto Camplani, and Federico Contardi. 1333-38. Orientalia Lovaniensia

Analecta 247. Leuven, Paris and Bristol, Connecticut: Peeters.

. 2016b. "Diversions of Juncture on Shenoutean Anacoluthia, and Other Puzzles of Unexpected

Syntax." Journal of Coptic Studies 18: 113-79.

Slaughter, Laura, Luis Morgado da Costa, So Miyagawa, Marco Büchler, Amir Zeldes, Hugo Lundhaug, and Heike Behlmer. 2019. "The Making of Coptic Wordnet." In Proceedings of the Tenth Global Wordnet Conference, edited by Christiane Fellbaum, Piek Vossen, Ewa Rudnicka, Marek Maziarz, and Maciej Piasecki. 166-75. Wrocław: Oficyna Wydawnicza Politechniki Wrocławskiej.

Smith, David A., Jeffrey A. Rydberg-Cox, and Gregory R. Crane. 2000. “The Perseus Project: A Digital Library for the Humanities." Literary and Linguistic Computing 1: 15-25. 
Springmann, Uwe, Dietmar Najock, Hermann Morgenroth, Helmut Schmid, Annette Gotscharek, and Florian Fink. 2014. "OCR of Historical Printings of Latin Texts: Problems, Prospects, Progress.” In DATeCH'14: Proceedings of the First International Conference on Digital Access to Textual Cultural Heritage, edited by Apostolos Antonacopoulos and Klaus U. Schulz. 71-5. New York: Association for Computing Machinery.

Srivastava, Ashok, and Mehran Sahami, eds. 2009. Text Mining: Classification, Clustering, and Applications. Boca Raton, Florida: Chapman \& Hall/CRC.

Stead, Michael R. 2009. The Intertextuality of Zechariah 1-8. London: Bloomsbury T \& T Clark .

Suciu, Alin and Tito Orlandi. 2016. "The End of the Library of the Monastery of Atripe." In Coptic Society, Literature and Religion from Late Antiquity to Modern Times: Proceedings of the Tenth International Congress of Coptic Studies, Rome, September 17th-22 Th, 2012 and Plenary Reports of the Ninth International Congress of Coptic Studies, Cairo, September 15th19th, 2008, edited by Paola Buzi, Alberto Camplani, and Federico Contardi. 87-90. Orientalia Lovaniensia Analecta 247. Leuven, Paris and Bristol, Connecticut: Peeters.

Sundberg, Jr., Albert C. 1973. "Canon Muratori: A Fourth Century List.” Harvard Theological Review 66: $1-41$.

Takla, Hany N. 1996. "The Sahidic Book of Tobit.” Bulletin of the Saint Shenouda the Archimandrite Coptic Society 3: 1-25.

2005. "Borgia Z32: An Old Testament Lectionary from the Monastery of St. Shenouda." Saint Shenouda Coptic Quarterly 1 (No. 4): 3-18.

—. 2007. “An Introduction to the Coptic Old Testament." Coptica 6: iii-115. 
. 2008. "Biblical Manuscripts of the Monastery of St. Shenoute the Archimandrite." In Christianity and Monasticism in Upper Egypt: I. Akhmim and Sohag, edited by Gawdat Gabra and Hany N. Takla, 155-67. Cairo: The American University in Cairo Press.

. 2010. "The Surviving Remains of the Book of Jeremiah from Saint Shenouda's Monastery." Coptica 9: 83-89.

. 2014. "Coptic Language: The Link to Ancient Egyptian". In The Coptic Christian Heritage: History, Faith, Culture, edited by Lois M. Farag, 179-94. London/New York: Routledge.

Tiepmar, Jochen, and Gerhard Heyer. 2017. “An Overview of Canonical Text Services.” Linguistics and Literature Studies 5 (2): 132-48.

Till, Walter. 1942. “Zur Worttrennung im Koptischen.” Zeitschrift für Ägyptische Sprache und Altertumskunde 77 (1): 48-52.

Timbie, Janet A. 2007. "Non-Canonical Scriptural Citation in Shenoute.” In Actes Du Huitième Congrès International d'études Coptes: Paris, 28 Juin-3 Juillet, edited by Nathalie Bosson and Anne Boud'hors, 625-34. Leuven: Peeters.

2011. "The Interpretation of the Solomonic Books in Coptic Monastic Texts: 'Reading' Community." In Christianity in Egypt: Literary Production and Intellectual Trends: Studies in Honor of Tito Orlandi, edited by Paola Buzi and Alberto Camplani. 501-12. Studia Ephemeridis “Augustinianum” 125. Rome: Institutum Patristicum Augustinianum.

2013. "Writing Rules and Quoting Scripture in Early Coptic Monastic Texts." In Ascetic Culture: Essays in Honor of Philip Rousseau, edited by Blake Leyerle and Robin Darling Young. 29-48. Notre Dame, Indiana: The University of Notre Dame Press. 
2015. "Shenoute of Atripe.” In Wiley Blackwell Companion to Patristics, edited by Ken Parry, 184-96. Oxford: Wiley Blackwell.

2016. "Education of Shenoute." Education and Religion in Late Antiquity: Reflections, Social Contexts and Genres, edited by Peter Gemeinhardt, Lieve van Hoof, and Peter van Nuffelen. 34-46. London: Routledge.

Timbie, Janet A., and Jason R. Zaborowski. 2006. "Shenoute's Sermon The Lord Thundered: An Introduction and Translation." Oriens Christianus 90: 91-123.

Tsutsui, Kenji. 2004. Gnōsis: Kodai Kirisuto-Kyō No "Itan Shisō" [Gnosis: Heretic Thoughts in Ancient Christianity]. Tokyo: Kōdansha.

Tuki, Raphael. 1778. Rudimenta Linguae Coptae sive Aegyptiacae. Rome: Typis Sacrae Congregationis. Unicode Staff, CORPORATE. 1991. "The Unicode Standard: Worldwide Character Encoding." Addison-Wesley Longman Publishing Co., Inc.

Veilleux, Armand. 1980. Pachomian Koinonia, Vol. 1, the Life of Saint Pachomius and His Disciples. Kalamazoo, Michigan: Cistercian Publications. 1981. Pachomian Koinonia, Vol. 2, Pachomian Chronicles and Rules. Kalamazoo, Michigan: Cistercian Publications.

Ward, Benedicta. 2003. The Desert Fathers: Sayings of the Early Christian Monks. London: Penguin Books.

Wessely, Carl. 1909. Griechische und koptische Texte theologischen Inhalts. Vol. 1.5 vols. Studien zur Palaeographie und Papyruskunde 9. Leipzig: Verlag H. Haessel Nachfolger. 1911. Griechische und koptische Texte theologischen Inhalts. Vol. 2. 5 vols. Studien zur 
Palaeographie und Papyruskunde 11. Leipzig: Verlag H. Haessel Nachfolger.

1912. Griechische und koptische Texte theologischen Inhalts. Vol. 3. 5 vols. Studien zur

Palaeographie und Papyruskunde 12. Leipzig: Verlag H. Haessel Nachfolger.

1914. Griechische und koptische Texte theologischen Inhalts. Vol. 4. 5 vols. Studien zur

Palaeographie und Papyruskunde 15. Leipzig: Verlag H. Haessel Nachfolger.

. 1917. Griechische und koptische Texte theologischen Inhalts. Vol. 5.5 vols. Studien zur

Palaeographie und Papyruskunde 18. Leipzig: Verlag H. Haessel Nachfolger.

Wiesmann, Hermann. 1931. Sinuthii Archimandritae Vita et Opera Omnia III. Corpus Scriptorum

Christianorum Orientalium 96, Scriptores Coptici 8. Paris: Peeters.

1936. Sinuthii Archimandritae Vita et Opera Omnia IV. Corpus Scriptorum Christianorum

Orientalium 108, Scriptores Coptici 12. Paris: Peeters.

—. 1951. Sinuthii Vita Bohairice. Corpus Scriptorum Christianorum Orientalium 129, Scriptores

Coptici 16. Paris: Peeters.

Wilson, William. 1886. "Excerpts of Theodotus; Or, Selections from the Prophetic Scriptures.” In The Ante-Nicene Fathers, Vol. 8: Fathers of the Third and Fourth Centuries: The Twelve Patriarchs, Excerpts and Epistles, the Clementina, Apocrypha, Decretals, Memoirs of Edessa and Syriac Documents, Remains of the First Ages, edited by Alexander Roberts and James Donaldson, 4350. Buffalo, NY: Christian Literature Company.

Wissa, Abba. 2015. The Life of St Shenouda: Translation of the Arabic Life. Sydney: St. Shenouda Press.

Worrell, William H. 1923. The Coptic Manuscripts in the Freer Collection. University of Michigan 
Studies, Humanistic Series 10. New York and London: Macmillan.

- 1945. A Short Account of the Copts. Ann Arbor, Michigan: University of Michigan Press.

Young, Dwight W. 2000. With Respect to the Fourth Work of Shenute's Sixth Canon. Göttinger Miszellen 179: 85-106.

—. 2002. “Two Unplaced Fragments from a Copy of Shenute’s Sixth Canon.” Göttinger Miszellen 189: 99-110.

Young, Frances. 1997. Biblical Exegesis and the Formation of Christian Culture. Cambridge: Cambridge University Press.

Zanetti, Ugo. 2008. "Liturgy in the White Monastery." In Christianity and Monasticism in Upper Egypt, edited by Gawdat Gabra and Hany N. Takla, 201-10. Cairo: The American University in Cairo Press.

Zeldes, Amir. 2018. Multilayer Corpus Studies. Routledge Advances in Corpus Linguistics 22. London: Routledge.

Zeldes, Amir, Julia Ritz, Anke Lüdeling, and Christian Chiarcos. 2009. “ANNIS: A Search Tool for Multi-Layer Annotated Corpora." In Proceedings of Corpus Linguistics 2009, accessed December 5, 2021, http://ucrel.lancs.ac.uk/publications/cl2009/.

Zeldes, Amir, and Caroline T. Schroeder. 2015. "Computational Methods for Coptic: Developing and Using Part-of-Speech Tagging for Digital Scholarship in the Humanities.” Digital Scholarship in the Humanities 30 (Supplement 1): i164-76.

. 2016a. "An NLP Pipeline for Coptic." In Proceedings of the 10th SIGHUM Workshop on Language Technology for Cultural Heritage, Social Sciences, and Humanities, edited by Nils 
Reiter, Beatrice Alex, and Kalliopi A. Zervanou. 146-55. Berlin: Association for Computational Linguistics.

2016b. “SCRIPTORIUM Part-of-Speech Tagsets for Sahidic Coptic.” Accessed September 12, 2021, http://copticscriptorium.org/download/tools/scriptorium_tagset_documentation.pdf.

Zeman, Daniel. 2008. "Reusable Tagset Conversion Using Tagset Drivers.” In Proceedings of the Sixth International Conference on Language Resources and Evaluation (LREC'08), edited by Nicoletta Calzolari, Khalid Choukri, Bente Maegaard, Joseph Mariani, Jan Odijk, Stelios Piperidis, and Daniel Tapias. 213-18. Marrakech: European Language Resources Association. Zhang, Shuo, and Amir Zeldes. 2017. “GitDOX: A Linked Version Controlled Online XML Editor for Manuscript Transcription." In Proceedings of FLAIRS: Special Track on Natural Language Processing of Ancient and Other Low-Resource Languages, Marco Island, Florida, edited by Vasile Rus and Zdravko Markov, 619-23. Palo Alto, California: The AAAI Press.

Zoega, Georg. 1810. Catalogus Codicum Copticorum Manuscriptorum qui in Museo Borgiano Velitris Adservantur. Rome: Sacra Congregatio de Propaganda Fide. 